\title{
INEL Integrated Spent Nuclear Fuel Consolidation Task Team Report
}

R. N. Henry, J. H. Clark, N. A. Chipman, R. C. Schmitt, R. E. Cottam, M. L. Russell, N. J. Hatfield, R. K. Elwood, R. J. Freeman, R. L. Park, K. A. Robb, A. L. Ayers, D. V. Toomer

September 1994

(2) Westinghouse Idaho

PREPARED FOR THE

DEPARTMENT OF ENERGY

IDAHO OPERATIONS OFFICE

UNDER CONTRACT DE-AC07-84ID12435 


\section{DISCLAIMER}

This report was.prepared as an account of work sponsored by an agency of the United States Government. Neither the United States Government nor any agency thereof, nor any of their employees, make any warranty, express or implied, or assumes any legal liability or responsibility for the accuracy, completeness, or usefulness of any information, apparatus, product, or process disclosed, or represents that its use would not infringe privately owned rights. Reference herein to any specific commercial product, process, or service by trade name, trademark, manufacturer, or otherwise does not necessarily constitute or imply its endorsement, recommendation, or favoring by the United States Government or any agency thereof. The views and opinions of authors expressed herein do not necessarily state or reflect those of the United States Government or any agency thereof. 


\section{DISCLAIMER}

Portions of this document may be illegible in electronic image products. Images are produced from the best available original document. 


\begin{abstract}
This document describes a draft plan and schedule to consolidate spent nuclear fuel (SNF) and special nuclear material (SNM) from aging storage facilities throughout the Idaho National Engineering Laboratory (INEL) to the Idaho Chemical Processing Plant (ICPP) in a safe, cost-effective, and expedient manner. A fully integrated and resource-loaded schedule was developed to achieve consolidation as soon as possible. A1l of the INEL SNF and SNM management tasks, projects, and related activities from fiscal year 1994 to the end of the consolidation period are logic-tied and integrated with each other. The schedule and plan are presented to initiate discussion of their implementation, which is expected to generate alternate stakeholder concepts that can be evaluated using the methodology described in this report. Three perturbations to consolidating SNF as soon as possible are also explored. If the schedule is executed as proposed, the new and on-going consolidation activities will require about 6 years to complete and about $\$ 25.3 \mathrm{M}$ of additional funding. Reduced annual operating costs are expected to recover the additional investment in about 6.4 years. The total consolidation program as proposed will cost about $\$ 66.8 \mathrm{M}$ and require about 6 years to recover via reduced operating costs from retired SNF/SNM storage facilities. Detailed schedules and cost estimates for the Test Reactor Area Materials Test Reactor canal transfers are included as an example of the level of detail that is typical of the entire schedule (see Appendix D). The remaining work packages for each of the INEL SNF consolidation transfers are summarized in this document. Detailed cost and resource information is available upon request for any of the SNF consolidation transfers.
\end{abstract}


. 


\section{EXECUTIVE SUMMARY}

Spent nuclear fuel (SNF) has been stored and processed at the Idaho National Engineering Laboratory (INEL) from onsite reactors, facilities across the country, and even foreign research reactors. Currently SNF is stored in various configurations at six different INEL facilities. Special Nuclear Material (SNM) has been used to support research and development of INEL missions and has also been received from offsite facilities for storage at the INEL. SNM is stored at four different INEL facility locations. Post cold war events, and related materials management decisions, have prompted the need to consolidate these storage activities to enhance safety and reduce operating costs. Thus, a multi-contractor INEL task team was formed to develop a predecisional draft INEL SNF/SNM consolidation plan. Knowledgeable and experienced INEL personnel provided the detail and insight necessary to scope and understand the issues, and develop the intricate planning strategy.

This report describes the development of the INEL SNF consolidation plan. It also presents a fully integrated and resource-loaded schedule to implement SNF/SNM consolidation as soon as possible at the Idaho Chemical Processing Plant (ICPP), in a safe and cost-effective manner. The plan integrates a 11 SNF shipper and receiver management activities. Integration ensures the required resources have been identified, are available when needed, and dependent activities are Tinked together.

The scope of this plan includes: (a) SNF and/or SNM consolidation transfers from the Test Reactor Area, Test Area North, and Power Burst Facility;

(b) SNF consolidation transfers within ICPP; (c) continued SNF receipts and shipments at ICPP, for example, Navy; and (d) related SNF activities, e.g., CPP-666 Fuel Storage Area reracking project. SNM consolidation transfers from Argonne National Laboratory-West and the Radioactive Waste Management Complex were not included in the scope of this study and are not scheduled in this plan.

Although the plan presents a potential integrated schedule, no SNF consolidation strategy has been finalized or adopted by the U.S. Department of Energy (DOE). Thus, the $\mathrm{plan}$ provides the basis to initiate discussion with concerned stakeholders. This involvement will help ensure that a complete scope of issues and strategic solutions are considered before selecting a particular SNF management action.

Assessing the advantages and disadvantages of atternate strategies requires accurate and detailed understanding of intricate and inter-related planning issues. This level of detailed planning required knowledgeable personnel and a significant amount of time, but ensured a comprehensive, systems analys is approach. The $\mathrm{plan}$ 's modular organization allows assessment of the impacts of adding or deleting SNF transfers, new schedule deadlines, or evaluation tradeoff issues related to cost and resource management.

Open $\mathrm{P} 7 \mathrm{an}{ }^{\mathrm{T}}$ software was used to manage and integrate the extensive $\mathrm{planning}$ information. This tool supported the timely evaluation of a very complicated schedule: A printed copy of the complete schedule (about 2,000 pages) is 
available and includes more than 6,000 tasks, 8,000 logic-ties, and 26,100 resource calls. This amount of information is necessary to assess the planning issues, but it is not "user friendly" until summarized. Thus, the schedule is supplemented by this report. This report (1) describes the assumptions and strategies that were used to develop the $\mathrm{pl}$ an and schedule, (2) summarizes the costs, resources, and schedules, (3) identifies the key critical path issues for the as soon as possible base case, and (4) evaluates the impacts of some possible perturbations to the base case.

If the initial plan proves to address all concerns adequately, and it is implemented as presented, it wi17:

(1) Resolve the remaining INEL environmental, safety, and health (ES\&H) vulnerability assessment issues identified in the Phase II, Plan of Action to Resolve Spent Nuclear Fuel Vulnerabilities by retiring six INEL SNF/SNM storage facilities,

-(2) Reduce safety risks for SNF and SNM storage by relocating these inventories to newer and safer INEL facilities,

(3) Reduce long-term operational costs,

(4) Continue to demonstrate national leadership in SNF and SNM storage via continued rapid response to ES\&H issues, timely implementation of new dry storage demonstration programs, and overal1 cost-effective operations, and

(5) Demonstrate the INEL's ability to work effectively as an integrated team, and provide technology transfer to the commercial SNF programs by means of dry storage data for new fuel types and SNF in degraded condition.

The key planning strategy for implementing INEL SNF consolidation is use of existing dry storage space at ICPP, and new construction for Three Mile Island SNF from Test Area North. Other initiating strategies include minimizing transfers to busy ICPP storage areas, developing standardized can sizes for repackaged SNF, using a common transfer cask for SNF transfer to the Irradiated Fuel Storage Facility (IFSF), and minimizing the total number of transfers by moving SNF directly to its preferred interim storage mode (dry storage).

INEL SNF/SNM consolidation costs are identified in Table EX-1. These costs do not include any contingency or management reserve and are in constant 1994 dollars. Activities that are not funded are highlighted by shadowed boxes in Table EX-1. About $\$ 25.3 \mathrm{M}$ of new funding is needed to fund the remaining SNF consolidation transfers. The total consolidation program will require about 6 years to implement. Total cost for the entire INEL SNF consolidation program is estimated at $\$ 66.8 \mathrm{M}$. The cost recovery time for the consolidation program as a whole is estimated to be 6 years. Individual recovery times for each storage area are also indicated in Table EX-1.

Critical path items that must be funded in late fiscal year 1994, or very early fiscal year 1995, to support the as soon as possible base case include: (1) inspection and preparation of the Thermal Fuel Behavior Program \#2 (TFBP-2) cask, (2) design and fabrication of an adapter plate for the IFSF 
Table EX-1 INEL SNF Consolldation Costs Summary

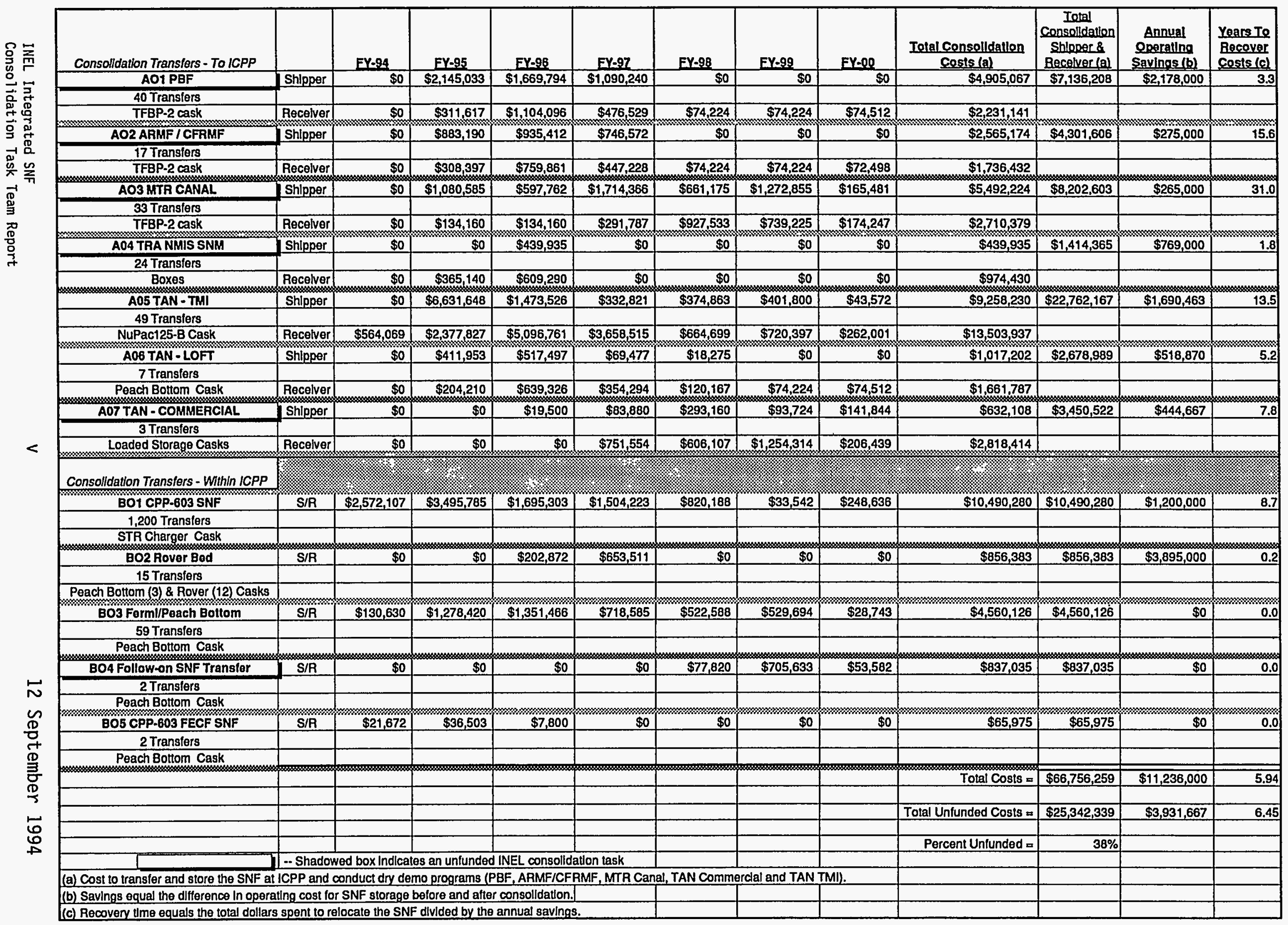


transfer cart, and (3) design, fabrication, and checkout of a prototype canister using the TFBP-2 cask as a top loader.

The impacts of delayed funding, safety drivers, and tighter schedule interfaces with the IFSF were also evaluated. Table EX-2 summarizes the cost and schedule impacts for those SNF transfers where there were changes. The cost for the remaining INEL SNF consolidation activities stay the same. A one year funding delay for the SNF transfers from Power Burst Facility, Materials Test Reactor canal, and ARMF/CFRMF (Case A) will increase the total cost of the INEL SNF consolidation program by about $\$ 3.5 \mathrm{M}$. Conducting parallei transfers to IFSF from the CPP-603 south basin and the consolidation program (Case C) will increase the cost by about $\$ 5.0 \mathrm{M}$.

Table EX-2. Cost and Schedule Impacts of (A) Funding Delays, (B) Safety Drivers, and (C) Tighter Schedule Interfaces

\begin{tabular}{|l|c|c|c|}
\hline & CASE A & CASE B & CASE C \\
\hline & $\begin{array}{l}\text { Funding Delayed One } \\
\text { Year (MTR Cana7, } \\
\text { ARMF/CFRMF, \& PBF) }\end{array}$ & $\begin{array}{l}\text { Safety Driver (MTR } \\
\text { Canal Funded in FY-95; } \\
\text { PBF \& ARMF/CFRMF in } \\
\text { FY-96) }\end{array}$ & $\begin{array}{l}\text { Schedule Constraints, } \\
\text { Closed Transfer } \\
\text { Window (Parallel SNF } \\
\text { Transfers to IFSF) }\end{array}$ \\
\hline $\begin{array}{l}\text { Increased } \\
\text { Operational Costs }\end{array}$ & $\$ 2,830,583$ & $\$ 1,226,500$ & $\$ 2,844,417$ \\
\hline $\begin{array}{l}\text { Increased SNF } \\
\text { Transfer Costs }\end{array}$ & $\$ 665,000$ & $\$ 0$ & $\$ 2,156,000$ \\
\hline Total Cost & $\$ 3,495,583$ & $\$ 1,226,500$ & $\$ 5,000,417$ \\
\hline
\end{tabular}


A task team, represented by principal INEL contractors, initiated work on the feasibility of SNF consolidation in the fall of 1992 . This work began as an effort to resolve certain issues identified in the first draft of the Idaho National Engineering Laboratory (INEL) Spent Fuel Roadmap. As a result of this effort, WIN-367, Interim Report of the INEL Spent Nuclear Fuel Consolidation Task Team was issued. A principal conclusion from WIN-367 was that consolidation of INEL SNF was feasible and that preliminary actions could be initiated to reduce long-term operating costs and risks. However, further analyses were needed to confirm this conclusion, and to provide a methodology that could be used to determine the best transition strategy for the INEL.

A DOE report, Spent Fuel Working Group Report on Inventory and Storage of the Department's Spent Nuclear Fue 7 and Other Reactor Irradiated Nuclear Materials and Their Environmental, Safety, and Health Vulnerabilities, independently verified INEL safety concerns. This report further added urgency for developing detailed plans that could be used to implement the proposed SNF consolidation strategy. Thus, a second task team was formed in January 1994 to develop: (1) an INEL SNF and SNM consolidation plan, (2) a detailed and fully integrated consolidation schedule, and (3) additional analyses including operational risks, resource requirements, funding profiles, and prioritized fuel transfers. This report documents the task team's efforts. 


\section{CONTENTS}

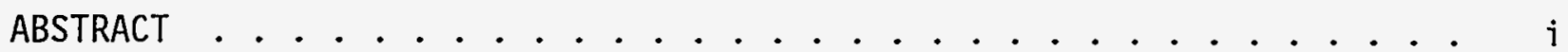

EXECUTIVE SUMMARY ....................... i i

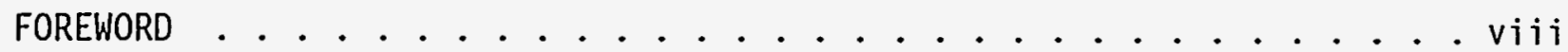

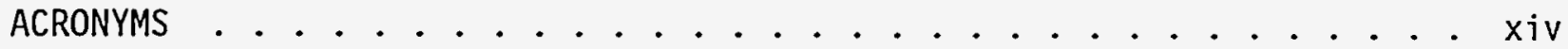

1.0 INTRODUCTION . . . . . . . . . . . . . . . . . . 1

1.1 TASK TEAM MISSION . . . . . . . . . . . 2

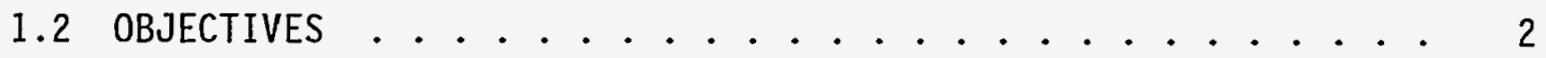

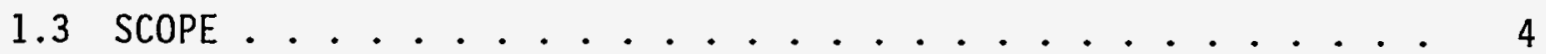

1.3.1 SNF Consolidation Complexities ......... 5

1.3.2 Work Breakdown Structure . . . . . . . . . . 6

1.4 PRINCIPAL INEL CONSOLIDATION ACTIVITIES ......... 6

1.5 SNF CONSOLIDATION ORGANIZATION ALTERNATIVES ........ 11

2.0 CONSOLIDATION STRATEGY . . . . . . . . . . . . 13

2.1 PRINCIPAL JUSTIFICATIONS . . . . . . . . . . 13

2.2 CONSOLIDATION GOALS ......................... 13

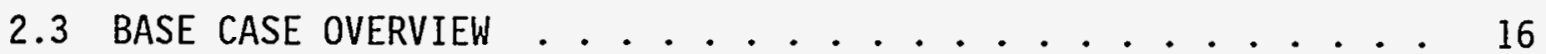

2.4 TECHNICAL TASK EXAMPLE (TRA MTR CANAL SNF CHARACTERIZATION, REPACKAGING, AND TRANSFER TO IFSF) . . . . . . . 18

2.4.1 Overview of SNF Transfers from the MTR Canal . . . . 18

2.4.2 Development of Detailed Schedule and Cost Information . 21

2.5 PRIORITIZATION METHODOLOGY for SNF/SNM CONSOLIDATION TRANSFERS 34

3.0 PROPOSED CONSOLIDATION SCHEDULE . . . . . . . . 37

3.1 BASE CASE ............................ 37

3.2 PERTURBATIONS OF THE BASE CASE ............ 43

3.2 .1 Case A--Funding Delays . . . . . . . . . 43

3.2.2 Case B--Safety Drivers . . . . . . . . . . 47

3.2.3 Case C--Tighter ScheduTe Constraints/Closed Transfer Window .............. . . 4 47 
4.0 KEY RESOURCE REQUIREMENTS . . . . . . . . . . . . 49

4.1 INEL FACILITY REQUIREMENTS . . . . . . . . . . . . 49

4.1 .1 IFSF . . . . . . . . . . . . . . 49

$4.1 .2 \quad \mathrm{CPP}-749 \ldots \ldots \ldots \ldots \ldots 53$

4.1 .3 CPP-666 Fuel Storage Area . . . . . . . . . 53

4.1.4 CPP-651 Unirradiated Fuel Storage Facility...... 54

4.1 .5 New Facilities for TAN SNF . . . . . . . . 54

4.2 INEL ROADS AND EQUIPMENT REQUIREMENTS .......... 57

4.2.1 INEL Roads and Bridges . . . . . . . . . 57

4.2.2 Description of Casks .............. 57

4.2.2.1 TRA Hot Cells Carrier ......... . 57

4.2.2.2 Thermal Fue1 Behavior Program Cask Number 2 (TFBP-2) ................ 57

4.2.2.3 Peach Bottom Cask Number 2 . . . . . . 60

4.2.2.4 NuPac 125-B .............. 60

4.2.2.5 Dry Commercial Spent Nuclear Fuel Casks ..... . 64

4.2.2.6 TN-8L Spent Fuel Shipping Cask ........ 65

4.3 PERSONNEL AND TRAINING REQUIREMENTS ........... 65

4.4 DOCUMENTATION REQUIREMENTS ................ 65

4.4.1 Transportation ................. 65

4.4 .2 NEPA ........................ 71

4.4 .3 Safety Analyses ............. 71

4.5 FUNDING PROFILES . . . . . . . . . . . . . . . 72

4.6 RESOURCE CONSERVATION ...................... 73

5.0 INEL SNF CONSOLIDATION ISSUES AND RISKS . . . . . . . 75

5.1 TECHNICAL RISKS . . . . . . . . . . . . 75

5.2 MANAGEMENT RISKS ...................... 75

5.3 OTHER POTENTIAL CONSOLIDATION INVENTORIES ........ 75

5.3.1 INEL Radioactive Waste Management Complex (RWMC) U-233 . 75

5.3.2 0ak Ridge Y-12 P1ant U-233 . . . . . . . . 78

5.3 .3 INEL ICPP U-233 .................... 78

5.3 .4 ATR SNF TRANSFERS FOR CORROSION STUDIES . . . . . . 79 
6.0 REMAINING CONCERNS AND ISSUES, AND POTENTIAL RESOLUTIONS . . . . 81

6.1 CRITICAL PATH ISSUES ................... 81

6.2 SCHEDULE OWNERSHIP AND MAINTENANCE .......... 81

REFERENCES ............................ 82

Appendix A PROPOSED SNF CONSOLIDATION INVENTORY .......... A-1

Appendix B TASK TEAM MEMBERSHIP AND RESPONSIBILITIES . ....... $\ldots$ B- 1

Appendix $C$ PLAN ASSUMPTIONS ....................

AppendiX D SCHEDULES AND COST ACCOUNT PLANS .......... . . .

Appendix E SNF or SNM TRANSFERS TECHNICAL TASKS .......... E-1

E.1 PBF Canal SNF Transfer To ICPP IFSF . . . . . . . . E-1

E.2 TRA ARMF/CFRMF SNF Transfer To ICPP IFSF ........ E-5

E.3 TRA MTR Canal SNF Characterization, Repackaging, and Transfer to IFSF ..................... . . . . . . . .

E.4 TRA NMIS SNM Transfer to CPP-651 .......... . . E-8

E.5 TAN TMI SNF Transfer To A New Facility at ICPP ....... E-10

E.6 TAN LOFT SNF Transfer To CPP-749 . . . . . . . . . . E-12

E.7 TAN Commercial SNF Transfer to New Pad at ICPP . . . . . . E-13

\section{FIGURES}

Figure 1.0-1 INEL SNF Storage Locations ........... 3

Figure 1.3-1 INEL Integrated SNF Consolidation WBS ....... 7

Figure 1.3-2 A WBS Example of the Level of Detail Collected and Analyzed .............. . . 8

Figure 1.4-1 INEL Long-term Integrated Spent FueT Program PTan . . 12

Figure 2.1-1 Consolidation of INEL SNF Storage Facilities . . . . . 14

Figure 2.3-1 Overview of INEL SNF Consolidation Transfers to ICPP . . 17

Figure 2.3-2 Overview of Fue T Transfer Scenarios ........ 19

Figure 2.4-1 MTR canal was used as part of the test train assembly

facility for underwater handling of irradiated components. ............... 20

Figure 3.0-1 SNF/SNM Consolidation Schedule ......... 38

Figure 3.1-1 Base Case - IFSF SNF Consolidation Activities . . . 39 
FIGURES (Continued)

Figure 3.1-2 Cost Profiles for INEL SNF Consolidation Base Case (Funded vs. Unfunded) . . . . . . . . 42

Figure 3.2-1 Case A - Funding Delayed One Year (FY-96) . . . . . . 44

Figure 3.2-2 Case B - Safety Drivers (MTR Canal, Cask, Maintenance, IFSF Transfer Cart) . . . . . . . . . 45

Figure 3.2-3 Case C - Schedule Constraints/Closed Transfer Window . . 46

Figure 4.1-1 Cutaway of IFSF ............ 51

Figure 4.1-2 Layout of CPP-749 ............ . 52

Figure 4.1-3 Layout of CPP-651 ........... . . 55

Figure 4.1-4 Conceptual Design for TMI Above Ground Vault Structure . 56

Figure 4.2-1 TRA Hot Cells Carrier . . . . . . . . . 58

Figure 4.2-2 TFBP-2 Cask Transport System Major Components . . . . . 59

Figure 4.2-3 Peach Bottom Cask ............ 61

Figure 4.2-4 Assembled NuPac 125-B .......... 62

Figure 4.2-5 Major Components of the NuPac 125-B ....... 63

Figure 4.2-6 Cross-Section of the TN-8L Shipping Cask ...... 66

Figure 4.3-1 Fuel Handling Operators Annual Manpower Requirements . . 67

Figure 4.3-2 Fuel Handling Supervision Annual Manpower Requirements . 68

Figure 4.3-3 Fuel Storage Support Engineers Annual Manpower

Requirements ........... . 69

Figure 4.3-4 Health Physicists Support - Annual Manpower

Requirements ........... . 70

Figure 1.0-1 INEL SNF Storage Locations .......... A-3

Figure B-1 INEL Integrated SNF Consolidation Task Team

Organization .............. B- B-2

Figure B-2 INEL SNF Consolidation Task Team Overall Participation B-3

Figure E-1 Top View of PBF Reactor Vessel and Canal . . . . . E-2

Figure E-2 TFBP-2 Cask and Transporter Ready for Transfer at PBF . E-3

Figure E-3 A Crane Removes The Fully Assembled TFBP-2 Cask From The Transporter ............ . . E-4

Figure E-4 Layout of ARMF and CFRMF Building ....... E-6

Figure E-5 General Arrangement of ARMF Reactor Structure . . . . E-7

Figure E-6 TRA-621 NMIS Floor PTan .......... . E-9 
FIGURES (Continued)

Figure $\mathrm{E}-7$

Table EX-1.

Table EX-2.
TAN-607 Facilities . . . . . . . . . . E-11 INEL SNF Consolidation Costs Summary . . . . . . v Cost and Schedule Impacts of (A) Funding Delays, (B) Safety Drivers, and (C) Tighter Schedule Interfaces . . vi

\section{TABLES}

Table 1.4-1 INEL SNF/SNM Consolidation Transfers To ICPP . . . . 9

Table 1.4-2 SNF Consolidation Transfers Within ICPP ...... . 9

Table 1.4-3 SNF/SNM Transfers To And From The ICPP ....... 9

Table 1.4-4 Related SNF Activities At INEL .......... 10

Table 1.4-5 Related Activities That Are Independent of SNF Consolidation ................. 10

Table 2.4-1

Table 2.4-2 Table 2.4-3 Table 2.4-4 Table 2.4-5

Table 2.4-6

Table 2.4-7

Table 2.4-8

Table 2.4-9

Table 2.4-10

Table 2.4-11

Table 2.4-12

Table 3.1-1

Table 3.2-1

Table 4.1-1

Table 5.1-1

WBS A03 - TRA MTR Canal SNF Characterization, Repackaging, and Transfer to ICPP IFSF . . . . . 22 WBS A01 - PBF Canal SNF Transfer to ICPP IFSF . . . 23 WBS A02 - TRA ARMF/CFRMF SNF Transfer to ICPP IFSF . . . 24 WBS A04 - TRA NMIS SNM Transfer to CPP-651 . . . . 25 WBS A05 - TAN TMI SNF Transfer to New Facility at ICPP . 26 WBS A06 - TAN LOFT SNF Transfer to CPP-749 . . . . 27 WBS A07 - TAN Commercial SNF Transfer to New Pad at ICPP . . . . . . . . . . . . . 28 WBS B01 - CPP-603 SNF Repacking and Transfer to CPP-666 29 WBS B02 - Rover-Bed Material Repackaging and Transfer to CPP-749 .................. 30 WBS B03 - Fermi and Peach Bottom SNF Repackaging and Transfers ............... . 31 WBS B04 - Follow-on Transfers of Consolidation Fuels . . 32 WBS B05 - CPP-603 FECF-SNF Repackaging and Transfer to IFSF ................... 33 INEL Consolidation Costs Summary . . . . . . . 41 Additional Costs of Perturbation Cases . . . . . . 47 Dry SNF Storage Requirements . . . . . . . 50 INEL SNF Consolidation Issues and Risks . . . . . 76 
ACRONYMS

ALARA as-low-as-reasonably achievable

ANL-W Argonne National Laboratory-West

ARMF Advanced Reactivity Measurement Facility

ATR Advanced Test Reactor

CADMOST FueT Canning and Dry Modular Storage

CFA Central Facility Area

CFRMF Coupled Fast Reactivity Measurement Facility

CSE Criticality Safety Evaluation

cX categorical exclusion

D\&D decontamination and decommissioning

DOE U.S. Department of Energy

DOE-ID U.S. Department of Energy-Idaho Operations Office

DOT U.S. Department of Transportation

EA environmental assessment

EG\&G EG\&G Idaho, Inc.

EIS environmental impact statement

EM DOE Office of Environmental Management

ER\&WM Environmental Restoration and Waste Management

ES\&H environmental, safety, and health

ETR Engineering Test Reactor

FECF Fuel Element Cutting Facility

FONSI Finding of No Significant Impact
FSAR Final Safety Analysis Report

FSV Fort St. Vrain

FHU fuel handling unit

FY fiscal year

GETR General Electric Test Reactor

HP health physicist

ICPP Idaho Chemical Processing Plant

IFSF Irradiated Fuel Storage Facility

INEL Idaho National Engineering Laboratory

K thousand

LICP Line Item Construction Project

LOFT Loss-of-Fluid Test

M million

M\&O management and operations

MTHM metric tons heavy metal

MTR Materials Test Reactor

NA not applicable

NE DOE Office of Nuclear Energy

NEPA National Environmental Policy Act

NMIS Nuclear Material Inspection \& Storage

NRC Nuclear Regulatory Commission

NRF Nava7 Reactor Facility

NuPac Nuclear Packaging Cask 


\section{ACRONYMS (Continued)}

ORR Operational Readiness Review

PB-2 Peach Bottom-2

PBF Power Burst Facility

PSAR Preliminary Safety Analysis Report

RA Readiness Assessment

ROD Record of Decision

RW DOE Office of Radioactive Waste

RWMC Radioactive Waste Management

Complex

SAR Safety Analysis Report

SNF spent nuclear fuel

SNM special nuclear material

So system operations

TAN Test Area North

TBD to be determined

TFBP Thermal Fuel Behavior Program

TMI Three Mile Island

TRA Test Reactor Area

TS/S Technical Specifications and Standards

TSR Technical Safety Requirements

TTR - Thermal Test Reactor

U-233 Uranium-233

WBS work breakdown structure

WE-2 White Elephant \#2
WINCO Westinghouse Idaho Nuclear Company, Inc. 


\subsection{INTRODUCTION}

The Idaho National Engineering Laboratory (INEL) is one of the U.S. Department of Energy's (DOE) largest national laboratories. Established in 1949 as the National Reactor Testing Station, it has been the site of the largest concentration of nuclear reactors (52) in the world. Most of the reactors were phased out after fulfilling their research mission, but several are still operating. This unique national role has allowed the INEL to develop core competencies in (1) nuclear reactor development, testing, and operation, (2) spent nuclear fuel (SNF) management (storage and processing), and (3) first of a kind waste processing development and related waste management activities. The INEL has developed the most diversified reactor operations, and the newest and most diversified SNF storage and processing center in the nation.

A task team, represented by principal INEL contractors, initiated work on the feasibility of SNF consolidation in the fall of 1992. This work began as an effort to resolve certain issues identified in the first draft of the INEL Spent Fuel Roadmap. As a result of this effort, Interim Report of the INEL Spent Nuclear Fuel Consolidation Task Team, WIN-367, was issued. A principal conclusion from WIN-367 was that consolidation of INEL SNF was feasible, and that preliminary actions could be initiated to reduce long-term operating costs and risks. However, the development of a detailed analytical model was necessary to confirm this conclusion and evaluate alternate SNF management strategies for the INEL.

The Spent Fuel Working Group Report on Inventory and Storage of the Department's Spent Nuclear Fuel and Other Reactor Irradiated Nuclear Materials and Their Environmental, Safety, and Health Vulnerabilities independently verified INEL safety concerns. The report further added urgency for developing detailed plans that could be used to implement the proposed SNF consolidation strategy. Thus, a second task team was formed to: (1) develop a consolidation plan that included resource requirements, funding profiles, prioritized SNF transfers, and operational risk evaluation and, (2) develop a detailed and fully integrated INEL SNF consolidation schedule.

Because of the 1 arge number of reactors that have operated at the INEL, many different types of SNF have been stored and reprocessed. Reprocessing SNF recycled unused uranium and other wanted byproducts. It also helped prepare the separated waste materials for disposal. SNF inventory data is stored at INEL in a database system. The database includes detailed descriptions of the fissile material amounts and storage locations. This draft SNF consolidation plan addresses those fuels specifically proposed for transfer to the Idaho Chemical Processing Plant (ICPP) for consolidation of the INEL SNF inventory. The plan also includes the SNF transfers at the ICPP that interface and must be prioritized with the INEL transfers. A 1isting of the INEL SNF proposed for transfer is located in Appendix A.

"Generally speaking, SNF consists of unreacted source and fissile material, for example, Uranium-238 and Uranium-235; transuranic elements; fission products (high-level waste); fission product encapsulation (cladding); and structural components. 
SNF is in various types of storage configurations at several different INEL facilities including: Power Burst Facility (PBF), Test Reactor Area (TRA), Test Area North (TAN), ICPP, Argonne National Laboratory-West (ANL-W), and Naval Reactor Facility (NRF). Figure 1.0-1 shows the location of these facilities. Because of the diverse nature of the storage configurations, the types of SNF, and the recent decision to terminate reprocessing at the ICPP, new SNF programmatic direction is being evaluated. The DOE Programmatic Spent Nuclear Fuel and Idaho National Engineering Laboratory Environmental Restoration and Waste Management Programs Environmental Impact Statement (Programmatic SNF and INEL ER\&WM EIS) will be used to consider alternatives for managing the nation's SNF.

Obviously, the INEL SNF must continue to be managed safely during this National Environmental Policy Act (NEPA) process. The activities proposed in this plan are enveloped by each alternative under consideration in the Programmatic SNF and INEL ER\&WM EIS. A7though INEL SNF consolidation has not been adopted by DOE, this report presents the cost, resources, and potential schedule that would lead to timely completion of these objectives. When finalized, this proposed SNF consolidation plan will ensure near-term environmental, safety, and health (E\&SH) issues are resolved in a timely and cost-effective manner, while decisions are made concerning the INEL's future SNF management role.

This potential SNF consolidation plan considers all of the INEL SNF and special nuclear material (SNM) management tasks and activities from fiscal year (FY)-94 to the end of the consolidation period. If the schedule is executed as proposed, consolidation will require about 6 years to complete. Consolidation is considered complete when alT SNF and SNM has been transferred to the ICPP and placed in its designated location.

Should DOE choose to follow this plan, discussions with concerned stakeholders may be pursued. The feedback from this process would be used to formulate final action by DOE-Idaho Operations office (DOE-ID) to implement the plan, or some new modified version of the plan.

\subsection{TASK TEAM MISSION}

The purpose of the INEL Integrated SNF Consolidation Task Team was to provide DOE-ID with a fully integrated and resource-loaded draft plan. The scope of the plan is to consolidate INEL SNF and SNM at the ICPP as soon as possible, in a safe and cost-effective manner. Developing the plan and detailed supporting schedule is a necessary first step towards analyzing new a) ternatives and identifying an optimum planning strategy for the future.

\subsection{OBJECTIVES}

An INEL SNF consolidation plan that addressed high-level feasibility issues was urgently needed. Development of such a plan required a detailed analysis and integration of all of the INEL SNF management activities. Dependent tasks 


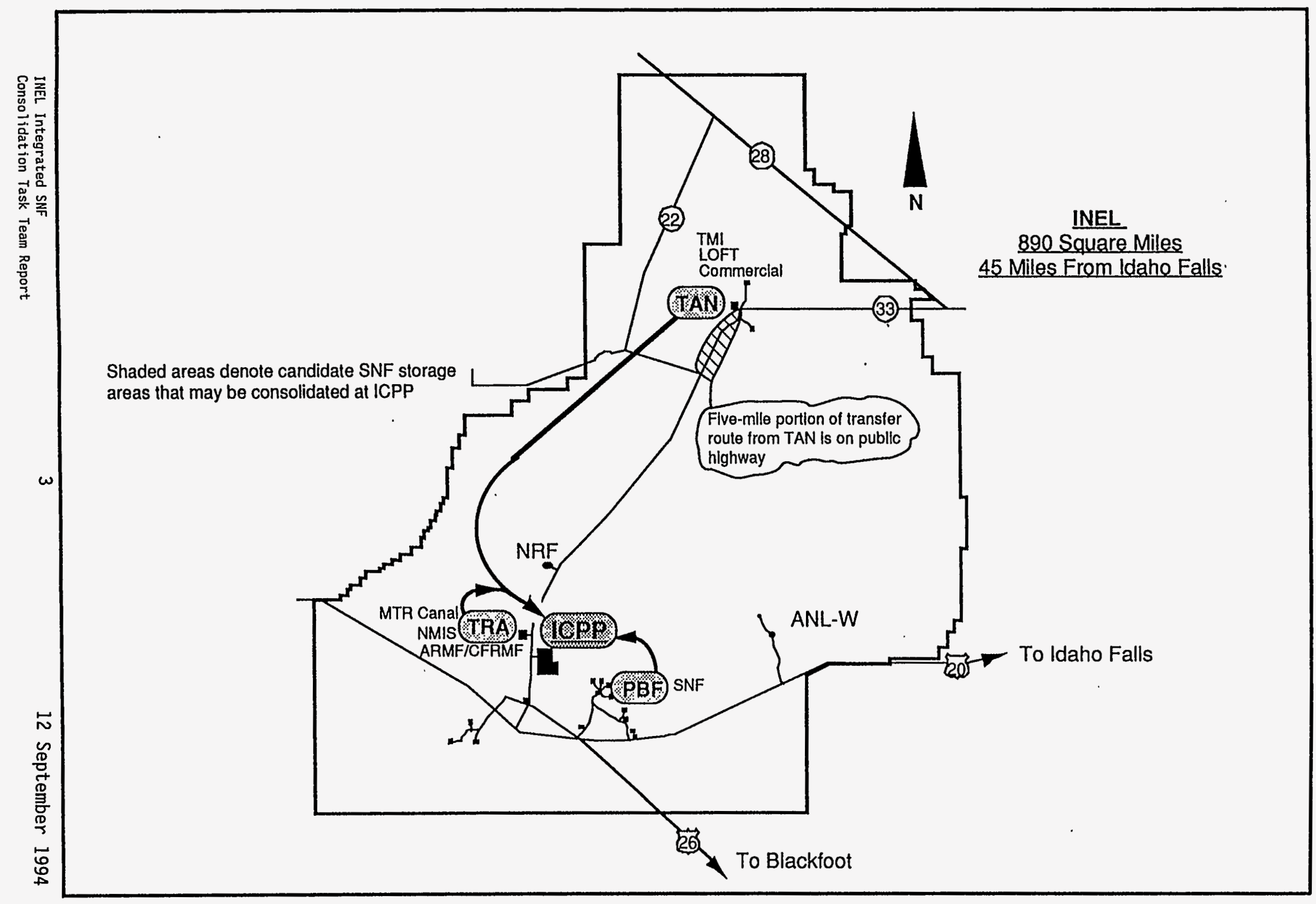

Figure 1.0 - 1 INEL SNF/SNM Storage Locations And Consolidation Transfers 
were identified and logic-tied to one another. With this in mind, the following objectives were identified and completed.

1. Form a multi-discipline INEL-wide task team to produce the plan (see Appendix B).

2. Develop a list of assumptions to bound the scope of the plan (see Appendix C).

3. Develop a "working" inventory of INEL SNF (see Appendix A). A working inventory includes a 11 of the SNF and SNM that is scheduled to be shipped to the ICPP during this consolidation period.

4. Identify the anticipated Tifetimes for INEL SNF and SNM storage facilities as related to the consolidation program lifetime (see WIN-367).

5. Identify all INEL key resource requirements including fuel handling and transportation resources and issues [i.e., equipment, casks, permits, safety documentation, NEPA documentation, personnel, fuel handling tools, training, procedures, Operational Readiness Reviews, canning stations, SNF characterization/inspection requirements, etc.] (see section 4.0 ).

6. Develop individual schedules and cost account plans for candidate fuel or material transfers to ICPP storage facilities (see Appendix D for the detailed MTR canal SNF transfer package).

7. Combine the individual schedules into an overalT, integrated INEL SNF consolidation schedule. The schedule achieves consolidation as soon as possible based on the optimum selection of funding, timing, safety risks, environmental impacts, public acceptance, stakeholder input, etc. (see section 3 ).

8. Identify potentia] SNF consolidation issues and risks [i.e., classification of SNF forms, characterization requirements for storage, inventory and inspection requirements, advantages of different types of dry storage (e.g., individual vaults versus facility), storage of conditioned and unconditioned fuel, and fuel transportation time] and the actions needed for resolution of each issue (see section 5 ).

Completion of these objectives produced the information necessary for development of the INEL Integrated SNF Consolidation Task Team Report (base case) and evaluation of perturbations to the base case scenario.

\subsection{SCOPE}

The scope of the INEL Integrated SNF Consolidation Task Team Report included the identification of resource requirements, schedules, and related activities for INEL SNF management tasks. This included transferring inventories of SNF and SNM to ICPP from storage facilities at PBF, TRA, and TAN; transfers within 
ICPP; normal SNF receipts from NRF and Advanced Test Reactor (ATR); and other related SNF tasks and projects, and on-going project activities.

A number of assumptions were developed to define the scope of the tasks. The assumptions are listed in Appendix $C$. The assumptions provided the baseline to develop schedules and cost estimates that would be realistic relative to the complexity and related uncertainties of the tasks.

It was not within the scope of this Task Team to schedule all of the future ICPP and INEL activities that did not direct7y relate to SNF management. For example, waste management, reactor operations, decontamination and decommissioning (D\&D) of old SNF storage facilities, etc. This task would have required a larger task team and even more time, which is not necessary for examining the feasibility and advantages of different SNF consolidation options. Thus, the resources required for implementing SNF consolidation at the INEL are estimated. However, their availability from within the INEL can only be determined by knowing the entire INEL resource requirements for all activities and their availability during the next 10 years.

\subsubsection{SNF Consolidation Complexities}

INEL SNF consolidation is technically and administratively complex. A systems analysis approach was used to support completeness. Using this approach instills confidence that the proposed plan will work, and that required resources are adequately identified and understood. Factors that complicated this $\mathrm{plan}$ include:

a. The work involves material that is categorized as hazardous, radioactive, and safeguarded. The work must also be accomplished in compliance with (1) applicable federal, state, and tribal laws, rules, and regulations, and (2) applicable DOE Orders, Notices, and manuals. A summary of the pertinent documents is provided in WIN-367, Appendix A.

b. There are a number of continuing or new projects and tasks that may be schedule/funding driven by factors that are totally independent of those associated with SNF consolidation.

c. A management transition will occur when five of the INEL management and operations (M\&O) contracts will be combined by award to a single contractor. The transition and any reduction of work force may reduce the experienced work force and their collective knowledge about existing INEL SNF and their storage facilities.

d. Past reprocessing activities did not include most fuel types for minimizing or eliminating deteriorated SNF. Thus, most of the non-Navy INEL SNF has been in prolonged wet storage, and subsequent7y, some of it has deteriorated.

e. Some of the facilities and equipment, needed for execution of this proposed consolidation, must be reconditioned for use after prolonged periods of inactivity and Tow-priority maintenance support. In some cases, the needed equipment does not exist. For example, new fue 7 handling equipment will be required at ICPP for some of the fuel types to be stored in the Irradiated Fuel Storage Facility (IFSF). In other cases, new personnel must be trained to provided the required SNF support work. 
f. The SNF proposed for consolidation involves several DOE-HQ programs, such as the Office of Nuclear Energy (NE), the Office of Environmental

Management (EM), and the Office of Civilian Radioactive Waste Management (RW). Priorities within these programs varies, making coordination and timely funding of SNF consolidation more challenging.

\title{
1.3.2 Work Breakdown Structure
}

The work breakdown structure (WBS) developed for INEL SNF consolidation is a hierarchial categorization of proposed, ongoing, and related activities. The SNF consolidation WBS closely correlates to the potential INEL SNF consolidation transfers. Arranging the WBS in this manner faci]itates evaluating different alternatives if only part of the overal1 INEL SNF consolidation is implemented.

The INEL Integrated SNF Consolidation WBS shown in Figure 1.3-1 divides the Level 2 elements into four categories:

\author{
AO series - INEL SNF/SNM Consolidation Transfers To ICPP \\ BO series - SNF Consolidation Transfers Within ICPP \\ CO series - SNF/SNM Transfers To And From ICPP \\ DO series - Related SNF Activities At The INEL
}

A typical Level 3 WBS for one of the INEL SNF transfer tasks is shown in Figure 1.3-2. The Leve 3 WBS is designed to separate the transfer task into: (1) preparation activities by the shipper and receiver, and (2) transfer operations by the shipper, carrier, and receiver to ensure the interacting transfer events are connected. The receiver and shipper preparation programs are subdivided and emphasize regulation compliance activities. Regulation compliance is extensive for handling hazardous and/or safeguarded nuclear material.

The $A O$ and $B O$ series WBS elements are described in 12 cost account planning package work statements in Appendix D. A typical set of documentation for 1 of the 12 WBS elements (TRA MTR Canal SNF Characterization, Repackaging, and Transfer to ICPP IFSF) is also included as an example of the level of detailed planning that was implemented for all of the WBS elements. The work documentation includes: a planning package work statement form, a schedule of all task events, and a Basis of Estimate form. The Basis of Estimate shows the estimates for the labor and non-labor resources for each event. Work package documentation sets for the remaining transfers are omitted to minimize the length of this report, but they are available upon request.

\subsection{PRINCIPAL INEL CONSOLIDATION ACTIVITIES}

This consolidation task is more easily understood by dividing it into three parts: (1) SNF/SNM consolidation transfers to and within ICPP (WBS elements AO and $\mathrm{BO}$ ), (2) continued SNF/SNM receipts and transfers at ICPP (WBS element CO), and (3) related SNF activities that are independent of SNF consolidation (WBS element DO).

Part 1 consists of the actual INEL SNF or SNM consolidation transfers to inactivate or retire a SNF or SNM storage facility. They include INEL SNF/SNM consolidation transfers to ICPP (Table 1.4-1) and SNF consolidation transfers within ICPP (Table 1.4-2). Stabilization and future D\&D of empty SNF storage facilities are not included in this plan. 


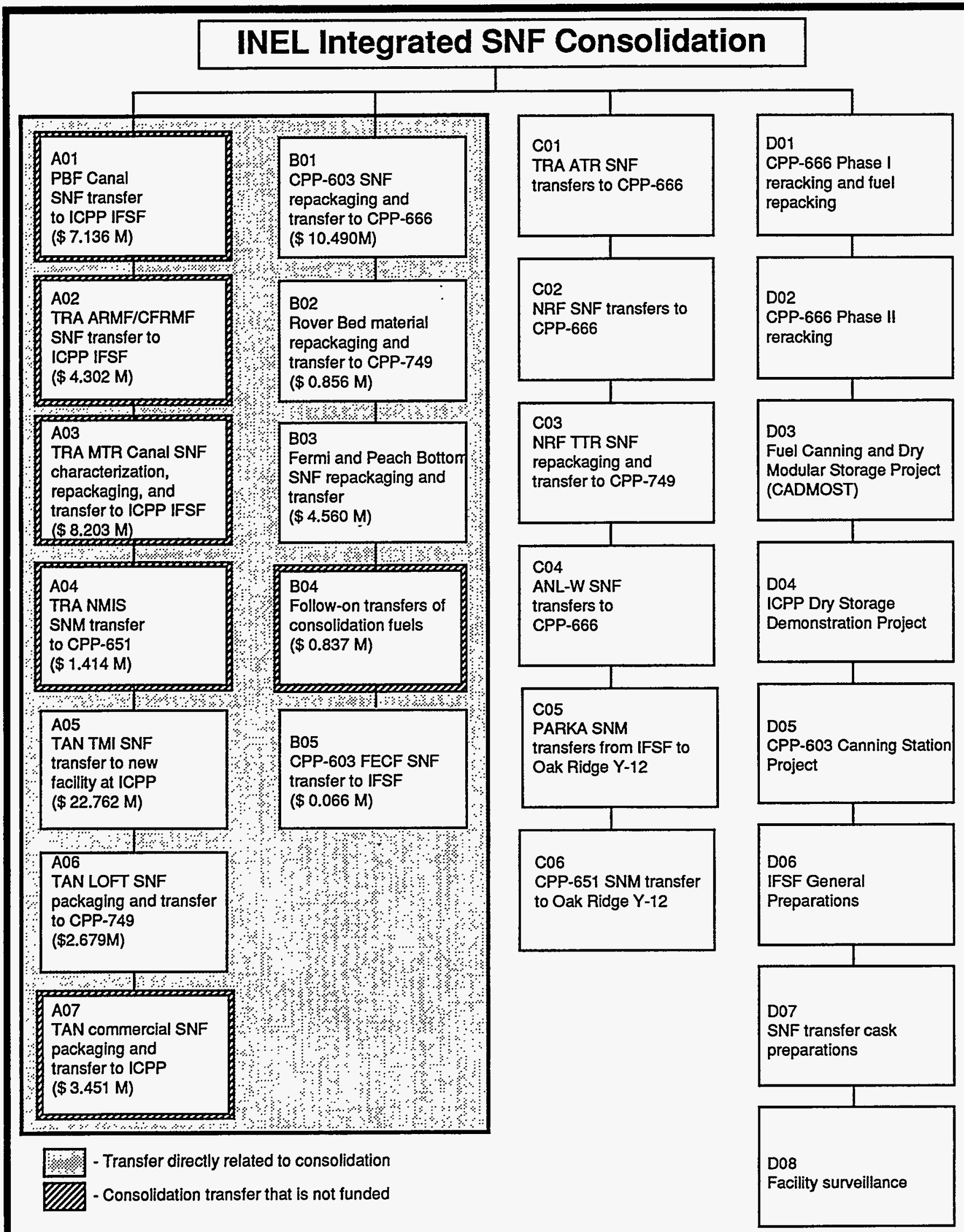

Figure 1.3-1 INEL Integrated SNF Consolidation WBS 


\section{MTR Canal}

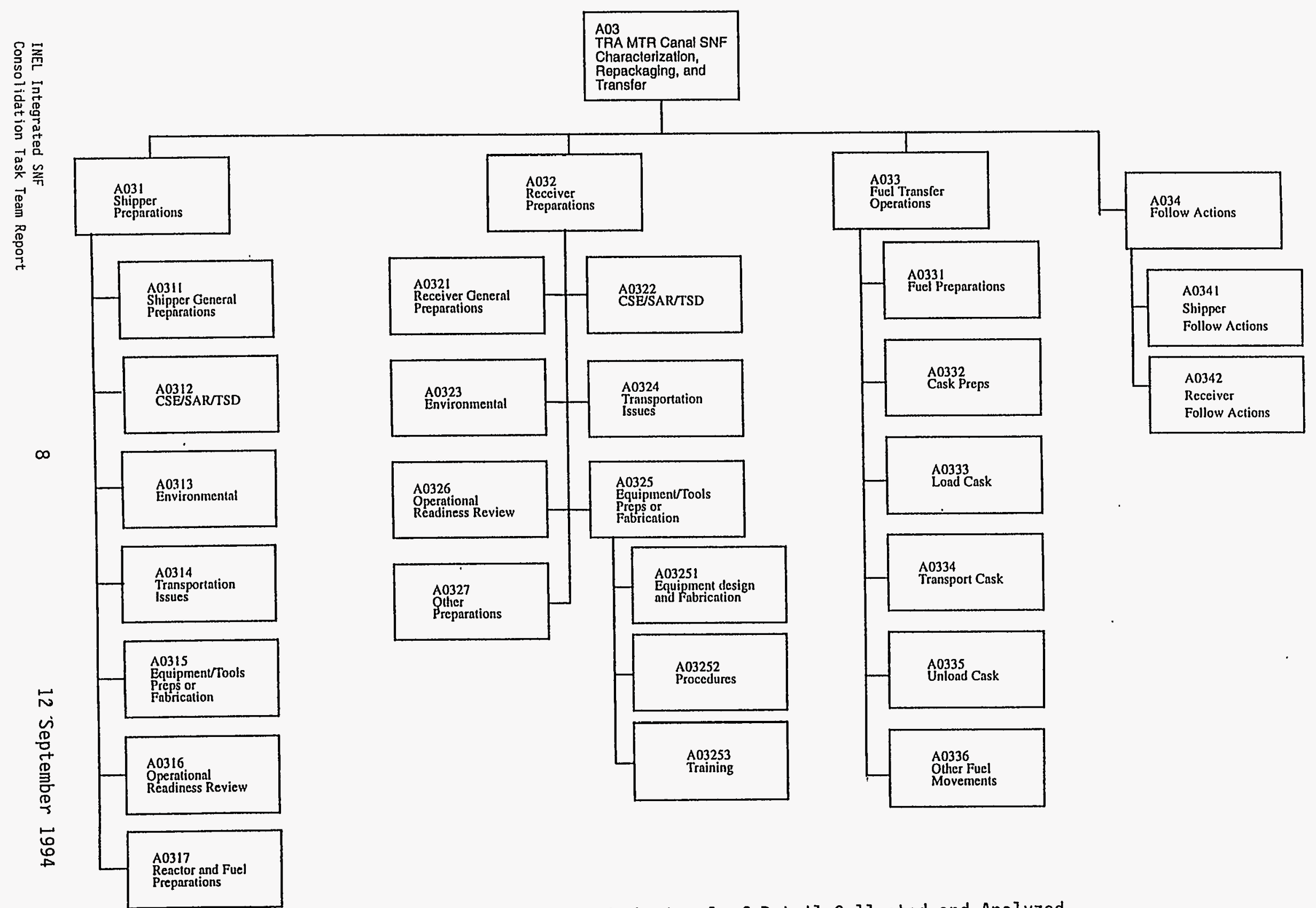

Figure 1.3-2 A WBS Example of the Level of Detail Collected and Analyzed 
Table 1.4-1 INEL SNF/SNM Consolidation Transfers To ICPP

\begin{tabular}{|l|c|c|}
\hline & SNF Consolidation Activity & Sponsor \\
\hline PBF Canal SNF Transfer to ICPP IFSF & A01 & DOE-NE \\
\hline TRA ARMF/CFRMF SNF Transfer to ICPP IFSF & A02 & DOE-NE \\
\hline $\begin{array}{l}\text { TRA MTR Canal SNF Characterization, Repackaging, } \\
\text { and Transfer to ICPP IFSF }\end{array}$ & D03 & DOE-NE \\
\hline TRA NMIS SNM Transfer to CPP-651 & A04 & DOE-NE \\
\hline TAN TMI SNF Transfer to New Facility at ICPP & A05 & DOE-EM \\
\hline TAN LOFT SNF Packaging and Transfer to CPP-749 & A06 & DOE-EM \\
\hline TAN Commercial SNF Packaging and Transfer to ICPP & A07 & DOE-RW/EM \\
\hline \hline
\end{tabular}

Table 1.4-2 SNF Consolidation Transfers Within ICPP

\begin{tabular}{|l|c|c|}
\hline \multicolumn{1}{|c|}{ SNF Consolidation Activity } & WBS Number & Sponsor \\
\hline CPP-603 SNF Repackaging and Transfer to CPP-666 & $\mathrm{BO1}$ & DOE-EM \\
\hline $\begin{array}{l}\text { Rover Bed Material Repackaging and Transfer to } \\
\text { CPP-749 }\end{array}$ & $\mathrm{B} 02$ & DOE-EM \\
\hline Fermi and Peach Bottom SNF Repackaging and Transfer & $\mathrm{B} 03$ & DOE-EM \\
\hline Follow-on Transfers of Consolidation Fuels & $\mathrm{B} 04$ & DOE-EM \\
\hline $\begin{array}{l}\text { CPP-603 Fuel Element Cutting Facility (FECF) SNF } \\
\text { Transfer to IFSF }\end{array}$ & $\mathrm{B} 05$ & DOE-EM \\
\hline
\end{tabular}

Part 2 consists of additional activities reviewed, scheduled, and integrated because of their interaction with the INEL SNF consolidation transfers and draw on common resources. They include continued SNF receipts and shipments at ICPP (Table 1.4-3) and related SNF management activities and projects at the INEL (Table 1.4-4).

Table 1.4-3 SNF/SNM Transfers To And From The ICPP

\begin{tabular}{|l|c|c|}
\hline SNF Interactive Activity & WBS Nümber & Sponsor \\
\hline TRA ATR SNF Transfers to CPP-666 & C01 & DOE-NE \\
\hline NRF SNF Transfers to CPP-666 & C02 & DOE-EM \\
\hline NRF TTR SNF Repackaging and Transfer to CPP-749 & $\mathrm{CO3}$ & DOE-EM \\
\hline ANL-W SNF Transfers to CPP-666 & C04 & $\begin{array}{c}\text { to be } \\
\text { dermined } \\
\text { (TBD) }\end{array}$ \\
\hline PARKA SNM Transfer from IFSF to 0ak Ridge Y-12 & C05 & TBD \\
\hline CPP-651 SNM Transfer to 0ak Ridge Y-12 & C06 & TBD \\
\hline
\end{tabular}


Table 1.4-4 Related SNF Activities At INEL

\begin{tabular}{|l|c|c|}
\hline \multicolumn{1}{|c|}{ SNF Interactive Activity } & HBS Number & Sponsor \\
\hline CPP-666 Phase I Reracking and Fuel Repackaging & D01 & DOE-EM \\
\hline CPP-666 Phase II Reracking & D02 & DOE-EM \\
\hline $\begin{array}{l}\text { Fuel Canning and Dry Modular Storage Project } \\
\text { (CADM0ST) }\end{array}$ & D03 & D0E-EM \\
\hline ICPP Dry Storage Demonstration Project & D04 & DOE-EM \\
\hline CPP-603 Canning Station Project & D05 & DOE-EM \\
\hline IFSF General Preparations & D06 & DOE-EM \\
\hline SNF Transfer Cask Preparations & D07 & TBD \\
\hline Facility Surveillance & D08 & TBD \\
\hline \hline
\end{tabular}

The third part of the consolidation task consists of additional activities that were reviewed to assess their impact on the INEL Integrated SNF Consolidation Plan. Most of these items were not scheduled or integrated, because they do not directiy impact the plan. These activities are listed in Table 1.4-5.

Table 1.4-5 Related Activities That Are Independent of SNF Consolidation

\begin{tabular}{|l|c|}
\hline \multicolumn{1}{|c|}{ SNF Related, Independent Activity } & Sponsor \\
\hline INEL Transportation Safety Manual & DOE-EM \\
\hline Programmatic SNF Management and INEL ER\&WM EIS & DOE-EM \\
\hline Development of D0E SNF Management Program & DOE-EM \\
\hline INEL SNF Vulnerabilities, Phase I Remedial Actions & DOE-EM/NE \\
\hline INEL SNF Vulnerabilities, Phase II Remedial Actions & DOE-EM/NE \\
\hline INEL SNF Vulnerabilities, Phase III Remedial Actions & DOE-EM/NE \\
\hline EG\&G Idaho Facility DOE Order 5480.23 SAR Upgrades & DOE-NE \\
\hline ICPP Faci7ity D0E Order 5480.23 SAR Upgrades & DOE-EM \\
\hline TMI SNF Transfer to TAN-607 & DOE-NE \\
\hline $\begin{array}{l}\text { CPP-601 Process Cell Liquid SNM Solidification, Canning, and } \\
\text { Transfer to CPP-651 }\end{array}$ & DOE-EM \\
\hline $\begin{array}{l}\text { CPP-602 Denitrator Liquid SNM Solidification, Canning, and } \\
\text { Transfer to CPP-651 }\end{array}$ & DOE-EM \\
\hline CPP-749 Upgrade & DOE-EM \\
\hline
\end{tabular}


Table 1.4-5 (continued)

\begin{tabular}{|l|c|}
\hline \multicolumn{1}{|c|}{ SNF Related; Independent Activity } & Sponsor \\
\hline PBF Inactivation & DOE-NE \\
\hline ARMF/CFRMF Inactivation & DOE-NE \\
\hline MTR Canal Inactivation & DOE-NE \\
\hline CPP-603 Fuel Storage Basins D\&D & DOE-EM \\
\hline CPP-603 Fuel Element Cutting Facility D\&D & DOE-EM \\
\hline
\end{tabular}

The activities in parts 1 and 2 are resource-loaded and integrated by the consolidation schedule using Open Plan ${ }^{\text {TM }}$ software. Section 4 discusses the key resource requirements needed to implement the INEL SNF/SNM consolidation plan.

As previously mentioned, this INEL consolidation plan, if implemented, would only be a near-term task that is part of a much larger INEL SNF/SNM program. Figure 1.4-1 depicts the integration of related SNF storage projects at the INEL. Many of them are specific to the preferred storage location, the ICPP. It combines key activities from the $A O, B O, C O$, and $D O$ INEL integrated SNF consolidation WBS elements. This long-term picture may be modified when the Programmatic SNF and INEL ER\&WM EIS ROD defines a new direction.

\subsection{SNF CONSOLIDATION ORGANIZATION ALTERNATIVES}

It is recommended that the control and implementation of the SNF consolidation schedule and plan would occur through one lead operational area, i.e., ICPP. The funding required to implement the SNF transfers and receipts would be distributed by DOE-ID to each of the INEL SNF operational areas as part of their annual budget. This approach has the advantage of using existing planning groups to implement these additional SNF consolidation tasks. However, it requires an expanded management role to ensure the overall integration of the INEL/ICPP activities occur in a timely and integrated manner during this consolidation program.

An alternative option would be to organize the implementation of the plan using a formalized project structure. This approach would place the overall control and implementation of the plan with a project team that would interface with the operational areas. Since this is basically an expansion of on-going SNF management activities, control via operational areas appears to be a more effective strategy provided the additional manpower is allotted (see section 4.3 ). 
FISCAL YE:

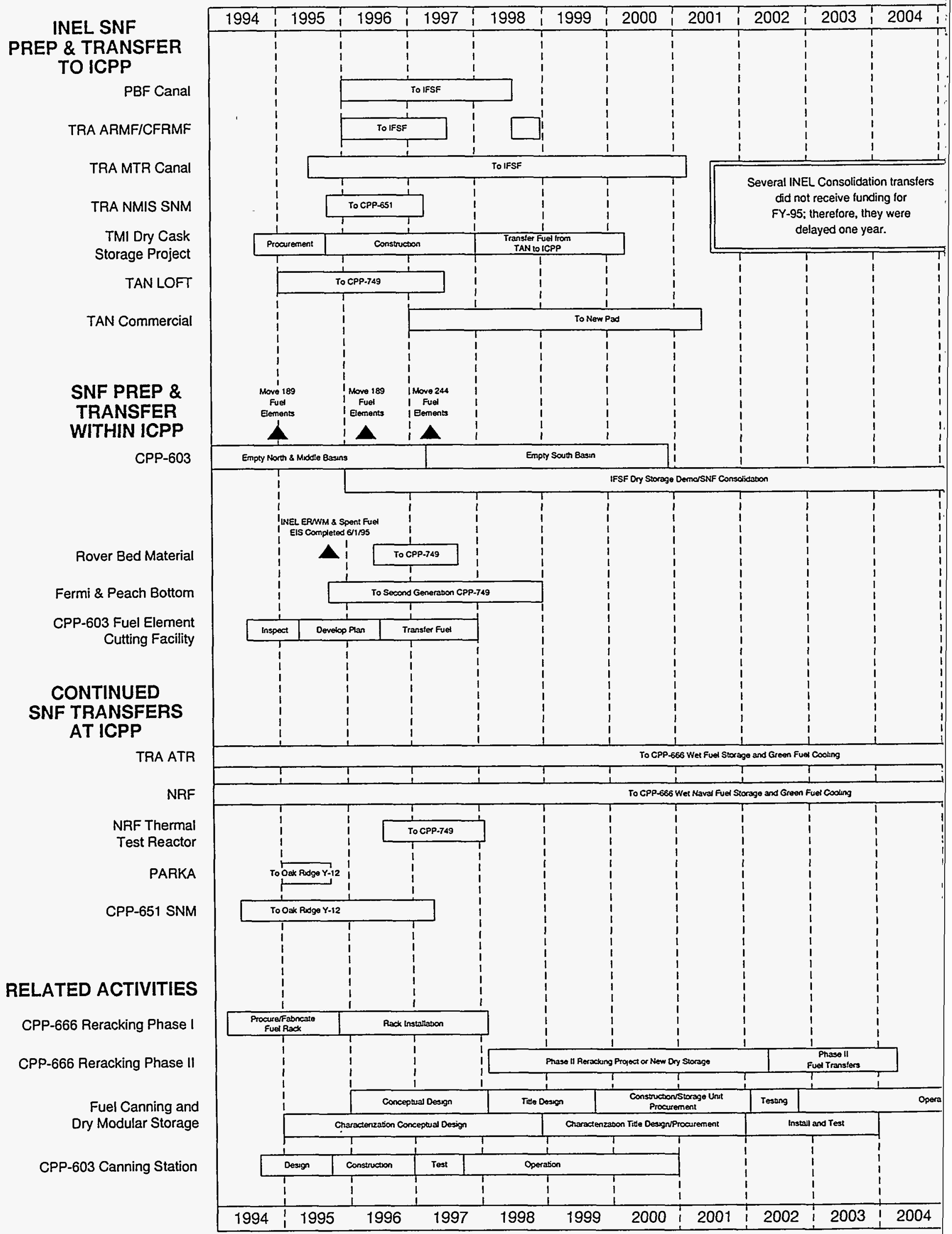




\begin{tabular}{l|l|l|l|l|l|l|l|l}
\hline 005 & 2006 & 2007 & 2008 & 2009 & 2010 & 2011 & 2012 & 2013 \\
\hline
\end{tabular}

$\underline{00}$
]]
LEGEND

Niestone

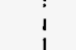

Figure 1.4-1 INEL Long-term Integrated Spent Fuel Program Plan 


\subsection{CONSOLIDATION STRATEGY}

INEL SNF and SNM consolidation strategies were developed to eliminate INEL SNF storage facility ES\&H vulnerabilities, and reduce long-term operating and capital costs prior to final SNF treatment for off-site disposition.

\subsection{PRINCIPAL JUSTIFICATIONS}

The ES\&H vulnerabilities are part of a comprehensive baseline assessment of SNF storage facilities in the DOE complex. Elimination of these vulnerabilities; namely, operation of water-filled storage basins that are not stainless steel lined, not seismically hardened, and have no leak detection, will help reduce ES\&H risks associated with wet SNF storage. DOE-ID also cited the DOE Vulnerability Assessment as a reason for urgency in INEL SNF consolidation.

Reducing long-term operating budgets will help decrease future SNF storage costs. Reducing the long-term operating budget is compatible with DOE-EM plans to D\&D surplus DOE SNF storage facilities. The facility inactivation or transition phase requires removal of stored SNF or SNM. For example, retiring the PBF; Materials Test Reactor (MTR) canal, TAN facilities and CPP-603 wi 11 save about $\$ 6.3 \mathrm{M} /$ year.

Figure 2.1-1 depicts a block-flow diagram of the current, INEL SNF management facility long-range $\mathrm{plan}$. The SNF consolidation is the first phase of the long-range plan. As illustrated in Figure 2.1-1, implementation of this plan wilT reduce the number of INEL SNF storage facilities from 10 to 6 .

Consolidating TRA Nuclear Materials Inspection and Storage (NMIS) SNM, Advanced Reactivity Measurement Facility (ARMF)/ Coupled Fast Reactivity Measurement Facility (CFRMF), and Rover bed material at ICPP will reduce INEL costs due to a decrease in facilities needing safeguards and physical security. The annual cost savings for these activities is estimated to be $\$ 4.9 \mathrm{M} /$ year.

\subsection{CONSOLIDATION GOALS}

The underlying strategy of the Task Team was to achieve INEL SNF consolidation as soon as possible, initiate standardized dry SNF storage to the extent possible, provide maximum operational flexibility, minimize capital and operating risk, and impose no irreversible actions for any of the SNF storage facilities. Flexibility is a key requirement that must be provided to support future national plans and the Programmatic SNF and INEL ER\&WM EIS.

General objectives that support these goals include activities to:

a. Consolidate irradiated and unirradiated fuel storage activities to fewer areas within the INEL, 


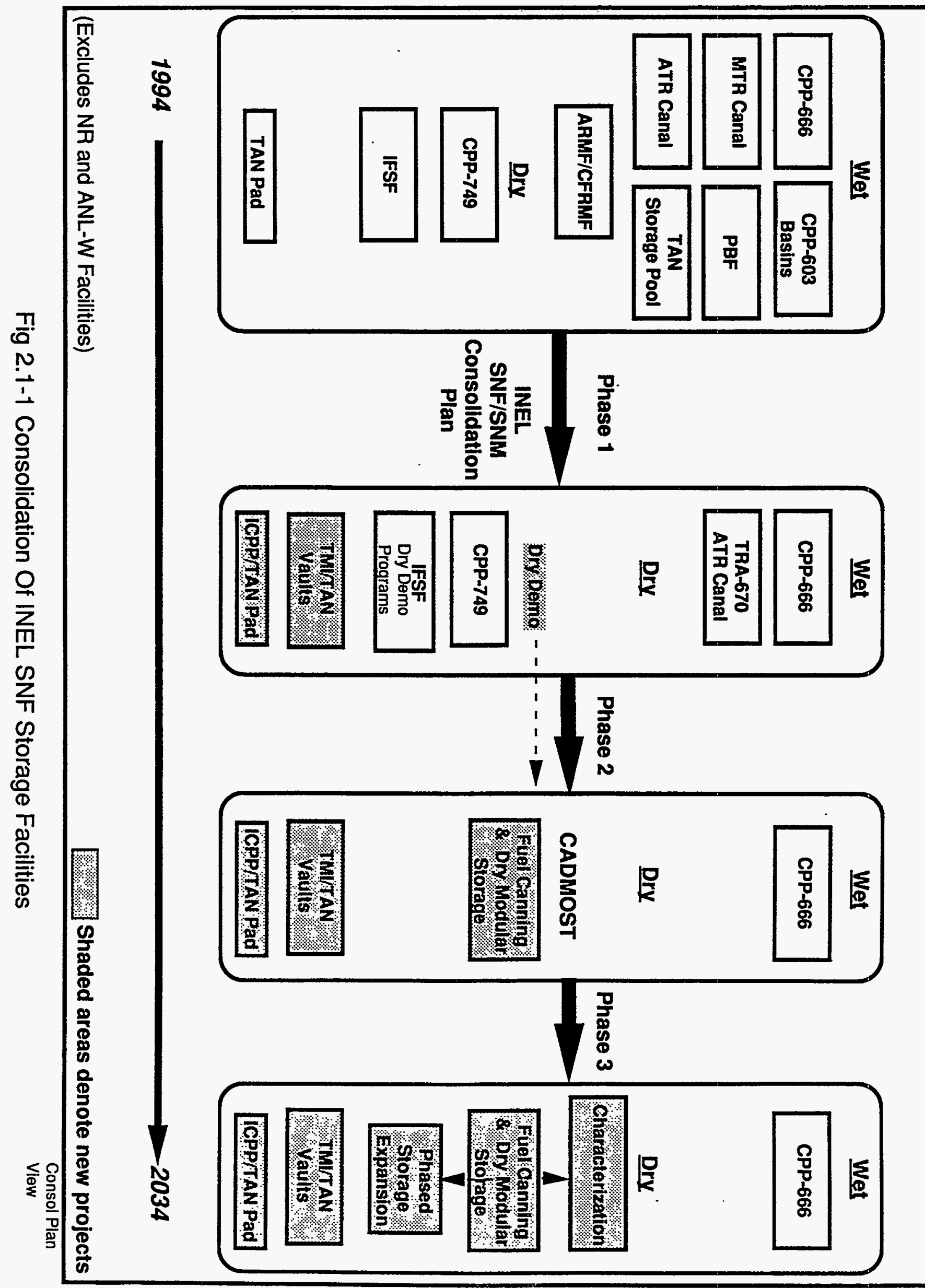


b. Retain a combination of wet and dry storage to take maximum advantage of dry storage costs and provide cooling for recently irradiated nuclear fuel,

c. Transfer all fuel types that do not require wet storage to dry storage,

d. Identify ways that will minimize the SNF storage risk and space requirements,

e. Establish a phased and expandable SNF characterization capacity that provides timely support for near-term INEL SNF consolidation tasks and future SNF dispositioning programs,

f. Retain the retired SNF storage areas in a safe and stabilized condition until their potential future uses are understood and finalized. Costs to retain these facilities in a safe and stabilized condition are not included in the scope of this study,

g. Develop modeling capability for INEL fuel transfers that ensure systems analyses for future transfers and determination of the best location for storing the additional fuel,

h. Use existing transfer equipment, procedures, safety documentation, experienced personnel, etc., to minimize unnecessary cost and confusion,

i. Minimize SNF receipts at IFSF during periods of high activity, e.g., SNF transfers for CPP-749 upgrades, and possible SNF transfer/canning from CPP-603 south basin,

j. Avoid scheduling any new INEL SNF consolidation transfers to CPP-666 for the next 10 years [current CPP-603 transfers and continued SNF receipts (ATR, Navy) fully schedule the facility],

k. Use available storage space in IFSF to expedite INEL SNF consolidation, i.e., avoid cost and time delays of new construction,

1. Use IFSF robotics support features to implement dry SNF storage demonstration programs,

m. Provide adequate safeguards and security for all fuel inventories,

n. Use related projects, SAR updates, etc. to share costs and minimize data development time for related SNF consolidation tasks,

o. Identify potential programmatic changes for individual facilities and SNF transfers that could produce significant improvements and reduce cost for the overal1 INEL SNF consolidation plan,

p. Utilize INEL resources for developing critical path deliverables; e.g., use INEL criticality safety experts for new or updated criticality safety calculations and SARs, 
q. Develop the overall integrated consolidation schedule so that all or any part of it can be implemented in accordance with available funding,

r. Design new SNF support equipment using input from facility operators, and

s. Validate schedule assumptions and proposed activity integration via field/operations review.

\subsection{BASE CASE OVERVIEW}

The base case, consolidate INEL SNF as soon as possible, was developed to identify (1) how fast the various INEL ES\&H vulnerability issues could be resolved, (2) the total resources needed, and (3) the critical path resource issues. The base case evolved from the assumptions Tisted in Appendix $C$ and the following initial observations.

- CPP-666 is fully scheduled with CPP-603 transfers and continued receipts of Navy and ATR SNF. Therefore, SNF/SNM transfer scenarios from INEL SNF consolidation that require interacting with CPP-666 are to be avoided.

- Continued wet storage for the consolidated SNF wi17 probab7y require additional packaging and is not preferred for long-term storage. Thus, transfer strategies involving dry storage options for the consolidated SNF are sought.

- The resource requirements (time, manpower, and money) to build new storage facilities should be avoided, if existing, safe storage facilities are available, namely, use IFSF or CPP-749 for consolidation.

- Because of the federal court order, CPP-603 transfers have priority over other SNF consolidation. Schedule dry canning of CPP-603 south basin SNF at the IFSF to envelop worst case transfer conditions, i.e., plans for maximum number of SNF interface issues and constraints of IFSF.

- Provide resources to support a dry storage demonstration program for alt SNF that has not been stored dry, and select storage facilities that can provide remote inspection capability.

- Locate and design the new ICPP Three Mile Island (TMI) SNF dry storage facility to be expandable.

Given these baseline observations, the preliminary planning process proceeded to identify how the SNF would be transferred (casks, cranes, and other facility interfaces) and stored.

The three principal ICPP SNF receipt areas (see Figure 2.3-1) include CPP-666 (wet storage), IFSF, and CPP-749 (dry storage). Some new construction for dry storage of TMI and TAN commercial SNF would be needed. SNM would be consolidated and stored in CPP-651. These storage areas can operate almost independent of each other, provided their common resource requirements (e.g., trained personnel, shared equipment) are adequate. 


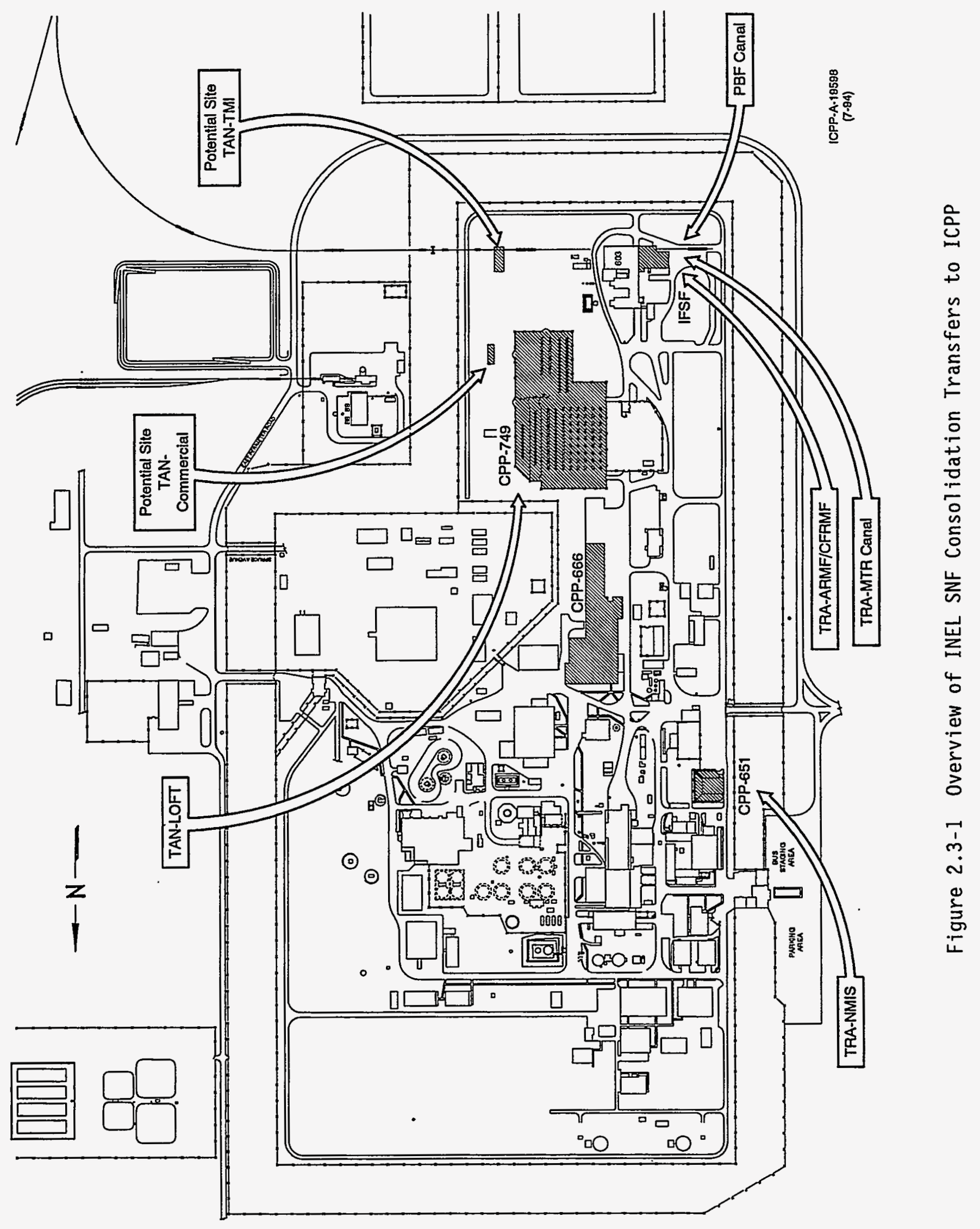


The consolidation strategy for the "as soon as possible" base case attempted to minimize any interface requirements between these storage areas. This approach expedites the consolidation process by scheduling parallel rather than series transfers to these storage areas.

Figure 2.3-2 provides a summary overview of the initial planning strategy for each of the SNF transfers. PBF, TRA MTR canal, and TRA ARMF/CFRMF SNF is stored wet, but will be transitioned to dry storage at the IFSF (no physical interface with CPP-666 is required). The TAN SNF wi17 be placed in dry storage. TAN TMI will be placed in a newly constructed facility, TAN LOFT will be placed in CPP-749, and TAN commercial will be relocated to a new pad (no physical interface with IFSF or CPP-666).

\subsection{TECHNICAL TASK EXAMPLE (TRA MTR CANAL SNF CHARACTERIZATION, REPACKAGING, AND TRANSFER TO IFSF)}

A description of the MTR canal transfer is provided as an example of the information that was developed and analyzed for each of the consolidation transfers. This section discusses the process used to move the MTR canal SNF to the ICPP. Summary information on the MTR canal transfer is given in Table 2.4-1.

Summary tables 2.4-2 through 2.4-12 were prepared for each of the INEL SNF or SNM consolidation transfers to and within the ICPP (AO and BO WBS series). Additional detailed information on each of the INEL transfers to ICPP (AO series) can be found in Appendix E.

\subsubsection{Overview of SNF Transfers from the MTR Canal}

The MTR canal was built in the early 1950s to support defueling and handling of experiments. Figure 2.4-1 shows the canal. The last program to use the canal was the Thermal Fuels Behavior Program (TFBP). SNF, predominant7y from PBF experiments, is stored in the canal. The SNF is in rods, sections of rods, scrap, and metallographic mounts. Some rods are stored in sealed stainless steel tubes. However, most SNF has been accumulated into cylindrical aluminum canisters. Additional characterization and repackaging will be performed in the TRA Hot Cells before transfer to ICPP. Equipment will be needed in the Hot Cell to consolidate the SNF into new storage canisters.

Transporting the SNF to ICPP will require two moves. The first move will transfer SNF to a TRA Hot Cell. The existing Hot Cells Carrier, also known as the White Elephant Number 2 (WE-2), will be placed on the main floor of the MTR reactor building. The cask will be removed from the transport dolly with the existing MTR bridge crane. The bolts and 1 id will be removed and the cask lowered into the pool. A number of canisters will be transferred to the cask and the lid replaced. The WE-2 will then be lifted out of the canal and allowed to drain. The lid bolts will be installed, the cask decontaminated, and returned to the dolly.

Work at the TRA Hot Cell begins with unloading the WE-2. The cask is horizontal and is designed to interface with cell entry ports. An end plug 


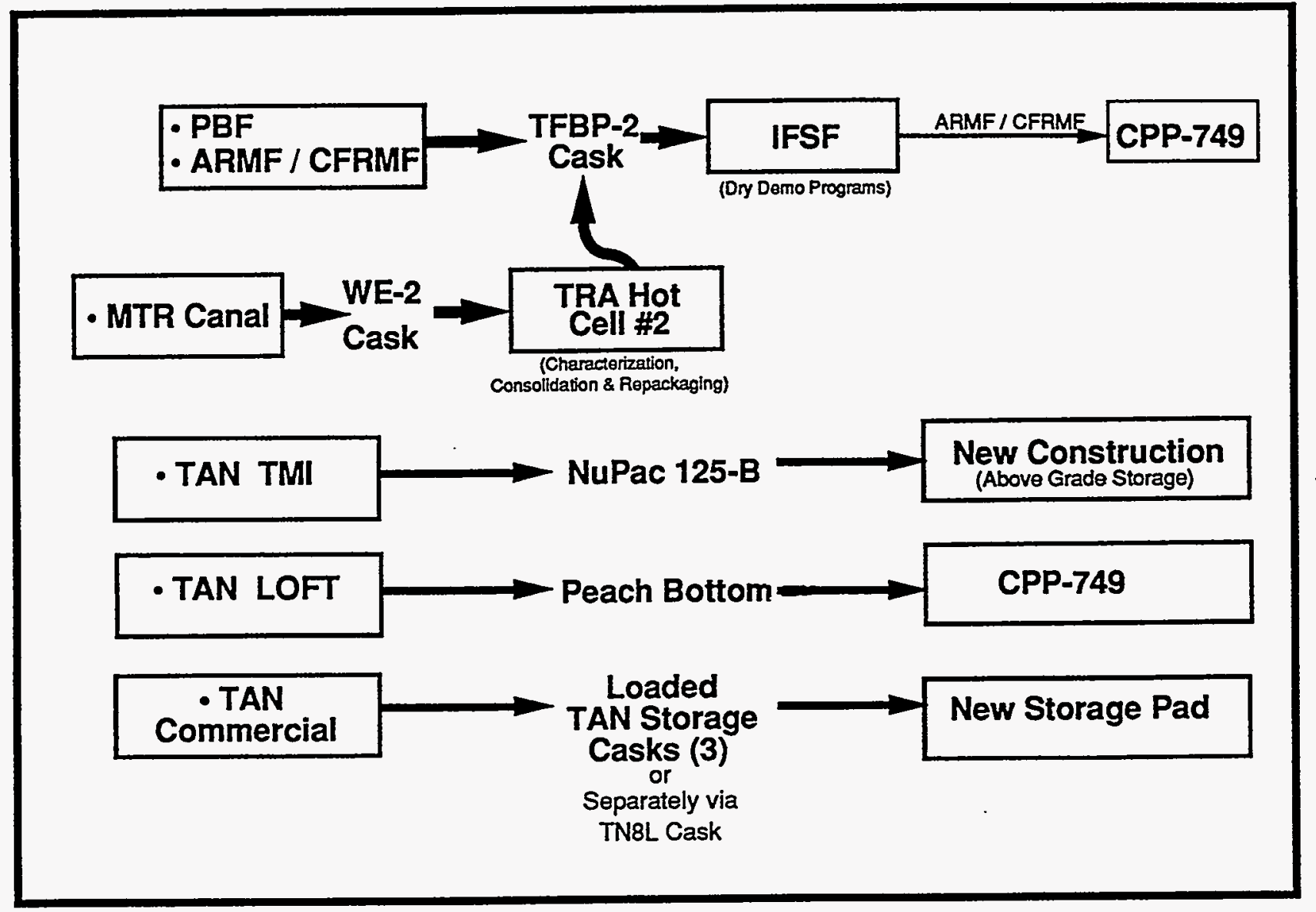

Figure 2.3-2 Overview of Fuel Transfer Scenarios 


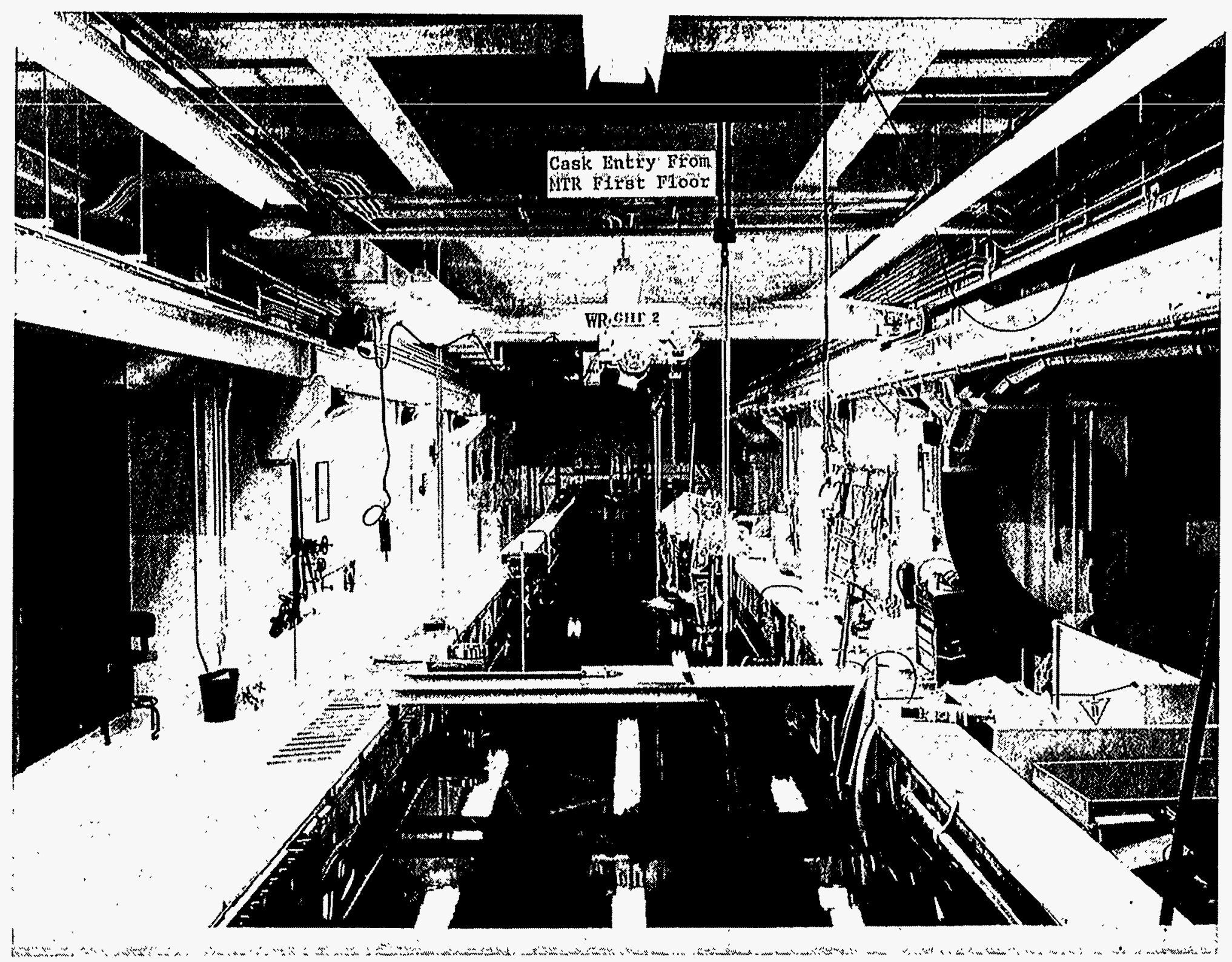

Figure 2.4-1 MTR canal was used as part of the test train assembly facility for underwater handling of irradiated components. 
will be opened on WE-2 and the MTR canal canister will be pushed into the cell using a rod: The MTR pool canisters will be opened, dried, contents inspected, physical condition characterized, consolidated, and placed into a canister designed for ICPP interim storage. It is expected that several MTR canal canisters can be consolidated to one ICPP storage canister. After an ICPP storage canister is filled, the canister will be closed and loaded into the TFBP-2 cask.

The TFBP-2 cask will be used to transfer SNF to ICPP. The cask will be transported to ICPP during daylight hours at 5 to $15 \mathrm{mph}$. The transfer will be timed so it does not occur during peak traffic. Escort vehicles will be located in front and behind the truck. A similar procedure has proven to be safe in the past.

At the ICPP, the cask transporter will be surveyed for radiation and then accepted by the facility. The cask will then be moved to the IFSF where the cask will be removed from the transporter. Prior to placing the cask on the IFSF transfer cart, an adapter plate configured for the TFBP-2 cask will be placed in the cart. The cask will be loaded in the adapted IFSF transfer cart. The lid bolts will be loosened, the majority of them removed, and the rigging attached to the 1 id.

The cask will then be moved into the IFSF shielded area where the lid will be remotely removed. Loaded MTR canal SNF canisters will be remotely removed from the cask, placed into storage inserts, and then placed into IFSF storage canisters final storage in the IFSF. The cask 1 id wil1 then be rep 7 aced and the cask removed from the IFSF. Lid bolts will be replaced, and the cask returned to the transporter. The cask will be surveyed for radioactive contamination and prepared for empty return to the TRA Hot Cells facility for reloading. A typical transfer cycle is expected to take about 11 days.

\subsubsection{Development of Detailed Schedule and Cost Information}

The additional planning detail provided in Appendix D clearly demonstrates the level of detail that has gone into this planning effort to ensure its completeness and accuracy. Numerous INEL personnel were consulted to help develop this data (see Appendix B). Their knowledge, combined with that of the Task Team, provided for the first time an in-depth, scoping analysis of the INEL SNF consolidation management issues.

Wherever possible, resource requirements were benchmarked against recent plant experience. The potential impacts of ever changing regulations and political policies were also monitored and incorporated to enhance the accuracy of the resource requirements. These estimates were reviewed by an ICPP validation committee in May and June. The validation committee provided additional independent review and detail. 
Table 2.4-1 WBS AO3 - TRA MTR Canal SNF Characterization, Repackaging, and Transfer to ICPP IFSF

\begin{tabular}{|c|c|}
\hline Background: & $\begin{array}{l}\text { The MTR canal was constructed in } 1952 \text { as part of the MTR Program. The canal } \\
\text { functioned as the storage and handling facility for irradiated fuel elements and } \\
\text { experiments from the MTR. The MTR was shut down in } 1970 \text {, and all MTR fuel } \\
\text { and experiments were removed from the canal following reactor shutdown. Since } \\
\text { about } 1973 \text {, the canal has been used to store, refurbish, handle, and dismantle PBF } \\
\text { reactor elements from the TFBP. The MTR canal is non-operational except for } \\
\text { storage of the PBF SNF. }\end{array}$ \\
\hline DOE Sponsor: & DOE-NE \\
\hline Drivers: & $\begin{array}{l}\text { Economic - DOE wants to reduce costs associated with maintaining the facility. } \\
\text { One method is to remove the SNF from the facility and inactivate the MTR canal. } \\
\text { ES\&H Vulnerabilities - DOE wants to eliminate SNF storage vulnerabilities, which } \\
\text { for MTR are: lack of leak detection and leak trending, inadequate corrosion } \\
\text { monitoring, an unlined pool nearing its end of life, and canal and storage equipment } \\
\text { that are not seismically qualified. }\end{array}$ \\
\hline Preferred Action: & $\begin{array}{l}\text { Transfer SNF (WE-2 cask) stored in the MTR canal to Hot Cell, repackage SNF (3-1 } \\
\text { reduction), ship to ICPP (TFBP-2 cask), place in interim storage at the IFSF, and } \\
\text { conduct a dry storage demonstration program. }\end{array}$ \\
\hline Alternative Actions: & $\begin{array}{l}\text { 1) Leave SNF in place and maintain facility in current status. } \\
\text { 2) Package the SNF and upgrade the facility. }\end{array}$ \\
\hline Transfer Cask: & $\begin{array}{l}\text { WE-2 to TRA Hot Cell } \\
\text { TFBP-2 to ICPP IFSF }\end{array}$ \\
\hline Transfers: & About 90 from the MTR canal to TRA hot cell, and about 33 to ICPP \\
\hline Time Frame: & Transfers: June 98 through Nov 99 \\
\hline Prerequisites: & $\begin{array}{l}\text { 1) Update IFSF Plant Safety Document Approved Fuels List. } \\
\text { 2) Design and fabricate IFSF canister inserts and canisters. } \\
\text { 3) Write and approve MTR fuel handling characterization and transport procedures.* } \\
\text { 4) Write MTR fuel inspection plan. } \\
\text { 5) Train operators for MTR fuel characterization, transfer*, and receipt. * } \\
\text { 6) Prepare and approve TFBP-2 Transport Plan. } \\
\text { 7) Upgrade TRA Hot Cells Facility. } \\
\text { 8) Design and fabricate MTR canal and Hot Cell operational equipment. } \\
\text { 9) Prepare Hot Cell Safety Analysis Upgrades. } \\
\text { 10) Perform Shipper Operational Readiness Review and Receiver Readiness } \\
\text { Assessment.* } \\
\text { *Both a shipper and a receiver activity. }\end{array}$ \\
\hline NEPA: & $\begin{array}{l}\text { The present assessment is that this transfer is encompassed under current } \\
\text { activities. }\end{array}$ \\
\hline Critical Issues: & FY-96 funding must be moved up to FY-95 to proceed with proposed work. \\
\hline Est. Total Cost: & $\$ 8.203 \mathrm{M}$ \\
\hline Funded: & No \\
\hline Est. Pay Back Period: & $\begin{array}{l}31.0 \text { years (Assumes the only savings are from reduced operating costs. The cost } \\
\text { of possible accident recovery is not included). }\end{array}$ \\
\hline Related Documents: & $\begin{array}{l}\text { U.S. DOE, 1993, Spent Fuel Working Group Report on Inventory and Storage of the } \\
\text { Department's Spent Nuclear Fuel and Other Reactor Irradiated Nuclear Materials and Their } \\
\text { Environmental, Safety, and Health Vulnerabilities, December } 1993 . \\
\text { Buckland, R. J. et al, 1993, INEL D\&D Long-Range Plan, October } 1993 . \\
\text { LaBuy, S. A., and Shaber, E. L., MTR Fuel Removal Program Plan, Report Number PG-T-94- } \\
\text { O03, Revision O, April 27, } 1994 \text {. } \\
\text { LaBuy, S. A., MTR Canal Fuel Characterization Report, EDF-TRA-ATR-958, May 12, } 1994 .\end{array}$ \\
\hline
\end{tabular}




\begin{tabular}{|c|c|}
\hline Background: & $\begin{array}{l}\text { The PBF canal was built in the late } 1960 \text { s as part of the reactor facility. The PBF reactor } \\
\text { and control areas formerly supported the TFBP and the Severe Fuel Damage Program } \\
\text { testing. The PBF driver core is composed of stainless steel-clad, uranium dioxide and } \\
\text { zirconia fuel pins. The driver core is stored in two fuel storage racks in the PBF canal. } \\
\text { The fuel pins are stored in various size containers. } \\
\text { The Boron Neutron Capture Therapy Program was proposed for the PBF. However, it has } \\
\text { not been supported to date, and DOE shutdown PBF in } 1992 \text {. A consorium of medical } \\
\text { doctors recently expressed interest in leasing PBF for Boron Neutron Capture Therapy. } \\
\text { This therapy is used to treat brain cancer. A decision concerning a possible lease } \\
\text { agreement is expected in July } 1994 \text {. If an agreement is reached, the SNF at PBF could } \\
\text { remain in place. }\end{array}$ \\
\hline DOE Sponsor: & DOE-NE \\
\hline Drivers: & $\begin{array}{l}\text { Economic - DOE wants to reduce costs associated with maintaining the facility. One method } \\
\text { is to remove the SNF from the facility and inactivate PBF. } \\
\text { ES\&H Vulnerabilities - DOE wants to eliminate SNF storage vulnerabilities, which for PBF is } \\
\text { inadequate corrosion monitoring. }\end{array}$ \\
\hline Preferred Action: & $\begin{array}{l}\text { Package SNF stored in the PBF canal, ship to ICPP, and place in interim storage at the } \\
\text { IFSF. }\end{array}$ \\
\hline Alternative Actions: & $\begin{array}{l}\text { 1) Store SNF at CPP-666 (wet). } \\
\text { 2) Store SNF at MTR canal (wet). } \\
\text { 3) Leave SNF in place and maintain facility in current status. }\end{array}$ \\
\hline Transfer Cask: & TFBP-2 \\
\hline Transfers: & 40 \\
\hline Time Frame: & Preps: Oct 94 through March 96 \\
\hline Prerequisites: & $\begin{array}{l}\text { 1) Restaff and retrain PBF. } \\
\text { 2) Restore PBF equipment to condition prior to shutdown. } \\
\text { 3) Update IFSF Plant Safety Document Approved Fuels List. } \\
\text { 4) Design and fabricate IFSF canister inserts baskets. } \\
\text { 5) Design and fabricate an adapter plate for the IFSF transfer cart. } \\
\text { 6) Write and approve PBF fuel handling procedures. } \\
\text { 7) Write PBF fuel inspection plan for dry storage. } \\
\text { 8) Train operators for PBF fuel receipt. } \\
\text { 9) Fabricate fuel handling tools. } \\
\text { 10) Perform Shipper Operational Readiness Review and Receiver Readiness Assessment. } \\
\text { * Both a shipper and a receiver activity. }\end{array}$ \\
\hline NEPA: & The present assessment is that this transfer is encompassed under current activities. \\
\hline Critical Issues: & $\begin{array}{l}\text { 1) FY-96 funding must be moved up to FY-95 to proceed with the proposed schedule. } \\
\text { 2) TFBP-2 cask eligibility for PBF transfers must be verified. } \\
\text { 3) IFSF transfer cart must be adapted to interface with the TFBP-2 cask. }\end{array}$ \\
\hline Est. Total Cost: & $\$ 7.136 \mathrm{M}$ \\
\hline Funded: & No \\
\hline Est. Pay Back Period: & 3.3 years \\
\hline Related Documents: & $\begin{array}{l}\text { U.S. DOE, } 1993, \text { Spent Fuel Working Group Report on Inventory and Storage of the } \\
\text { Department's Spent Nuclear Fuel and Other Reactor Irradiated Nuclear Materials and Their } \\
\text { Environmental, Safety and Health Vulnerabilities, December 1993. } \\
\text { Grumbly, T. P. letter to Acting Director of Nuclear Energy, NE-1, Transition of the Power Burst } \\
\text { Facility, dated December 6, } 1993 \text {. } \\
\text { Hamer Jr., D. L. letter to W. C. Moffitt, OPE-SNF-WJM-93067, Program Execution Guidance } \\
\text { for Site Fuel Consolidation, dated December 29, } 1993 \text {. } \\
\text { Brolin, E. E. letter to A. A. Pitrolo, Power Burst Facility (PBF) Management Options, dated } \\
\text { January } 11.1994 . \\
\text { Pitrolo, A. A. letter to J. Okeson, RTD-1 10-92, dated April 8, } 1992 \text {. } \\
\text { Leatham, J., Proiect Management Plan for Fuel Relocation and Stand-Down of the Power Burst } \\
\text { Facility, PG-T-94-005, May 23, } 1994 \text {. }\end{array}$ \\
\hline
\end{tabular}




\begin{tabular}{|c|c|}
\hline Background: & $\begin{array}{l}\text { The ARMF/CFRMF building and canal were designed and constructed from } 1958 \\
\text { through } 1960 \text {. The two facility reactors, ARMF-1 and CFRMF (known as ARMF-2 } \\
\text { until it was modified in 1968) were designed and fabricated in the same time } \\
\text { frame. } \\
\text { The fuel is located in the two reactors. Both reactors use the same type of fuel, } \\
\text { fully enriched U-235 Materials Test Reactor-type elements. Operation of the } \\
\text { ARMF/CFRMF was suspended in February } 1991 \text {. No programmatic use is planned } \\
\text { for these reactors. The facility is scheduled for inactivation in FY-95, which } \\
\text { requires removal of the enriched aluminum-clad fuel. }\end{array}$ \\
\hline DOE Sponsor: & DOE-NE \\
\hline Drivers: & $\begin{array}{l}\text { Economic - DOE wants to reduce costs associated with maintaining the facility. } \\
\text { One method is to remove the SNF from the facility and inactivate the } \\
\text { ARMF/CFRMF building and canal. } \\
\text { ES\&H Vulnerabilities - DOE wants to eliminate SNF storage vulnerabilities, which } \\
\text { for TRA ARMF/CFRMF is SNF stored in an inactive reactor. }\end{array}$ \\
\hline Preferred Action: & $\begin{array}{l}\text { Ship SNF stored in the ARMF/CFRMF canal to ICPP, place it in interim storage at } \\
\text { the IFSF, and conduct a dry storage demonstration program. ARMF fuel will be } \\
\text { transferred to CPP- } 749 \text { at a later date. }\end{array}$ \\
\hline Alternative Actions: & $\begin{array}{l}\text { 1) Leave SNF in place and maintain facility in current status. } \\
\text { 2) Transfer SNF in fuel element form directly to CPP-749, and bypass ICPP IFSF } \\
\text { and an opportunity to conduct a dry storage demonstration program. See } \\
\text { Table 2.4-11 for description of the follow on activity. }\end{array}$ \\
\hline Transfer Cask: & TFBP-2 \\
\hline Transfers: & 17 \\
\hline Time Frame: & Transfers: May 97 through Sept 97 \\
\hline Prerequisites: & $\begin{array}{l}\text { 1) Update IFSF Plant Safety Document Approved Fuels List. } \\
\text { 2) Design and fabricate IFSF canister inserts. } \\
\text { 3) Write and approve ARMF/CFRMF fuel handling procedures. * } \\
\text { 4) Write ARMF/CFRMF fuel inspection plan. } \\
\text { 5) Design and fabricate an adapter plate for the IFSF transfer cart. } \\
\text { 6) Train operators for ARMF/CFRMF fuel transfer and receipt.* } \\
\text { 7) Perform Shipper and Receiver Readiness Assessments.* } \\
\text { *Both a shipper and a receiver activity. }\end{array}$ \\
\hline NEPA: & $\begin{array}{l}\text { The present assessment is that this transfer is encompassed under current } \\
\text { activities. }\end{array}$ \\
\hline Critical Issues: & $\begin{array}{l}\text { 1) TFBP-2 cask eligibility for ARMF/CFRMF transfers must be verified. } \\
\text { 2) IFSF transfer cart must be modified to interface with the TFBP- } 2 \text { cask. }\end{array}$ \\
\hline Est. Total Cost: & $\$ 4.302 \mathrm{M}$ \\
\hline Funded: & No \\
\hline Est. Pay Back Period: & 15.6 years \\
\hline Related Documents: & $\begin{array}{l}\text { U.S. DOE, } 1993 \text {, Spent Fuel Working Group Report on Inventory and Storage of the } \\
\text { Department's Spent Nuclear Fuel and Other Reactor Irradiated Nuclear Materials and Their } \\
\text { Environmental, Safety, and Health Vulnerabilities, December } 1993 \text {. } \\
\text { Hamer Jr., D. L. letter to W. C. Moffitt, OPE-SNF-WJM-93067, Program Execution } \\
\text { Guidance for Site Fuel Consolidation, dated December } 29,1993 \text {. } \\
\text { LaBuy, S. A., ARMF/CFRMF Fuel Removal Program Plan, PG-T-94-004, May 12, } 1994 . \\
\text { LaBuy, S. A. ARMF/CFRMF Fuel Characterization Report, EDF-TRA-ATR-959, } \\
\text { May 12, } 1994 \text {. }\end{array}$ \\
\hline
\end{tabular}




\begin{tabular}{|c|c|}
\hline Background: & $\begin{array}{l}\text { Category I and II SNM inventories are maintained at three INEL areas: TRA, } \\
\text { ICPP, and ANL-W. Because of the SNM quantities in inventory at these } \\
\text { locations, complete consolidation (using existing facilities) is not possible. } \\
\text { However, consolidation of TRA SNM and ICPP SNM can be accomplished in } \\
\text { CPP-651. }\end{array}$ \\
\hline DOE Sponsor: & DOE-NE \\
\hline Drivers: & $\begin{array}{l}\text { Economic - DOE wants to reduce costs associated with maintaining these } \\
\text { facilities. One method is to remove the SNM from TRA and inactivate TRA-621. } \\
\text { The saving is due to a reduction of safeguards and physical security needs. }\end{array}$ \\
\hline Preferred Action: & Ship to ICPP and place in interim storage at CPP-651. \\
\hline Alternative Actions: & Leave SNM in place at TRA and maintain current status. \\
\hline Transfer Cask: & Existing ATR and Engineering Test Reactor (ETR) shipping containers (boxes). \\
\hline Transfers: & 24 \\
\hline Time Frame: & Transfers: Mar 96 through Jul 96 \\
\hline Prerequisites: & $\begin{array}{l}\text { 1) Discontinue hydraulic testing of ATR fuel elements at INEL prior to consolidation. } \\
\text { 2) Refurbish and use ETR shipping containers for transferring the ETR and General } \\
\text { Electric Test Reactor (GETR) fuels to the ICPP } \\
\text { 3) Complete readiness assessment to receive SNM. } \\
\text { 4) Update safety documentation to allow receipt and storage of SNM. } \\
\text { 5) Upgrade alarm system at CPP-651. }\end{array}$ \\
\hline NEPA: & $\begin{array}{l}\text { The present assessment is that this transfer is encompassed under current } \\
\text { activities. }\end{array}$ \\
\hline Critical Issues: & $\begin{array}{l}\text { New racks will be designed, procured, and installed in north vault room for } \\
\text { storage of ATR, ETR, and GETR fuel. }\end{array}$ \\
\hline Est. Total Cost: & $\$ 1.414 \mathrm{M}$ \\
\hline Funded: & No \\
\hline Est. Pay Back Period: & 1.8 years \\
\hline Related Documents: & $\begin{array}{l}\text { Hevlow, J. E. et al, } 1994 \text {, Task Team Report - Consolidation of TRA and ICPP } \\
\text { Special Nuclear Máterials in CPP-651, February } 28,1994 \text {. } \\
\text { Burns Jr., T. F. letter to E. N. Fray and W. C. Moffitt, AM/OPA-SSD-SMM-94-052, } \\
\text { Task Team Report-Consolidation of TRA and ICPP Special Nuclear Materials in CPP- } \\
651 \text {, dated April 7, 1994. } \\
\text { Burns Jr., T. F. letter to W. C. Moffitt and E. N. Fray, AM/OPA-SSD-SMM-94-076, } \\
\text { Consolidation of TRA and ICPP Special Nuclear Materials in CPP-651, dated } \\
\text { June 20, } 1994 \text {. } \\
\text { Dials, G. E. letter to E. N. Fray and W. C. Moffitt, AM/OPA-SSD-SMM-93-033, Joint } \\
\text { EG\&G-WINCO Cost/Benefit Study - Consolidation of Special Nuclear Materials, dated } \\
\text { November } 8,1993 \text {. }\end{array}$ \\
\hline
\end{tabular}


Table 2.4-5

WBS AO5 - TAN TMI SNF Transfer to New Facility at ICPP

\begin{tabular}{|c|c|}
\hline Background: & $\begin{array}{l}\text { TMI core debris shipments to the INEL began in FY-86. The shipments were } \\
\text { part of a contractual agreement between DOE and General Public Utilities } \\
\text { Nuclear. DOE agreed to accept the core debris for examination, storage, and } \\
\text { disposal. }\end{array}$ \\
\hline DOE-Sponsor: & DOE-EM \\
\hline Drivers: & $\begin{array}{l}\text { Economic - DOE wants to reduce costs associated with maintaining the TAN } \\
\text { facility. One method is to remove the SNF from the facility and inactivate it. } \\
\text { ES\&H Vulnerability - DOE wants to eliminate SNF storage vulnerabilities, which } \\
\text { for TAN TMI are SNF stored in an aging facility with an unlined pool and other } \\
\text { design features departing from current criteria. }\end{array}$ \\
\hline Preferred Action: & $\begin{array}{l}\text { Remove and dry TMI canisters, transfer to ICPP, and place in interim storage in } \\
\text { new facility. }\end{array}$ \\
\hline Alternative Actions: & $\begin{array}{l}\text { 1) Perform dry cask storage project at TAN as originally scoped. } \\
\text { 2) Leave SNF in place and maintain facility in current status. }\end{array}$ \\
\hline Transfer Cask: & NuPac $125-8$ \\
\hline Transfers: & 342 from TAN Storage Pool, and 49 from TAN to ICPP \\
\hline Time Frame: & Transfers: Nov 97 through Nov 99 \\
\hline Prerequisites: & $\begin{array}{l}\text { 1) Write and approve applicable safety documents and procedures. } \\
\text { 2) Receive a Finding of No Significant Impact (FONSI) for TMI environmental } \\
\text { assessment (EA). } \\
\text { 3) Determine storage facility concept at ICPP. } \\
\text { 4) Complete shipper and receiver ORR. }\end{array}$ \\
\hline NEPA: & $\begin{array}{l}\text { An EA is needed for construction of a new storage facility. An above grade, } \\
\text { monolithic, vertical vault storage facility is proposed. }\end{array}$ \\
\hline Critical Issues: & $\begin{array}{l}\text { 1) Issue a FONSI for TMI EA. } \\
\text { 2) Issue fuel handling change notice. } \\
\text { 3) Construct new facility. } \\
\text { 4) Obtain suitable transport trailer. }\end{array}$ \\
\hline Est. Total Cost: & $\$ 22.762 \mathrm{M}$ \\
\hline Funded: & Yes \\
\hline Est. Pay Back Period: & 13.5 years \\
\hline Related Documents: & $\begin{array}{l}\text { EG\&G Idaho, 1994, Quick Look Study. } \\
\text { U.S. DOE, 1993, Spent Fuel Working Group Report on Inventory and Storage of } \\
\text { the Department's Spent Nuclear Fuel and Other Reactor Irradiated Nuclear } \\
\text { Materials and Their Environmental, Safety, and Health Vulnerabilities, } \\
\text { December } 1993 .\end{array}$ \\
\hline
\end{tabular}




\begin{tabular}{|c|c|}
\hline DOE Sponsor: & DOE-EM \\
\hline Preferred Action: & $\begin{array}{l}\text { Repackage the fuel, ship it to ICPP, and place in interim storage at CPP-749 Dry } \\
\text { Well Vaults, except for placing one canister (FP-2) in IFSF. }\end{array}$ \\
\hline Alternative Actions: & $\begin{array}{l}\text { 1) Include positions for LOFT SNF in TMI storage facility design. } \\
\text { 2) Dry and place in a cask on a pad at TAN as previously planned. } \\
\text { 3) Leave SNF in place and maintain facility in current status. }\end{array}$ \\
\hline Transfer Cask: & Peach Bottom-2 (PB-2) \\
\hline Transfers: & 7 \\
\hline NEPA: & $\begin{array}{l}\text { The present assessment is that this transfer is encompassed under current } \\
\text { activities. }\end{array}$ \\
\hline Critical Issues: & $\begin{array}{l}\text { The PB- } 2 \text { cask does not have a Certificate of Compliance for the U.S. Department } \\
\text { of Transportation (DOT). Preliminary discussion with DOE indicates that a DOT } \\
\text { exemption or out-of-commerce variance will be obtainable. }\end{array}$ \\
\hline Est. Total Cost: & $\$ 2.679 M$ \\
\hline Funded: & Yes - TAN Pool Stabilization Project \\
\hline Est. Pay Back Period: & 5.2 years \\
\hline Related Documents: & $\begin{array}{l}\text { U.S. DOE, 1993, Spent Fuel Working Group Report on Inventory and Storage of the } \\
\text { Department's Spent Nuclear Fuel and Other Reactor Irradiated Nuclear Materials and Their } \\
\text { Environmental, Safety, and Health Vulnerabilities, December } 1993 \text {. }\end{array}$ \\
\hline
\end{tabular}




\begin{tabular}{|c|c|}
\hline Background: & $\begin{array}{l}\text { DOE has conducted a dry storage demonstration program (Thermal Fuel Behavior } \\
\text { Project) for commercial SNF at TAN since } 1985 \text {. Low-enriched-uranium ( } 39.1 \\
\text { metric tons) was acquired from utilities processed, and installed in four dry storage } \\
\text { casks (Castor-V/21, MC-10, TN-24P, and VSC-17). The casks are on a concrete } \\
\text { pad (TAN-791) north of the TAN-607 Hot Shop. The SNF from the TN-24P and } \\
\text { the VSC-17 casks has been consolidated by separating the fuel rods from the fuel } \\
\text { assembly skeletons and placing the fuel rods in a close-packed configuration. The } \\
\text { VSC- } 17 \text { cask is unsuitable for dry storage use at ICPP, because ICPP has no dry } \\
\text { shielded facility for cask repair. } \\
\text { The remainder of the commercial SNF is located in wet storage in aluminum } \\
\text { coffins, which are potentially vulnerable to corrosion. Transfer of the SNF from } \\
\text { the coffins to dry storage in TAN- } 607 \text { is planned for FY-94 to alleviate the } \\
\text { vulnerability. }\end{array}$ \\
\hline Drivers: & $\begin{array}{l}\text { Economic - DOE wants to reduce costs associated with maintaining the facility. } \\
\text { One method is to remove the pad from service. }\end{array}$ \\
\hline DOE Sponsor: & DOE-RW/EM \\
\hline Preferred Action: & $\begin{array}{l}\text { Transport commercial casks to TAN Hot Shop, rearrange the SNF in casks, } \\
\text { transfer loaded casks to ICPP, and place in interim storage on newly constructed } \\
\text { pads near CPP-749. }\end{array}$ \\
\hline Alternative Actions: & $\begin{array}{l}\text { 1) Leave SNF in place and maintain facility in current status. } \\
\text { 2) Unload the casks, use commercial shipping casks to transfer SNF to CPP- } \\
666 \text {. Move storage casks to CPP- } 666 \text { for reloading. Place loaded casks on } \\
\text { new pads. } \\
\text { 3) Include positions for this fuel in the TMl storage facility design. }\end{array}$ \\
\hline Transfer Cask: & Ship in loaded storage cask using NuPac $125-\mathrm{B}$ to transport \\
\hline Transfers: & 3 \\
\hline Time Frame: & Transfers: Dec 99 through Jan 00 \\
\hline Prerequisites: & $\begin{array}{l}\text { 1) Construct pad at ICPP. } \\
\text { 2) Complete shipper and receiver ORR.* } \\
\text { 3) SNF Recovery Plan and procedures. } \\
\text { 4) Receive DOT exemption to ship. } \\
\text { * Both a shipper and receiver activity. }\end{array}$ \\
\hline NEPA: & A categorical exclusion $(C X)$ would be needed to construct a new pad at ICPP. \\
\hline Critical Issues: & $\begin{array}{l}\text { 1) Approval to transport loaded casks is needed. } \\
\text { 2) Should the Thermal Fuel Behavior Project be continued after the casks are } \\
\text { moved to ICPP? } \\
\text { 3) Could the Thermal Fuel Behavior Project continue meaningfully, if the fuel is } \\
\text { immersed during wet transfer at CPP-666? }\end{array}$ \\
\hline Est. Total Cost: & $\$ 3.451 \mathrm{M}$ \\
\hline Funded: & No \\
\hline Est. Pay Back Period: & 7.8 years \\
\hline Related Documents: & $\begin{array}{l}\text { U.S. DOE, 1993, Spent Fuel Working Group Report on Inventory and Storage of } \\
\text { the Department's Spent Nuclear Fuel and Other Reactor Irradiated Nuclear } \\
\text { Materials and Their Environmental, Safety, and Health Vulnerabilities, } \\
\text { December } 1993 .\end{array}$ \\
\hline
\end{tabular}




\begin{tabular}{|c|c|}
\hline Background: & $\begin{array}{l}\text { The CPP-603 basins were built and placed into operation in the early } 1950 \text { s for } \\
\text { underwater storage of irradiated nuclear fuels awaiting processing or other } \\
\text { disposition. In 1993, the three basins contained } 2899 \mathrm{~kg} \text { of uranium in a variety } \\
\text { of SNF configurations and fissionable-isotope enrichments in } 1993 \text {. The basins are } \\
\text { unlined- concrete structures. The SNF is stored in racks or on monorail hangers. } \\
\text { The SNF is being discharged from CPP-603 to comply with a U.S. District Court } \\
\text { Order issued in September } 1993 \text {. Removing SNF from CPP-603 will correct } \\
\text { perceived deficiencies, which include corrosion-damaged SNF encapsulation and } \\
\text { hangers, facility structure, resistance to seismic events, and water-leak detection. }\end{array}$ \\
\hline Drivers: & $\begin{array}{l}\text { Economic - DOE wants to reduce facility upgrade and operation costs by } \\
\text { inactivating, and D\&D of the CPP- } 603 \text { wet storage basins. } \\
\text { ES\&H Vulnerabilities - DOE wants to correct the observed vulnerabilities of SNF } \\
\text { storage in CPP-603 wet storage basins including; inadequate water leakage } \\
\text { detection, inadequate seismic resistance, corrosion damage of SNF and SNF } \\
\text { supports, and inadequate heating and ventilating system redundancy and } \\
\text { radionuclide detection. }\end{array}$ \\
\hline DOE Sponsor: & DOE-EM \\
\hline Preferred Action: & $\begin{array}{l}\text { Correct CPP-603 storage basin facility and SNF deficiencies. Relocate } 189 \text { FHU's } \\
\text { from North Basin to CPP- } 666 \text { by December } 31,1994 \text {. Transfer an additional } 189 \\
\text { FHUs to CPP-666 by December } 31,1995 \text {. Transfer an additional } 244 \text { FHUs to } \\
\text { CPP-666 by December } 31,1996 \text {. Acquire capability for recanning SNF. Transfer } \\
\text { the South Basin fuel ( } 755 \text { positions) to CPP-666 by December } 31,2000 \text {. }\end{array}$ \\
\hline Alternative Actions: & $\begin{array}{l}\text { The U.S. District Court Order restrains consideration of alternate approaches, but } \\
\text { state concurrence is being pursued to store some South Basin fuels in IFSF. }\end{array}$ \\
\hline Transfer Cask: & STR Charger \\
\hline Transfers: & -1200 \\
\hline Time Frame: & Transfers: Mar 94 through Dec 00 \\
\hline Prerequisites: & $\begin{array}{l}\text { 1) Updates to CPP- } 666 \text { PSD approved fuels list. } \\
\text { 2) Write handling procedures. } \\
\text { 3) Perform multiple Readiness Assessments. } \\
\text { 4) Design and fabricate handling tools and storage buckets. }\end{array}$ \\
\hline NEPA: & Task actions are already approved. \\
\hline Critical Issues: & None \\
\hline Est. Total Cost: & $\$ 10.490 \mathrm{M}$ \\
\hline Funded: & Yes (Activity Data Sheet 1010) \\
\hline Est. Pay Back Period: & 8.7 years \\
\hline Related Documents: & $\begin{array}{l}\text { H. L. Ryan (Sr. U.S. District Court Judge), Order Modifying Order of } \\
\text { June } 28,1993 \text { dated September } 28,1993 . \\
\text { U.S. DOE, 1993, Spent Fuel Working Group Report on Inventory and Storage of } \\
\text { the Department's Spent Nuclear Fuel and Other Reactor Irradiated Nuclear } \\
\text { Materials and Their Environmental, Safety, and Health Vulnerabilities, } \\
\text { December } 1993 . \\
\text { Buckland, R. J. et al, INEL D\&D Long Range Plan, October } 1993 . \\
\text { Task Team Report Accelerated Fuel Transfers from CPP-603 to CPP-666, dated } \\
\text { October 29, 1993. }\end{array}$ \\
\hline
\end{tabular}


Table 2.4-9 WBS B02 - Rover-Bed Material Repackaging and Transfer to CPP-749

\begin{tabular}{|c|c|}
\hline Background: & $\begin{array}{l}\text { The CPP-640 facility contains the headend processing systems for the Rover } \\
\text { rocket carbon-encapsulated SNF and stainless steel clad SNF. The fluidized-bed } \\
\text { burning stage of the Rover SNF processing system, which was shutdown in 1984, } \\
\text { contains a TBD quantity of uranium-containing ash. The facility is on the DOE } \\
\text { Surplus Facilities List. }\end{array}$ \\
\hline Drivers: & $\begin{array}{l}\text { Economic - DOE wants to reduce facility upgrade and operation costs by } \\
\text { inactivating and } D \& D \text { the CPP- } 640 \text { wet-storage basins. }\end{array}$ \\
\hline & $\begin{array}{l}\text { ES\&H Vulnerabilities - DOE wants to correct the observed vulnerabilities of SNF } \\
\text { storage in CPP- } 640 \text { including inadequate leak protection of the piping systems. }\end{array}$ \\
\hline DOE Sponsor: & DOE-EM \\
\hline Preferred Action: & $\begin{array}{l}\text { Determine the quantity of uranium and ash, satisfy regulation compliance } \\
\text { requirements, and acquire canisters for storage in CPP-749 drywells. }\end{array}$ \\
\hline Alternative Actions: & $\begin{array}{l}\text { 1) Leave SNF in place and maintain facility in current status, in hope that } \\
\text { reprocessing SNF to separate the SNM from the hazardous high-level waste } \\
\text { will be resumed for compliance to ALARA regulations. } \\
\text { 2) Transfer the bed material to an interim storage facility as transuranic high-level } \\
\text { waste after an appropriate authority defines conditions for exemption from the } \\
\text { legal definitions and preservation-stipulations for SNF. }\end{array}$ \\
\hline Transfer Cask: & $\begin{array}{l}\text { Rover Transport Cask from CPP-640 to ICPP-IFSF } \\
\text { PB-2 from ICPP-IFSF to CPP-749 }\end{array}$ \\
\hline Transfers: & $\begin{array}{l}12 \text { from CPP-640 to ICPP-IFSF } \\
3 \text { from ICPP-IFSF to CPP-749 }\end{array}$ \\
\hline Time Frame: & Transfers: July 97 through Aug 97 \\
\hline Prerequisites: & $\begin{array}{l}\text { 1) Material is canned at CPP- } 640 \text { prior to transfer to IFSF. } \\
\text { 2) An ORR has been successfully completed for restart of ICPP SNF dry-storage } \\
\text { facilities. }\end{array}$ \\
\hline NEPA: & A CX would be sufficient. \\
\hline Critical /ssues: & Difficult to recover SNM from process lines and equipment. \\
\hline Est. Total Cost: & $\$ 0.856 \mathrm{M}$ (transfer cost only) \\
\hline Funded: & Proposed \\
\hline Est. Pay Back Period: & 0.2 years \\
\hline Related Documents: & Buckland, R. J. et al, INEL D\&D Long Range Plan, October 1993. \\
\hline
\end{tabular}




\begin{tabular}{|c|c|}
\hline Background: & $\begin{array}{l}\text { The CPP- } 749 \text { facility was constructed to provide dry storage of chemically-reactive } \\
\text { SNF for an indefinite period now believed to extend until CY- } 2014 \text {. Two } \\
\text { generations of drywells (vaults) have been constructed. There are } 831 \text { st- } \\
\text { generation drywells and } 1352 \text { nd-generation drywells. The } 1 \text { st-generation drywells } \\
\text { extend } 20 \mathrm{ft} \text { below grade and include a carbon-steel casing sealed at the top with } \\
\text { a concrete plug and carbon steel cap and sealed at the bottom with cement grout. } \\
1.6 \text { metric tons of stainless steel clad, highly-enriched uranium from Fermi is } \\
\text { stored in fourteen of the } 1 \text { st-generation drywells and } 34.2 \text { metric tons of carbon- } \\
\text { encapsulated low-enriched uranium from Peach Bottom is stored in } 45 \text { of the } 1 \text { st- } \\
\text { generation drywells. } \\
\text { The } 1 \text { st-generation drywells may be susceptible to corrosion and do not include } \\
\text { provisions for determining the condition of the drywell or the SNF stored in the } \\
\text { drywell. }\end{array}$ \\
\hline Drivers: & $\begin{array}{l}\text { Economic - None } \\
\text { ES\&H Vulnerabilities - DOE wants to correct the observed vulnerabilities of SNF } \\
\text { storage in CPP-749 } 1 \text { st-generation drywells including; inadequate water leakage } \\
\text { detection, and corrosion damage of drywell structures and SNF. }\end{array}$ \\
\hline DOE Sponsor: & DOE-EM \\
\hline Preferred Action: & $\begin{array}{l}\text { Satisfy regulatory compliance requirements, and acquire equipment (handling tools, } \\
\text { leak-test rig, and canisters for storage of Peach Bottom SNF in CPP-749 drywells. } \\
\text { Transfer Peach Bottom SNF to ICPP-IFSF for recanning. Transfer recanned Peach } \\
\text { Bottom SNF to CPP-749 2nd-generation drywells. Transfer Fermi SNF from 1st- } \\
\text { generation to 2nd-generation drywells at CPP-749. }\end{array}$ \\
\hline Alternative Actions: & $\begin{array}{l}\text { 1) Leave SNF in place and maintain facility in current status in hope that } \\
\text { reprocessing SNF to separate the SNM from the hazardous high-level waste } \\
\text { will be resumed for compliance to ALARA regulations. } \\
\text { 2) Transfer the SNF to an interim storage facility as transuranic high-level waste } \\
\text { after an appropriate authority defines conditions for exemption from the legal } \\
\text { definitions and preservation stipulations for SNF. }\end{array}$ \\
\hline Transfer Cask: & PB-2 \\
\hline Transfers: & $\begin{array}{l}45 \text { from CPP-749 } 1 \text { st-generation drywells to ICPP-IFSF } \\
45 \text { from ICPP-IFSF to CPP-749 2nd-generation drywells } \\
14 \text { between CPP-749 } 1 \text { st and 2nd-generation drywells }\end{array}$ \\
\hline Time Frame: & Transfers: Oct 95 through Aug 97 \\
\hline Prerequisites: & $\begin{array}{l}\text { 1) Tooling to package fuel for storage in CPP- } 749 \text { available in IFSF. } \\
\text { 2) Complete ORR for restart of ICPP SNF dry storage facilities. }\end{array}$ \\
\hline NEPA: & A CX would be needed. \\
\hline Critical Issues: & None \\
\hline Est. Total Cost: & $\$ 4.560 \mathrm{M}$ \\
\hline Funded: & Proposed \\
\hline Est. Pay Back Period: & TBD \\
\hline Related Documents: & $\begin{array}{l}\text { U.S. DOE, 1993, Spent Fuel Working Group Report on Inventory and Storage of } \\
\text { the Department's Spent Nuclear Fuel and Other Reactor Irradiated Nuclear } \\
\text { Materials and Their Environmental, Safety, and Health Vulnerabilities, } \\
\text { December 1993. } \\
\text { Buckland, R. J. et al, INEL D\&D Long Range Plan, October } 1993 .\end{array}$ \\
\hline
\end{tabular}




\begin{tabular}{|c|c|}
\hline Background: & $\begin{array}{l}\text { ARMF/CFRMF SNF will be temporarily stored in CPP-IFSF after the consolidation } \\
\text { transfer for conduct of dry storage demonstration. When the dry storage process } \\
\text { is shown to be satisfactory, the ARMF/CFRMF SNF will be transferred to the } \\
\text { CPP-749 drywells to improve the security of the SNM constituent of the SNF. }\end{array}$ \\
\hline Drivers: & $\begin{array}{l}\text { Economic - None } \\
\text { ES\&H Vulnerabilities - DOE may want to assure that the dry storage configuration } \\
\text { of the consolidation SNF will not create additional vulnerability conditions. }\end{array}$ \\
\hline DOE Sponsor: & TBD \\
\hline Preferred Action: & $\begin{array}{l}\text { Improve safeguards for storage of the SNM constituent of the ARMF/CFRMF SNF } \\
\text { by transferring the SNF to CPP-749 drywells after completion of a successful dry } \\
\text { storage demonstration program in ICPP-IFSF. }\end{array}$ \\
\hline Alternative Actions: & $\begin{array}{l}\text { 1) Extend the storage of the ARMF/CFRMF SNF in ICPP-IFSF after completing the } \\
\text { dry storage demonstration plan. } \\
\text { 2) Transfer the SNF to an interim storage facility as transuranic high-level waste } \\
\text { after an appropriate authority defines conditions for exemption from the legal } \\
\text { definitions and preservation-stipulations. }\end{array}$ \\
\hline Transfer Cask: & PB-2 \\
\hline Transfers: & 2 \\
\hline Time Frame: & Preps: Jun 99 through Oct $99 \quad$ Transfers: Oct 99 through Nov 99 \\
\hline Prerequisites: & $\begin{array}{l}\text { 1) Tooling to package fuel for storage in CPP-749 available in IFSF. } \\
\text { 2) A successful demonstration of dry storage of the ARMF/CFRMF SNF in ICPP- } \\
\text { IFSF. }\end{array}$ \\
\hline NEPA: & A CX will be sufficient. \\
\hline Critical Issues: & None \\
\hline Est. Total Cost: & $\$ 0.837 \mathrm{M}$ \\
\hline Funded: & No \\
\hline Est. Pay Back Period: & TBD \\
\hline Related Documents: & $\begin{array}{l}\text { D. L. Hamer letter to W.C. Moffitt, OPE-SNF-WJM-93067, Program Execution } \\
\text { Guidance for Site Fuel Consolidation, dated December 29, } 1993 .\end{array}$ \\
\hline
\end{tabular}




\begin{tabular}{|c|c|}
\hline Background: & $\begin{array}{l}\text { The CPP-603 Fuel Element Cutting Facility (FECF) was constructed in } 1957 \text { for } \\
\text { preparing SNF for processing. The facility is a typical hot cell configuration with } \\
5 \text {-ft thick concrete walls, shielded-viewing windows, manipulators, and interior } \\
\text { lighting. The facility was shutdown in } 1980 \text { with two Peach Bottom SNF } \\
\text { segments inside. The full size Peach Bottom fuel elements contain about } 2.1 \mathrm{~kg} \text { of } \\
\text { heavy metal. The manipulators and interior lighting are currently inoperative. The } \\
\text { facility is on the DOE surplus facilities list. }\end{array}$ \\
\hline Drivers: & $\begin{array}{l}\text { Economic - DOE wants to reduce facility upgrade and operation costs by } \\
\text { inactivating and D\&D the CPP- } 603 \text { FECF. } \\
\text { ES\&H Vulnerabilities - Possible degraded Peach Bottom fuel. }\end{array}$ \\
\hline DOE Sponsor: & DOE-EM \\
\hline Preferred Action: & $\begin{array}{l}\text { Recover the two Peach Bottom SNF segments from CPP- } 603 \text { FECF and transfer } \\
\text { them to ICPP IFSF for canning and storage. }\end{array}$ \\
\hline Alternative Actions: & $\begin{array}{l}\text { 1) Expand the program to include execution of the recovery, canning, and } \\
\text { storage actions. } \\
\text { 2) Leave SNF in place and maintain facility in current status in hope that } \\
\text { reprocessing SNF to separate the SNM from the hazardous high-level waste } \\
\text { will be resumed for compliance to ALARA regulations. } \\
\text { 3) Recover and transfer the SNF to an interim storage facility as transuranic high- } \\
\text { level waste after an appropriate authority defines conditions for exemption } \\
\text { from the legal definitions and preservation stipulations for SNF. }\end{array}$ \\
\hline Transfer Cask: & PB-2 \\
\hline Transfers: & 1 or 2 \\
\hline Time Frame: & Preps: May 94 through Oct 95 \\
\hline Prerequisites: & Tooling to package fuel for storage in CPP-749 available in IFSF. \\
\hline NEPA: & A CX will be sufficient. \\
\hline Critical Issues: & $\begin{array}{l}\text { Task may be technically difficult due to inoperative manipulator and lighting } \\
\text { systems. }\end{array}$ \\
\hline Est. Total Cost: & $\$ 0.066 \mathrm{M}$ \\
\hline Funded: & Yes (Activity Data Sheet 1010) \\
\hline Est. Pay Back Period: & TBD \\
\hline Related Documents: & $\begin{array}{l}\text { U.S. DOE, 1993, Spent Fuel Working Group Report on Inventory and Storage of } \\
\text { the Department's Spent Nuclear Fuel and Other Reactor Irradiated Nuclear } \\
\text { Materials and Their Environmental, Safety, and Health Vulnerabilities, } \\
\text { December } 1993 . \\
\text { Buckland, R. J. et al, INEL D\&D Long Range Plan, October } 1993 .\end{array}$ \\
\hline
\end{tabular}




\subsection{PRIORITIZATION METHODOLOGY fOr SNF/SNM CONSOLIDATION TRANSFERS}

The priority of SNF/SNM transfers is driven by several interrelated factors. Some of the key factors include safety (reduced risks for stakeholders), funding (reduced capital and operating dollars), environmental protection, regulatory compliance, and public perception.

A multi-variant, decision-making analysis was used to determine the transfer priority for each SNF or SNM inventory stored at the INEL. Table 2.5-1

presents the subjective INEL SNF/SNM prioritization (decision analyses) matrix for this plan. It is a combination of strategies from WIN-367, the Spent Fuel Working Group Report on Inventory and Storage of the Department's Spent Nuclear Fuel and 0ther Reactor Irradiated Nuclear Materials and Their Environmental, Safety, and Health Vulnerabilities, and the draft INEL RiskBased Prioritization Program.

Each category has a weighted value range (0-10). Nine INEL SNF storage facilities and the subsequent proposed transfers were given a subjective score for each criterion based on informed opinions from the Task Team and other knowledgeable personnel. The final score is determined by multiplying the weighted factor times the subjective score, which also had a range 0 to 10 . Each of these individual products is then subtotaled in the "resource" and "benefits" sections, which are combined for a final total. Thus, the transfer of SNF or SNM that produced the most gain for the least amount of resources was the first to be scheduled for transfer. A short discussion of each criterion follows. The highest final total score is the first SNF to be transferred.

\section{Resource Requirement:}

Amount of SNF Transferred - How large and diverse is the inventory? Are multiple casks required for the transfer? Will the inventory require repackaging or characterization prior to transfer? A high score would indicate minimal resources are required, e.g., minimal transfers, no repackaging or characterization, casks are available, etc.

Availability of new storage for transferred SNF - Is the new storage space available for this inventory? Will the transfer consume all of this storage space or only a small part? A high score would indicate that no new construction is required and that the transfer did not require a significant amount of the available storage space.

NEPA, SAR, and special permits - Is the proposed transfer routine or does it require additional support and analys is to obtain the required approvals? A high score would indicate a routine transfer with no additional analysis.

Near-term funding - How much funding is required to implement the transfer? Is the funding Tevel or peaked? A high score would indicate minimal funding at consistent levels. 
Table 2.5-1 INEL SNF/SNM Transfer Prioritization Matrix

\begin{tabular}{|c|c|c|c|c|c|c|c|c|c|c|c|c|c|c|}
\hline \multirow{3}{*}{ 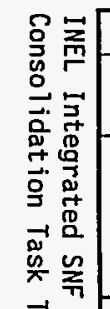 } & & \multicolumn{7}{|c|}{ Resource Requirements } & \multicolumn{4}{|c|}{ Benefits } & & \\
\hline & $\begin{array}{l}\text { Weighted } \\
\text { Factor }\end{array}$ & 3 & 2 & 7 & 5 & 5 & 5 & $2 z$ & 10 & 9 & 8 & \% & & \\
\hline & & $\begin{array}{c}\text { Amount of } \\
\text { Transferred } \\
\text { SNF } \\
\end{array}$ & $\begin{array}{c}\text { Availability } \\
\text { Of New } \\
\text { Storage }\end{array}$ & $\begin{array}{c}\text { NEPA, SAR, and Special } \\
\text { Permits } \\
\end{array}$ & \begin{tabular}{|c|} 
Available \\
Near- \\
Term \\
Funding \\
\end{tabular} & \begin{tabular}{|c|} 
Equipment, \\
Time, \\
Personnel \\
etc.
\end{tabular} & $\begin{array}{c}\text { Schedule } \\
\text { Constraints } \\
\end{array}$ & $\begin{array}{l}\text { Sub } \\
\text { Total } \\
\end{array}$ & $\begin{array}{c}\text { Reduction } \\
\text { Of Safety \& } \\
\text { Env. Risk } \\
\end{array}$ & \begin{tabular}{|c}
$\begin{array}{c}\text { Reduction } \\
\text { Of Political } \\
\text { Risk }\end{array}$ \\
\end{tabular} & \begin{tabular}{|c|} 
Less \\
Facility \\
Life-Cycle \\
Costs \\
\end{tabular} & $\begin{array}{l}\text { Sub } \\
\text { Total }\end{array}$ & $\begin{array}{l}\text { Final } \\
\text { Total }\end{array}$ & $\begin{array}{c}\text { Final } \\
\text { Priority }\end{array}$ \\
\hline 挡 & PBF Canal & 7 & 8 & 8 & 5 & 6 & 5 & 173 & 3 & 4 & 9 & 138 & 311 & 5 th \\
\hline 要 & & & & & & & & & & & & & & \\
\hline & CPP-603 & 2 & 8 & 6 & 10 & 3 & 4 & 149 & 10 & 10 & 8 & 254 & 403 & 1st \\
\hline & CPP.749 & 5 & 8 & 9 & 9 & 6 & 5 & 194 & 8 & 7 & 2 & 159 & 353 & 3rd \\
\hline & Rover Bed & 9 & 8 & 8 & 7 & 7 & 5 & 194 & 7 & 4 & 10 & 186 & 380 & 2nd \\
\hline & & & & & & & & & & & & & & \\
\hline & $\begin{array}{c}\text { TRA-621 } \\
\text { NMIS }^{\star}\end{array}$ & 8 & 9 & 7 & 6 & 8 & 8 & 201 & 1 & 3 & 7 & 93 & 294 & 6th \\
\hline & $\begin{array}{c}\text { TRAMTR } \\
\text { Canal }\end{array}$ & 5 & 8 & 6 & 5 & 4 & 5 & 143 & 9 & 8 & 4 & 194 & 337 & 4th \\
\hline$\underset{\omega}{\omega}$ & $\begin{array}{c}\text { TRA-660 } \\
\text { ARMF/ CFRMF }\end{array}$ & 8 & 8 & 8 & 5 & 8 & 5 & 186 & 5 & 6 & 4 & 136 & 322 & 5th \\
\hline & TAN TMI** & 3 & 3 & 3 & 8 & 3 & 9 & 136 & 6 & 9 & 8 & 205 & 364 & 3rd \\
\hline & TAN LOFT ${ }^{\star *}$ & 9 & 8 & 5 & 8 & 8 & 8 & 198 & 6 & 9 & 6 & 189 & 364 & 3rd \\
\hline & Commerclal & 7 & 4 & 3 & 2 & 6 & 9 & 135 & 2 & 2 & 6 & 86 & 221 & 7th \\
\hline & & & & & & & & & & & & & & \\
\hline & & & & & & & & & & & & & & \\
\hline & & & & & & & & & & & & & & \\
\hline & & & & & & & & & & & & & & \\
\hline & & & & & & & & & & & & & & \\
\hline N & & & & & & & & & & & & & & \\
\hline $\mathscr{D}$ & & & & & & & & & & & & & & \\
\hline & & & & & & & & & & & & & & \\
\hline & & & & 0 & $7-18$ & Sis & 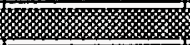 & 挤- & 10 & & & & & \\
\hline 10 & & & & Worst & & & & & Best & & & & & \\
\hline & " Cold unirriad & liated ATR Fu & & & & & & & & & & & & \\
\hline$\infty$ & "** These SNF & are moved to & gether. Th & the final total is an average & of the two & totals for eacl & h fuel. & & & & & & & \\
\hline
\end{tabular}


Equipment, Time, and Personnel, etc. - Does the transfer use existing resources or is it necessary to purchase new equipment and hire and train new personnel? A high score would indicate use of existing resources and minimal new construction.

Schedule constraints - Can the receiving ICPP accept the inventory as soon as the shipper is prepared to implement the transfer? If not, how long is the delay? A high score would indicate no receiver delay.

\section{Benefit:}

Reduction of safety and environmental risk - For the purpose of this plan, the DOE-HQ ES\&H SNF storage vulnerability results were used to rate the SNF storage facilities at the INEL. The safety and environmental risks were assumed to be essentially the same for severe accidents and extreme abnormal events. However, for routine operations the environmental concerns may be more controlling. The receiving facility must not increase its SNF storage risk if the overal1 INEL risk is to be reduced. A high score for this area indicates that the transfer has significantly reduced the ES\&H risk. A probabilistic risk assessment of each INEL SNF shipper and receiver storage facility would provide a more comprehensive perspective on which fuel should be moved first. The "before" and "after" risk levels for each SNF storage facility would also provide insight on how to lower the overal7 INEL SNF storage risk the fastest. However, this type of analysis was not possible due to time and funding constraints. Thus, the collective judgement of the task team was utilized to appraise these issues.

Reduced political risk - SNF issues driven by court orders were deemed to have higher political risk than SNF that is not controlled by these legal directives. A high score would indicate that the "after" political risk has been significantly reduced.

Reduced facility life-cycle costs - Retirement of older SNF and SNM storage facilities will certainly reduce storage costs, but some radiological control cost will remain until the facility is decommissioned. A high score would indicate that the life-cycle costs have been significantly reduced.

Unfortunately, objective and complete data for all of these key factors are not available for every potential SNF transfer. The near-term and facility life-cycle cost data presented in this table are based on the best available information (see section 3.0). Obviously, low near-term funding requirements with short recovery time and high facility life-cycle savings would be desirable for every transfer. However, some safety issues may result in priority transfers. Thus, many trade-off analyses must be considered with al1 of the stakeholders before a final path forward can be selected. Table 2.5-1 represents the Task Team's best effort to include all of these drivers in a bal anced format. 


\subsection{PROPOSED CONSOLIDATION SCHEDULE}

As previously stated, the principal purpose of this Task Team was to develop a detailed and integrated INEL SNF consolidation plan. The plan includes schedules and costs to transfer INEL SNF to ICPP as soon as possible. The result of this effort is a report (individual cost accounts, work packages, basis for estimates) that, when printed, is about 2,000 pages, contains about 6,000 tasks, 8,000 logic-ties, and 26,100 individual resource calls. Obviously, this amount of information is not "user friendly" without summary overviews. Thus, the following subsections are provided to identify the key issues and summarize the results.

Open $P T a n^{\text {TM }}$ is a software package produced by Welcom Software Technology. It is a comprehensive project planning, scheduling, cost control, and resource management tool. INEL SNF consolidation activities are entered in the open $\mathrm{P} T a \mathrm{n}^{\mathrm{TM}}$ system. Open Plan ${ }^{\mathrm{MM}}$ can then be used to analyze and model different planning strategies. Use of Open PTan ${ }^{T M}$ provided other deliverables, such as histograms of different resources on time (week, month, year) basis, to help assess resource shortfalls and consider planning options to level any peak demands.

The base case is presented first (Figure 3.0-1), and then three perturbations to the base case are discussed. These perturbations identify the impacts of funding delays and alternative consolidation strategies. This information is provided to assess the impacts of these potential developments and to heip understand the trade-off issues that relate to the best path forward for implementing INEL SNF consolidation.

\subsection{BASE CASE}

Once the basic SNF transfer scenario was developed, (see section 2.3 for base case discussion) the next step was to determine how soon the shipper and receiver could be ready to transfer the SNF. This process identified the receiver preparations as the limiting activity for initiating the SNF transfers to the IFSF. (Shipper preparations, however, are the limiting step for the TAN transfers).

The IFSF cannot receive SNF until an adapter plate is designed and fabricated for the transfer cart so it can interface with the TFBP-2 cask. This activity is a key critical path item for consolidation activities at the IFSF. Once this modification is complete, the best time to receive fuel at the IFSF was determined to be after a new dry canning station is installed, and before SNF transfers from the CPP-603 south basin began. These conditions identified a preferred SNF transfer window that started in early FY-96 and ended in late FY-97.

Figure 3.1-1 shows this SNF transfer window (shaded area) and all other related SNF activities scheduled for the IFSF. The shaded window identifies a period when other competing IFSF activities are expected to be minimal, and therefore, a preferred target for SNF transfers. The planning bars identify the length of time required to complete each of the SNF consolidation programs. However, the planning bars for some of the other activities, simply 


\section{SNF Consolidation Summary Schedule}

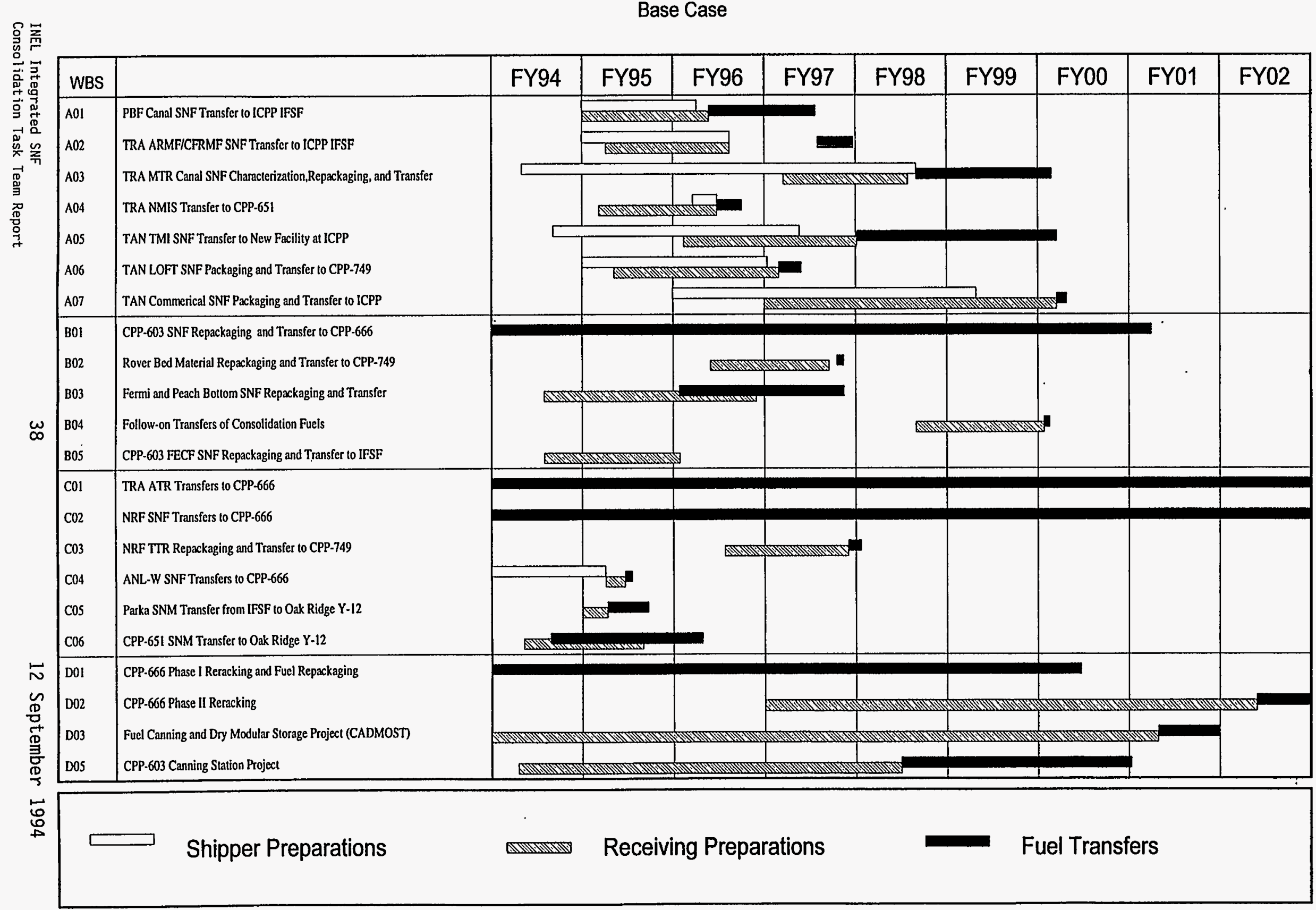

Figure 3.0-1 SNF/SNM Consolidation Schedule 


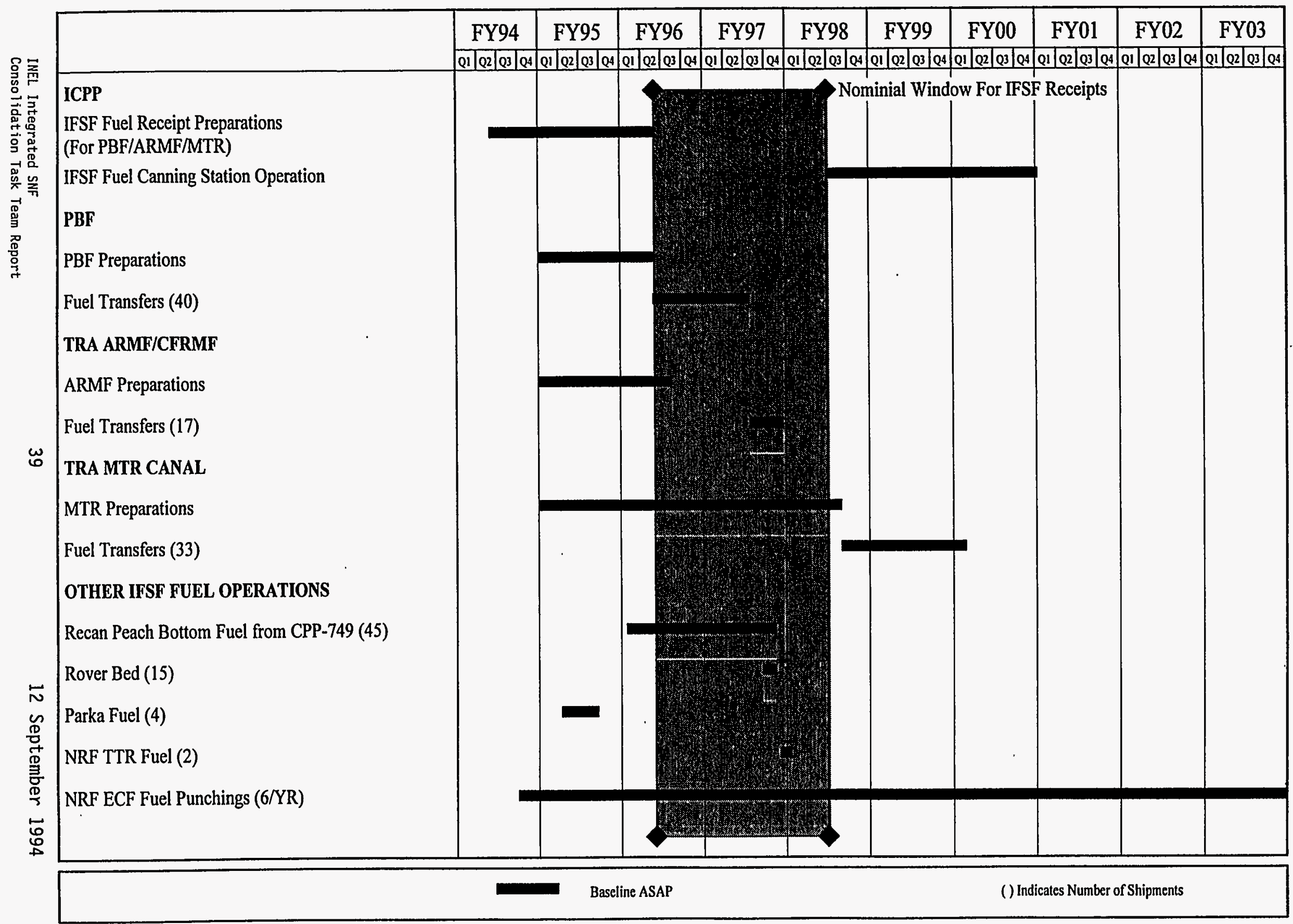

Figure 3.1-1 Base Case - IFSF SNF Consolidation Activities 
indicate continuing transfer during that time. For example, Expended Core Facility fuel punchings require minimal transfers, even though they are scheduled to occur for several years. The actual number of transfers is shown on the left side of the figure. Thus, the higher the transfer activity within the IFSF for other tasks, the more difficult it becomes to find time for the SNF consolidation transfers.

The IFSF receipt window (Figure $3.1-1$ ) is not intended to imply that SNF receipts cannot occur after this time frame. In fact, the MTR canal receipts must occur outside the window because they can not be prepared for transfer any sooner. SNF receipts before the window opens are not possible because the IFSF transfer cart is not ready for the TBFP-2 cask.

Conducting transfers after the window closes generally requires more time per transfer, which increases the consolidation schedule, cost, and time to recover the transfer cost. The next window would begin when the CPP-603 south basin transfers are completed in December 2000. It should also be recognized that if the CPP-603 south basin SNF transfers start sooner, then the transfer window will shorten accordingly, and the CPP-603 south basin completion date will occur earlier. Parallel transfers from CPP-603 south basin and PBF and ATR to the IFSF are possible. Their schedule impacts are discussed in section 3.2 .

The shipper and receiver costs for the proposed WBS AO series are summarized on an annual basis in Table 3.1-1. The shipper costs include the SNF transfer charges to ICPP. Detailed breakdown of these costs to the individual work package and event level was completed. An example of this level of detail is provided in Appendix D for the MTR canal transfers. Table 3.1-1 also identifies the annual operating savings for each storage facility, and the number of years required to recover consolidation costs based on savings.

From an overall programmatic perspective, the total new funding required to implement the $A O$ and $B O$ WBS activities is about $\$ 25.2 \mathrm{M}$. The time to recover these transfer costs is about 6.4 years. The time to recover the entire funding for the AO and BO WBS activities is about 6 years. These recovery times could be reduced even further, if the facilities with higher operating costs are retired first. However, this strategy would increase the SNF storage risk for the older facilities for which retirement is postponed.

Figure 3.1-2 presents the required funding profile for the proposed base case SNF consolidation $p 1$ an. The upper line represents the total funding required to implement all of the $A O$ and BO WBS elements previousiy identified in Section 1.4 (see Tables 1.4-1 and -2). Some of these activities are funded and underway, and others are not funded. The lower line in Figure 3.1-2 depicts the new or rescheduled funding required to implement the remaining parts of the SNF consolidation package. The peaks in the funding profile reflect on-going transfer activity between CPP-603 and CPP-666. The new or unfunded budget is 38\% of the total consolidation costs and wi17 on $7 y$ require about $\$ 6 \mathrm{M} / \mathrm{yr}$. of additional funding which is only about half of the projected annual savings rate. 
Table 3.1-1 INEL SNF Consolidation Costs Summary

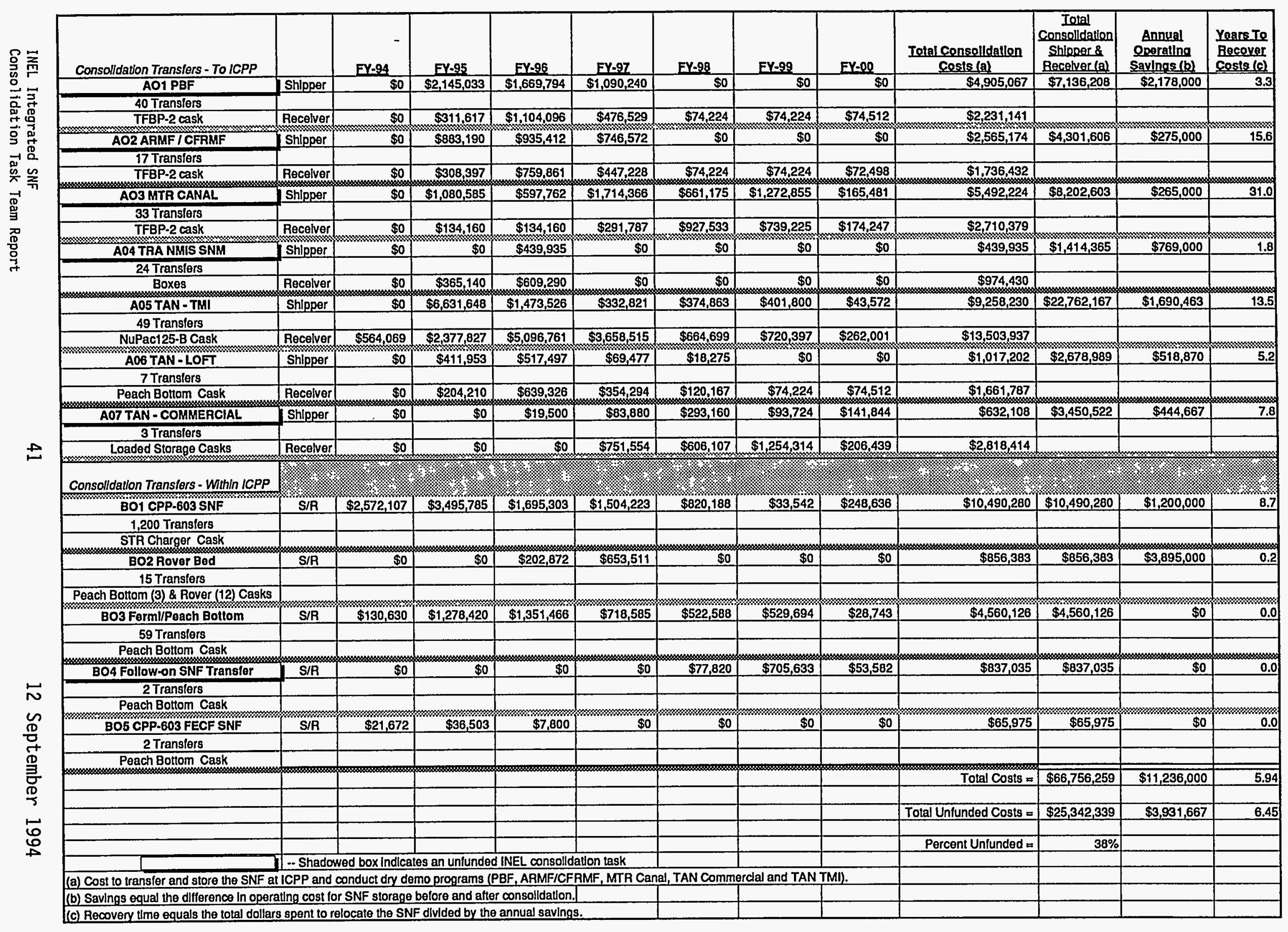




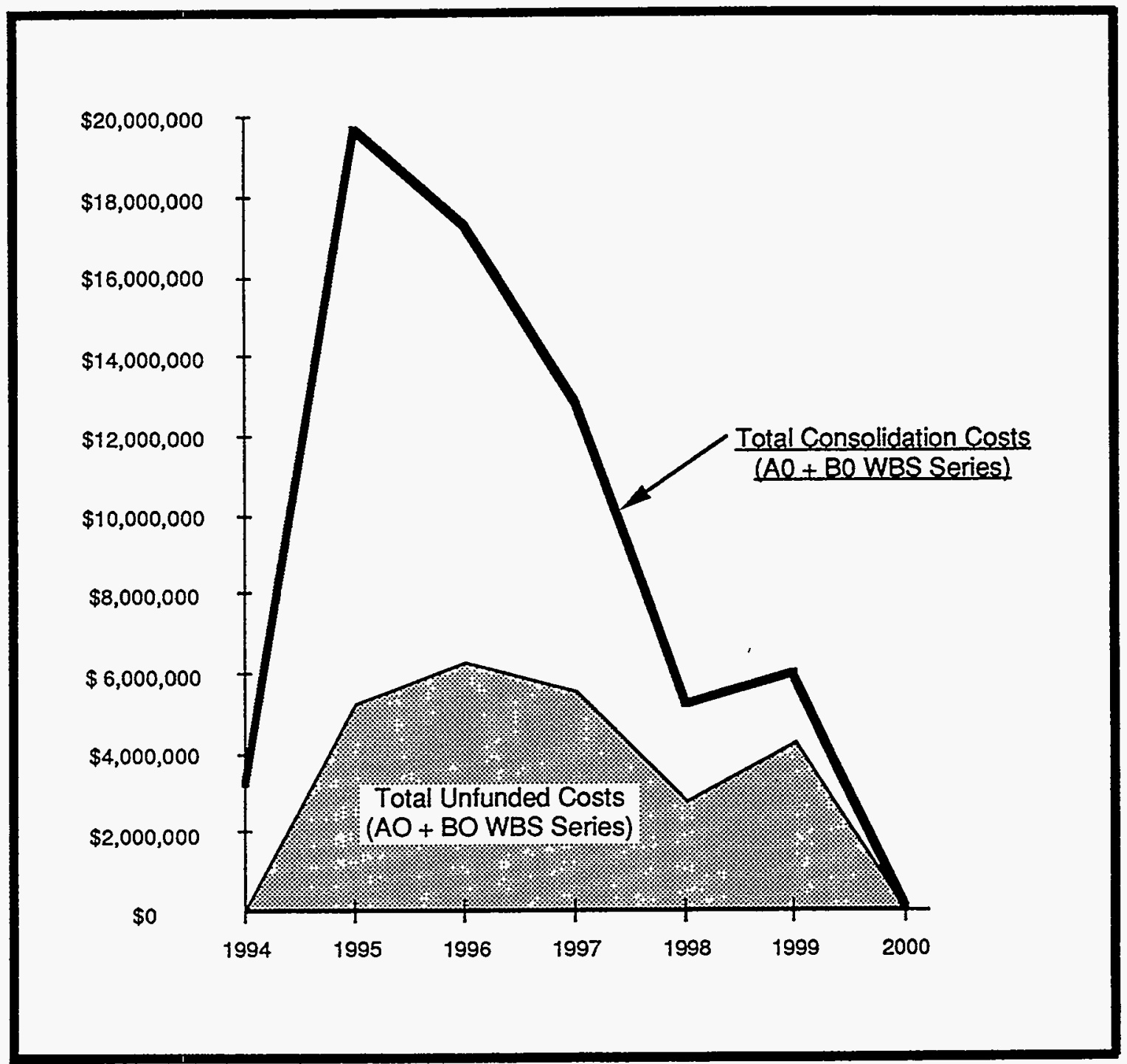

Figure 3.1-2 Base Case Cost Profiles for INEL SNF Consolidation (Funded vs Unfunded) 


\subsection{PERTURBATIONS OF THE BASE CASE}

The number of possible alternatives to the consolidation as soon as possible base case is unlimited. Three perturbations were selected to demonstrate the usefulness of this planning model and address some logical "what if" questions. The ability to analyze and respond to these or any other new scenario is significantly enhanced by the techniques developed by the Task Team. The impacts of new SNF receipts can also be evaluated once their resource requirements are added to the existing plan.

This type of planning model should prove to be especialty beneficial as national SNF management options are analyzed for their impact on the INEL site specific SNF issues. Impacts from changes to the CPP-666/CPP-603 transfer schedule and the TAN SNF transfers can also be evaluated. However, because the CPP-603 to CPP-666 transfers and TMI dry storage programs are already funded and underway, the SNF transfers to the IFSF presented the most potential for funding delays, and most complicated SNF interface and schedule issues. The following three alternative cases were identified to address issues related to funding delays, safety drivers, and schedule constraints.

Case A) Funding Delays - Funding is delayed for new transfers to IFSF from FY-95 unti1 FY-96, see Figure 3.2-1.

Case B) Safety Drivers - MTR canal funded in FY-95; remaining new transfers to IFSF are funded in FY-96; and funding for the design and construction of the SNF canister, IFSF transfer cart modifications, and the TFBP-2 cask maintenance are provided in FY-95, see Figure 3.2-2.

Case C) Tighter Schedule Constraints/CTosed SNF Transfer Window - IFSF receiving window is deleted because high priority SNF transfers (e.g., SNF from CPP-603 south basin) to IFSF start as soon as the IFSF canning station is completed, see Figure 3.2-3.

\subsubsection{Case A--Funding Delays}

The basic impacts of funding delays for the IFSF transfers are extended transfer time and its related cost, and extended operational cost for the delay in closing the facility operation. Table 3.2-1 summarizes these impacts.

The one year delay in funding requires SNF transfers from ARMF/CFRMF to IFSF to start after the CPP-603 south basin SNF transfers to the IFSF canning station have started. Thus, each transfer requires more time (fuel transfer bar in Figure 3.2-1 is more than twice as long), because the IFSF is not always available. The impact on the MTR canal and PBF SNF is zero, because the MTR canal and PBF SNF transfer times remain unchanged from the base case. The additional total operational time is 4 months for ARMF/CFRMF SNF, 10 months for PBF SNF, and 10 months for MTR canal SNF. Additional costs are incurred because of the delayed funding. Consolidation costs as well as facility operating costs are increased. The additional costs for Case $A$ are $\$ 3.5 M$. 


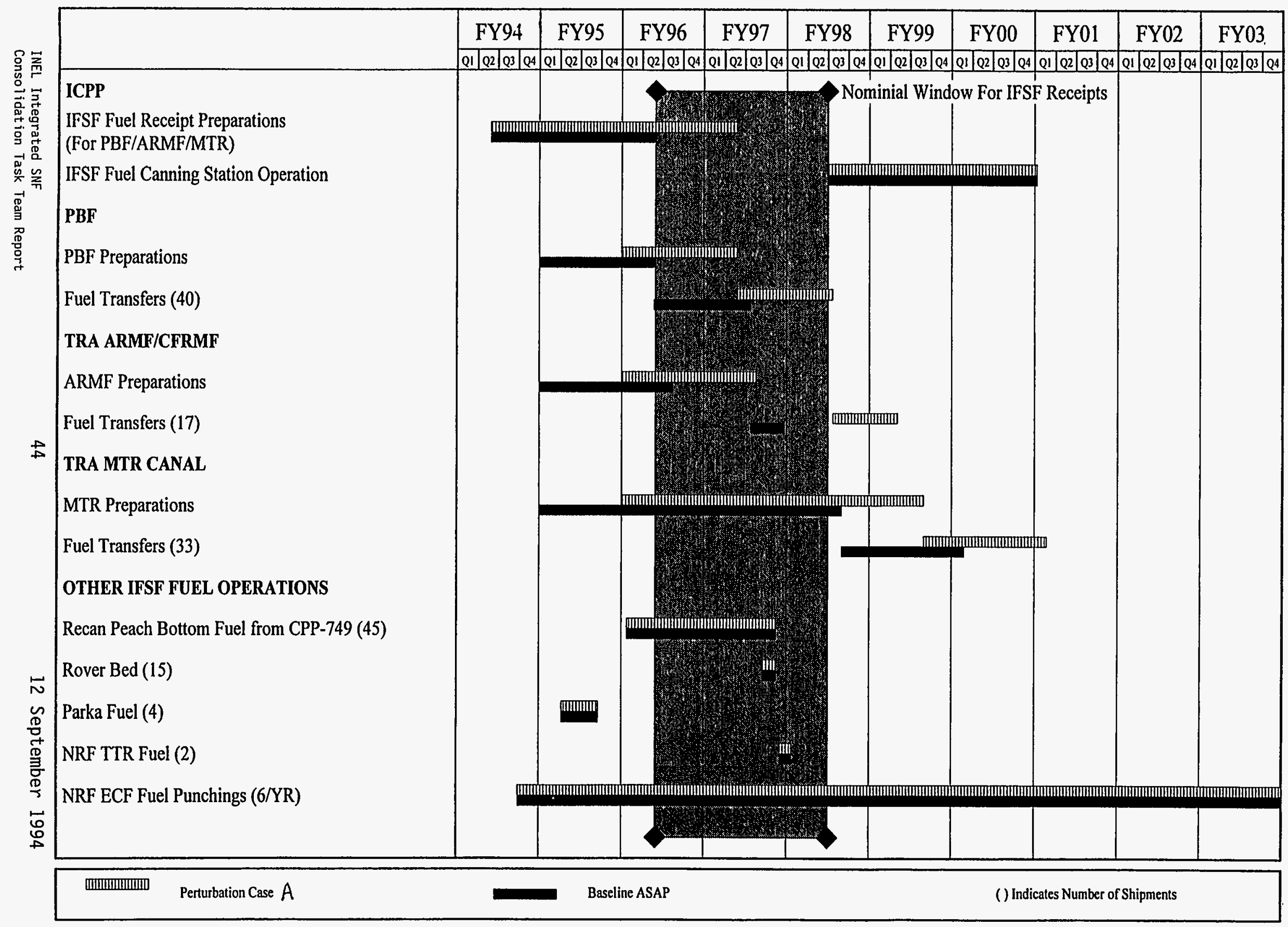

Figure 3.2-1 Case A - Funding Delayed One Year (FY-96) 


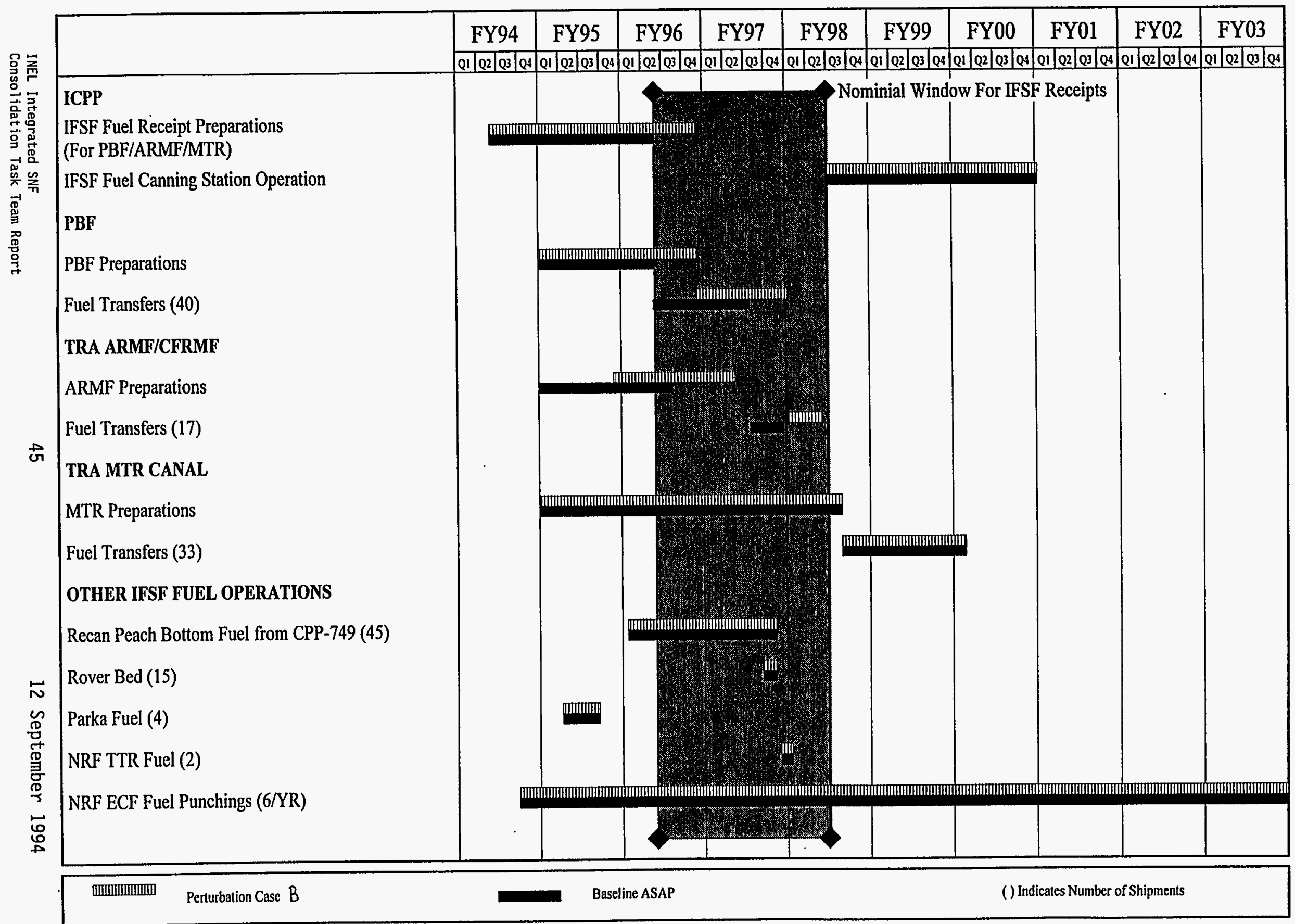

Figure 3.2-2 Case B - Safety Drivers (MTR Canal, Cask Maintenance,IFSF Transfer Cart) 
9/8/1994

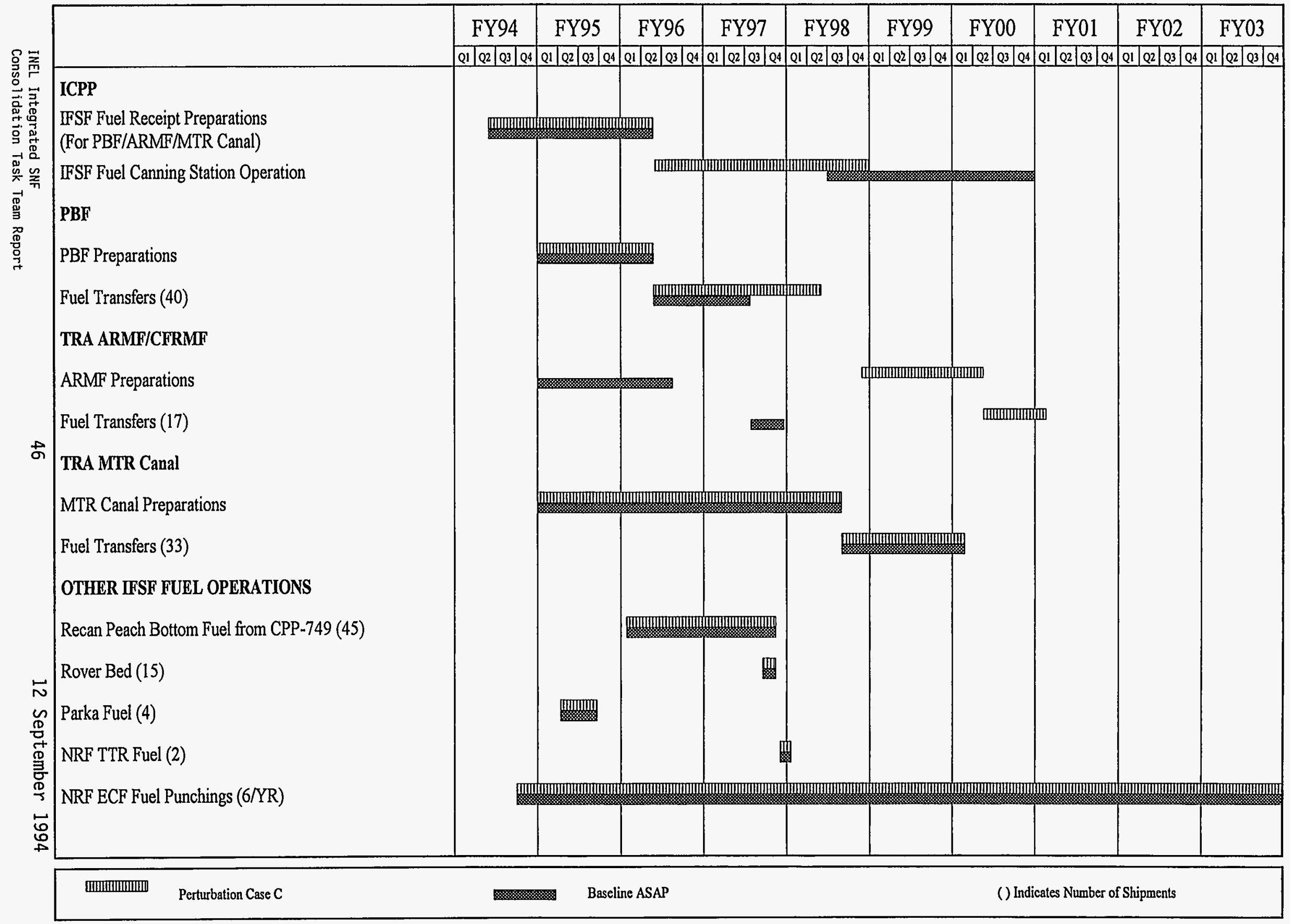

Figure 3.2-3 Case C - Schedule Constraints/Closed Transfer Window 
Table 3.2-1 Additional Costs of Perturbation Cases

\begin{tabular}{|l|c|c|c||}
\hline & CASE A & \multicolumn{1}{|c|}{ CASE B } & CASE C \\
\hline & $\begin{array}{l}\text { Funding Delayed One } \\
\text { Year (MTR Canal, } \\
\text { ARMF/CFRMF, \& PBF) }\end{array}$ & $\begin{array}{l}\text { Safety Driver (MTR } \\
\text { Canal Funded in FY-95; } \\
\text { PBF \& ARMF/CRFMF in } \\
\text { FY-96) }\end{array}$ & $\begin{array}{l}\text { Schedule Constraints, } \\
\text { CTosed Transfer } \\
\text { Window (Paral1e7 SNF } \\
\text { Transfers to IFSF) }\end{array}$ \\
\hline $\begin{array}{l}\text { Increased } \\
\text { Operational Costs }\end{array}$ & $\$ 2,830,583$ & $\$ 1,226,500$ & $\$ 2,844,417$ \\
\hline $\begin{array}{l}\text { Increased SNF } \\
\text { Transfer Costs }\end{array}$ & $\$ 665,000$ & $\$ 0$ & $\$ 2,156,000$ \\
\hline Total Cost & $\$ 3,495,583$ & $\$ 1,226,500$ & $\$ 5,000,417$ \\
\hline
\end{tabular}

\subsubsection{Case B--Safety Drivers}

Case $B$ is very similar to Case $A$. The only difference is some tasks are funded in FY-95 instead of FY-96 (i.e., MTR canal, IFSF transfer cart, TFBP-2 cask preparation, and SNF canister design and construction). Funding for the MTR canal SNF is maintained in FY-95 because the fuel has a greater need to be repackaged due to prior destructive examinations. No additional SNF transfer time is required. Transfer of ARMF/CFRMF and PBF SNF is completed about 6 months later than the base case. Thus, the facility operating costs for Case $B$ are increased over the base case by about $\$ 1.23 \mathrm{M}$. The related costs are shown in Table 3.2-1.

\subsubsection{Case C--Tighter Schedule Constraints/Closed Transfer Window}

Closing the transfer window by interfacing with accelerated, higher priority SNF transfers in the IFSF would increase the overall consolidation time and costs compared to the base case. The operational closure for ARMF/CFRMF, PBF, and MTR canal are delayed 37, 11 , and 10 months, respectively. Thus, consolidation costs and facility operating costs for Case $C$ are increased over the base case and are calculated to be $\$ 5.00 \mathrm{M}$. 
This page left blank intentionally.

INEL Integrated SNF

Consolidation Task Team Report

NH-CS1.WPD/TC/K:/SP\&I 


\subsection{KEY RESOURCE REQUIREMENTS}

\subsection{INEL FACILITY REQUIREMENTS}

Four existing ICPP storage facilities (IFSF, CPP-749, and CPP-666 for SNF, and CPP-651 for SNM) and two new structures are needed for the INEL SNF consolidation program. The new structures include a dry storage facility for TAN TMI SNF and a concrete pad for TAN commercial SNF storage casks. A brief discussion of these SNF and SNM storage facilities follows.

\subsubsection{IFSF}

The IFSF is a remotely-operated dry vault storage facility, built in 1974, for storing graphite fuels (one Peach Bottom core and nine Fort St. Vrain reactor segments). The IFSF consists of a truck bay, a cask transfer cart system, a fuel handling cel1, a fuel storage room, a crane maintenance area, an operating area, and other support areas (see Figure 4.1-1).

The crane maintenance area, fuel handling area, and fuel storage area are serviced by an overhead 15 -ton crane and a remote manipulator. The cask transfer cart is designed to transfer casks weighing up to 160 -tons between the truck bay and the fuel handling cell. The cask handling crane has a $60-$ ton capacity, but the existing rails were designed to support a larger rail cask handling crane. The existing rail system would need to be replaced for future rail receipts. The cart can be adapted via specifically designed inserts for any top loading cask that can be shipped. Two ES\&H vulnerabilities were identified for SNF stored at the IFSF. They include potential utilities and ventilation system malfunction, and the need for a seismic evaluation of the facility. Actions to resolve both vulnerabilities are underway.

Of the 636 (18 inch diameter $\times 132$ inch long) storage positions, 309 are currently used for fuel storage. The remaining 327 positions are available for SNF consolidation. Nineteen positions will be used to consolidate PBF, TRA ARMF/CFRMF, and TRA MTR canal at IFSF. An additional 11 IFSF positions will be required for the remaining consolidation transfers; TAN LOFT SNF (7), NRF Thermal Test Reactor SNF (2), and Rover bed material (2).

Tabie 4.1-1 shows the SNF storage requirements at the IFSF and CPP-749 for INEL SNF consolidation.

SNF consolidation actually requires very 1 ittle space in the IFSF relative to the 327 positions that are available. The remaining 308 positions could be used to store CPP-603 south bas in SNF that must be recanned (52 positions), and the aluminum SNF that is stored in CPP-666 (63 positions), and still have 214 empty positions after the PARKA SNM is transferred to Oak Ridge.

As noted very early in this plan, Fort St. Vrain (FSV) shipments to the IFSF were not included. The last column in Table 4.1-1 identifies the needed FSV storage capacity (366 positions), which is greater than the available 329 positions. 
Table 4.1-1 Dry SNF Storage Requirements for INEL Consolidation

\begin{tabular}{|c|c|c|c|c|c|c|c|c|}
\hline \multicolumn{9}{|c|}{ Dru Storage Positions in IFSF and CPP-749 } \\
\hline $\begin{array}{l}\text { SNF Storage } \\
\text { Location }\end{array}$ & $\begin{array}{l}\text { Capacity (Storage } \\
\text { Positions) }\end{array}$ & \begin{tabular}{|c|} 
Capacity \\
Required For \\
Current \\
Operations \\
\end{tabular} & $\begin{array}{l}\text { Capacity } \\
\text { Required for } \\
\text { Operations } \\
\text { After CPP-749 } \\
\text { Vault Transfers } \\
\end{array}$ & $\begin{array}{c}\text { Capacity } \\
\text { Available for } \\
\text { Future } \\
\text { Operations } \\
\end{array}$ & $\begin{array}{c}\text { Capacity } \\
\text { Required For } \\
\text { INEL SNF } \\
\text { Consolidation } \\
\end{array}$ & $\begin{array}{c}\text { Capacity } \\
\text { Available After } \\
\text { INEL SNF } \\
\text { Consolidation } \\
\end{array}$ & \begin{tabular}{|c|} 
Capacity After \\
Consolidation \& IFSF \\
Transfers To CPP-749 \\
\& Oak Ridge \\
\end{tabular} & $\begin{array}{c}\text { Capacity } \\
\text { Required to } \\
\text { Receive FSV } \\
\text { SNF at PSC* }\end{array}$ \\
\hline IFSF & 636 & 309 & 309 & 327 & 19 & 308 & 329 & 366 \\
\hline \multirow[t]{2}{*}{ CPP.749 } & 62 (1st Generation) & 59 & 0 & 요 & 0 & 0 & 0 & $\underline{0}$ \\
\hline & 157 (2nd Generation) & 70 & 129 & 28 & 11 & 17 & 15 & $\underline{0}$ \\
\hline \multicolumn{9}{|c|}{$\begin{array}{l}\text { INEL SNF Consolidation plans for ICPP dry storage facilities will require about } 30 \text { dry storage positions (PBF, ARMF/CFRMF and MTR Canal - } 19 \\
\text { IFSF positions; LOFT/TAN - } 7 \text { IFSF positions; TTR - } 2 \text { IFSF positions; Rover Bed - } 2 \text { IFSF Positions. Future transfer of the ARMF/CFRMF inventory trom } \\
\text { IFSF to CPP-749 will tree two positions in IFSF and require two more positions in CPP-749. PARKA Shipments from IFSF to Oak Ridge will free an } \\
\text { additional } 19 \text { positions in IFSF. }\end{array}$} \\
\hline
\end{tabular}




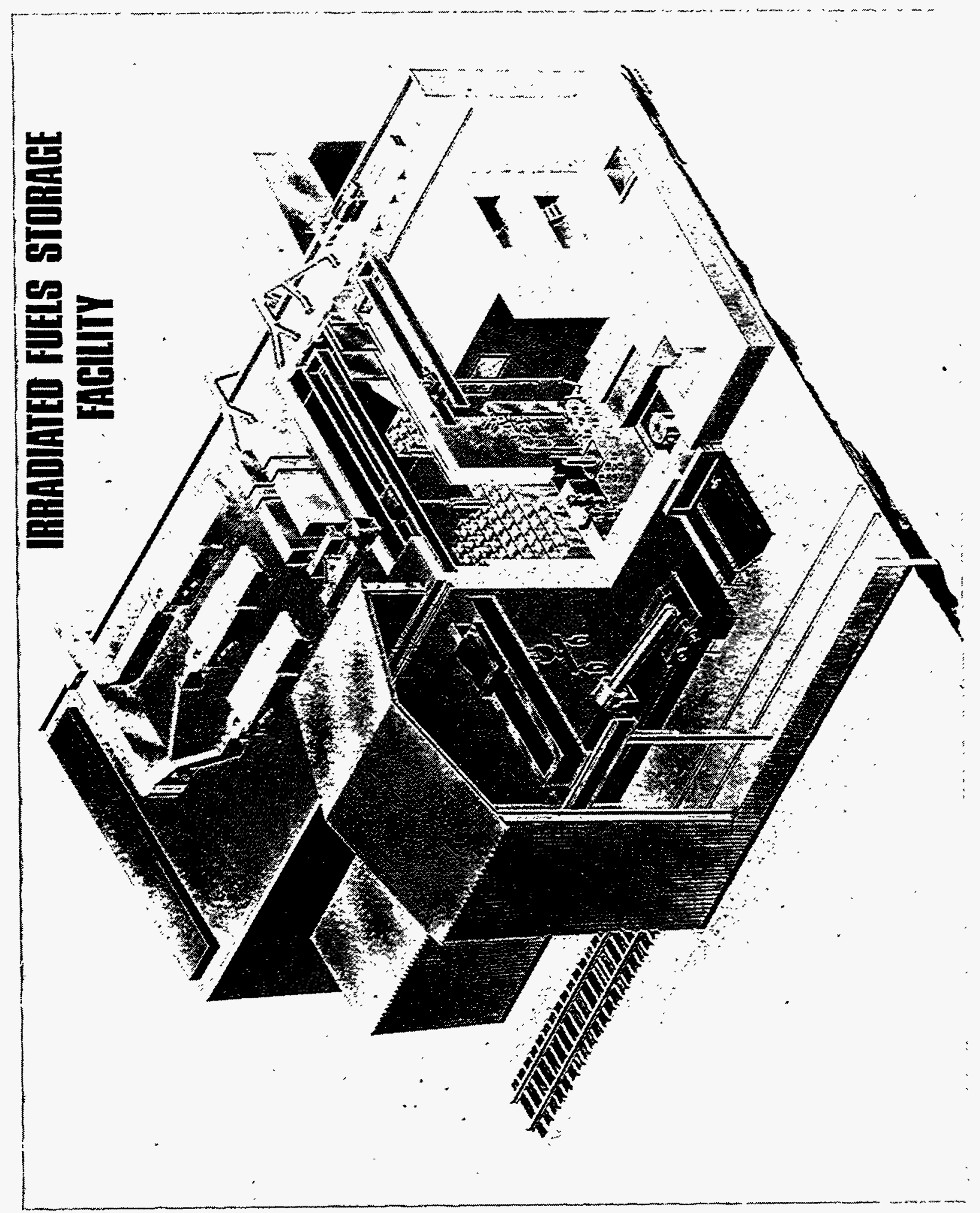

Figure 4.1-1 Cutaway of IFSF

INEL Integrated SNF 


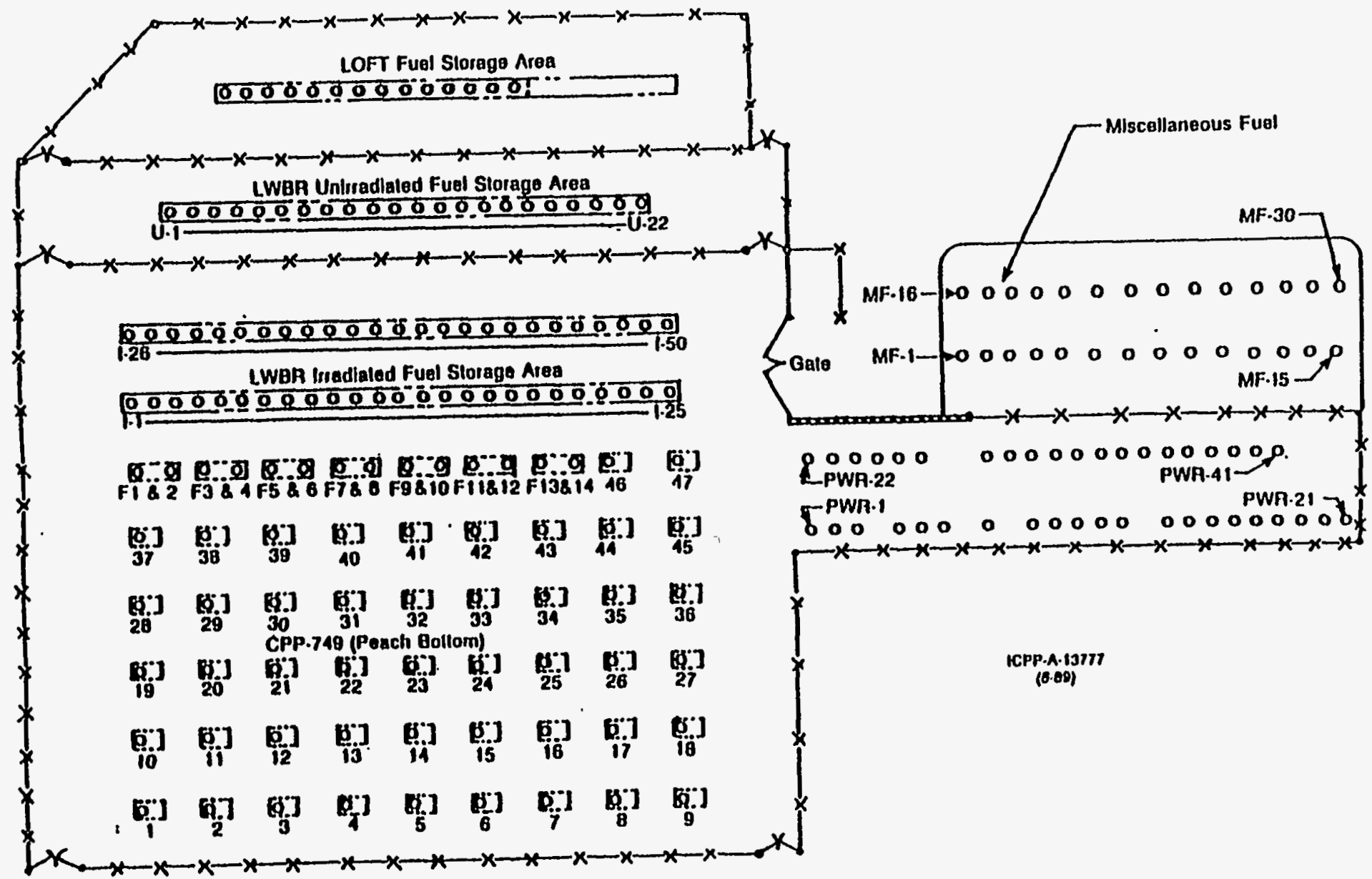

Figure 4.1-2 Layout of CPP-749 


\subsubsection{CPP -749}

CPP-749 consists of 218 underground dry vaults (we17s) that were built in seven separate projects between 1971 and 1987. Figure 4.1-2 shows a layout of CPP-749. A71 vaults except the unirradiated Light-Water Breeder Reactor wells are approximately 30 inches in diameter $\times 240$ inches deep. They are loaded by placing a transfer cask centering device over the well, locating a transfer cask over the centering device, removing the cask bottom 1id and finally lowering the spent fuel package with a rod that protrudes through a small hole in the cask top lid.

The Peach Bottom and Fermi dry vaults were built using carbon steel casings and caps, and grout-bottom plugs. Over the years, moisture has seeped through the grout via evaporation resulting from the SNF decay heat and consequent condensation on the metal cap. This has caused significant corrosion on the Peach Bottom fuel aluminum canisters. Plans are to recan the Peach Bottom fuel in the IFSF handling cell, as needed, and move the fuel to the second generation existing empty dry vaults. The Fermi fuel would also be moved, although no corrosion to the stainless steel storage canisters is suspected.

The Peach Bottom and Fermi dry vaults may be renovated; however, this study has assumed that they are not renovated. The change in storage capacity following the SNF transfers to the second generation vaults is shown in Table 4.1-1. Renovation of the first generation vaults would require new stainless steel liners, instrumentation to monitor for vault leaks, and sampling/purging capability for the vault (1iquid and gas). Generally speaking, renovation is not likely because underground vaults have not been selected as the best future storage option.

The last five dry vault wells (second generation design) have improved features that include an a 17 -metal storage well encased in grout. The design also provided capabilities for purging and sampling the dry vault interior. These dry vaults are 12 and 18 inches in diameter and about 273 inches deep. A 30-ton gantry crane is used to move the transfer casks from the transfer truck to the dry vaults.

\subsubsection{CPP-666 Fue1 Storage Area}

CPP-666 Fuel Storage Area is an underwater fuel storage facility comprised of six storage pools, two unloading pools, two isolation pools, a fuel transfer canal, and an enclosed fuel cutting pool. The facility is designed to withstand a Design Basis Earthquake. The pools are stainless-steel lined with a leak detection system. The facility uses an extensive water chemistry control system, and has a heating, air conditioning and ventilation (HVAC)/confinement system.

CPP-666 is the most modern spent fuel wet storage facility in the DOE complex. Storage of spent fuel began there in 1984. Spent fuel from NRF, ATR, the High Flux Beam Reactor, Experimental Breeder Reactor-II, and the Fermi Blanket are in storage. Approximately 5.6 MTHM of non-Naval fuel is stored in freestanding SNF storage racks, which provide criticality-safe spacing. Projects to expand storage capacity and provide for inspection/characterization will be required if SNF is not removed from the basins. See Figure 1.4-2. 


\subsubsection{CPP-65I Unirradiated Fuel Storage Facility}

The CPP-651 Unirradiated Fuel Storage Facility consists of a concrete building divided into an inner concrete structure with seven storage rooms, an annulus between the storage rooms and the outer concrete shed, and a receiving area. Six of the storage rooms are approximately $10 \mathrm{ft}$ long $x 12 \mathrm{ft}$ wide. The seventh storage room is $19 \mathrm{ft}$ long $\times 25 \mathrm{ft}$ wide. The storage rooms can be used for shipping drum storage, or can be fitted with engineered racks that store fuel in individual canisters or bundles. Currently, two of the rooms are fitted with engineered racks. The annulus has been recently fitted with 100 storage caissons in the floor. The cajssons $(8$ inches in diameter $\times 96$ inches long) have seven-position racks that are lowered into the caissons with an overhead hoist. Originally designed for storage of $\mathrm{UO}_{3}$ product from the ICPP processing operations, much of this storage is now available for other missions. Nuclear material with low surface radiation levels can be stored in these racks because they are stored in concrete shielded caissons.

CPP-651 is fitted with appropriate security and criticality alarm systems for unshielded facilities. Adequate room is available for some consolidation of unirradiated material from the DOE complex. Efforts are underway to deve 10 p markets for the unirradiated material where it can be recycled for reuse or for incorporation into the commercial nuclear fuel supply system.

Figure $4.1-3$ is a layout of CPP-651.

\subsubsection{New Facilities for TAN SNF}

One potential method of TMI canister storage at ICPP is in a single, above-ground, vault structure near CPP-749. Figure 4.1-4 shows the structure as present7y envisioned. Canisters would be stored in shielded vertical ports that have both shielded covers and confinement capabilities. The structure would have a gantry crane with an enclosing cover. The cask would be unloaded in a receiving area then transferred to a single port. The cask and skid would be removed from the trailer and pinned to the floor of the receiving area. Cask opening and unloading would use equipment that GPU Nuclear Corporation used to load the casks at TMI. The canisters would be lifted into the shielded transfer device and the gantry crane moved to the storage location. The transfer device would be lowered to the receiving port and the canister lowered to the storage position. A shield plug and lid would then be replaced to seal the canister in location. That operation would be repeated until the cask is unloaded.

A concrete pad will be built near CPP-749 to store the TAN commercial SNF. The pad will consist of reinforced concrete $2 \mathrm{ft}$ thick with design compressive strength of $27,580 \mathrm{kPa}(4000 \mathrm{psi})$ at 28 days. The storage pad will be at the same level as the road bed to minimize the height that casks are raised during transfers. It will be sloped slightly $(3 \%)$ to enhance water runoff. A movable fence may be installed around the casks to designate an administrative boundary and to post warning signs. All construction activities will be in compliance with the Building Officials and Code Administration International Basic Building Code and the American Concrete Institute Building Code Requirements for Reinforced Concrete (ACI 318-13 and Commentary). 

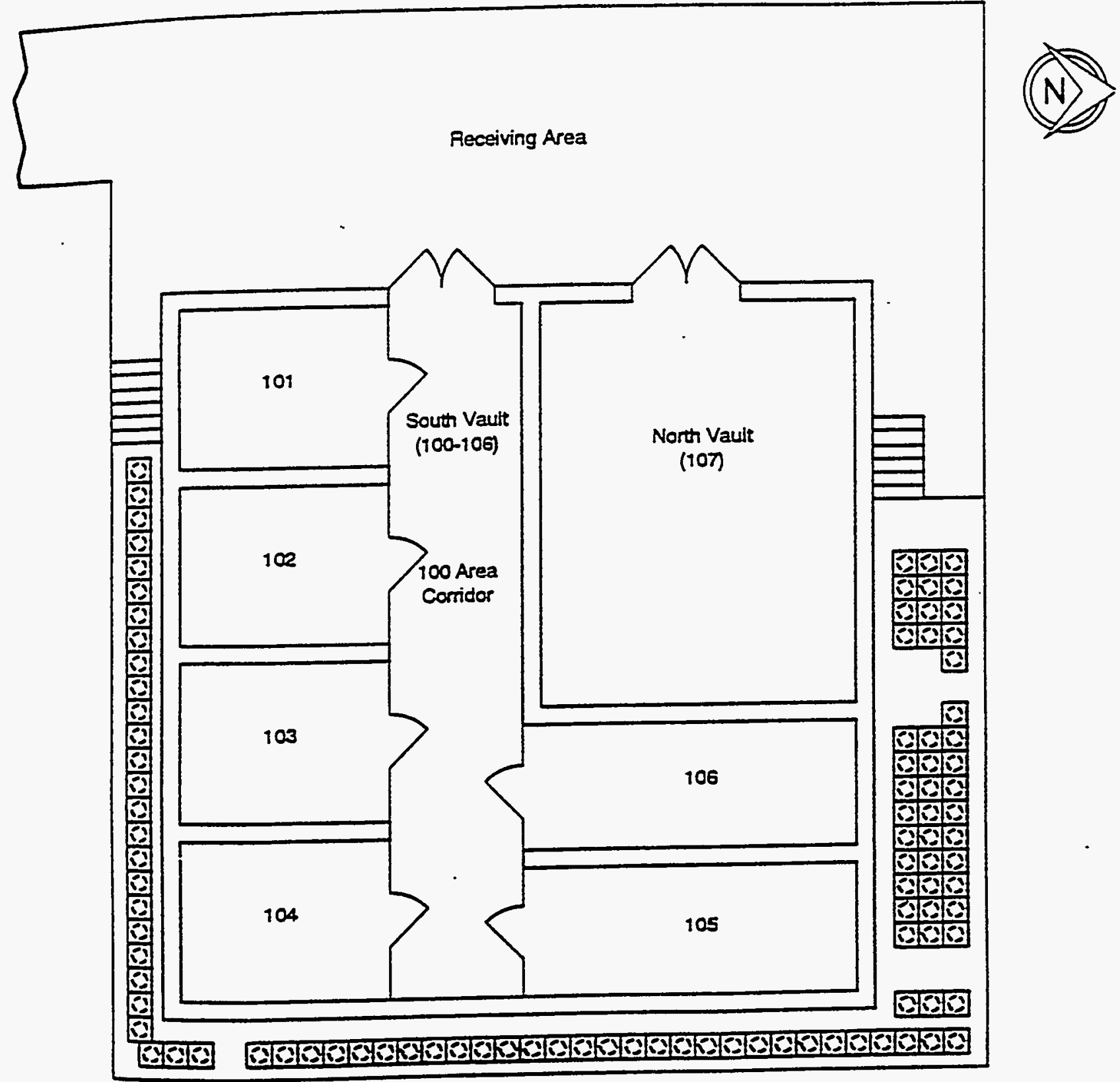

Figure 4.1-3 Layout of CPP-651 


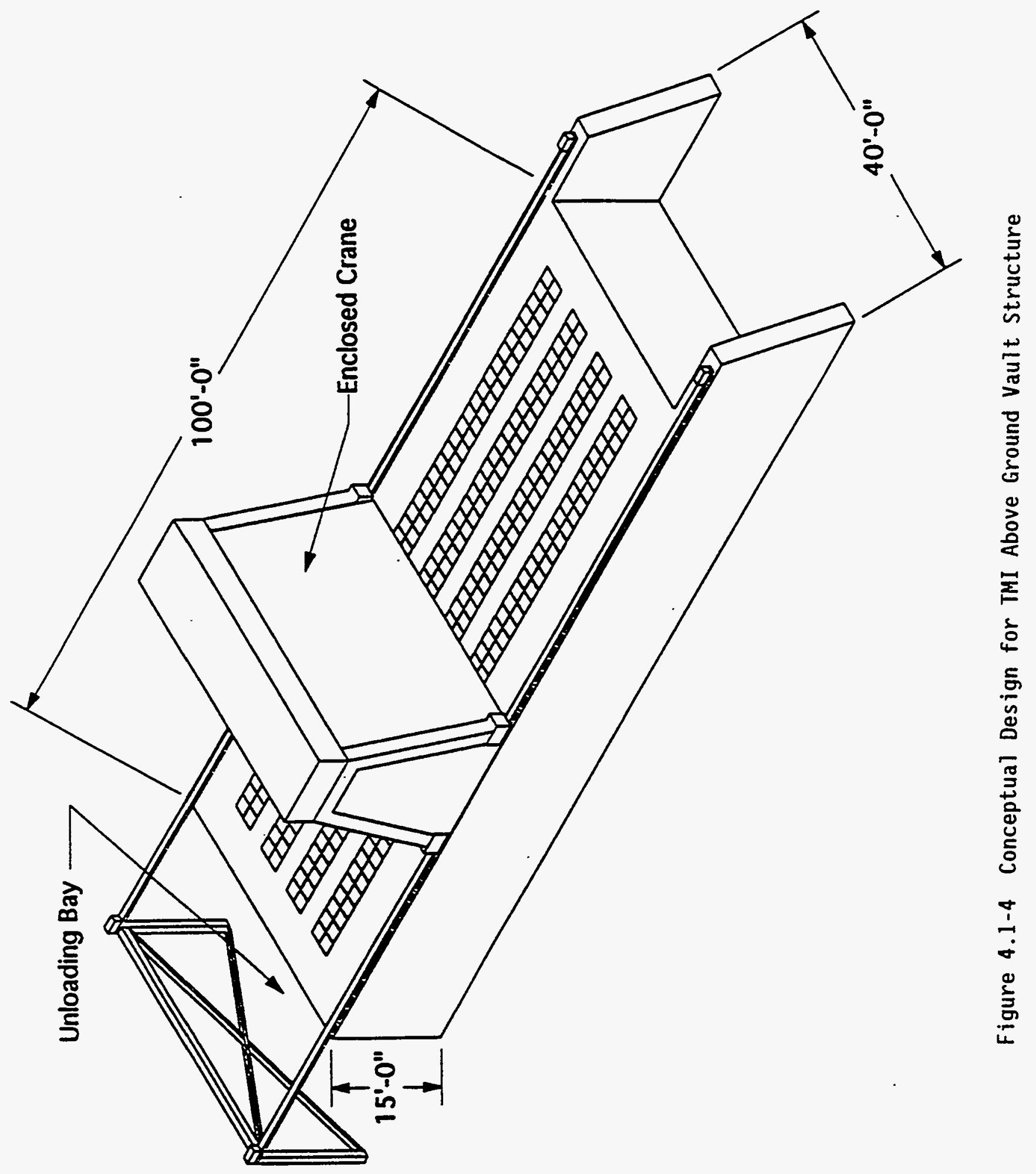

INEL Integrated SNF

Consolidation Task Team Report 


\subsection{INEL ROADS AND EQUIPMENT REQUIREMENTS}

\subsubsection{INEL Roads and Bridges}

The road system at the INEL is adequate for transport of SNF. Most SNF transfers are within the INEL controlled boundaries. Lincoln Boulevard is the main north-south road on the INEL. The road was rebuilt in 1989-1990 and is in excellent condition for transport of casks in most weather conditions. The roads that connect between Lincoln Boulevard and NRF, TRA, and PBF are also expected to be in satisfactory condition. However, the routes taken need to be inspected before initiation of cask shipments. Two Lincoln Boulevard bridges, one between ICPP and TRA, the other north of the NRF junction, need to be analyzed for the expected loaded cask-trailer weight.

\subsubsection{Description of Casks}

\subsubsection{TRA Hot Cells Carrier}

The Hot Cell Carrier Number-2 cask (also known as WE-2) cask is used to transport SNF on the INEL. Figure 4.2-1 shows the major features of the cask. This cask has a carbon steel outer liner, a stainless steel inner 1iner, and lead shielding between the two liners. The cask is about 28 inches in outer diameter by 92 inches long. The cask has a 6 inch diameter by 62 inch 7 ong cavity. Two trunions are provided for lifting. The empty cask weighs about 21,600 pounds.

The cask has a rotating plug with a full cask inner diameter hole for closure at one end. A locking pin provides additional security during transport. The cask has a shovel that loads through the opposite end. A removable extension attaches to the shovel for loading and unloading.

A pallet is provided for truck transport, see Figure $4.2-1$. The cask is tied to the truck with four $3 / 8$-inch chains. The truck is 1 imited to $35 \mathrm{mph}$ during transport. An optional wheeled dolly is available for use inside an INEL facility.

\subsubsection{Thermal Fuel Behavior Program Cask Number 2 (TFBP-2)}

The TFBP-2 was designed as a versatile package for transporting experimental test assemblies and irradiated experiments between PBF and various TRA

facilities. Figure 4.2-2 shows major cask system components. The TFBP-2 cask has a lower and an upper cask assembly. The lower cask has a 304 stainless steel inner and outer shell with lead fill between the shells for radiation shielding. The lower end of this cask section has a mechanically operated shield door. Bolted to the upper end of the lower cask is either the upper cask or a shielded closure head. The lower cask is 115 inches long. The outside diameter of the main body of the lower cask is 23 inches. Flanges, lifting attachments, and the shield door increase the radial clearance requirements considerably. The cavity size of the lower cask is 92 inches long by 10.20 inches in diameter.

The upper cask also has a 304 stainless steel inner and outer shel1 with lead fi11. However, the shielding thickness is less than the thickness of the 

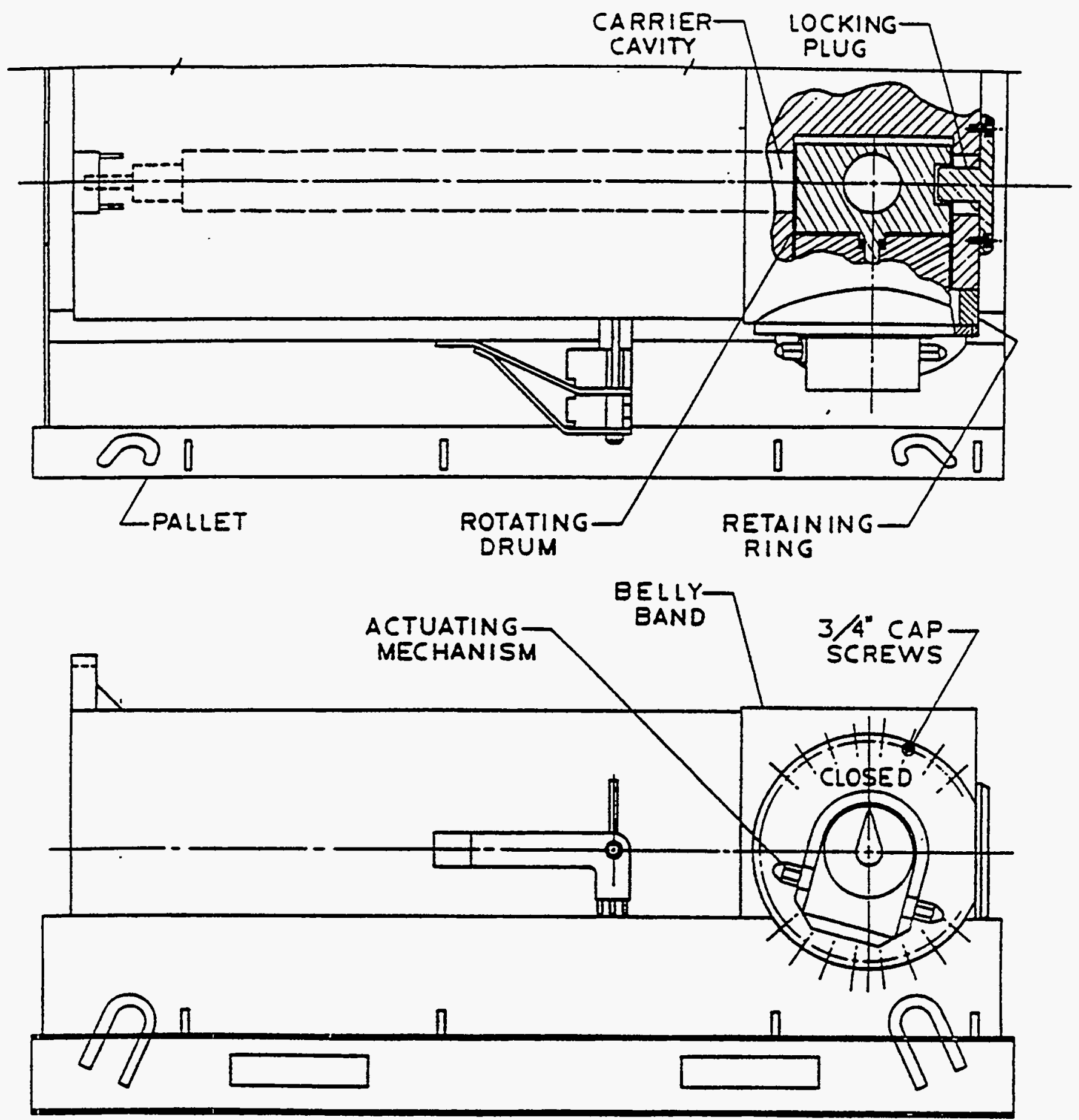

TRANSPORT ARRANGEMENT

Figure 4.2-1 TRA Hot Cells Carrier 


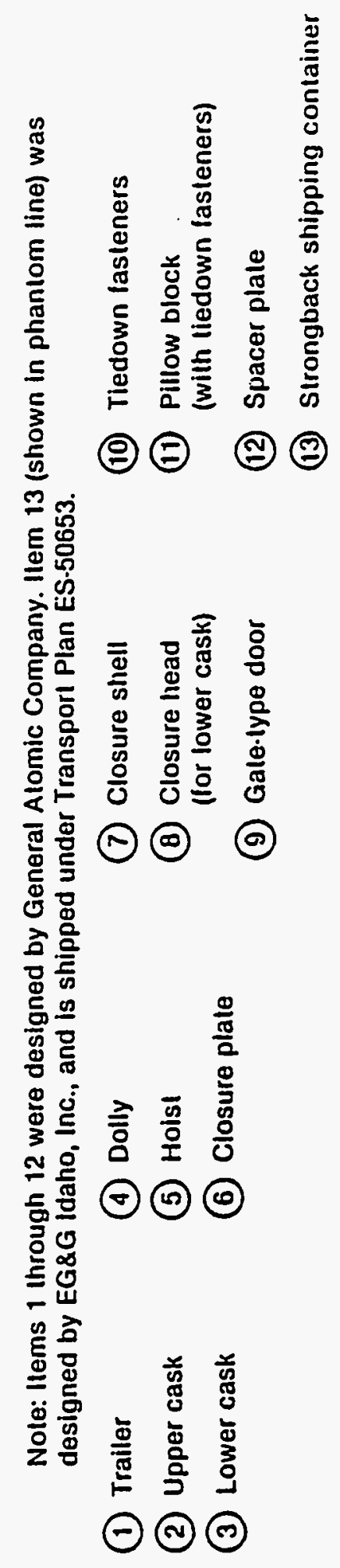

INEL Integrated SNF

Consolidation Task Team Report

NH-CS1.WPD/TC/K:/SP\&I .

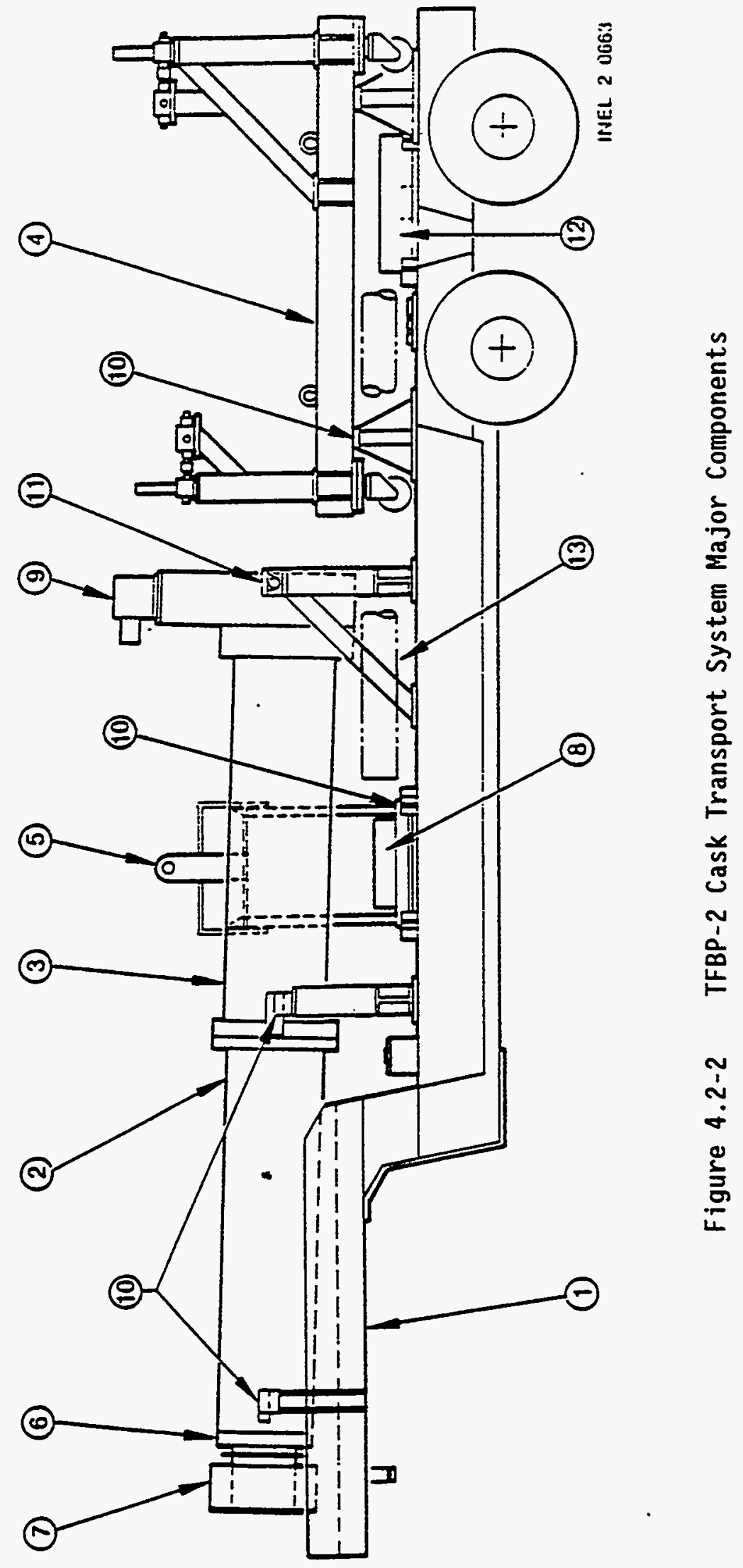

59 
lower cask. A closure shell and plate attach to the upper end of the upper cask. The upper cask section will not be used for transport of PBF SNF.

A dolly allows the cask to be handled in a horizontal orientation. This will be useful for loading the cask in the TRA Hot Cells. An integral electrical hoist is used to load and unload the cask. A trailer is provided for transport of the TFBP-2 cask between INEL facilities. The TFBP-2 cask has an existing DOE-ID-approved transport plan. However, the transport plan must be reviewed and approved to address new safe transport requirements, and the additional TRA ARMF/CFRMF and TRA MTR canal SNF transfers.

\subsubsection{Peach Bottom Cask Number 2}

Peach Bottom cask CA-SF-005 (formerly PB-2) is used at ICPP and could transport SNF at other sites on the INEL.

The cask is a cylindrical vessel with lids at both ends. The main cylinder has a stainless steel inner she11, a carbon steel outer she11, and lead shielding between the two shells. The original lids for the cask are lead filled stainless steel. Two new stainless steel lids have been fabricated to replace the original 1ids. External, cylindrical, energy absorbers are attached to both types of $1 \mathrm{ids}$. The diameter of the cask is about 42.62 inches. The length of the cask with original 1 ids is 173.12 inches. For a cask with new lids, the length increases to 176.06 inches. With overpacks, the lengths increase to 191.12 and 194.06 inches, respectively. The fully loaded cask weighs 68,360 pounds in the original configuration and 68,770 pounds for a cask with new lids. Two trunions are provided at each end of the cask for tie-down during shipping and for lifting the cask. The cask interior cavity is a 26 inches diameter by 159 inches long. Figure 4.2-3 shows the casks in original configuration.

The trailer used to transport the Peach Bottom cask at ICPP is based upon a standard flat bed design. The trailer has supports with cover blocks that connect to the cask trunions. The cask is transported in a horizontal position. A painted carbon steel cover provides weather protection for the cask assembly.

\subsubsection{NuPac 125-B}

The Nuclear Packaging (NuPac) 125-B cask was used to transport TMI core debris to the INEL. This cask is certified by the Nuclear Regulatory Commission (NRC). The certification is expected to be maintained. The cask was designed by Nuclear Packaging, Inc. in the mid-1980s for rail transport of the debris canisters followed by truck transport to the TAN-607 Hot Shop. The cask is a skid-mounted, double-contained cask with end-mounted Overpacks. Figure 4.2-4 shows the assembled cask and Figure $4.2-5$ is an exploded view that shows the major components of the NuPac 125-B cask. The cask is about 66 inches in diameter by 208 inches long. Attached to each end of the cask is a 120 inch diameter by 75 inch long overpack. The overpacks provide energy absorption in case of an accident. The cask is attached to a rail car or truck transporter by a skid. A fully loaded cask weighs about 79 tons. Each overpack weighs an additional 5.9 tons and the transport skid weighs about 11 tons. The cask will transport seven TMI canisters. 


\section{CAPACITY.}

(4) 55 GALLON DRUMS

C R ( 1 ) 45 CU FT CONTAINER

\section{WEIGHT}

GROSS WEIGHT 68,360 POUNDS (EMPTY)

CASK BODY WEIGHT: 53,110 POUNDS

LIDS: 1,995 POUNDS EACH

IMPACT LIMITERS: 630 POUNDS EACH

MODE OF TRANSPORTATTON

TRUCK/TRAILER
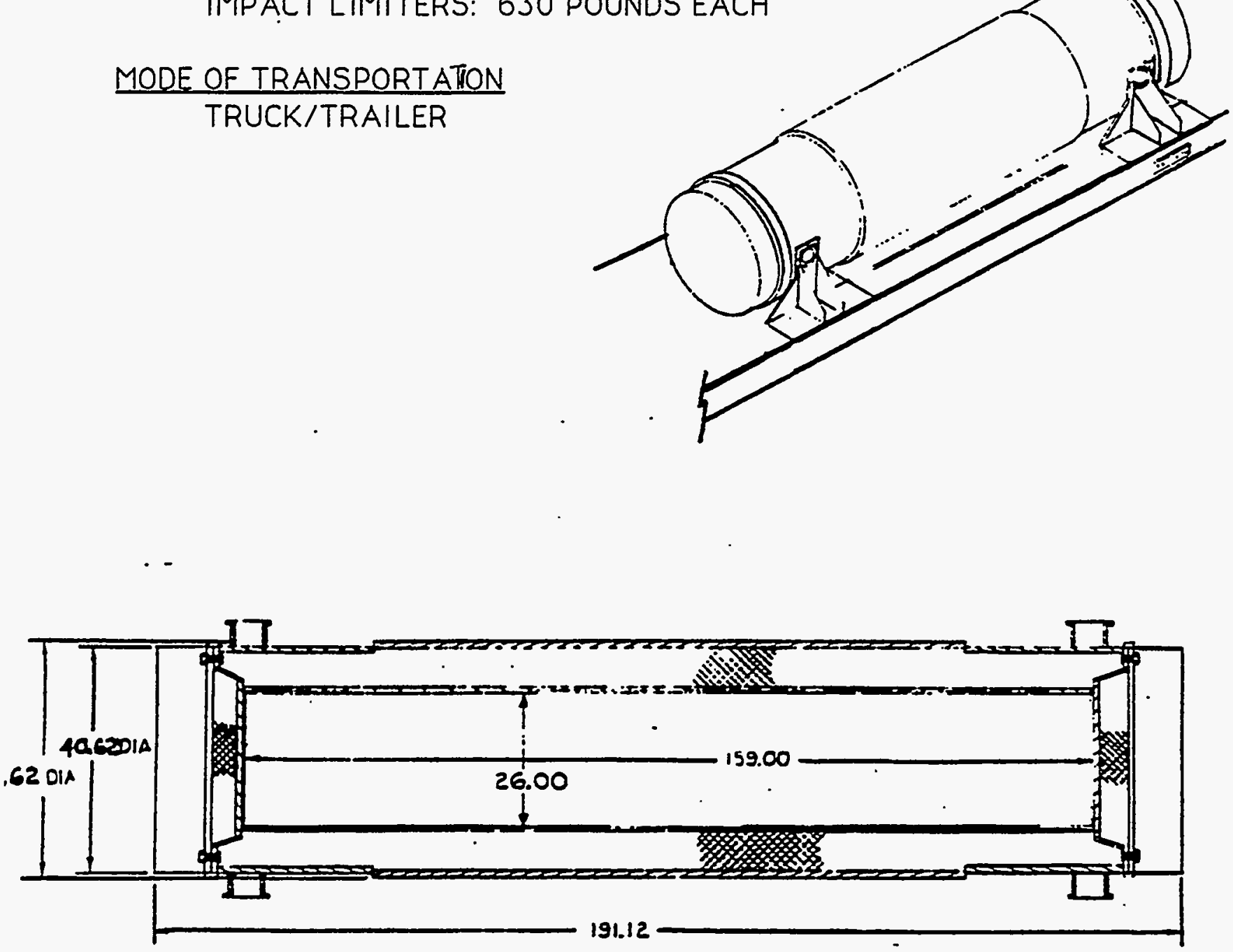

Figure 4.2-3 Peach Bottom Cask 


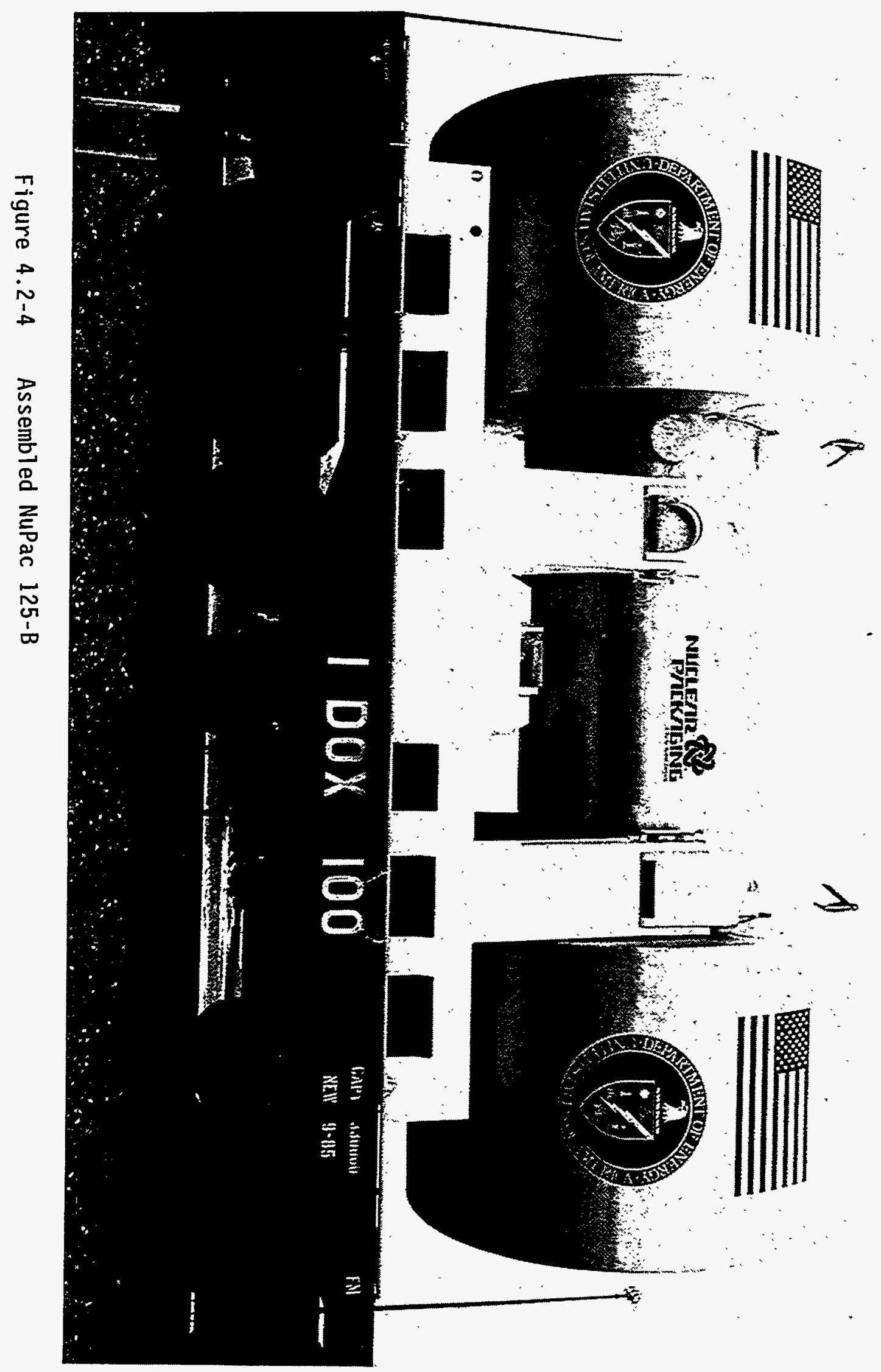




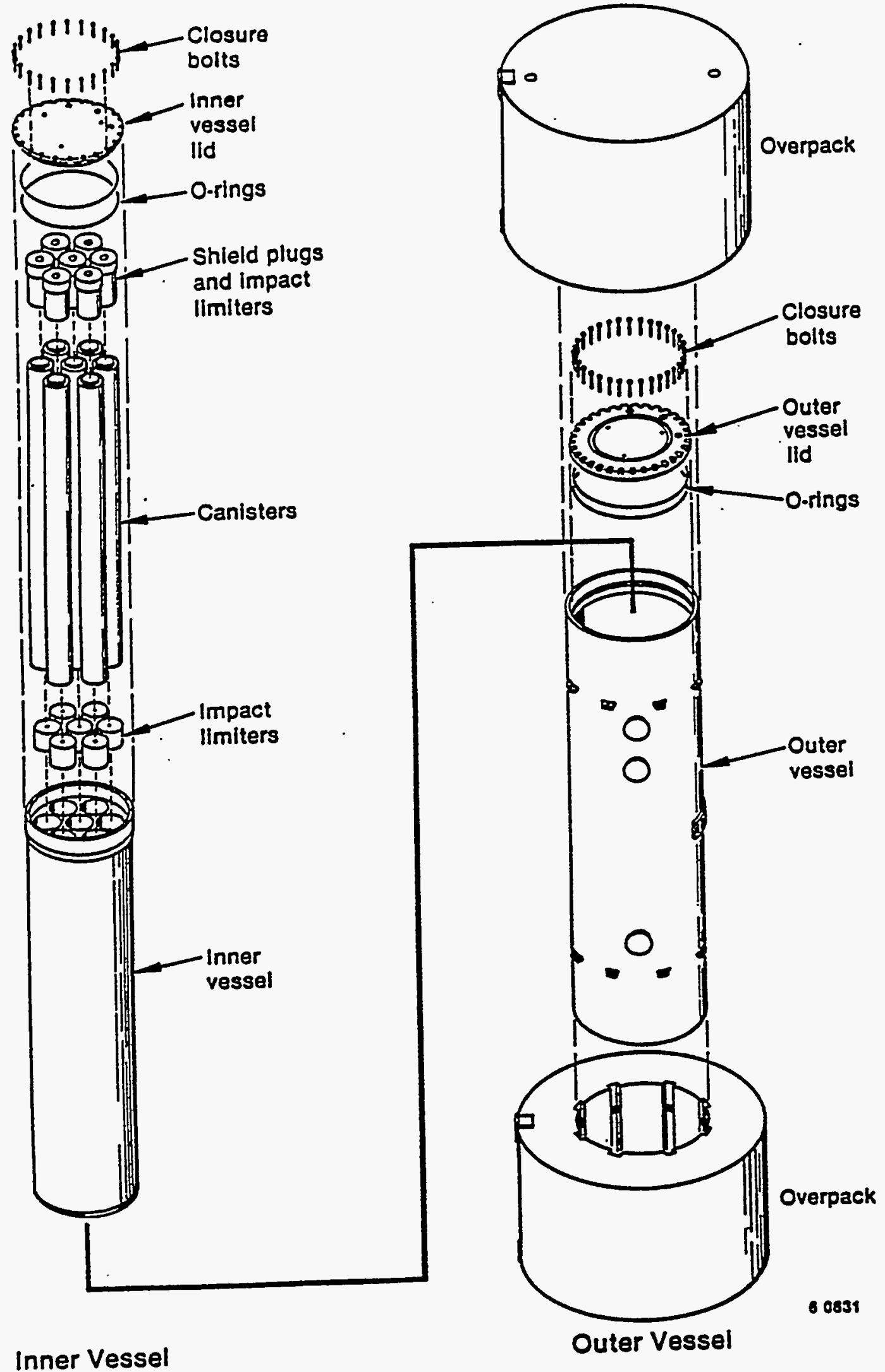

Figure 4.2-5 Major Components of the NuPac 125-B 
The trailer originally used to transport the TMI core debris to TAN has inadequate capacity to transport the cask with overpacks from TAN to ICPP. The added weight of the overpacks will cause the package to exceed the rating of the trailer. In addition, the forward overpack cannot be removed from the cask if the existing trailer were used. A new transporter that is designed to transport the NUPaC $125-\mathrm{B}$ and the three TAN dry commercial SNF casks is required.

\subsubsection{Dry Commercial Spent Nuclear Fuel Casks}

\section{CASTOR $V / 21$}

The Castor V/21 cask was designed and fabricated by General Nuclear Systems, Inc. for dry storage of commercial SNF. The cask is about 95 inches in diameter by 189 inches tall. The cask will store 21 commercial Pressurized Water Reactor fuel assemblies. Fully loaded, Castor V/21 will weigh about 90 (U.S.) tons. The cask is a thick-walled, nodular cast-iron container. The SNF is stored in an inert gas atmosphere. External fins are provided for heat removal. Two pairs of trunions are provided for lifting, tie-down, and rotation. The cask stores SNF in a vertical orientation. However, the cask has been tested in a horizontal orientation with no adverse consequences.

MC-10

The MC-10 was designed and fabricated by Westinghouse for the dry storage of commercial SNF. The cask is about 105 inches in diameter by 189 inches tall. Either 24 commercial fuel assemblies or canisters of consolidated SNF rods can be stored in the cask. Fully loaded, MC-10 will weigh about 112 tons. The cask is a forged steel container with an integrally welded forged steel bottom. Twenty-four nickel-plated fins are attached to the outside of the vessel for heat removal. Three bolted 1 ids close the cask. The final closure is a fourth lid of stainless steel that is welded in place. Four removable trunions facilitate cask handling. The trunions are replaced with neutron shield plugs for storage. The cask stores SNF in a vertical orientation. However, the cask has been tested in a horizontal orientation with no adverse consequences.

\section{TN-24P}

The TN-24P cask was designed and fabricated by Transnuclear for the dry storage of commercial SNF. The cask is about 90 inches in diameter by 200 inches tall. Up to 24 commercial fuel assemblies or canisters of consolidated SNF rods can be stored in the cask. A ful1y loaded TN-24P wi17 weigh about 97 tons. The cask is a forged steel container with an integrally welded forged steel bottom and a bolted forged steel 1id. The SNF is stored in an inert gas atmosphere. Heat is removed from the cask through the external surface and cooling fins are not required. The cask has three pairs of trunions bolted to the cask for lifting, tie-down, and rotation. A neutron shield drum is installed on the cask lid during storage. A protective cover is installed on the cask for weather protection of the upper section. The cask stores SNF in a vertical orientation. However, the cask has been tested in a horizontal orientation with no adverse consequences. 


\subsubsection{TN-8L Spent Fuel Shipping Cask}

The TN-8L spent fuel shipping cask is a truck mounted cask by Transnuclear, Inc. The cask will ship three commercial Pressurized Water Reactor or Boiling Water Reactor SNF assemblies. The cask is about 192 inches long. Figure 4.2-6 shows the cross-section of the cask. The inner-most layer is stainless steel surrounded by concentric layers of boron carbide/copper plates, lead gamma radiation shielding, cement, and steel. The outer layer is a borated resin neutron shield. The TN-8L has 104 rows of nickel-plated copper heat transfer fins. The three cavities for SNF fuel assemblies are each about 9 inches square by 168 inches long. A filled TN-8L weighs less than 39.7 tons. Trunions are provided for both tie-down and lifting. The cask is supplied with a dedicated trailer for transport.

\subsection{PERSONNEL AND TRAINING REQUIREMENTS}

The increase in IFSF SNF handling and receipts will require additional operating personnel. The manpower histograms for operators, supervisors, engineering support, and health physicists are shown in Figures 4.3-1 through 4.3-4, respectively. These figures depict the annual manpower requirements for supporting a17 of the ICPP SNF tasks during this consolidation program. The resources required for SNF consolidation are identified by the black boxes on the very top of each column. The horizontal line in each figure identifies the available manpower.

Those years that exceed this level represent shortfalls. These shortfalls can be eliminated by adding about 10 new fuel handling operations personnel, 2 operations supervisors, 2 facility support engineers, and 2 health physicists. Operations personnel need to be hired by 1995 in order to complete their training programs for the ICPP facilities. These personnel will be added to existing crews to minimize the impact of assimilating new employees.

These additional personnel are required for SNF consolidation activities only. New SNF tasks resulting from the Programmatic SNF and INEL ER\&WM EIS Record of Decision will require additional personnel and adequate time for their training programs. The manpower requirements for the perturbation cases $A, B$, and $C$ were not evaluated.

\subsection{DOCUMENTATION REQUIREMENTS}

\subsubsection{Transportation}

Al1 shipments of radioactive materials on the INEL are required to be documented according to established procedures. A Radioactive Material Shipment form and DOE/NRC-741 for SNM transfer are the minimum documentation required. Other information may also be required depending upon the characteristics of the SNF and cask configuration.

Many SNF transfers will be made within controlled boundaries of the INEL and DOT/NRC licensed casks are not required. However, safety equivalent to that provided by DOT regulations is required for on-site transfers. Some casks 


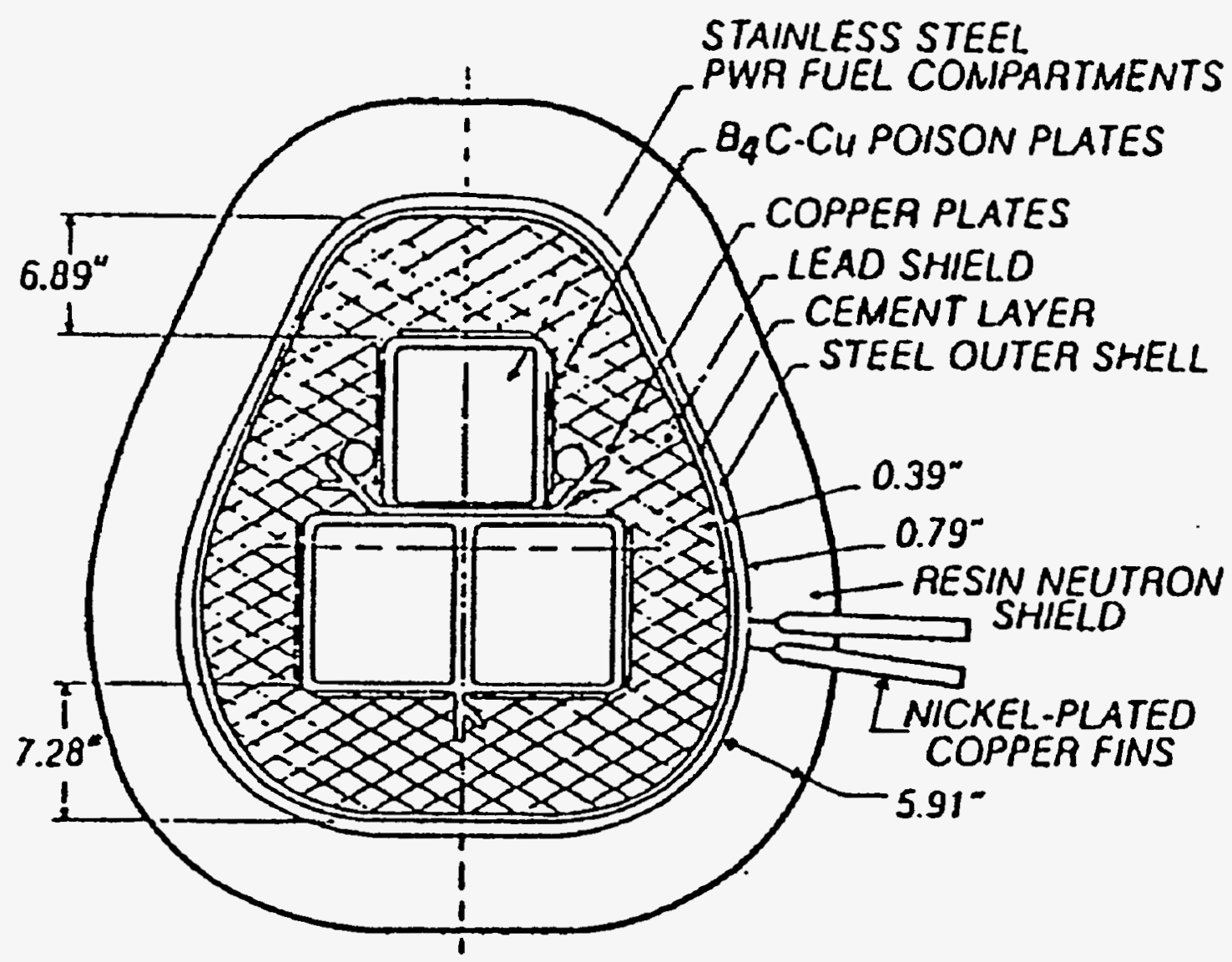

Figure 4.2-6 Cross-Section of the TN-8L Shipping Cask 


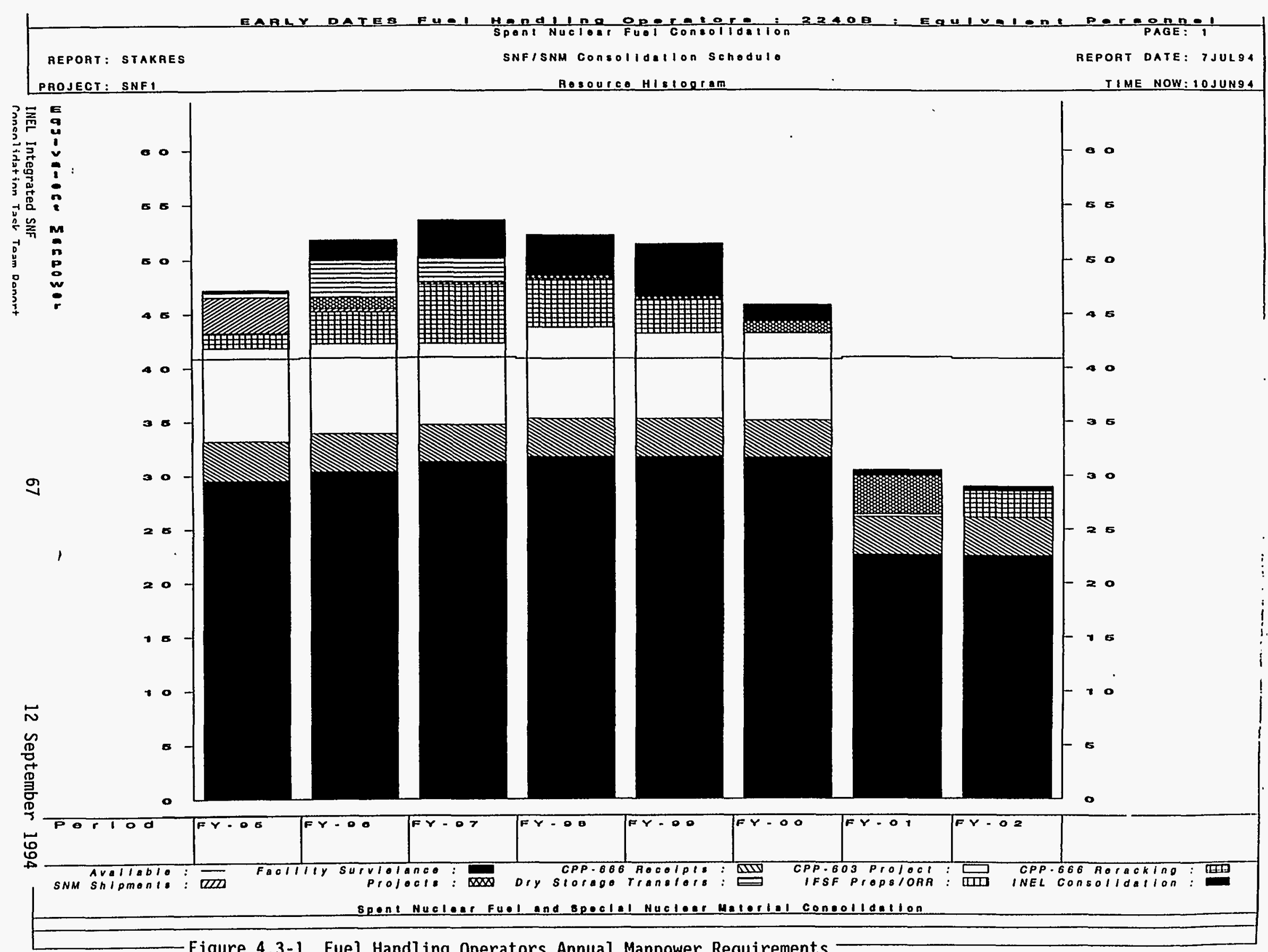

-Figure 4.3-1 Fuel Handling Operators Annual Manpower Requirements 


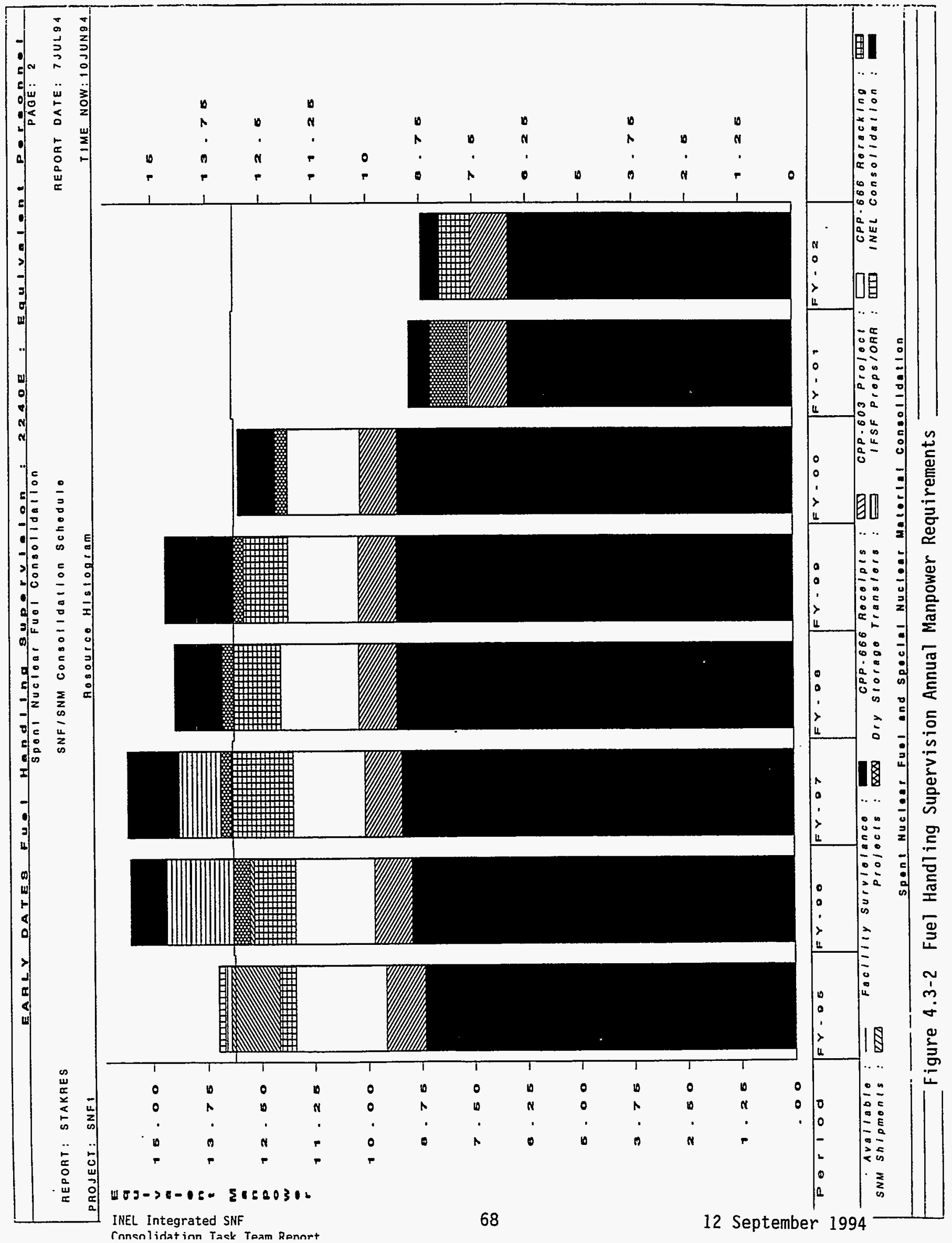




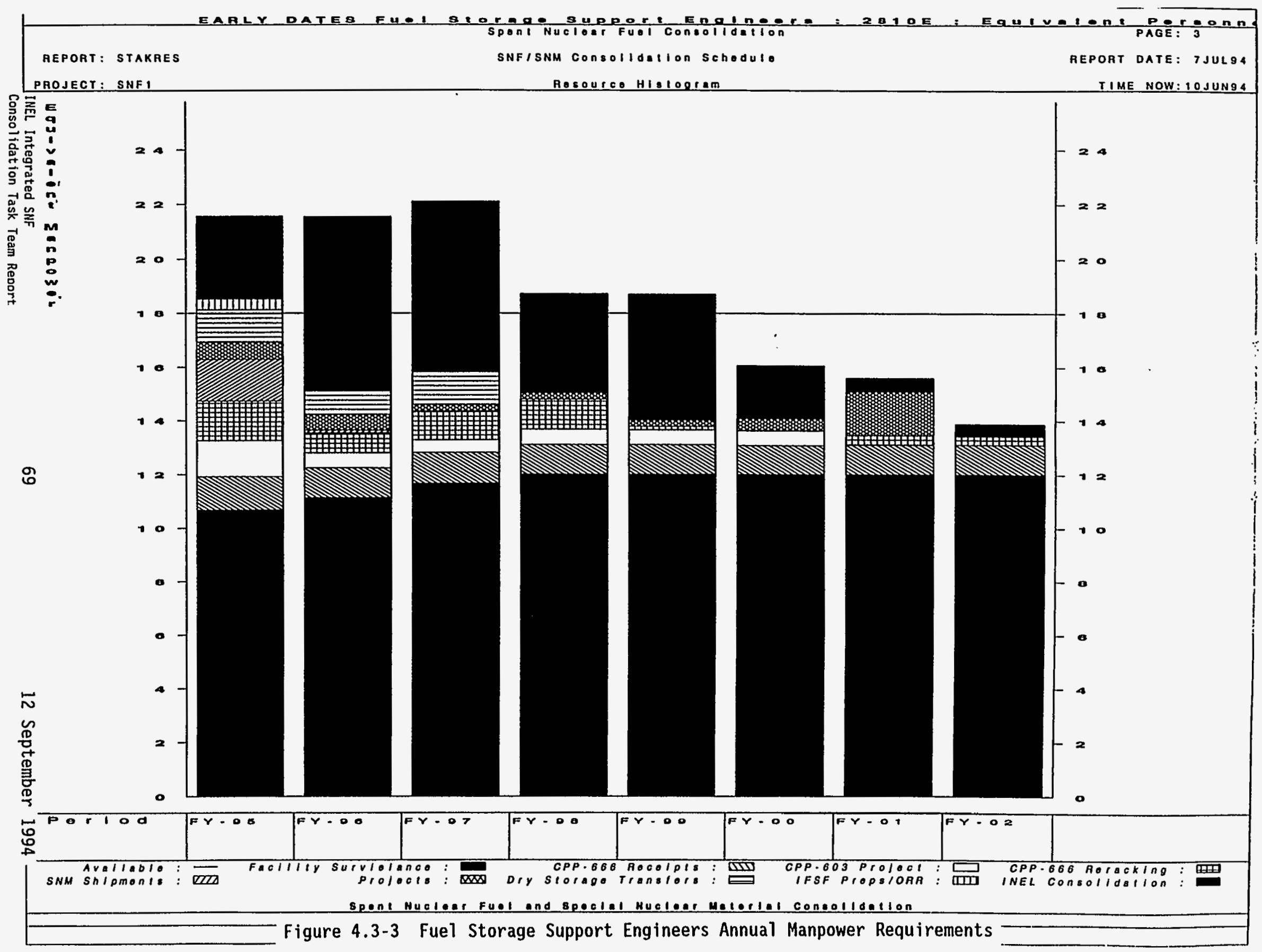




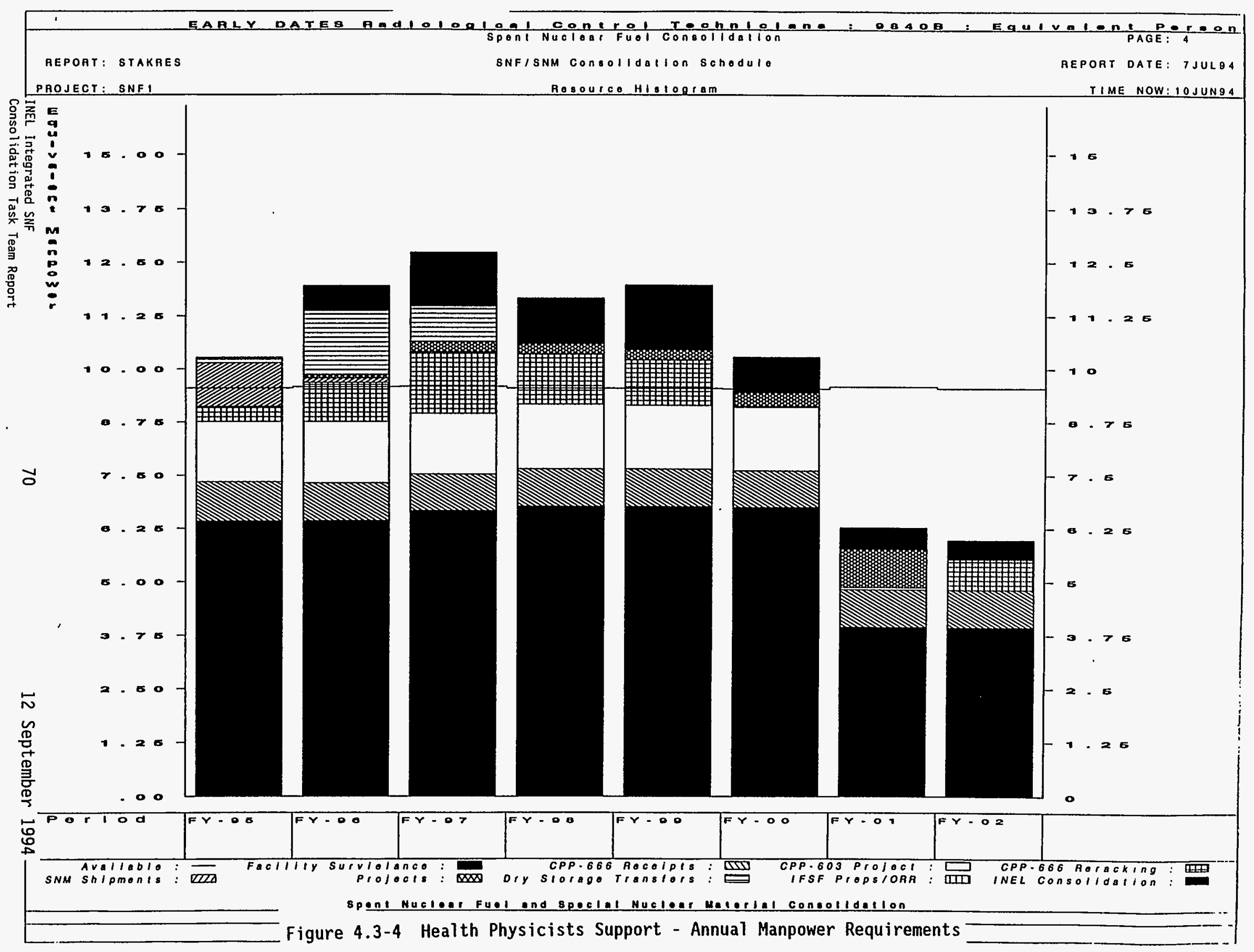


have been approved by DOE for use in transporting SNF to ICPP. Methods for safe transport are documented in DOE-approved transport plans for each type of SNF. The transfers proceed within the limits imposed by the plan. Transport Plans have been approved for NRF and ATR transfers and such transfers are common at the INEL. Transport Plans must be developed and approved for SNF transfers from PBF, ARMF/CFRMF, and the MTR canal.

Transfers of TMI core debris are expected to be in a cask that has been specifically licensed for transport. Transfer of casks that have a NRC Certification of Compliance is similar to shipping the cask to an off-site location. No other consideration is required except paper work for transfer. Transferring the LOFT SNF (via PB-2 cask) and the dry storage casks from TAN to ICPP involves the use of non-NRC Ticensed casks on a five-mile section of a state highway. The highway is outside the controlled boundaries of the INEL.

One method for meeting the DOT regulations is to obtain a DOT exemption. This is a procedure within the Code of Federal Regulations that uses administrative controls for equivalent safety, as approved by DOT.

Another method for shipping the PB-2 cask is to make the transfers "out-ofcommerce." This is another allowable procedure using DOE equipment and personnel.

A third method is to request permission from the state of Idaho to close the highway during the time (about one-hour) required to traverse that section of highway. Road closure could be performed by Idaho State Police. The cask would be moved at 5 to 15 miles per hour. Escort vehicles would be provided both ahead and behind the transporter for traffic control. Normal traffic would resume when the transporter left the state highway. A similar procedure has proven to be safe in the past.

\subsubsection{NEPA}

SNF transfer between facilities at the INEL is a routine activity. Existing facilities and components would generally be used (e.g., pools, hot shops, casks, transporters, etc.) for the proposed SNF consolidation transfers. The ICPP mission and the total INEL SNF storage capacity would remain essentially the same. Therefore, proposed SNF transfers would not require additional NEPA documentation. The cumulative effects of INEL SNF management and other ongoing INEL ER\&WM activities will be addressed in the ongoing EIS.

Proposed TAN pool stabilization activities and related ICPP above ground vaults and dry cask storage construction projects are being addressed in an existing draft EA. These activities can proceed upon issuance of a Finding of No Significant Impact.

\subsubsection{Safety Analyses}

Safety AnaTysis Reports (SARs) and Technical Safety Requirements (TSRs) must be prepared for each potential (existing and new) ICPP SNF storage facility. These safety analyses are needed in order to store the additional SNF or SNM. 
SARs and TSRs must be prepared in accordance with DOE Orders 5480.22 and 5480.23 . Technical specification and standards (TS/S) al so need to be revised for each existing and new facility. Each TS/S revision or new package costs approximately $\$ 40-\$ 55 K$.

Table 4.4-1 shows the estimated resources needed to complete the projected safety analyses requirements. It lists the storage facility, the affected fuel transfer, the estimated SAR/TSR cost, and time needed to prepare and obtain DOE approval. All time estimates are based on one person preparing the safety documents and obtaining DOE approval. The schedules could be shortened by using two or three people for each task. However, the review cycles represent 10-13 months in each estimate and cannot be significantly reduced.

If SNF is initially stored in one facility and subsequently moved to another, additional safety document revisions would be needed for the second facility. In general, once a safety analysis has been updated to DOE Orders 5480.22 and 5480.23 , subsequent revisions of SAR and TSR/TS/S packages can be prepared and approved by DOE for $\$ 70-\$ 90 \mathrm{~K}$ each. The update for the existing ICPP SNF storage facilities is assumed to occur independent of the SNF consolidation program.

Criticality safety evaluations (CSEs) need to be prepared for transporting, handling, and storing of each fuel type. A primary and independent CSE wi 1 be needed for each fuel type or designation. Independent reviews may range from a second analysis, complete with independent calculations, to a simple review of the methodology and assumptions, depending on the complexity of the analysis and the consequences of error. If a fuel is initially stored at one facility and later transferred to another one, new CSEs need to be generated. Each CSE is prepared at a cost of $\$ 45 \mathrm{~K}$ and requires 2.25 months to prepare. $A$ total of 10 CSES would be prepared for NMIS, ARMF/CFRMF, PBF, LOFT, and commercial SNF. The total cost for CSES for these transfers would be $\$ 450 \mathrm{~K}$.

It is estimated that the criticality safety analyses for MTR canal SNF would be equivalent to four CSEs or eight (total) with independent calculations. The total cost for criticality analysis of the MTR canal SNF would be about $\$ 360 \mathrm{~K}$.

\subsection{FUNDING PROFILES}

The funding profiles for implementing the base case were previously shown in Figure 3.1-2. The costs identified in this figure include the SNF/SNM consolidation activities that are integrated in this schedule (see

Table 1.4-1). Several of these tasks are already funded. Thus, the dotted ine in Figure 3.1-2 identifies new funding that is required to execute those tasks that are not current7y funded i.e., PBF, TRA MTR canal, TRA ARMF/CFRMF, TAN commercial. If the IFSF window shown in Figure 3.1-1 closes due to early transfers from the CPP- 603 south basin, then the total consolidation schedule will increase by about 12 months and $\$ 5.00 \mathrm{M}$ dollars over the as soon as possible base case. 
Table 4.4-1 Safety Analyses Resource Estimates

\begin{tabular}{|c|c|c|c|c|}
\hline $\begin{array}{l}\text { SNF Storage } \\
\text { Facility }\end{array}$ & Fue1 Transfer & $\begin{array}{c}\text { Cost } \\
\text { Shipper } \\
\text { Receiver }\end{array}$ & $\begin{array}{l}\text { SAR/TSR } \\
\text { Duration }\end{array}$ & $\begin{array}{c}\text { Documentation } \\
\text { Needed }\end{array}$ \\
\hline ICPP IFSF $^{8}$ & $\begin{array}{l}\text { TRA MTR Cana1, PBF, } \\
\text { ARMF/CFRMF }\end{array}$ & $\begin{array}{c}\$ 1,352 \mathrm{~K} \\
\$ 377 \mathrm{~K}\end{array}$ & 12 months & $\begin{array}{c}\text { SAR, TSR, } \\
\text { TS/S, }\end{array}$ \\
\hline $\mathrm{CPP}-749^{\circ}$ & TAN LOFT & $\begin{array}{l}\$ 15 K \\
\$ 121 K\end{array}$ & 12 months $^{6}$ & $\begin{array}{l}\text { SAR, TSR, } \\
\text { TS/S, CSE }\end{array}$ \\
\hline $\mathrm{CPP}-651^{8}$ & TRA NMIS & $\begin{array}{l}\$ 0 \mathrm{~K} \\
\$ 126 \mathrm{~K}\end{array}$ & 12 months $^{b}$ & $\begin{array}{l}\text { SAR, TSR, } \\
\text { TS/S, CSE }\end{array}$ \\
\hline$C P P-666^{\circ}$ & $\begin{array}{l}\text { potential storage } \\
\text { area }\end{array}$ & $\$ 217 \mathrm{~K}$ & 9 months & $\begin{array}{l}\text { SAR, TS } / S, \\
\text { CSE for each } \\
\text { fuel }\end{array}$ \\
\hline $\begin{array}{l}\text { New, cask } \\
\text { storage pad }\end{array}$ & TAN commercial SNF & $\begin{array}{l}\$ 44 \mathrm{~K} \\
\$ 218 \mathrm{~K}\end{array}$ & 30 months & $\begin{array}{l}\text { PSAR, FSAR, } \\
\text { TSR, TS/S CSE }\end{array}$ \\
\hline $\begin{array}{l}\text { New, } \\
\text { aboveground } \\
\text { storage } \\
\text { vaults }\end{array}$ & TAN TMI & $\$ 250 \mathrm{~K}$ & 24 months & $\begin{array}{l}\text { PSAR, FSAR, } \\
\text { TSR, TS/S }\end{array}$ \\
\hline $\begin{array}{l}\text { Fuel } \\
\text { transport } \\
\text { containers }\end{array}$ & & $\$ 120 \mathrm{~K} /$ fue & $\begin{array}{l}18 \text { months/ } \\
\text { fuel }\end{array}$ & $\begin{array}{c}\text { SAR, TSR, } \\
\text { TS/S, CSE for } \\
\text { each fueT and } \\
\text { each } \\
\text { container }\end{array}$ \\
\hline
\end{tabular}

(a) Assumes the task of updating existing safety documentation to DOE orders 5480.22 and 5480.23 are accomplished independent of this SNF consolidation program. Thus, the cost estimates support the analysis that is only associated with the consolidation program.

(b) Requires a safety analysis engineer who is fulty dedicated to this task.

\subsection{RESOURCE CONSERVATION}

Additional conservation of key resources may be obtained by completing the integration of the partially-integrated, SNF consolidation projects. The Task Team already developed resource conservation in the areas of Receiver's human resources, facilities and equipment, and Shipper's equipment. Additional resource conservation benefits may be obtained by evaluating the SNF consolidation as a single project entity with common administration and oversight. The CSE/SAR compliance program, the ORA/ORR compliance program, the SNF handiing tool design and construction program, and the Shipper/Receiver SNF handling teams are areas where similar resources, now assigned to separate activities, could be combined. 
This page left blank intentionally.

INEL Integrated SNF

Consolidation Task Team Report NH-CS1.WPD/TC/K:/SP\&I 


\subsection{INEL SNF CONSOLIDATION ISSUES AND RISKS}

Several issues and risks related to SNF consolidation were identified that could adversely affect the proposed INEL SNF consolidation schedule. These issues and risks are presented in Table 5.1-1 and involve project funding, documentation approvals, facility adequacy, equipment readiness, and transportation.

\subsection{TECHNICAL RISKS}

The technical risk for transferring SNF or SNM from facilities at NRF, TRA, PBF, and TAN to facilities at ICPP for the purpose of deactivating aged or surplus INEL SNF storage facilities is relatively low. The low risk is due to: (1) the administrative and technical expertise that is available to support the plan, (2) the priority assigned to this SNF consolidation mission, and $(3)$ the 40 years of experience that exist with related SNF management activities.

\subsection{MANAGEMENT RISKS}

Management risks are conditions that could adversely affect the schedule, cost, or product quality of the SNF consolidation plan. Management risks associated with the related activities have been reported recently as vulnerabilities, issues, or concerns by several assessment teams in the past year. However, most of these have identified resolutions planned and are not listed in this document.

\subsection{OTHER POTENTIAL CONSOLIDATION INVENTORIES}

The impact of other SNF receipts from outside the INEL has not been addressed because of time Timitations. However, the Open Plan ${ }^{\mathrm{m}}$ software is designed to identify the impacts of any SNF receipt scenario.

New SNF receipt scenarios that may be of interest could include the impact of receiving foreign research reactor fuel (potential for near-term shipment of 6,000 elements; possibly stored in IFSF). Other scenarios can be generated by the Programmatic SNF and INEL ER\&WM EIS ROD, e.g., centralization of all SNF at the INEL, transfer of INEL SNF to another site, or centralization of Uranium-233 (U-233) at the INEL. The following paragraphs discuss some specific SNF transfers that are likely to continue to be real possibilities and may justify further investigation.

\subsubsection{INEL Radioactive Waste Management Complex (RWMC) U-233}

$\mathrm{U}-233$ is stored at two sites in the DOE complex and is another potential candidate for consolidation. Essentially a 17 of the U-233 remaining in the complex is stored at INEL and Oak Ridge Y-12 Plant. Storage 1ocations at INEL are the RWMC and ICPP. Consolidation of these weapons capable/useable inventories may be advantageous, but are not included in the SNF consolidation analyses or in this plan. 


\begin{tabular}{|c|c|}
\hline ISSUE & STRATEGY \\
\hline $\begin{array}{l}\text { A. The FY-96 budget planning packages submitted do not } \\
\text { include FY-95 funding for critical path activities } \\
\text { that are needed to support the proposed schedule for } \\
\text { relocating SNF from PBF and MTR canal to ICPP. }\end{array}$ & $\begin{array}{l}\text { The problem of earlier funding needs, } \\
\text { (particularly for the MTR canal SNF) has been } \\
\text { identified to DOE management. Finding } \\
\text { funding for the early activities could } \\
\text { alleviate this issue. }\end{array}$ \\
\hline $\begin{array}{l}\text { B. A quantitative limit for moisture in SNF dry storage } \\
\text { cans is needed to optimize the drying process. }\end{array}$ & $\begin{array}{l}\text { SNF dry demonstration programs are scheduled } \\
\text { to determine the effects of moisture that is } \\
\text { present after use of conventional SNF drying } \\
\text { techniques and validate estimated drying } \\
\text { time. }\end{array}$ \\
\hline $\begin{array}{l}\text { C. An assessment of hazards is needed to determine dry } \\
\text { storage requirements for SNF encased in the epoxy } \\
\text { matrix used in metallurgical sample preparation. }\end{array}$ & $\begin{array}{l}\text { SNF dry storage demonstration programs will } \\
\text { be used to assess these hazards and minimize } \\
\text { the risks. }\end{array}$ \\
\hline $\begin{array}{l}\text { DNF stored at INEL is controlled by several DOE } \\
\text { organizations. Considerable coordination will be } \\
\text { required to develop agreement among the different } \\
\text { organizations and with stakeholders for consistent } \\
\text { criteria for storage and transport of the SNF. }\end{array}$ & $\begin{array}{l}\text { DOE-ID will follow up on discussions with DP, } \\
\text { NE, RW, EM, and stakeholders to reach } \\
\text { agreement regarding these facilities and the } \\
\text { consolidation plan. }\end{array}$ \\
\hline $\begin{array}{l}\text { E. The CPP- } 749 \text { gantry crane is old and has not been } \\
\text { operated for some time; therefore, its condition is } \\
\text { unknown. Also, vendor support is no longer } \\
\text { availabie, so repairs and maintenance may prove } \\
\text { difficult. }\end{array}$ & $\begin{array}{l}\text { Inspect the crane for operability and monitor } \\
\text { its condition. The unit should be replaced } \\
\text { if warranted, and vendor support should be } \\
\text { arranged. }\end{array}$ \\
\hline $\begin{array}{l}\text { F. The proposed transfer of TAN LOFT and TAN commercial } \\
\text { SNF to ICPP will use a short stretch of a state } \\
\text { highway within the INEL boundaries, which normally } \\
\text { requires the use of certified transport cask systems. }\end{array}$ & $\begin{array}{l}\text { Preliminary discussion with DOE-ID indicates } \\
\text { that DOT exemptions or other "out-of- } \\
\text { commerce" transfer procedures may be } \\
\text { obtainable. These procedures are permissible } \\
\text { under the provisions of the INEL } \\
\text { Transportation Safety Manual and DOT } \\
\text { regulations. }\end{array}$ \\
\hline
\end{tabular}


Table 5.1-1. INEL SNF Consolidation Issues and Risks (Continued)

\begin{tabular}{|c|c|}
\hline ISSUE & STRATEGY \\
\hline $\begin{array}{l}\text { G. Significant changes in the requirements for the TAN } \\
\text { TMI SNF Dry Cask Storage Project have occurred or are } \\
\text { being considered so that: } \\
\text { (1) Some critical path work is on hold, and } \\
\text { (2) Some project planning documentation may need to } \\
\text { be updated. }\end{array}$ & $\begin{array}{l}\text { The strategy is: 1) Continue hold on } \\
\text { critical path work pending review of options } \\
\text { at ICPP, 2) Develop above ground vault } \\
\text { concept at ICPP for storage, 3) Seek approval } \\
\text { of revised EA, and 4) Resume design after EA } \\
\text { approval. }\end{array}$ \\
\hline $\begin{array}{l}\text { H. The eligibility of the TFBP-2 cask for the PBF and } \\
\text { ARMF/CFRMF transfers needs to be verified early to } \\
\text { validate the proposed SNF consolidation plan and to } \\
\text { ensure that the planned modification of the IFSF } \\
\text { Transfer Cart is appropriate. }\end{array}$ & $\begin{array}{l}\text { Transfer the TFBP-2 cask to TAN for } \\
\text { inspection and maintenance as soon as } \\
\text { possible (prioritize funding if necessary). }\end{array}$ \\
\hline $\begin{array}{l}\text { I. The DOE Spent Fuel Working Group identified two } \\
\text { vulnerabilities (from seismic events and ventilation } \\
\text { system malfunction) for SNF stored at IFSF, which } \\
\text { may delay facility readiness for receipt of } \\
\text { additional SNF. }\end{array}$ & $\begin{array}{l}\text { A study is underway to assess the perceived } \\
\text { inadequacy in seismic resistance of the IFSF } \\
\text { concrete structure including the roof and the } \\
\text { fuel storage rack inside the IFSF storage } \\
\text { vault. } \\
\text { An electrical upgrade is in progress and } \\
\text { should be completed by 0ctober } 1994 \text { to } \\
\text { resolve the ventilation system issue. }\end{array}$ \\
\hline $\begin{array}{l}\text { J. The IFSF transfer cart must be modified to interface } \\
\text { with the TFBP-2 cask. }\end{array}$ & $\begin{array}{l}\text { Design, build, or modify adapter plate used } \\
\text { in the IFSF transfer cart. }\end{array}$ \\
\hline $\begin{array}{l}\text { K. A resumption of shipments of graphite SNF from Fort } \\
\text { St. Vrain would compromise availability of dry } \\
\text { storage space in IFSF, which is planned for INEL SNF } \\
\text { consolidation use. }\end{array}$ & $\begin{array}{l}\text { Monitor the potential for shipping the Ft. } \\
\text { St. Vrain fuel. Should shipments resume, } \\
\text { alternate storage for some consolidation SNF } \\
\text { would be required and continue to evaluate } \\
\text { options that provide maximum safety for all } \\
\text { stored SNF. }\end{array}$ \\
\hline
\end{tabular}


Uranium waste (major isotope U-233) was received from the Bettis Atomic Power Laboratory as transuranic waste following the experimental development of the Light Water Breeder Reactor. Because of the decay products of U-233, this material may now exceed the gamma radiation limit for contact handling. This material is stored at the RWMC in several configurations in the Transuranic Storage Area and the Intermediate-Level Transuranic Storage Facility. Some storage containers (68-55 gallon barrels 6M, and 77-110 gallon barrels 6M) contain unirradiated pellets and fuel rods. Most of the containers (about 170055 gallon barrels) contain fabrication scrap material. The unirradiated pellets and rods contain about $34 \mathrm{~kg} \mathrm{U}-233$.

\subsubsection{Oak Ridge Y-12 Plant U-233}

The Radiochemical Development Facility, Building 3019 at the $Y-12$ Plant, has served as the national repository for U-233 since 1963 . The facility was constructed in 1943 to support uranium and plutonium recovery processes at Hanford. A shielded cell was modified for U-233 storage. Additional storage capacity was gained by drilling wells within the surrounding concrete cell walls. This inventory, resulting from experiments associated with pilot testing of the thorium fuel cycle, consists of approximately $423 \mathrm{~kg} \mathrm{U}-233$ and $1380 \mathrm{~kg}$ total uranium. The material has been chemically separated from thorium fuel cycle materials, solidified to an oxide form, and is stored in approximately 1000 cans.

The facility is reaching its end of useful life for this role. Additionally, some of its equipment is not adequately shielded for the energetic gamma radiation building-up from the decay of associated U-232. Thus, DOE-DP is evaluating options for continued storage, potential consolidation, and/or disposal of this material. If the INEL can accept this inventory in an existing facility (CPP-651 and/or TRA-620, for example), the cost advantage over new construction would be significant. Thus, the complex-wide consolidation of this material at INEL is a future possibility, but outside the scope of this plan.

\subsubsection{INEL ICPP U-233}

Uranium-233 is stored at ICPP in the form of irradiated and unirradiated fuel elements. These fuels are stored in the IFSF and in the CPP-749 Dry Vaults. The IFSF was constructed specifically for the receipt and storage of Fort St. Vrain fuel in 1974, and the dry vaults were constructed in the mid-1980s. Approximately $318 \mathrm{~kg} \mathrm{U}-233$ is stored as unirradiated Light Water Breeder Reactor fuel. Irradiated fuels from Fort St. Vrain reactor, Peach Bottom reactor (high-temperature gas cooled), and the Light Water Breeder Reactor program contain $645 \mathrm{~kg} \mathrm{U-233.}$ 


\subsubsection{ATR SNF TRANSFERS FOR CORROSION STUDIES}

Three ATR SNF elements are proposed to be destructively examined to assess the impacts of their post storage environments. One SNF element recently discharged from ATR will be used to benchmark the impacts of two storage situations at ICPP (i.e., one ATR SNF element will be examined from the CPP-666 storage area, and one ATR SNF element will be examined from the CPP603 storage area). When the SNF examination facility is selected, each of these ATR elements will be scheduled for transfer. 
This page left blank intentionally. 


\subsection{REMAINING CONCERNS AND ISSUES, AND POTENTIAL RESOLUTIONS}

\subsection{CRITICAL PATH ISSUES}

If the consolidation schedule is implemented as proposed, there are several critical path issues that must receive prompt funding and checkout. This immediate action is needed to help assure completion INEL SNF consolidation as proposed. They would include:

- Checkout of the TFBP-2 cask; $\$ 0$ in FY-94 and $\$ 135,000$ in FY-95 .

- IFSF transfer cart adapter plate; $\$ 12,000$ in FY-94 and $\$ 126,000$ in FY -95

- SNF canister design and testing; $\$ 0$ in FY-94 and $\$ 179,000$ in FY-95

- Documentation - immediate start on SAR updates via modifications to existing WINCO support contracts for SAR update activities

\subsection{SCHEDULE OWNERSHIP AND MAINTENANCE}

It is recommended that this $\mathrm{plan}$ be $\mathrm{placed}$ under the control and ownership of ICPP Fuel Storage Planning. This group is headed by R. E. Cottam. He has played a lead role in the development of this plan, and supported R. J. Freeman (lead program scheduler) with input to the Open PTan ${ }^{\text {mM }}$ software. Contacts from each of the prospective EG\&G SNF storage area include: $D$. W. Colling - PBF; A. H. Clark - ARMF/CFRMF; A. H. Clark - MTR canal; and R. K. Elwood - TAN. 


\section{REFERENCES}

Britschgi, J. J. notegram to B.D. Patton, March 2, 1994.

Brolin, E. E. letter to A. A. Pitrolo, Power Burst Facility (PBF) Management Options, January 11, 1994.

Buckland, R. J. et al, 1993, INEL D\&D Long-Range Plan, October 1993.

Burdick, E. E., Fast, E., and Knight, D. W., The Advanced Reactivity Measurement Facilities, A Description and Performance Evaluation, Phillips Petroleum Co. Report Number IDO-17005, October 1964.

Burns Jr., T. F. letter to E. N. Fray and W. C. Moffitt, AM/OPA-SSD-SMM-94052, Task Team Report - Consolidation of TRA and ICPP Special Nuclear Materials in CPP-651, Apri] 7, 1994.

Burns Jr., T. F. letter to E. N. Fray and W. C. Moffitt, AM/OPA-SSD-SMM-94076, Consolidation of TRA and ICPP Special Nuclear Materials in CPP-651, June $20,1994$.

Dials, G. E. Tetter to E. N. Fray and W. C. Moffitt, AM/OPA-SSD-SMM-93-033, Joint EG\&G-WINCO Cost/Benefit Study - Consolidation of Special Nuclear Materials, November 8, 1993.

EG\&G Idaho, 1993, Idaho National Engineering Laboratory Installation Roadmap Document, DOE/ID-10405, Rev. 1, May 1993.

Grumbly, T. P. Tetter to Acting Director of Nuclear Energy, NE-1, Iransition of the Power Burst Facility, December 6, 1993.

Hamer Jr., D. L. letter to W. C. Moffitt, OPE-SNF-WJM-93067, Program Execution Guidance for Site Fuel Consolidation, December 29, 1993.

Henry, R. N. letter to Distribution, WINCO Validation Meeting Report, Hen-33-94, July 6, 1994.

Henry, R. N. Tetter to Distribution, Meeting Report, Hen-22-94, May 18, 1994.

Henry, R. N. et al., 1993, Interim Report of the INEL Spent Nuclear Fuel Consolidation Task Team, WIN-367, October 1993.

Hevlow, J. E. et al, 1994, Task Team Report - Consolidation of TRA and ICPP Special Nuclear Materials in CPP-651, February 28, 1994.

Johnson, E. R., and Notz, K. J., Shipping and Storage Cask Data for Spent Nuclear Fuel, ORNL/TM-11008, November 1988.

Kaletä, J. S., Chief Counsel, Research and Special Programs Administration, U.S. Department of Transportation letter to Denny, S. H., Director, Transportation Management Program, Office of Technology Development U.S. Department of Energy, Apri7 23, 1991. 


\section{REFERENCES (Continued)}

LaBuy, S. A., ARMF/CRMF Fuel Characterization Report, EDF-TRA-ATR-959, May 12, 1994.

LaBuy, S. A., ARMF/CFRMF Fuel Removal Program P1an, PG-T-94-004, May 12, 1994.

LaBuy, S. A., MTR Canal Fuel Characterization Report, EDF-TRA-ATR-958, May 12, 1994.

LaBuy, S. A., and Shaber, E. L., MTR Fuel Removal Program Plan, Report Number PG-T-94-003, Revision 0, April 27, 1994.

Leatham, J., Project Management Plan for Fuel Relocation and Stand-Doron of . the Power Burst Facility, PG-T-94-005, May 23, 1994.

Moffitt, W. C. letter to T. F. Burns, Task Team Report-Consolidation of TRA and ICPP Special Nuclear Materials in CPP-651, WCM-69-94, February 28, 1994.

Moffitt, W. C. letter to T. F. Burns, Consolidation of TRA and ICPP Special Nuclear Materials in CPP-651, WCM-127-94, Apri7 14, 1994.

Patton, B. D. presentation at Y-12 plant, April 1994.

Pierce, T. M. letter to W. C. McQuiston, TMP-096-93, INEL Risk Based Prioritization Program, December 2, 1993.

Pruss, C. A., LWBR Fuel Disposal Engineering, NRF Project, Westinghouse Electric Corporation, letter to Manager, Pittsburgh Naval Reactors Office, U.S. Department of Energy, Safety Analys is for INEL On-Site LWBR Shipments Using the Peach Bottom PB-2 Shipping Container, October 9, 1985.

Thermal Fuels Behavior Program Irradiated Hardware Transport System Transport Plan (TFBP-2), Specification Number ES-50526 D, May 9, 1986.

U.S. DOE, 1993, DOE Integrated Spent Nuclear Fuel Program Pian, SNF-5000-120-002, October 1993.

U.S. DOE, 1993, Spent Fuel Working Group Report on Inventory and Storage of the Department's Spent Nuclear Fuel and Other Reactor Irradiated Nuclear Materials and Their Environmental, Safety, and Health Vulnerabilities, December 7, 1993.

U.S. DOE, 1994, Plan of Action to Resolve Spent Nuclear Fuel Vulnerabilities, Phase 1; Volume 1 Executive Summary and Volume II, February 1994.

U.S. Nuclear Regulatory Commission, Certificate of Compliance Number 9015, Package Ident ification Number USA/9015/B( ), Transnuclear, Inc. TN-8 and TN-8L Casks, Revision 127, May 17, 1991.

Van Deusen, L. C. letter to L. A. Green, U-233 "White Paper", LCV-178-93, December 20, 1993. 
Spent nuclear fuel (SNF) is in various types of storage configurations at several different INEL facilities including: Power Burst Facility (PBF), Test Reactor Area (TRA), Test Area North (TAN), Idaho Chemical Processing Plant (ICPP), Argonne National Laboratory-West (ANL-W), and Naval Reactor Facility (NRF). SNF specifically proposed for transfer to the ICPP for consolidation of the INEL SNF inventory. Therefore, ICPP, ANL-W and NRF inventories are not listed here.

SNF inventory data from all INEL locations is stored in a database system. The database includes detailed descriptions of the fissile material amounts and storage locations. The inventories have been checked to ensure they are consistent with the accountability inventories in the Nuclear Materials Management and Safeguards System. The information on pages A-2 and A-3 was gleaned from data assembled by the National Spent Nuclear Fuel Support organization at the INEL. 
INEL SNF Inventories as of

January 1, 1994

TAN

TAN POOT

Metric tons of heavy metal

TMI-2 Core debris ................. . . . . . . . . . . . . . . . . . . . .

LOFT fuel .................... . . . . . . . . . . . . . . . . . . . .

Commercial type fuel rods ................. . . 1.164

Loose fuel rod storage basket ............. . . 0.312

sub total 85.249

TAN Test Pad

PWR intact and consolidated assemblies . . . . . . . . . 38.370

TAN total 123.619

TRA

ATR Fuel Assemblies

In the reactor .................. 0.046

Awaiting shipment to ICPP . . . . . . . . . . . . . . . . . . . . . . 0.094

Recyclable........................... 0.585

MTR Canal Tight Water Reactor fuel rods and pieces

sub total 0.725

Commercial fuel rods in cans,

PBF Driver Core rods in cans, and

other test fuel rods in cans.............. . . 0.257

ARMF/CFRMF Canal

MTR-type fuel assemblies................ . . . . 0.231

TRA total 1.213

$\underline{\text { PBF }}$

PBF Canal

Power Burst Facility Driver Core fuel rods . . . . . . . .

PBF total 0.834

INEL Integrated SNF

Conso lidation Task Team Report

12 September 1994

NH-CS2.WPD/TC/K:/SP\&I

A-2 
Table A-1 Detailed Characteristics Of SNF Proposed For INEL Consolidation

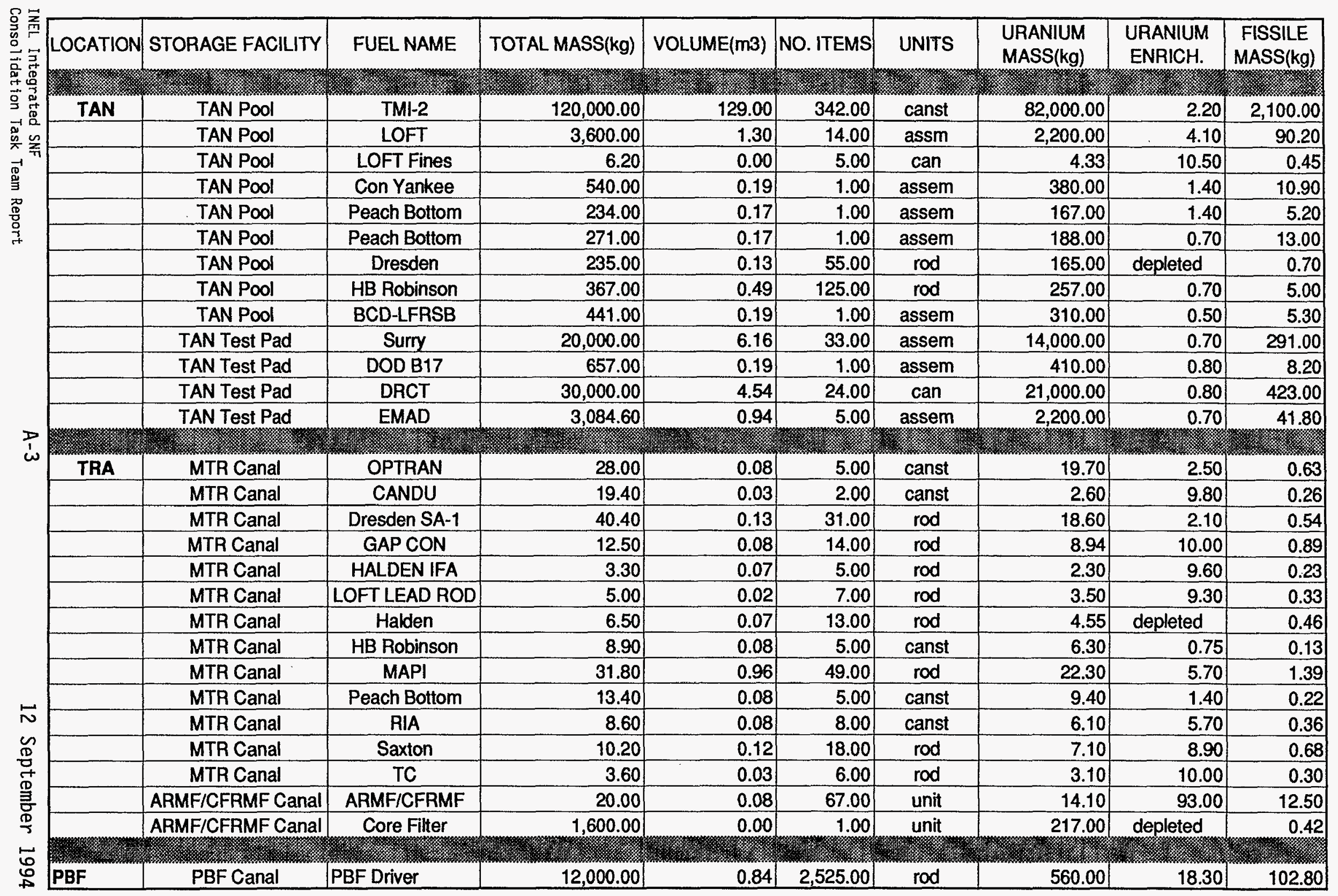




\section{TASK TEAM MEMBERSHIP AND RESPONSIBILITIES}

At the direction of the Department of Energy, Idaho Operations Office, Westinghouse Idaho Nuclear, Inc. formed a multi-discipline, INEL-wide task team to produce this report. Knowledgeable and experienced INEL personnel provided the detail and insight necessary to scope the issues and provide the complex planning strategy for SNF consolidation. Representatives from the State (Idaho) Oversight Committee and DOE-ID were al so included in the development of this draft plan. The task team organization is presented on Figure B-1.

Core team members were responsible for overall guidance of the report, interface within their company, developing the assumptions, creating and validating the work packages and schedules, identifying critical path issues and possible resolutions, and contractor review and concurrence of this report. People were called upon, as needed, to provide information in their area of expertise. The overall participation of this effort is shown in Figure B-2. 


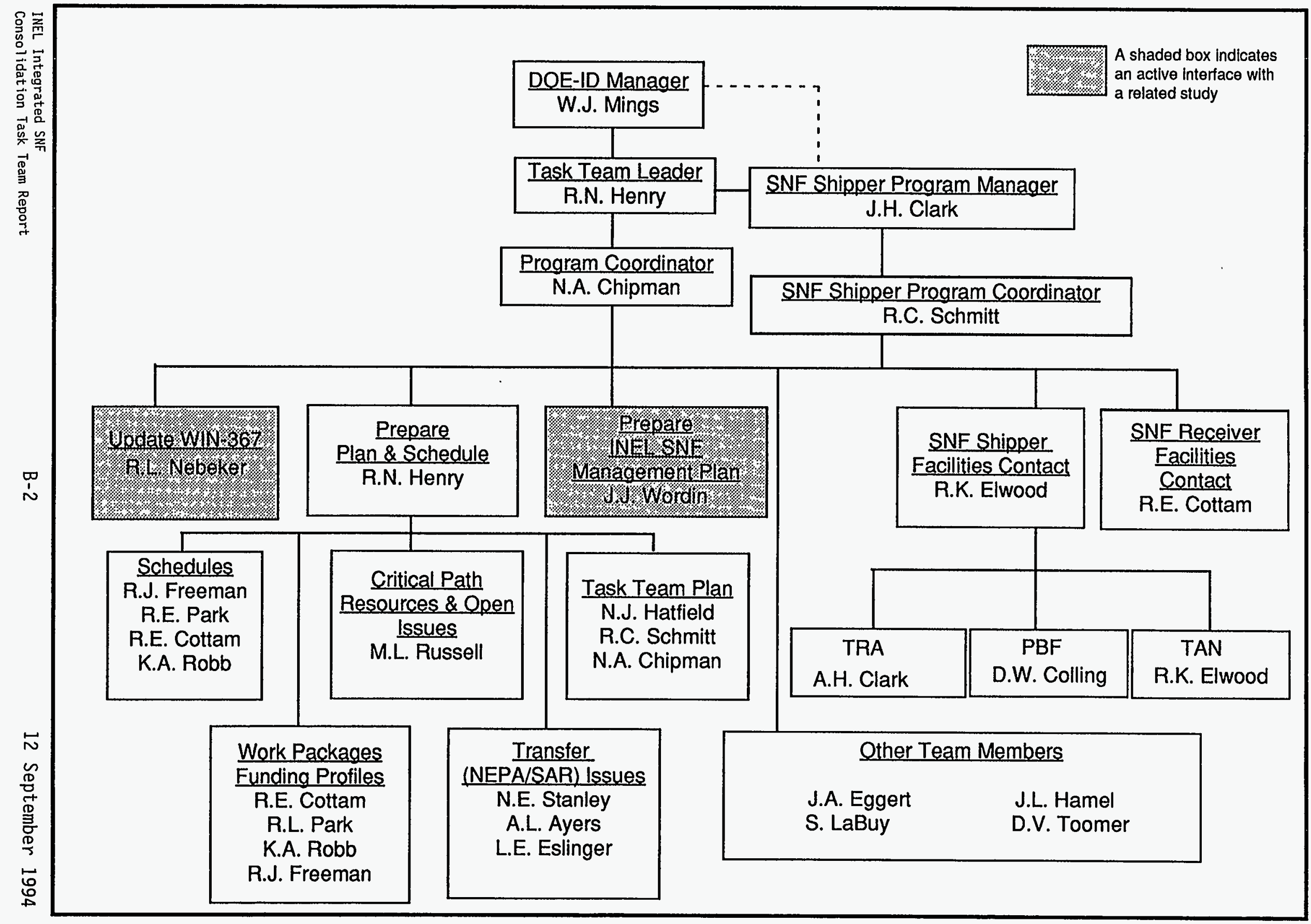

Figure B-1. INEL Integrated SNF Consolidation Task Team Organization 


\begin{tabular}{|c|c|c|c|}
\hline - & Phone & & Phone \\
\hline $416 \%$ & & m & \\
\hline Roger Henry & $6-1223$ & Jack Clark & $6-8879$ \\
\hline Nate Chipman & $6-1424$ & Dick Schmitt & $6-1837$ \\
\hline Bob Nebeker & $6-0572$ & Jerry Leatham & $6-9253$ \\
\hline Clair Fitch & $6-1567$ & M.L. (Bud) Russell & $6-9516$ \\
\hline Russ Cottam & $6-5791$ & Mike Tyacke & $6-1601$ \\
\hline Doug Toomer & $6-3009$ & Randy Elwood & $6-6708$ \\
\hline Alan Robb & $6-5395$ & Al Clark & $6-4370$ \\
\hline Jim Eggert & $6-0021$ & Evelyn Ockerman & $6-1015$ \\
\hline Gary Offutt & $6-3014$ & Norm Stanley & $6-5901$ \\
\hline Bruce Angle & $6-1841$ & Scott LaBuy & $6-9856$ \\
\hline Jenny Hamel & $6-0084$ & Ken Moor & $6-8810$ \\
\hline Bob Freeman & $5-0019$ & Lee Eslinger & $6-9633$ \\
\hline Ron Denney & $6-3102$ & A.L. (Ron) Ayers & $6-4419$ \\
\hline Jim Carter & $6-4406$ & Bob Norris & $6-6545$ \\
\hline Leo Mondok & $6-3012$ & Lee Tuott & $6-7990$ \\
\hline Sean Finnigan & $6-5840$ & Dan Colling & $6-8395$ \\
\hline Tink Lockhart & $6-1139$ & Bob Park & $6-9130$ \\
\hline Lynn Goldman & $6-0952$ & John Irving & $6-8745$ \\
\hline Roy Gale & $5-0021$ & Tom Fewell & $6-8830$ \\
\hline Maris Cukurs & $5-5953$ & Henry Welland & $6-9375$ \\
\hline Allan Christensen & $6-3666$ & Eileen Yokunda & $6-6728$ \\
\hline John Wordin & $6-0310$ & Helmut Worle & $6-8963$ \\
\hline Dave Peters & $6-8116$ & John W. Rice, Jr & $6-4206$ \\
\hline Joe Carlson & $5-5792$ & J. Blair Briggs & $6-7628$ \\
\hline Nancy Hatfield & $6-8196$ & Arlo Summers & $6-8259$ \\
\hline Matt Ebner & $6-3089$ & Dan Golden & $6-0460$ \\
\hline David Lord & $6-2959$ & Eric Shaber & 6.8145 \\
\hline Denny Fillmore & $6-3690$ & Allan Bringhurst & $6-8909$ \\
\hline David Ostby & $5-0015$ & Ron Peterson & $6-8960$ \\
\hline Bill Dirk & $6-3078$ & Meg Galster & $6-7546$ \\
\hline Larry Dausin & $6-0517$ & W.L. (LeW) Powell & $3-4362$ \\
\hline Roy Campbell & $6-1395$ & Gina Ban & 5-0619 \\
\hline Todd Taylor & $6-9656$ & Mike Sprenger & $6-5866$ \\
\hline Mike Caldwell & $6-8967$ & Scott Spaulding & $6-2777$ \\
\hline Claude Kimball & $6-3695$ & Bert Bames & $6-6355$ \\
\hline Bob Kirkham & $6-3896$ & & \\
\hline Fred Roth & $6-9198$ & - & \\
\hline Dennis Pulsipher & $6-7540$ & Elmer Johnson & 6-1882 \\
\hline James Murphy & $6-4453$ & & \\
\hline Merle Jackson & $6-5263$ & 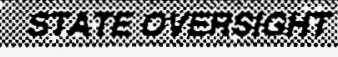 & \\
\hline E.G. (Snuffy) Adams & $6-3466$ & Robert Kress & $8-2600$ \\
\hline Gordon Johnson & $6-5104$ & Nick Wade & $8-2623$ \\
\hline Corey Beebe & $6-9172$ & & \\
\hline J.Stone & $6-7103$ & $\%=1 \%$ & \\
\hline Mike Beer & $5-5761$ & Betsy Silver & $6-1030$ \\
\hline Edward Armstrong & $6-3032$ & Mike Kuprenas & $3-5316$ \\
\hline Seeley Magnani & $6-5958$ & & \\
\hline
\end{tabular}

Figure B-2 INEL SNF Consolidation Task Team Overal1 Participation 
Appendix C

PLAN ASSUMPTIONS

This section identifies assumptions that established a frame of reference, or planning basis for the subsequent analysis of Idaho National Engineering Laboratory (INEL) Spent Nuclear Fuel (SNF) and Special Nuclear Material (SNM) consolidation at the Idaho Chemical Processing Plant (ICPP). From this planning basis, cost estimates, secondary planning assumptions, and schedules for consolidation efforts were developed. Secondary assumptions are listed on the summary tables in subsection 2.4 and in the Planning Package Cost Account and Work Package Statements in Appendix D. Thus, the following assumptions were implemented to initiate the planning/scheduling process, and they do not include contingencies for uncertainties in the technical, cost, or budget baselines.

OVERALL --

1. Safety will have the highest priority.

2. INEL SNF and SNM will be consolidated at the ICPP as soon as possible to resolve environmental, safety, and health (ES\&H) vulnerability assessment issues.

3. The INEL will receive SNF at previously predicted rates as soon as the Programmatic Spent Nuclear Fuel and INEL ER\&WM Environmental Impact Statement (Programmatic SNF and INEL ER\&WM EIS) is completed. That is, Navy fuel receipts continue and a11 other SNF shipments resume January 1 , 1997. SNF receipts during the consolidation period wi11 be bounded by: 1) Navy per their 40 year forecast, 2) INEL operating reactors (Advanced Test Reactor [ATR]), and 3) Off-site research and development SNF (10\% of university and foreign research and development reactors are too small to impact the overall SNF consolidation schedule).

4. The initiating baseline priority of SNF and SNM receipt at ICPP facilities is:

1) transfers from CPP-603 wet storage, 2) Naval Reactor Facility, 3) ATR, 4) Rover-Bed, 5) Nuclear Material Inspection and Storage Test Reactors Area (TRA) SNM, 6) CPP-749 transfers (Fermi and Peach Bottom), 7) ICPP Dry Storage Demonstration Project, 8) TRA Materials Test Reactor Canal, 9) TRA Advanced Reactivity Measurement Facility/Coupled Fast Reactivity Measurement Facility, 10) Power Burst Facility Canal, 11) TAN Three Mile Island, 12) TAN Loss-ofFluid Test, 13) TAN commercial, 14) Naval Reactor Facility Thermal Test Reactor, and 15) Argonne National Laboratory-West. The priority of the transfers can be expected to change as the Task Team and U.S. Department of Energy-Idaho Operations Office develop new insights. 
5. Commitments described in the:

- draft Programmatic SNF and INEL ER\&WM EIS,

- ICPP Spent Fuel and Waste Management Technology Development Program Plan,

- EM-351 Spent FueT Strategy document, and;

will be implemented as scheduled, or revised in advance, with DOE and State of Idaho agreement.

6. Previous7y approved INEL transport systems will be used for on-site movement of SNF and SNM. That is, interfacility transfers within the boundaries of the INEL may be in non-certified casks subject to traditional INEL regulations. Exemptions will be required for at least three transfers of SNF-7oaded dry storage casks and the LOFT transfers from TAN to ICPP.

7. SNM and SNF will continue to be defined and governed by the amended Atomic Energy Act of 1954 and the Nuclear Waste Policy Act. The term definitions are:

Special Nuclear Material - plutonium, uranium enriched in the isotope 233 or in the isotope 235, and any other material which the Commission, pursuant to the provisions of section 51 [42 U.S.C.2071]m determines to be special nuclear material, but does not include source materia];... [Atomic Energy Act of 1954, Sec.11(aa)].

Spent Nuclear Fuel - fuel that has been withdrawn from a nuclear reactor following irradiation, the constituent elements of which have not been separated by reprocessing... [Nuclear Waste Policy Act, Sec. 2.(23)].

8. SNF storage space will be maintained to provide for recovery and repair of damaged SNF storage facilities and/or vautts.

9. ICPP SNF interim storage facilities retirement dates are forecasted as follows: IFSF--December 2014, CPP-749--December 2014, and CPP$651-$ - to be determined.

SNF SPECIFIC - -

10. The INEL wi11 use a combination of wet and dry storage for INEL SNF.

11. Dry storage can be safely demonstrated for high enriched uranium SNF.

12. Corrosion and leak detection capability can be provided for dry 
storage.

13. The empty storage space in the Irradiated Fuel Storage Facility (IFSF) at ICPP is available to expedite the consolidation program.

14. Improvement to the existing IFSF structural seismic resistance and ventilation system (non-redundancy) will provide acceptable risks (hardening improvements and HVAC upgrades will be economically feasible).

15. SNF from Fort St. Vrain, West Valley, foreign sources, DOE research and development universities, and the Integral Fast Reactor shutdown are not included in INEL SNF consolidation plan. However, a small amount of foreign research and development fuel could be received.

16. SNF storage facilities that cannot be reasonably upgraded to meet current design criteria will be retired in a manner that minimizes safety risk and cost.

17. Aging INEL SNF storage facilities will be replaced via a standardized dry storage system that is recognized and accepted by the public.

18. The potential use of newer, retired INEL SNF/SNM storage facilities to support the national SNF storage program will not be eliminated by this SNF consolidation plan (e.g., PBF, NMIS).

19. Stabilization and future decontamination and decommissioning of emptied SNF storage facilities are not included in this plan.

20. Security requirements wi11 be modified to support the current ICPP SNF management mission.

SNM SPECIFIC --

21. The Uranium-233 at the Radioactive Waste Management Complex is not included in present SNF consolidation planning.

22. The PARKA SNM in IFSF at ICPP will be transferred to Oak Ridge Y-12.

23. The existing ATR and Engineering Test Reactor SNM shipping containers (boxes) wil1 be used for SNM transfers from TRA-621 to CPP-65I with Department of Transportation certification renewal.

24. A ventilation system is not needed for the CPP-651 North Vault for high enriched uranium storage.

25. Surplus TRA security alarms and TRA-621 equipment for ATR SNM receiving inspection will be relocated to ICPP. 
Appendix D

SCHEDULES AND COST ACCOUNT PLANS

TABLE OF CONTENTS

Cost Account Planning-Package Work Statements:

CWBS

No.

Title

No.

A01 PBF Canal SNF Transfer to ICPP IFSF .......... . D-2

A02 TRA ARMF/CFRMF SNF Transfer to ICPP IFSF ........

A03 TRA MTR Canal SNF Characterization, Repackaging and Transfer to ICPP IFSF . . . . . . . . . . . . . D-4

A04. TRA NMIS SNM Transfer to CPP-651.......... D-5

A05 TAN TMI SNF Transfer to New Facility at ICPP ........ D-6

A06 TAN LOFT SNF Packaging and Transfer to CPP-749 ....... D-7

A07 TAN Commercial SNF Packaging and Transfer to ICPP . . . . . . D-8

B01 CPP-603 SNF Repackaging and Transfer to CPP-666 ....... D-9

B02 Rover Bed Material Repackaging and Transfer to CPP-749 . . . . . D-10

B03 Fermi and Peach Bottom SNF Repackaging and Transfer ...... D-11

B04 Follow-On Transfers of Consolidation Fuels . ....... D-12

B05 CPP-603 Fuel Element Cutting Facility (FECF) SNF Transfer to IFSF . . . . . . . . . . D-13

Planning Package Documentation Package Example:

A03 TRA MTR Canal SNF Characterization, Repackaging, and Transfer to ICPP IFSF ..................... . . . . . . . . . . . . . . . .

A031 Shipper Preparations .............. . . . . . . . . .

A032 Receiver Preparations ............ . D-37

A033 Fuel Transfer Operations .............. . . . . . . . . .

A04z Follow Actions............... . . D-115 
CWBS Dictionary: Level 1 (Project) : Level 2 (Cost Acct): Level 3 (Work Pkgs):

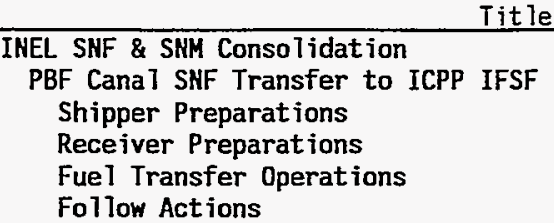

ADS/FWP No: Planning Package Budget and Reporting Classification:

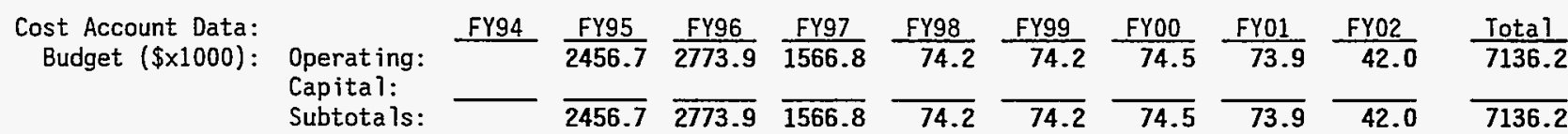

Objectives: Transfer the SNF in the PBF Canal to ICPP IFSF and conduct a dry-storage-demonstration program. Drivers: Perform the work in accordance with all applicable federal regulations.

Program Guidance: E.E. Brolin letter to A.A. Pitrolo, Power Burst Facility (PBF) Management Options, dated January 11. 1994.

Other Documents: A.A. Pitrolo letter to J.C. Okeson, RTD-110-92, dated April 8, 1992.

P. Grumbly letter to Acting Director of Nuclear Energy. NE-1, Transition of the Power Burst Facility, dated Novenber 8, 1993.

D.L. Hamer letter to W.C. Moffitt, OPE-SNF-WJM-93067, Program Execution Guidance for Site Fuel Consolidation, dated December 29, 1993.

Scope of Work: Provide services and equipment for; (a) transfer of the SNF stored in the PBF Canal in building PER-620 to the IFSF dry storage facility at ICPP for interim storage of the fuel assemblies, and (b) conduct of a dry storage demonstration program. A summary description of the SNF. storage facilities, and transfer equipment is as follows:

SNF/SNM Inventory: Uranium Thorium U-233 U-235 Plutonm Source Fission Hvy-Hetal Weapon Classification Oxide $\begin{array}{lcccccc}\text { Weight }(\mathrm{kg}): & 560 & 102.8 & 457.2 & 102.8 & 560 & \text { low enriched uranium }\end{array}$ c SNF/SNM Encapsulation: $\frac{\text { Cladding }}{\text { Material Retentive Robust }} \frac{\text { Canning }}{\text { Material Retentive Robust }} \frac{\text { Fuel-Handling-Unit (FHU) Data }}{\text { Length Cross-Section Weight Units }}$ $304 \mathrm{~L} \mathrm{SS}$ Yes $\frac{\text { Yes }}{\mathrm{NA}} \mathrm{NA} \frac{\mathrm{NA}}{121 \mathrm{~cm}} \frac{\mathrm{Cr}}{1.9 \mathrm{~cm} \mathrm{dia} .} \frac{4.9 \mathrm{~kg}}{2425}$

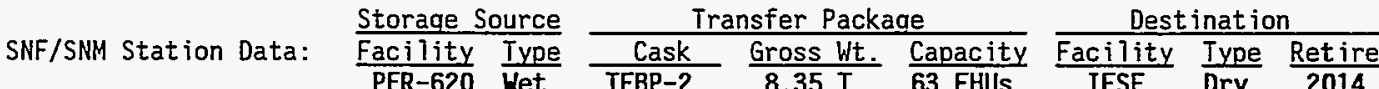

Prerequisites/Assumptions:

NEPA Compliance: Environmental Check Tists will be sufficient for shipper (PER-620) and transfer (TFBP-2) operations. Ho documentation is needed for the receiving (ICPP-IFSF) operations.

DOT Compliance: SNF transfers will comply with the INEL Transportation Safety Manual.

QA Compliance: Quality Level: 1

Readiness Review Type: Formal Review with DOE Oversight ORR for shipper (PER-620) and transfer (TFBP-2) operations. Assessments for receiving (ICPP-IFSF) operations will be sufficient because a formal ORR with DOE oversight will have already been accomplished for the restart of the ICPP drystorage facilities (ICPP-IFSF and CPP-749).

1. The IFSF transfer cart adapter design and construction program cormences July 1, 1994 and is completed June 26, 1995. (See WBS DO7)

2. The Shipper's Project Plan is developed in FY94.

Description

Deliverables: All SHF discharged from PBF Canal 2425 FHUs from PBF installed in IFSF vault racks. Decontaminated TFBP-2 Cask to equipment poo 1

Milestones: Cormence Shipper/Receiver preparations Commence 1st transfer to ICPP Complete dry-storage-demonstration program

Target Date

April 7, 1997 Aprit 9,1997 April 24, 1997

October 3, 1994 March 25, 1996 April 24, 2002 
CWBS Dictionary: Level 1 (Project) : Level 2 (Cost Acct): Level 3 (Work Pkgs):

\begin{tabular}{c} 
Number \\
\hline NA \\
A02 \\
A021 \\
A022 \\
A023 \\
A024
\end{tabular}

\author{
Title \\ INEL SNF \& SNH Consolidation \\ TRA ARHF/CFRMF SHF Transfer to ICPP IFSF \\ Shipper Preparations \\ Receiver Preparations \\ Fuel Transfer Operations \\ Follow Actions
}

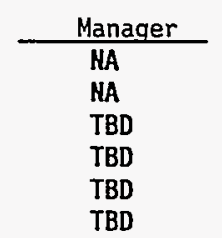

ADS/FWP No: Planning Package Budget and Reporting Classification:

Cost Account Data: Budget $(\$ \times 1000)$ :

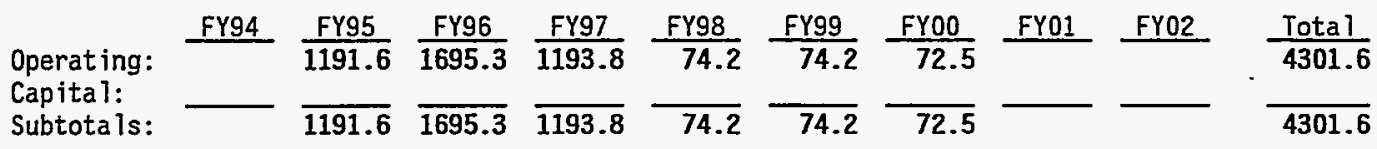

Objectives: Transfer the SNF in the ARMF/CFRHF Canal to ICPP IFSF and TRA-632, Hot Ce11 $\$ 2$. Conduct a dry-storage-demonstration program in ICPP-IFSF.

Perform the work in accordance with all applicable federal regulations.

Drivers:

Program Guidance: None

Other Documents: D.L. Hamer letter to W.C. Moffitt, OPE-SHF-WJM-93067, Pragram Execution Guidance for Site Fuel Consolidation, dated Decenber 29, 1993.

Scope of Work: Provide services and equipment for; (a) transfer of the SHF stored in the ARMF/CRFMF Canal in building TRA-660 to; the IFSF dry storage facility at ICPP for interim storage of the Mark I, II \& III fuel assemblies, and to the Hot Cel1 $\$ 2$ facility in bui\}ding TRA-632 for disassembly of the Core Filter, and (b) conduct of a dry-storagedemonstration program in ICPP-IFSF. A sumary description of the SNF, storage facilities, and transfer equipment is as follows:

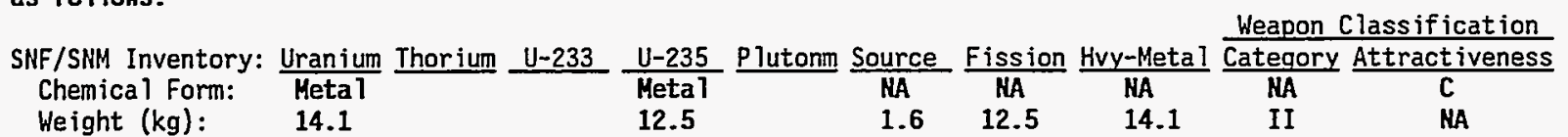

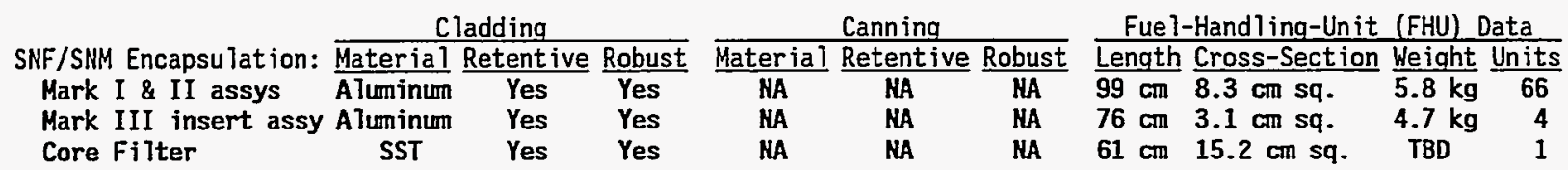

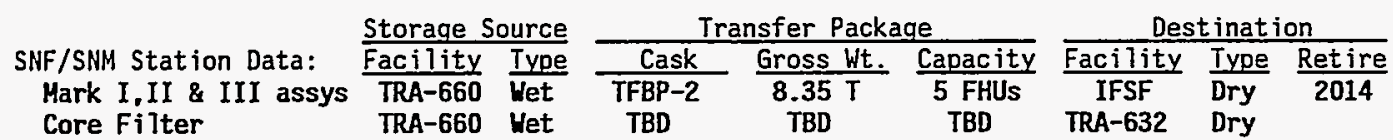

Prerequisites/Assumptions:

NEPA Compliance: Checklists will be sufficient for shipper (TRA-660 \& TRA-632) and transfer (TFBP-2) operations. No documentation is needed for Receiver operations because this is a Phase-in-a-ContinuingActivity.

DOT Compliance: SNF transfers will comply with the IMEL Transportation Safety Manual.

QA Compliance: Quality Leve1: 1

Readiness Review Type: A formal ORR is needed for shipper actions. Assessments will be sufficient for the TFBP-2 transfer and ICPP IFSF.

1. The Shipper's Project Plan and Fuel Characterization report is completed in FY94.

Description

Deliverables: 70 FHUs from ARMF/CFRMF installed in IFSF vault racks A11 SMF discharged from ARHF/CFRMF Canal Decontaminated TFBP-2 Cask to equipment pool

Milestones: Commence Shipper preparations Cormence 1st transfer to ICPP Transfer Core Filter to MTR canal Complete dry-storage-demonstration program
Target Date

September 5, 1997 September 10, 1997 September 19, 1997

October 3, 1994 May 2, 1997

September 10, 1997

September 20, 2000

Consolidation Task Team Report 


$\begin{array}{cc}\text { CWBS Dictionary: } & \text { Number } \\ \text { Level } 1 \text { (Project) }: & \text { NA } \\ \text { Level } 2 \text { (Cost Acct): } & \text { A03 } \\ \text { Level } 3 \text { (Work Pkgs): } & \text { A031 } \\ & \text { A032 } \\ & \text { A033 } \\ & \text { A034 }\end{array}$

ADS/FWP No: Planning Package
Cost Account Data: Budget $(\$ \times 1000)$ :

Operating: Capital: Subtotais:

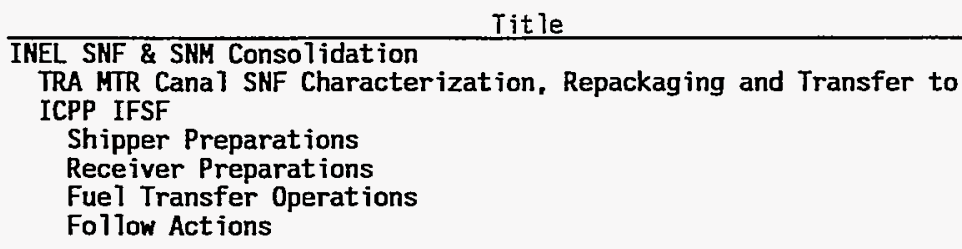

Follow Actions

Budget and Reporting Classification:

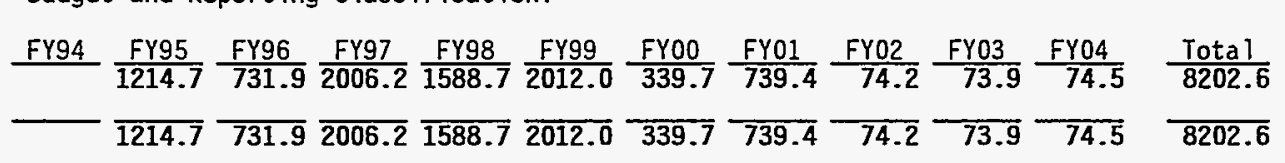

Objectives: Transfer the SNF in the MTR-657 Plug Storage area and the MTR canal to ICPP IFSF.

Conduct a dry-storage-demonstration program.

Drivers:

Perform the work in accordance with all applicable federal regulations.

Program Guidance: None

Other Documents: Buckland, R.J. et al, 1993, INEL D\&D Lonq-Ranqe P lan, EG8G-WH-10924, October 1993.

USDOE, 1994, Plan of Action to Resolve Spent Huclear Fuel Vulnerabilities, Phase $i_{\text {; }}$ Volume 1 Executive Sumary and Volume II. February 1994.

Scope of Work: Provide services and equipment for, (a) characterization, repackaging, and transfer of the SNF stored in the Plug Storage area of Building TRA-657 and the MTR canal in Building TRA-603 to the ICPP IFSF for interim storage with an intermediate stop at Hot Cell $\neq 2$ in Building TRA-632 for recanning, and (b) conduct of a dry-storagedemonstration program. A sumary description of the SNF, storage facilities, and transfer equipment is as follows:

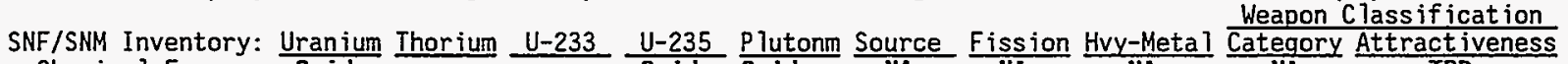

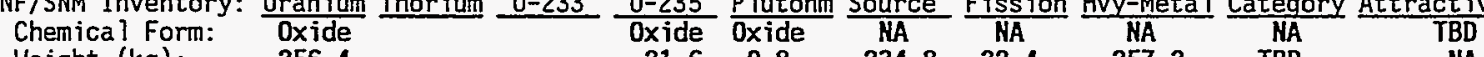

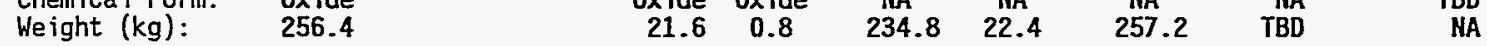

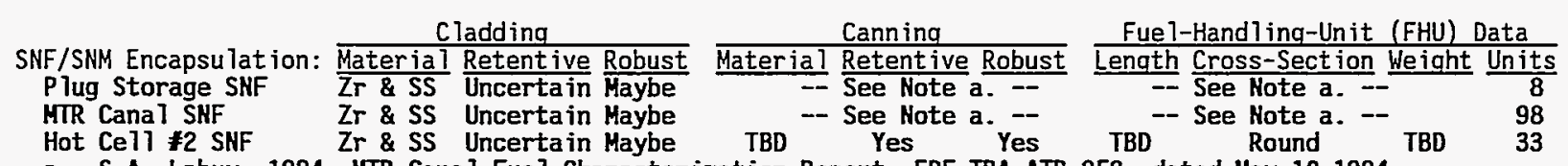
a. S.A. Labuy, 1994, MTR Canal Fuel Characterization Report, EDF-TRA-ATR-958, dated May 10,1994

\begin{tabular}{|c|c|c|c|c|c|c|c|c|}
\hline \multirow[b]{2}{*}{$\begin{array}{l}\text { SNF/SNM Station Data: } \\
\text { Plug Storage SNF } \\
\text { MTR Cana } 7 \text { SNF } \\
\text { Hot Cell } \neq 2 \text { SNF }\end{array}$} & \multicolumn{2}{|c|}{ Storage Source } & \multicolumn{3}{|c|}{ Transfer Package } & \multicolumn{3}{|c|}{ Destination } \\
\hline & $\begin{array}{l}\text { Facility } \\
\text { TRA-657 } \\
\text { TRA-603 } \\
\text { TRA-632 }\end{array}$ & $\begin{array}{l}\frac{\text { Type }}{\text { Dry }} \\
\text { Wet } \\
\text { Dry }\end{array}$ & $\begin{array}{l}\text { Cask } \\
\text { Wh.ET.f2 } \\
\text { Wh.E1.f2 } \\
\text { TFBP-2 }\end{array}$ & $\begin{array}{c}\text { Gross Wt. } \\
\text { TBD } \\
\text { TBD } \\
8.35 \mathrm{~T}\end{array}$ & $\begin{array}{l}\frac{\text { Capacity }}{\text { TBD }} \\
\text { TBD } \\
1 \mathrm{FHU}\end{array}$ & $\begin{array}{l}\text { FaciTity } \\
\text { TRA-632 } \\
\text { TRA-632 } \\
\text { IFSF }\end{array}$ & $\begin{array}{l}\text { Type } \\
\text { Dry } \\
\text { Dry } \\
\text { Dry }\end{array}$ & $\begin{array}{l}\frac{\text { Retire }}{\text { TBD }} \\
\text { TBD } \\
2014\end{array}$ \\
\hline
\end{tabular}

Prerequisites/Assumptions:

NEPA Compliance: A checklist will be sufficient for the operations at MTR canal, TRA-632 Hot, and the transfers with the White Elephant $\$ 2$ and TFBP casks.

No documentation is needed for the Receiver operations which are a Phase-in-a-Continuing-Activity.

DOT Compliance: SNF transfers will comply with the INEL Transportation Safety Manual.

QA Compliance: Quality Leve ]: 1

Readiness Review Type: A forma 7 ORR is needed for shipper operations at the MTR canal and the Hot Ce11 $\neq 2$ restart.

Assessments will be sufficient for: operations at TRA-657 Plug Storage, Plug Storage SHF transfer, TFBP-2 transfer, and IFSF receipt.

1. The Shipper's Project Plan and Fuel Characterization report is completed in FY94.

Description

Deliverables: All SHF discharged from the TRA-657 Plug Storage Area All SNF discharged from the TRA-603 MTR-Canal 33 FHUs from TRA-632 Hot Cell $\neq 2$ installed in IFSF vault racks Decontaminated thite-Elephant $\neq 2$ Cask to equipment pool Decontaminated TFBP-2 Cask to equipment pool

Milestones: Commence Shipper preparations Commence 1st transfer from MTR cana 1 to TRA-632 Hot Cell $\# 2$ Commence 1st transfer to ICPP Comp lete dry-storage-demonstration program
Target Date

June 1, 1998

May 10, 1999

November 18, 1999

May 24, 1999

Novenber 26, 1999

October 3. 1994

June 2, 1998

June 23, 1998

Decenber 2, 2004 
CHBS Dictionary: Level 1 (Project) : Level 2 (Cost Acct): Level 3 (Work Pkgs):

\begin{tabular}{ll}
\multicolumn{1}{c}{ Title } & Manager \\
\hline INEL SNF \& SNH Consolidation & NA \\
TRA NMIS-SNM Transfer to CPP-651 & NA \\
Shipper Preparations & TBD \\
Receiver Preparations & TBD \\
Fuel Transfer Operations & TBD
\end{tabular}

ADS/FWP No: Planning Package Budget and Reporting Classification:

Cost Account Data: Budget $(\$ \times 1000)$ : Operating: Capital: Subtotals:

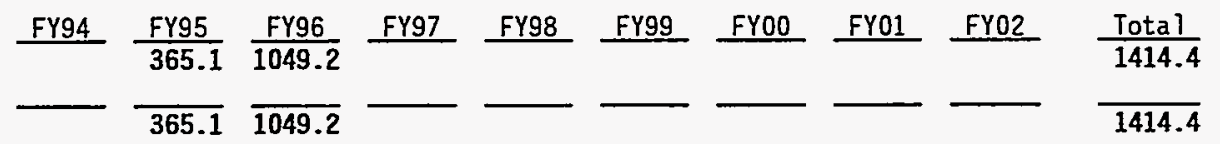

Objectives: Transfer the SNM in the TRA KMIS (TRA-621) facility to CPP-651.

Perform the work in accordance with all applicable federal regulations..

Drivers:

Program Guidance: T.F. Burns, Jr. letter to H.C. Hoffitt and E.N. Fray, AH/OPA-SSD-SMM-94-076, Consolidation of TRA and ICPP Special Nuclear Materials in CPP-651. dated June 201994.

0ther Documents: T.F. Burns, Jr. letter to E.H. Fray and W.C. Moffitt, AM/OPA-SSD-SKM-94-052, Task Team Report Consolidation of TRA and ICPP SpecialiNuclear Materials in CPP-651, dated Apri1 7, 1994. G.E. Dials letter to E.M. Fray and W.C. Moffitt, AM/OPA-SSD-SMM-93-033, Joint E6\&G-UINCO Cost/ Benefit Study - Consolidation of Special Nuclear Materials, dated November 8, 1993.

Scope of Work: Provide services and equipment for transfer of the SHM stored in the TRA NMIS (TRA-621) building to CPP-651 for storage of the fuel assemblies. The TRA fuel element receiving inspection equipment and some security a larm system components will also be transferred to CPP-651. A sumary description of the SNH, storage facilities, and transfer equipment is as follows:

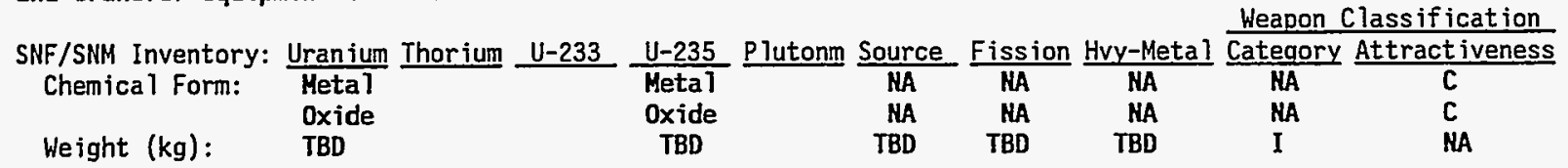

Cladding Canning

SNF/SNM Encapsulation: Material Retentive Robust Material Retentive Robust ATR fuel assemblies Aluminum Yes ETR fuel assemblies Aluminum Yes GETR fuel assemblies TBD Yes PBF fuel rods 304L SS Yes Pellets \& powder NA NA

$\begin{array}{llll}\text { Yes } & \text { HA } & \text { NA } & \text { NA } \\ \text { Yes } & \text { NA } & \text { NA } & \text { NA } \\ \text { Yes } & \text { NA } & \text { NA } & \text { HA } \\ \text { Yes } & \text { NA } & \text { NA } & \text { NA } \\ \text { NA } & \text { TBD } & \text { YES } & \text { YES }\end{array}$

Fue 1-Handling-Unit (FHU) Data Length Cross-Section Weight Units TBD TBD TBD TBD TBD TBD TBD TBD

TBD TBD TBD TBD

$121 \mathrm{~cm} 1.9 \mathrm{~cm} \mathrm{dia.} 4.9 \mathrm{~kg}$ TBD TBD TBD TBD TBD

\section{SNF/SNM Station Data: $\frac{\text { Storage Source }}{\frac{\text { Facility }}{\text { TRA-621 }} \frac{\text { Type }}{\text { Dry }} \frac{\text { Cask }}{\text { ATR \& ETR }} \frac{\text { Gross Wt. }}{\text { TBD }} \frac{\text { Capacity }}{\text { TBD FHUs }} \frac{\text { Destination }}{\text { CPP-651 }} \frac{\text { Type }}{\text { Dry }} \frac{\text { Retire }}{\text { TBD }}}$}

Prerequisites/Assumptions:

NEPA Compliance: Environmental checklists will be sufficient for Receiver operations. No documentation is needed for Shipper or transfer operations.

DOT Compliance: SNM transfers will comply with the INEL Transferation Safety Manual. QA Compliance: Quality Level: 1

Readiness Review Type: An ORR or RA is not planned for the TRA HMIS packaging for transfer operations or the transfer operations. An RA will be performed for the Receiver (CPP-651) operations.

Description

Deliverables: ATR security system components installed and S0-tested at ICPP. ATR fuel receiving inspection station installed and SO-tested at CPP-651 All SHM discharged from ATR NHIS facility TBD FHUs from ATR NMIS facility installed in CPP-651 vault racks.

Milestones: Commence Receiver CSE/SAR preparation Cormence 1st transfer to ICPP

Target Date

TBD

TBD

July 2, 1996

JuTy 3, 1996

January 6, 1995

March 26, 1996 


$\begin{array}{ll}\text { CWBS Dictionary: } & \frac{\text { Number }}{\text { NA }} \\ \text { Leve } 1 \text { (Project) : } & \text { A05 } \\ \text { Level } 2 \text { (Cost Acct): } & \text { A051 } \\ \text { Level } 3 \text { (Work Pkgs): } & \text { A052 } \\ & \text { A053 } \\ & \text { A054 } \\ & \text { A055 }\end{array}$

ADS/FWP No: Planning Package
INEL SNF \& SNM Consolidation

Title

TAN TMI-SNF Transfer to New Facility at ICPP

Shipper Preparations

Receiver Preparations

Fuel Transfer Operations

Follow Actions

Storage Facility Construction
Manaqer

C.D. Roberts

TBD

TBD

TBD

TBD

TBD

Cost Account Data:

Budget $(\$ \times 1000)$ :

Budget and Reporting Classification:

Operating:

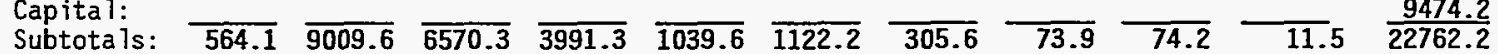

Objectives: Transfer the TMI-2 SNF (core debris) in the TAN-607 Storage Pool to a new dry storage facility at CPP-749. Conduct a dry-storage-demonstration program in CPP-749.

Drivers:

Perform the work in accordance with all applicable federal regulations.

Program Guidance: Action Description Memorandum for Dry Cask Storage Project approved on May $26,1993$.

Other Documents: D.L. Hamer letter to W.C. Hoffitt. OPE-SNF-WJM-93067. Program Execution Guidance for Site Fuel Consolidation, dated December 29, 1993.

USDOE, 1994, Plan of Action to Resolve Spent Nuclear Fuel Vulnerabilities, Phase 1; Volume 1

Executive Summary and VoTume II. February 1994.

Scope of Work: Provide services, facilities, and equipment for; (a) transfer of the TMI-2 SNF stored in the TAN-607 Storage Pool to a new facility at CPP-749, and (b) conduct of a dry-storage-demonstration program. A summary description of the SNF, storage facilities, and transfer equipment is as follows:

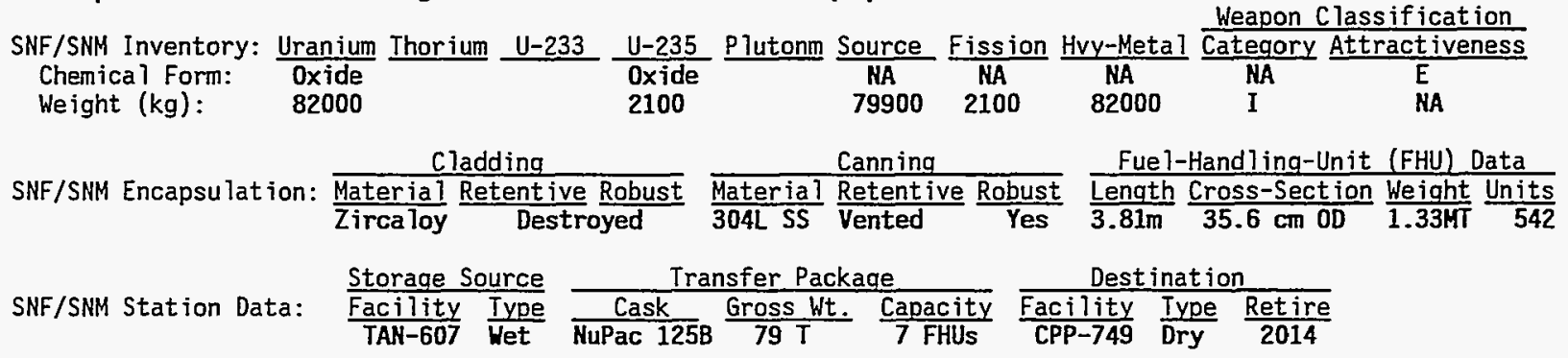

Prerequisites/Assumptions:

NEPA Compliance: An Enviromental Assessment is needed for the new equipment (canister dryer) acquisition and the storage facility construction.

Enviromental check lists will be prepared for shipping and receiving operations, which are phases in a cont inuing activity.

DOT Compliance: SNF transfers will comply with the INEL Transportation Safety Manual.

QA Compliance: Quality Level: 1

Readiness Review Type: Formal Review with DOE Oversight ORR will be needed for; the Shipper (TAN-607) operations, and the new dry-storage facility at ICPP.

An Assessment may be sufficient for the NuPac 125B transfers.

1. The Cost Account will be extensively revised when DOE approves the revised Draft Environmental Assessment for the TAN Pool Stabilization Project which proposes an above-grade, monolithic, horizontal-vault, storage facility

instead of the grade-level pad with modular, vertical-vault, transfer-\&-storage, casks.

2. The LOFT and Commercial SNF has been removed from the TAN-607 Storage Pool.

Description

Deliverables: All SNF discharged from TAN-607 Storage Pool

542 FHUs from TAN installed in new dry storage facility at CPP-749

Decontaminated NuPac 125B Cask returned to equipment poo?

Mi lestones:

Resume Title I design of interim storage facility at CPP-749 DOE approve revised Draft Envirommenta] Assessment docunent Comence construction of interim storage facility at CPP-749 Commence 1st THI-2 SNF transfer to ICPP

Complete dry-storage-demonstration progran at ICPP

\section{Target Date}

November 9, 1999 November 17,1999 December 17, 1999

Decenber 15, 1994 April 6, 1995 August 24, 1995 November 4, 1997

November 26, 2002 
CWBS Dictionary:

Level 1 (Project):

Level 2 (Cost Acct):

Level 3 (Work Pkgs):

\begin{tabular}{l} 
Number \\
\hline NA \\
A06 \\
A061 \\
A062 \\
A063 \\
A064
\end{tabular}

INEL SNF \& SNM Consolidation
TAN LOFT-SHF Packaging \& Transfer to ICPP
Shipper Preparations
Receiver Preparations
Fuel Transfer Operations
Follow Actions

\begin{tabular}{l} 
Manager \\
\hline NA \\
NA \\
TBD \\
TBD \\
TBD \\
TBD
\end{tabular}

ADS/FWP No: Planning Package Budget and Reporting Classification:

\begin{tabular}{|c|c|c|c|c|c|c|c|c|c|c|c|c|}
\hline $\begin{array}{l}\text { Cost Account Data: } \\
\text { Budget }(\$ \times 1000) \text { : }\end{array}$ & Oper & FY94 & $\frac{F Y 95}{616.2}$ & $\frac{F Y 96}{1156.8}$ & $\frac{F Y 97}{423.8}$ & $\frac{\text { FY98 }}{138.4}$ & $\frac{\text { FY99 }}{74.2}$ & $\frac{F Y O O}{74.5}$ & $\frac{\mathrm{FY} 01}{73.9}$ & $\frac{\mathrm{FYO2}}{74.2}$ & $\frac{\mathrm{FYO3}}{46.9}$ & $\frac{\text { Tota } 1}{2679.0}$ \\
\hline
\end{tabular}

Objectives: Transfer the LOFT SNF in the TAN-607 Storage Pool to ICPP. Conduct a dry-storage-demonstration program in CPP-749.

Perform the work in accordance with a 11 applicable federal regulations.

Drivers:

Program Guidance: Action Description Memorandum for Dry Cask Storage Project approved on May $26,1993$.

Other Documents: D.L. Hamer Tetter to W.C. Hoffitt. OPE-SNF-WJM-93067, Program Execution Guidance for Site Fuel Consolidation, dated Decenber 29, 1993.

USDOE, 1994, Plan of Action to Resolve Spent Nuclear Fuel Vulnerabilities, Phase 1; Volume 1

Executive Summary and Volume II. February 1994.

Scope of Work: Provide services and equipnent for; (a) packaging and transfer of the LOFT SNF stored in the TAN-607

Storage Pool to a ICPP dry storage (CPP-749 or IFSF), and (b) conduct of a dry-storage-demonstration program in CPP-

749. A sumary description of the SNF, storage facilities, and transfer equipment is as follows: SNF/SNM Inventory: Uranium Thorium
$\begin{aligned} & \text { Chemical Form: } \\ & \text { Weight }(\mathrm{kg}):\end{aligned} \quad 2204$

Cladding

SNF/SNM Encapsulation: Material Retentive Robust Material Retentive Robust $A 1, A 2, A 3$ \& F1 assys Zircaloy Likely $\frac{\text { Yes }}{\text { Likly }}$ Control \& FP-1 assys Zircaloy Possible Maybe Corner assembijies FP-2 debris Zircaloy Probable Maybe Zircaloy Destroyed

Storage Source

SNF/SNM Station Data: Facility Type Intact assemblies $\frac{\text { TAN-607 Vet }}{\text { TARl-607 }}$ FP-2 debris $\begin{array}{ll}\text { TAN-607 } & \text { Yet } \\ \text { TAN-607 } & \text { Wet }\end{array}$

\begin{tabular}{|c|c|c|}
\hline Cask & Gross Wt & Capacity \\
\hline $\begin{array}{l}\text { PeachBtm } \neq 2 \\
\text { PeachBtm } \neq 2\end{array}$ & $\begin{array}{l}34.5 \mathrm{~T} \\
34.5 \mathrm{~T}\end{array}$ & $\begin{array}{ll}2-4 & \text { FHUs } \\
2-4 & \text { FHUS }\end{array}$ \\
\hline
\end{tabular}

Fue l-Handling-Unit (FHU) Data Length Cross-Section Weight Units

TBD $22 \mathrm{~cm} \mathrm{sq}$ TBD 4 TBD $22 \mathrm{~cm} \mathrm{sq.} \mathrm{TBD}$

TBD $\quad 19.3 \mathrm{~cm}-\mathrm{leg} \wedge \quad$ TBD TBD TBD TBD TBD

Destination Facility Type Retire CPP-749 Dry 2014 CPP-IFSF Dry 2014

Prerequisites/Assumptions:

NEPA Compliance: Environmental checklists will be prepared for shipper, shipping, and receiving operations, which are phases in a continuing activity.

DOT Compliance: SNF transfers will comply with the IHEL Transportation Safety Manual.

QA Compliance: Quality Level: 1

Readiness Review Type: An ORR will be needed for the shipper (TAN-607) and transfer operations. An RA will be sufficient for receiver operations.

Description

Deliverables: 13 LOFT-SNF FHUs from TAN installed in CPP-749 vaults FP-2 debris from TAN installed in CPP-IFSF

Decontaminated PeachBottom $₹ 2$ Cask returned to equipment pool

Milestones: Commence Shipper preparations

Commence 1st LOFT-SNF transfer to ICPP

Complete dry-storage-demonstration program at ICPP
Target Date

January 17, 1997

May 6, 1998

May 20, 1998

October 3, 1994

December 3, 1996

May 20, 2003 
CWBS Dictionary: Level 1 (Project) : Level 2 (Cost Acct):

Leve 13 (Work Pkgs):

\begin{tabular}{c} 
Number \\
\hline HA \\
$A 07$ \\
$A 071$ \\
$A 072$ \\
$A 073$ \\
$A 074$ \\
$A 075$
\end{tabular}

Title
INEL SNF \& SNM Consolidation
TAN Commercial SNF Transfer to CPP-749

Shipper Preparations

Receiver Preparations

Fuel Transfer Operations

Follow Actions

Storage Pad Construction
TBD

TBD

TBD

TBD

TBD

ADS/FWP No: Planning Package

Budget and Reporting Classification:

Cost Account Data:

Budget $(\$ \times 1000)$ : Operating:

Capital:

Subtotals:

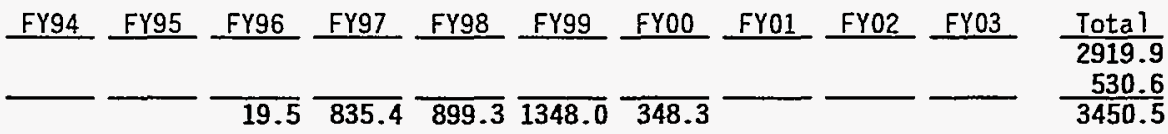

Objectives: Transfer the Cormercial-SNF at TAN to CPP-749.

Perform the work in accordance with all applicable federal regulations.

Drivers:

Program Guidance: None

Other Documents: D.L. Hamer letter to W.C. Moffitt, OPE-SNF-WJM-93067, Program Execution Guidance for Site Fuel

Consolidation, dated December 29, 1993.

USDOE, 1994, Plan of Action to Resolve Spent Nuclear Fuel Vulnerabilities, Phase 1; Volume 1

Execut ive Summary and Volume II. February 1994.

Scope of Work: Provide services, facility, and equipment for transfer of the DOE-owned, Commercial-SNF stored at TAN to CPP-749. The Conmercial-SNF is stored in the TAN-607 Storage Pool in aluminum coffins and in four dry-storagecasks on a concrete pad (TAN-791) outside the TAN-607 Hot Shop. A summary description of the SNF. storage facilities, and transfer equipment is as follows:

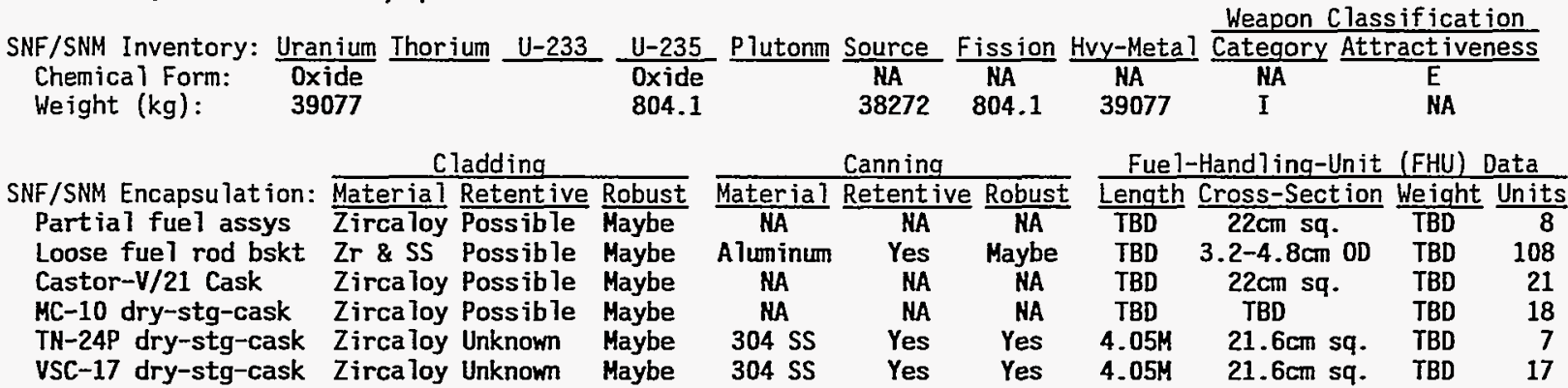

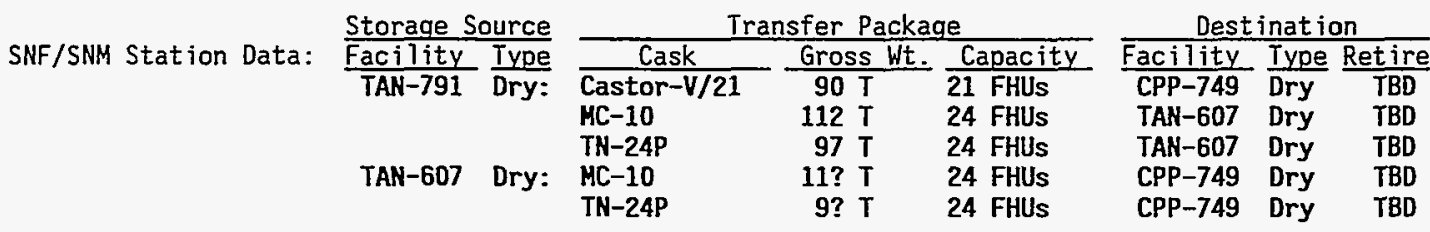

Prerequisites/Assumptions:

NEPA Compliance: Environmental checklists will be prepared for shipper, shipping, and receiving operations which are phases in a continuing activity.

DOT Compliance: SNF transfers will comply with the INEL Transportation Safety Manual.

QA Compliance: Quality Level: 1

Readiness Review Type: Assessments will be sufficient for shipper and transfer operations. An ORR with DOE oversight is needed for receiver operations.

1. The 6 partially-disassembled BUR and PWR fuel assemblies and the loose fuel rod pieces encapsulated in 108 tubes in Loose Fuel Rod Storage Basket are transferred to the TAN-607 Silo in FY-1994.

2. There is sufficient space available in the MC-10 and TN-24P casks for all the Commercial SNF at TAN.

Description

Deliverables: SNF removed from the VSC-17 Cask

A11 SNF removed from TAN-791 (concrete pad outside TAN-607 Hot Shop) Commercial-SNF from TAN transferred to CPP-749

Milestones: Commence Shipper preparations (DOT exemption application) Commence construction of dry-storage-cask pad at CPP-749 Cormence 1st Commercial-SNF transfer to ICPP

\section{Target Date}

December 27, 1999

January 13,2000

January 24, 2000

October 3, 1995

June 3, 1998

December 30, 1999 
CWBS Dictionary: Level 1 (Project) : Leve 2 (Cost Acct): Number

Level 3 (Work Pkgs):

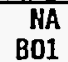

$\mathrm{B013}$
INEL SNF \& SNH Consolidation
CPP-603 SHF Repackaging and Transfer to CPP-666
Receiver Preparations
Fuel Transfer Operations
Title

\begin{tabular}{l} 
Manager \\
\hline HA \\
NA \\
TBD \\
TBD
\end{tabular}

ADS/FWP No: 1010.02/ Budget and Reporting Classification:

Cost Account Data Budget $(\$ \times 1000)$ :

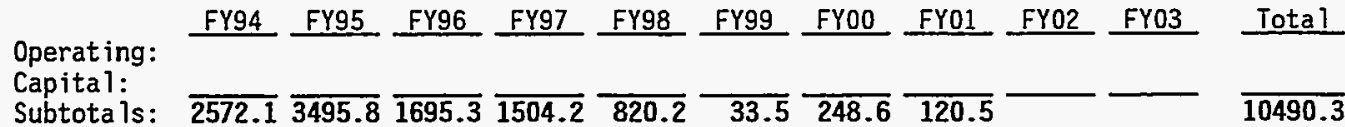

Objectives: Discharge al1 SNF from the CPP-603 wet-storage basins. Perform the work in accordance with all applicable federal regulations.

Drivers:

Program Guidance: TBD

Other Documents: H.L. Ryan (Sr. U.S. District Judge) Order Modifying Order of June 28, 1993, dated September 20, 1993.

Scope of Work: Provide services, facilities, and equipment for repackaging as needed and transfer of the SNF stored in the three (North, Middle \& South) CPP-603 wet storage basins to CPP-666. A summary description of the SNF, storage facilities, and transfer equipment is as follows:

Weapon Classification

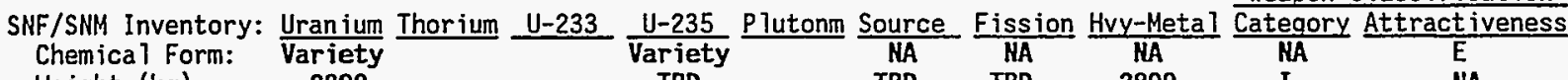
$\begin{array}{llllllll}\text { Weight }(\mathrm{kg}): & 2899 & \text { TBD } & \text { TBD } & \text { TBD } & 2899 & \text { I } & \text { HA }\end{array}$

Cladding Canning

Fue l-Handling-Unit (FHU) Data SNF/SNM Encapsulation: Material Retentive Robust Material Retentive Robust Lenqth Cross-Section Weight Units See Note a Variety $\frac{\text { Mixture }}{\text { Mix }}$ Variety $\frac{\text { Mixture Mix }}{\text {-- See Note a -- }}$ a. SHF-5800-450-004. Spent Fuel Background Report Predecisional Draft Volume II. EG\&G Idaho, February 1994.

\begin{tabular}{|c|c|c|c|c|}
\hline & Storage Source & & Isfer Package & Destination \\
\hline SNF/SNM Station Data: & $\frac{\text { Facility }}{\text { CPP-603 Type }}$ & $\frac{\text { Cask }}{\text { STR Charger }}$ & $\frac{\text { Gross Wt. }}{<15 T} \frac{\text { Capacity }}{\text { TBD }}$ & $\frac{\text { Facility }}{\text { CPP-666 }} \frac{\text { Type }}{\text { Wet }} \frac{\text { Retire }}{\text { TBD }}$ \\
\hline
\end{tabular}

Prerequisites/Assumpt ions: NEPA Compliance: Appropriate documentation has been subnitted and approved. DOT Compliance: SHF transfers will comply with the INEL Transportation Safety Manual. QA Compliance: Quality Leve1: 1 Readiness Review Type: The ORR has been completed.

Description

Deliverables: SNF removed from CPP-603 wet storage basins

Milestones: Commence 1st SNF transfer (Fuel Transfer $\$ 5$ ) to CPP-666
Target Date

December 31, 2000

March 1, 1994 
CWBS Dictionary: Level 1 (Project): Level 2 (Cost Acct)

\begin{tabular}{l} 
Number \\
\hline NA \\
B02 \\
B022 \\
B023 \\
B024
\end{tabular}

\begin{tabular}{lll}
\multicolumn{1}{c}{ Title } & & Manager \\
\hline INEL SNF \& SNM Consolidation & & NA \\
Rover-Bed Material Repackaging and Transfer to CPP-749 & & NA \\
Receiver Preparations & & TBD \\
Fuel Transfer Operations & TBD \\
Follow Actions & TBD
\end{tabular}

ADS/FWP No: Planning Package

Budget and Reporting Classification:
Cost Account Data: Budget $(\$ \times 1000)$ :

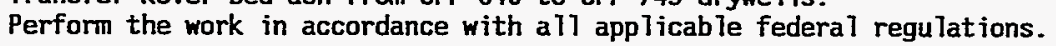

Perform the work in accordance with all applicable federal regulations.

Objectives: Transfer Rover-Bed ash from CPP-640 to CPP-749 drywe 1ls.

Drivers:

Program Guidance: TBD

Other Documents: EG\&G-WM-10924, INEL D\&D Long-Range P lan, EG\&G Idaho, October 1993.

Scope of Work: Provide services, facilities, and equipment for; (a) receipt and packaging-for-storage of the Rover Bed ash from CPP-640 in ICPP-IFSF, and (b) transfer of the Rover-Bed SNF to CPP-749 drywe1ls. A summary description of the SNF, storage facilities, and transfer equipment is as follows:

SNF/SNM Inventory: Uranium Thorium U-233 U-235 Plutonm Source Fission Hvy-Metal $\frac{\text { Weapon Class if icat ion }}{\text { Category Attractiveness }}$ Chemical Form: $\frac{\text { Oxide }}{\text { Oxide }} \frac{\text { Dxide }}{\text { NA }} \frac{\text { NA }}{\text { NA }} \frac{\text { Category Attractive }}{\text { NA }}$

$\begin{array}{lllllll}\text { Weight }(\mathrm{kg}): & \text { TBD } & \text { TBD } & \text { TBD } & \text { TBD } & \text { TBD } & \text { TBD }\end{array}$

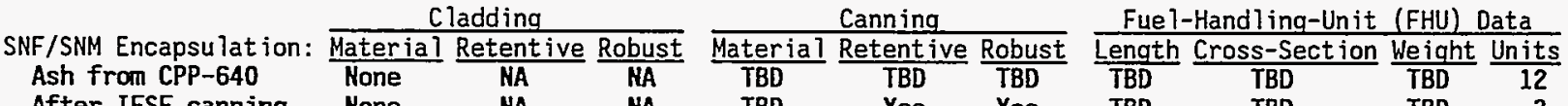

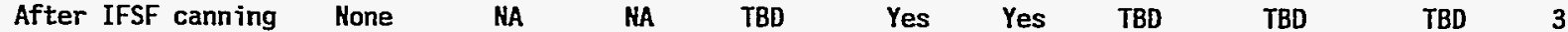

\begin{tabular}{|c|c|c|c|c|c|c|}
\hline \multirow[b]{2}{*}{ SNF/SNM Station Data: } & Storage Source & \multicolumn{3}{|c|}{ Transfer Package } & \multicolumn{2}{|c|}{ Destination } \\
\hline & $\begin{array}{l}\frac{\text { Facility }}{\text { CPP-640 }} \frac{\text { Type }}{\text { Dry }} \\
\text { ICPP-IFSF Dry }\end{array}$ & $\begin{array}{l}\text { Cask } \\
\text { Rover Tr.Cask } \\
\text { PeachBtm } 2\end{array}$ & $\begin{array}{l}\text { Gross Wt. } \\
\text { TBD } \\
34.5 T\end{array}$ & $\begin{array}{l}\text { Capacity } \\
\text { TBD } \\
\text { TBD }\end{array}$ & $\begin{array}{l}\text { Facility } \\
\text { ICPP-IFSF } \\
\text { CPP-749 }\end{array}$ & $\begin{array}{l}\text { Type } \frac{\text { Retire }}{2014} \\
\text { Dry } \\
\text { Dry } \\
2014\end{array}$ \\
\hline
\end{tabular}

Prerequisites/Assumptions:

NEPA Compliance: Environmental checklists will be sufficient for the IFSF. Peach-Bottom f2 transfers, and CPP-749 actions.

DOT Compliance: SNF transfers will comply with the INEL Transportation Safety Manual.

QA Compliance: Quality Leve 1: 1

Readiness Review Type: Readiness assessments will be sufficient for the IFSF, Peach-Bottom $¥ 2$ transfers and CPP-749 activities.

1. A new dry-canning station is operational in ICPP-IFSF.

2. An ORR has been successfully completed for restart of ICPP SNF dry-storage facilities (IFSF \& CPP-749).

\begin{tabular}{lll} 
& \multicolumn{1}{c}{ Description } & Target Date \\
\cline { 2 - 3 } Deliverables: & $\begin{array}{l}\text { Rover-Bed ash removed from CPP-640 } \\
\text { Rover-Bed ash installed in CPP-749 vaults }\end{array}$ & August 11, 1997 \\
Milestones: & $\begin{array}{l}\text { Commence ICPP-IFSF (receiver) preparation } \\
\text { Commence 1st SNF transfer to ICPP-IFSF }\end{array}$ & $\begin{array}{l}\text { February 28, 1996 } \\
\text { July 17, 1997 }\end{array}$
\end{tabular}


CWBS Dictionary: Level 1 - (Project) : Leve 2 (Cost Acct):

Level 3 (Work Pkgs):

\begin{tabular}{c} 
Number \\
\hline KA \\
B03 \\
B032 \\
B033 \\
B034
\end{tabular}

INEL SNF \& SNH Consolidation FERMI and Peach-Bottom SNF Repackaging and Tranšfers Receiver Preparations Fuel Transfer Operations Facility Haintenance
Manager

MA

NA

TBD

TBD

TBD

ADS/FWP No: Planning Package

Budget and Reporting Classification:

Cost Account Data: Budget $(\$ \times 1000)$ :

Operating: Capita 1: Subtota is

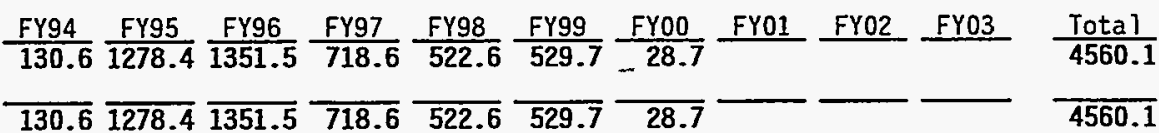

Objectives: Transfer FERHI and Peach-Bottom SNF from ICPP-IFSF 1st-generation drywells to 2nd-generation dry wells. Perform the work in accordance with all applicable federal regulations.

Orivers:

Program Guidance: TBD

Other Documents: U.S. DOE, 1993, Spent Fuel Working Group Report on Inventory and Storage of the Department's Spent Nuclear Fuel and Other Reactor Irradiated Huclear Haterials and Their Environmental, Safety and Hea Tth Vulnerabilities, December 7, 1993.

Scope of Work: Provide services, facilities, and equipment for; (a) transfer of Peach-Bottom SNF from

- CPP-749 1st-generation drywells to ICPP-IFSF for recanning. (b) transfer of the recanned SNF to CPP-749 2ndgeneration drywells, and (c) transfer of FERMI-SNF from ist to 2 nd-generation drywells. A summary description of the SNF, storage facilities, and transfer equipment is as follows:

Weapon Classification

SNF/SNM Inventory: Uranium Thorium U-233 U-235 Plutonm Source Fission Hvy-Metal Category Attractiveness Peach Bottom:

Chemical Form

Carbide

FERHI :

Chemical Form Metal Metal

Weight $(\mathrm{kg})$ : $\quad 1627$
34172

\section{Carbide \\ 123 1513}

Cladding

SNF/SNM Encapsulation: Material Retentive Robust Peach-Bottom SNF FERHI SNF $\begin{array}{lll}\text { Carbon Unlikely No } & \text { SS Possible Maybe }\end{array}$ Material Retentive Robust TBD $\frac{\text { TBD }}{\text { TBD }}$ TBD

NA
34149

NA NA

$114 \quad$ NA
NA

123

NA

35.8

NA

34.2
NA

I
E

NA

E

Fuel-Handling-Unit (FHU) Data Length Cross-Section Weight Units $\frac{166 \mathrm{~cm}}{8.89 \mathrm{~cm} \mathrm{OD}} \frac{\mathrm{kg}}{41 \mathrm{~kg}} \frac{\mathrm{h96}}{796}$ $108 \mathrm{~cm} 8.25 \mathrm{~cm}$ OD $\quad 98 \mathrm{~kg} \quad 510$

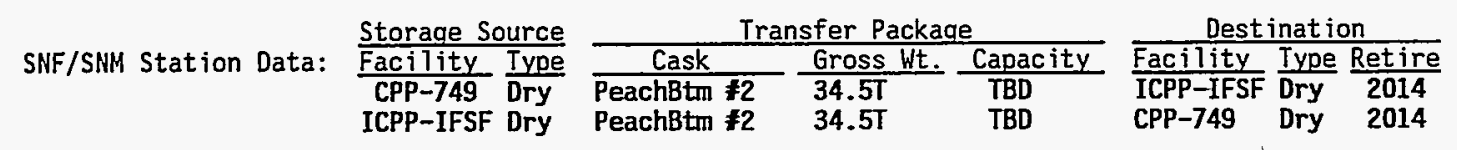

Prerequisites/Assumptions:

MEPA Compliance: Environmental checklists will be sufficient for the IFSF, Peach-Bottom 2 transfers, and CPP-749 actions.

DOT Compliance: SNF transfers will comply with the INEL Transportation Safety Manual.

QA Compliance: Quality Level: 1

Readiness Review Type: An ORR will be performed for this SNF transfer project. .

1. A new dry-canning station is operational in ICPP-IFSF.

Description

Target Date

Deliverables: A11 SHF discharged from CPP-749 1st generation drywe lls FERMI and Peach Bottom SNF installed in CPP-749 2nd-generation drywells

Milestones: Commence ICPP preparation Commence 1st (Peach Bottom) SNF transfer to ICPP-IFSF
August 14, 1997 August 15, 1997

May 1, 1994 October 27, 1995 
CWBS Dictionary:

Level 1 (Project) :

Level 2 (Cost Acct):

Level 3 (Work Pkgs):
Number

NA

BO4

$\mathrm{BO} 42$

B043
INEL SHF \& SNM Consolidation
Follow-on Transfers of Conso

Receiver Preparations

Fuel Transfer Operations
Title

idation Fuels

TBD

ADS/FWP No: Planning Package Budget and Reporting Class ification:

Cost Account Data:

Budget $(\$ \times 1000)$ :

$$
\begin{aligned}
& \text { Operating: } \\
& \text { Capital: } \\
& \text { Subtotals: }
\end{aligned}
$$

Object ives: Transfer the ARHF/CFRMF-SNF from ICPP-IFSF to CPP-749 drywells.

Perform the work in accordance with all applicable federal regulations.

Drivers:

Program Guidance: None.

Other Documents: D.L. Hamer letter to W.C. Hoffitt, OPE-SNF-WJH-93067. Program Execution Guidance for Site Fue1 Consolidation, dated December 29, 1993.

Scope of Work: Provide services and equipment for transferring the ARHF/CFRMF-SNF from ICPP-IFSF to CPP-749. A sumary description of the SNF and storage facilities is as follows:

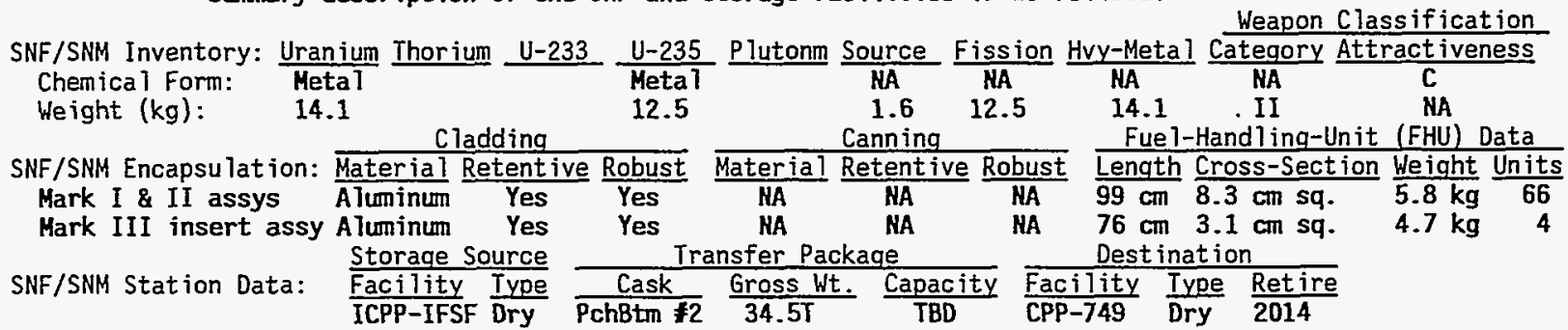

Prerequisites/Assumptions:

NEPA Compliance: Enviromental checklists will be sufficient.

DOT Compliance: Not Applicable

QA Compliance: Quality Leve 1: 1

Readiness Review Type: Assessments will be sufficient for the SNF dry-storage demonstration activities.

Description

Target Date

Deliverables: 70 FHUs from ARMF/CFRMF installed in CPP-749 drywe1ls

Novenber 16, 1999

Milestones:

Commence ICPP preparations

Commence 1st ARMF/CFRMF-SNF transfer to CPP-749 drywel ts

June 23, 1999

October 27,1999 
CWBS Dictionary: Level 1 (Project): Leve 2 (Cost Acct): Level 3 (Work Pkgs):

$\frac{\text { Number }}{\text { NA }}$

INEL SNF \& SNM Consolidation

Title CPP-603 FECF SNF Repackaging and Transfer to IFSF ICPP Preparations

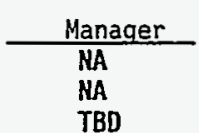

ADS/FWP No: 1010.02/ Budget and Reporting Classification:

Cost Account Data: Budget $(\$ \times 1000)$ :

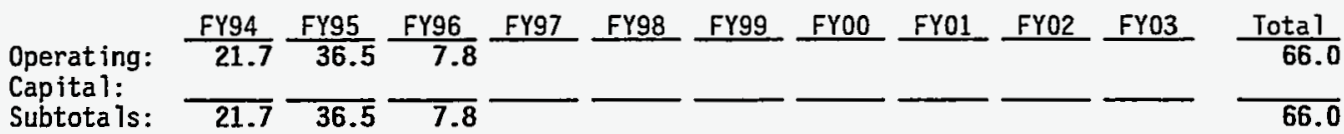

Objectives: Develop plan for discharging a 11 SNF (two Peach Botton units) from the CPP-603 FECF. Perform the work in accordance with all applicable federal regulations.

Drivers:

Program Guidance: TBD

Other Documents: EG\&G-WM-10924, IHEL D\&D Long-Range P lan, EG\&G Idaho, October 1993.

U.S. DOE, 1993, Spent Fuel Horking Group Report on Inventory and Storage of the Department's Spent Huclear Fuel and Other Reactor Irradiated Nuclear Haterials and Their Enviromental, Safety and Health Vulnerabilities, Decenber 7, 1993.

Scope- of Work: Provide services for preparing and verifying the planning for transferring the two Peach Bottom SNF segments from the CPP-603 FECF to ICPP-IFSF for canning and storage. A summary description of the SNF, storage facilities, and transfer equipment is as follows:

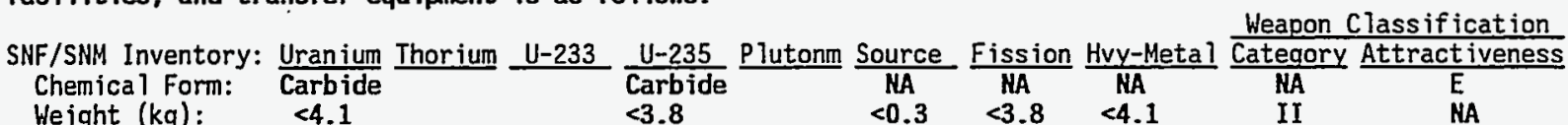

Cladding

SNF/SNM Encapsulation: Material Retentive Robust Material Retentive Robust
Canning None NA $\frac{\text { MA }}{\text { NA }}$
Fuel-Handling-Unit (FHU) Data

Length Cross-Section Weight Units

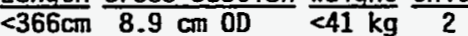

SNF/SNM Station Data: $\frac{\text { Storage Source }}{\text { Facility Type }}$

Transfer Package

Destination

Facility Type $\frac{\text { Cask }}{\text { CPP-603 Gross Wt. Capacity }} \frac{\text { Facility Type Retire }}{34.5 T} \frac{\text { Try }}{\text { TCPD }}$

Prerequisites/Assumptions:

NEPA Compliance: An Environmental Checklist will be sufficient.

DOT Compliance: SNF transfers will comply with the IMEL Transportation Safety Manual.

QA Compliance: Quality Level: 1

Readiness Review Type: An ORR may be performed for restart of operations in CPP-603 FECF.

Description

Tarqet Date

Deliverables: Project Plan for transfer of SHF from CPP-603 FECF to ICPP-IFSF storage basket 0ctober 25,1995

Milestones: Comnence development of Project Plan

May 1, 1994 


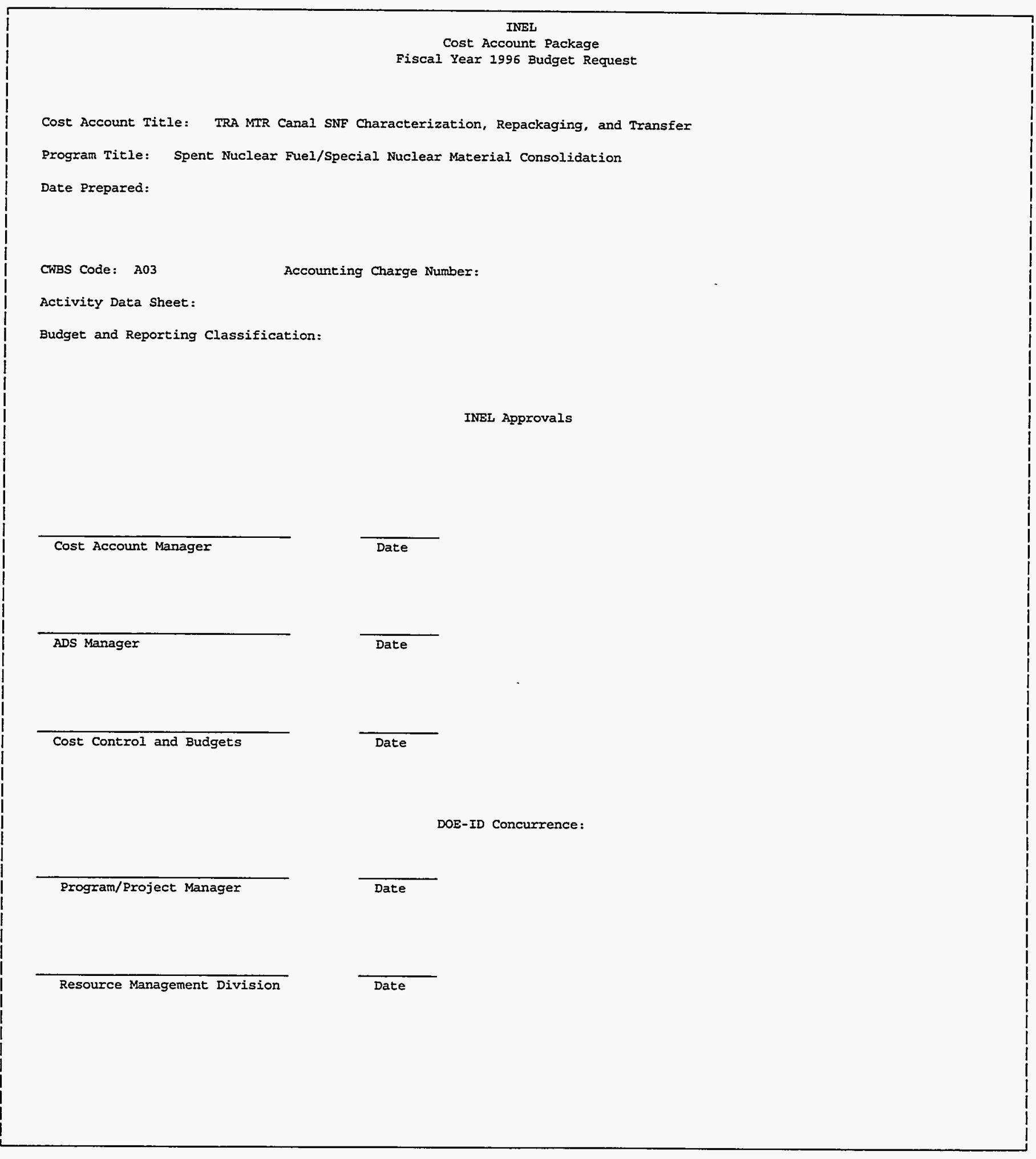

D. 14 


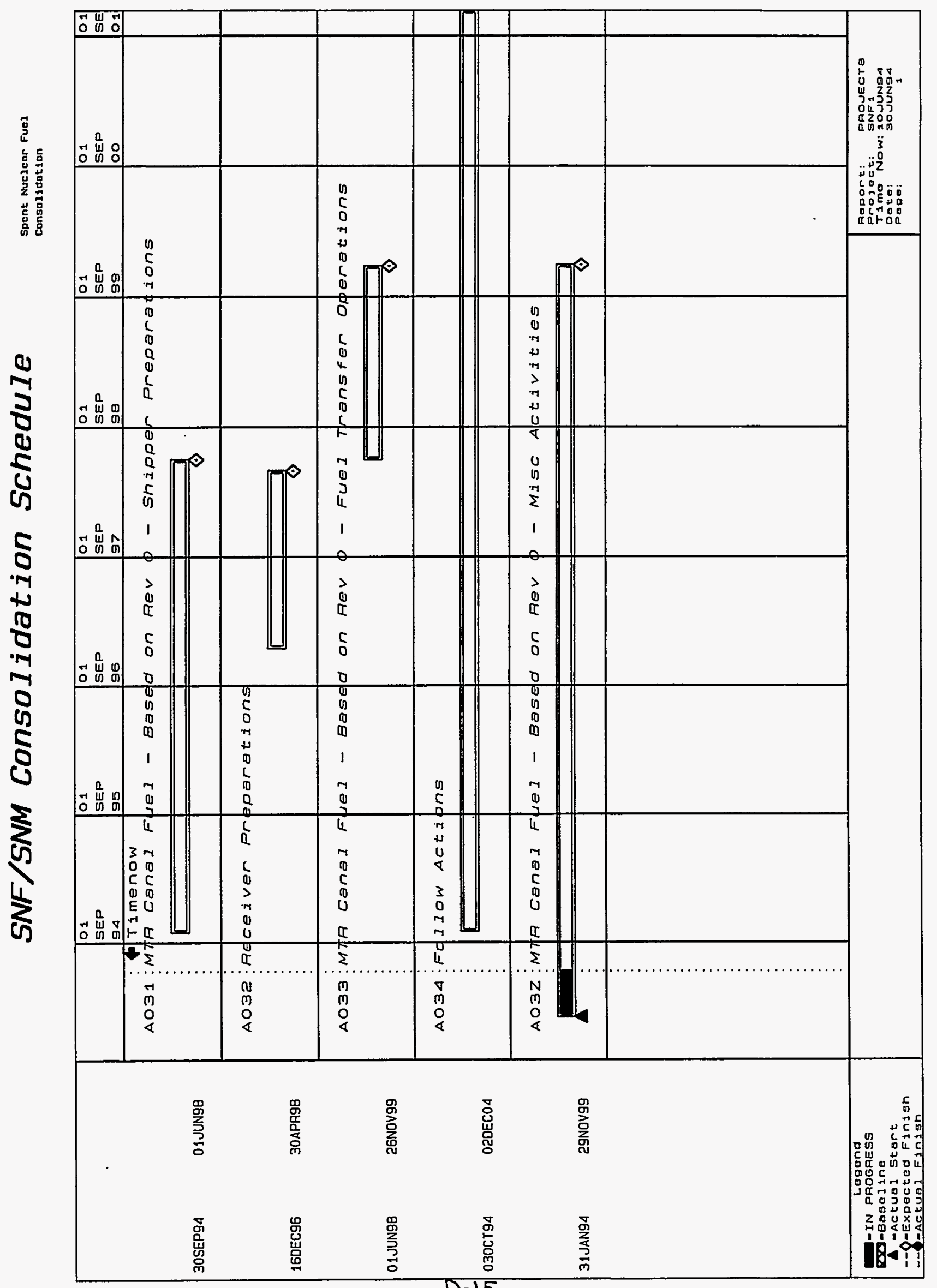

$n-15$ 


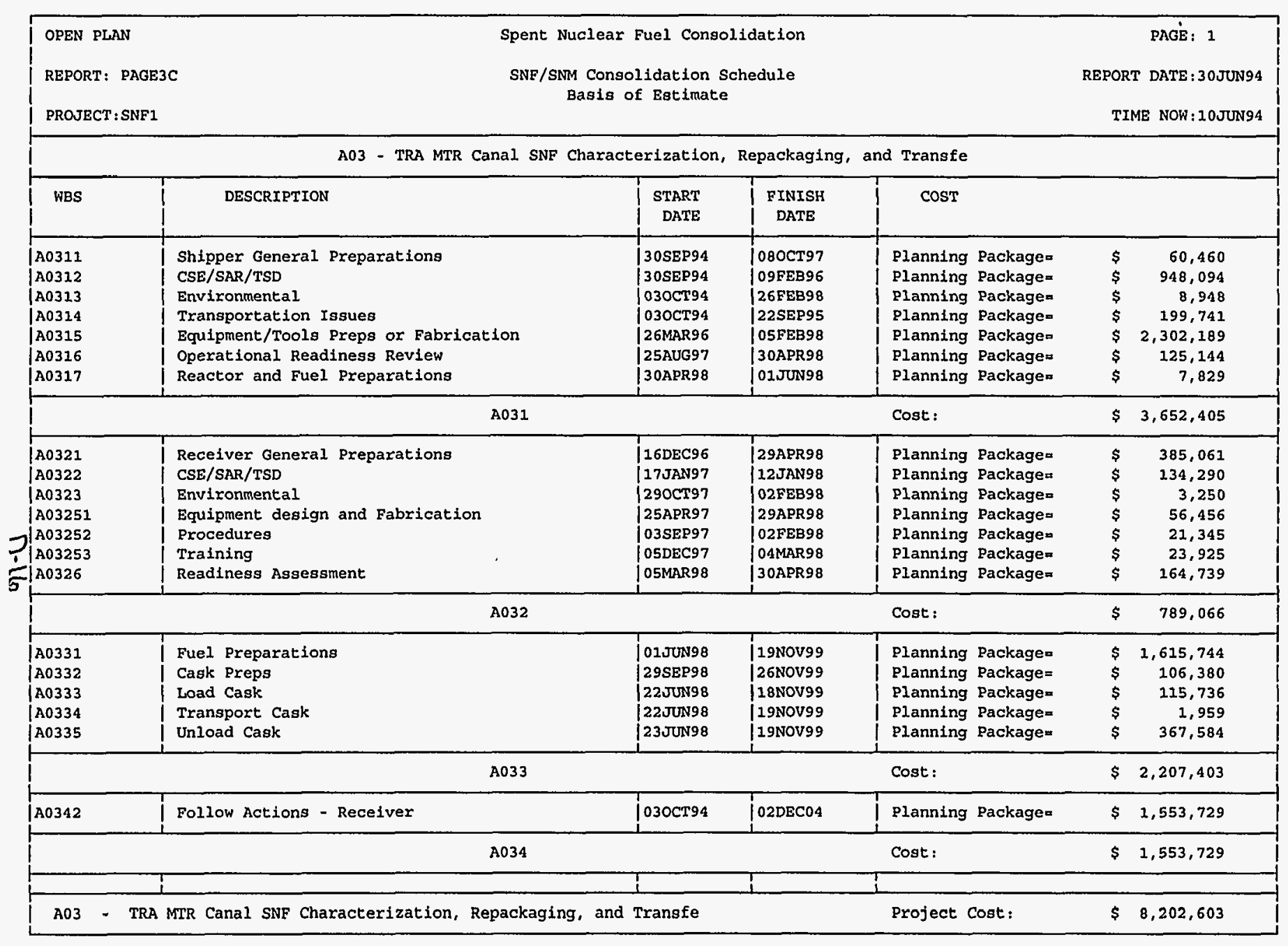




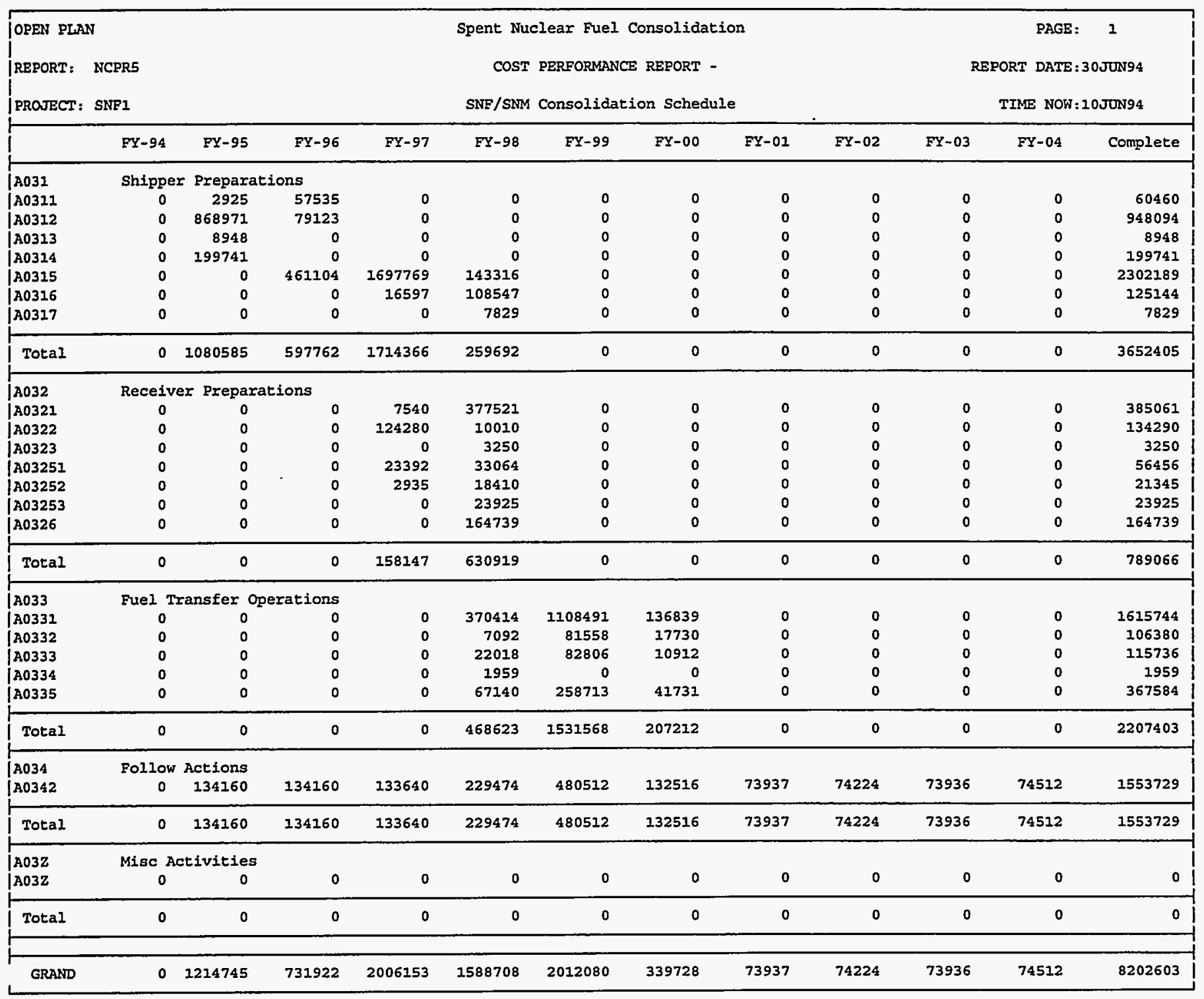




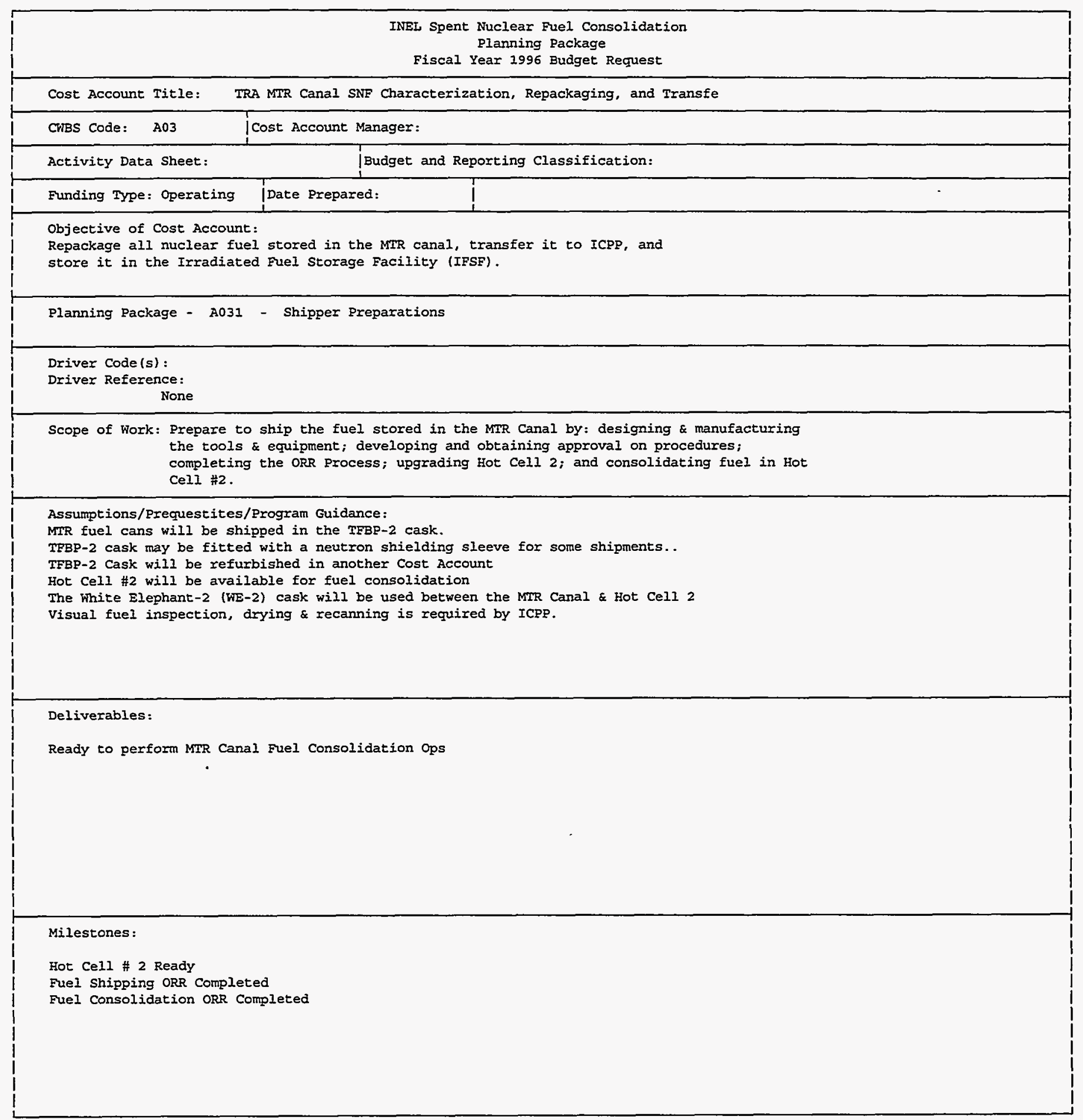




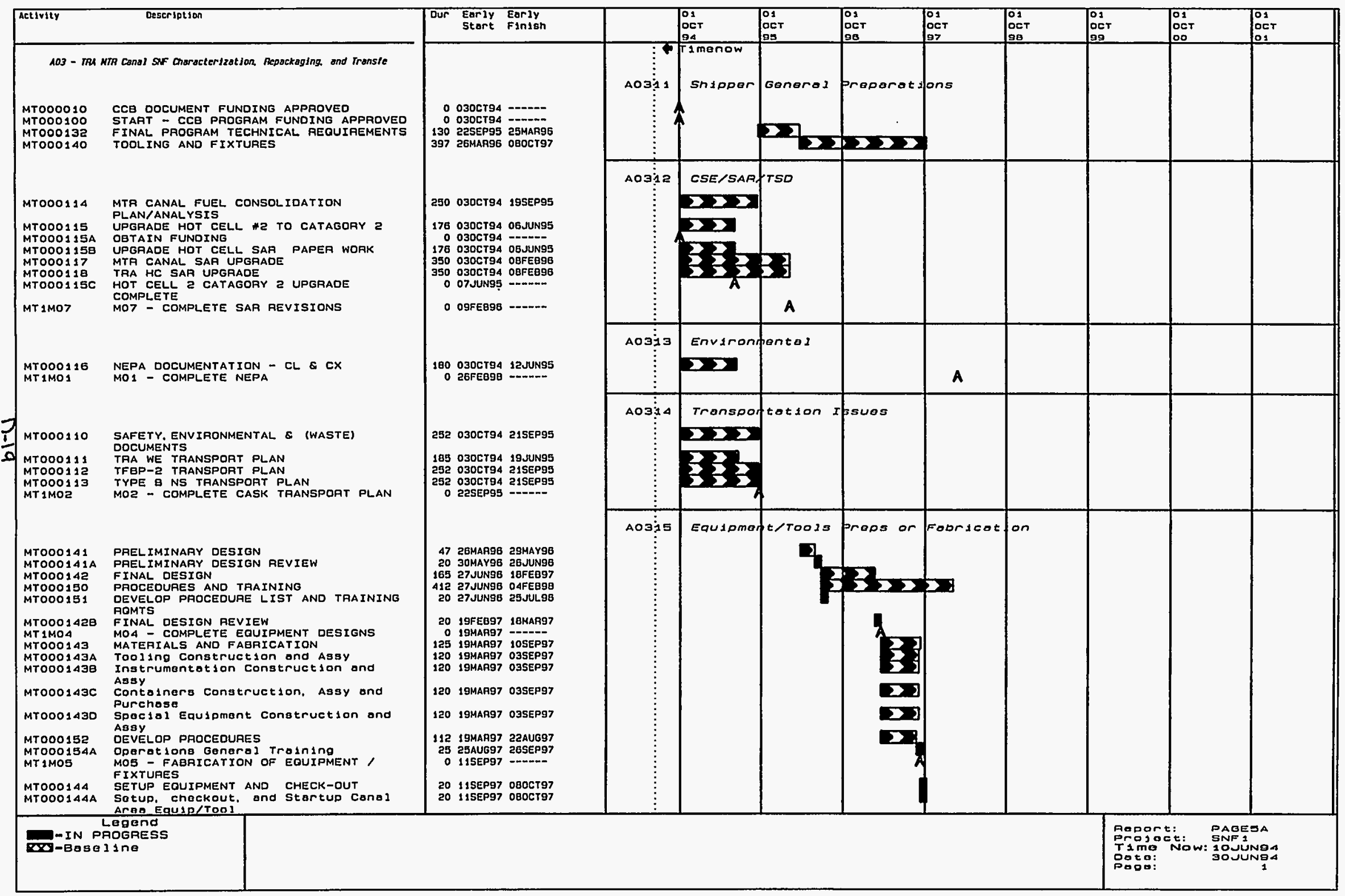




\section{SNF/SNM Consolidation Schedule}

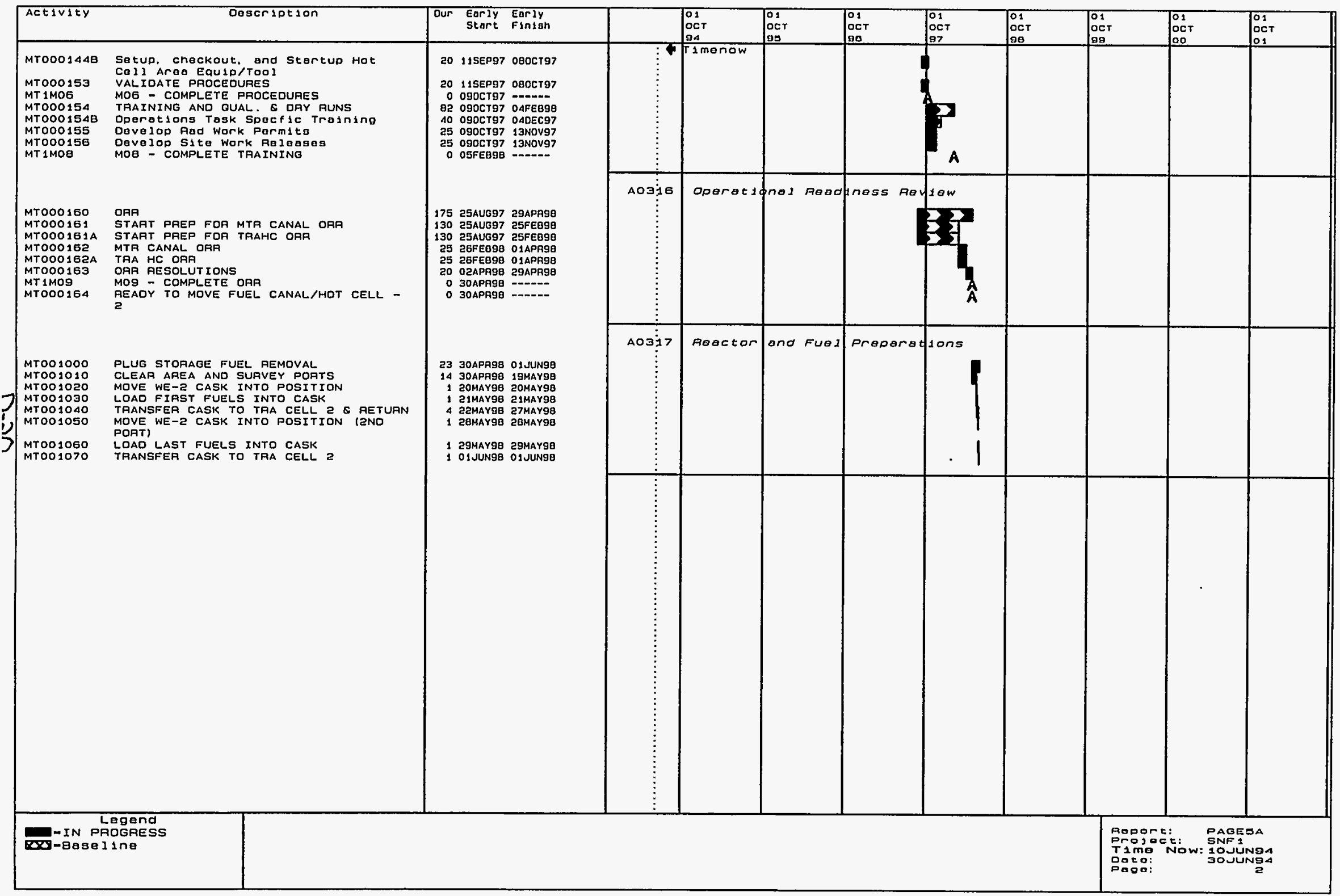




\begin{tabular}{|c|c|c|c|c|c|c|}
\hline $\begin{array}{l}\text { OPEN PLAN } \\
\text { REPORT: PAGE3C } \\
\text { PROJECT: SNF1 }\end{array}$ & \multicolumn{4}{|c|}{$\begin{array}{l}\text { Spent Nuclear Fuel Consolidation } \\
\text { SNF/SNM Consolidation Schedule } \\
\text { Basis of Estimate }\end{array}$} & \multicolumn{2}{|c|}{$\begin{array}{c}\text { PAGE: } 1 \\
: \\
\text { REPORT DATE: } 30 \text { JUN94 } \\
\text { TIME NOW: 10JUN94 }\end{array}$} \\
\hline \multicolumn{7}{|c|}{ A03 - TRA MTR Canal SNF Characterization, Repackaging, and Transfe } \\
\hline WBS & DESCRIPTION & $\begin{array}{r}\text { START } \\
\text { DATE }\end{array}$ & $\begin{array}{c}\text { FINISH } \\
\text { DATE }\end{array}$ & $\cos T$ & & \\
\hline $\begin{array}{l}A 0311 \\
A 0312 \\
A 0313 \\
A 0314 \\
A 0315 \\
A 0316 \\
A 0317\end{array}$ & $\begin{array}{l}\text { Shipper General Preparations } \\
\text { CSE/SAR/TSD } \\
\text { Environmental } \\
\text { Transportation Issues } \\
\text { Equipment/Tools Preps or Fabrication } \\
\text { Operational Readiness Review } \\
\text { Reactor and Fuel Preparations }\end{array}$ & $\begin{array}{l}\text { 30SEP94 } \\
\text { |30SEP94 } \\
\text { |03OCT94 } \\
\text { |030CT94 } \\
\text { |26MAR96 } \\
\text { 25AUG97 } \\
\text { |30APR98 }\end{array}$ & 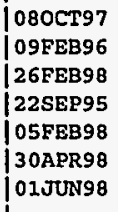 & $\begin{array}{l}\text { Planning Package= } \\
\text { Planning Package= } \\
\text { Planning Package= } \\
\text { Planning Package= } \\
\text { Planning Package= } \\
\text { Planning Package= } \\
\text { Planning Package= }\end{array}$ & $\begin{array}{l}\$ \\
\$ \\
\$ \\
\$ \\
\$ \\
\$ \\
\$\end{array}$ & $\begin{array}{r}60,460 \\
948,094 \\
8,948 \\
199,741 \\
2,302,189 \\
125,144 \\
7,829\end{array}$ \\
\hline \multicolumn{4}{|c|}{ A031 } & Cost: & \multicolumn{2}{|c|}{$\$ 3,652,405$} \\
\hline \multicolumn{4}{|l|}{$\mathrm{A03}-$} & Project Cost: & $\$$ & $3,652,405$ \\
\hline
\end{tabular}

立 


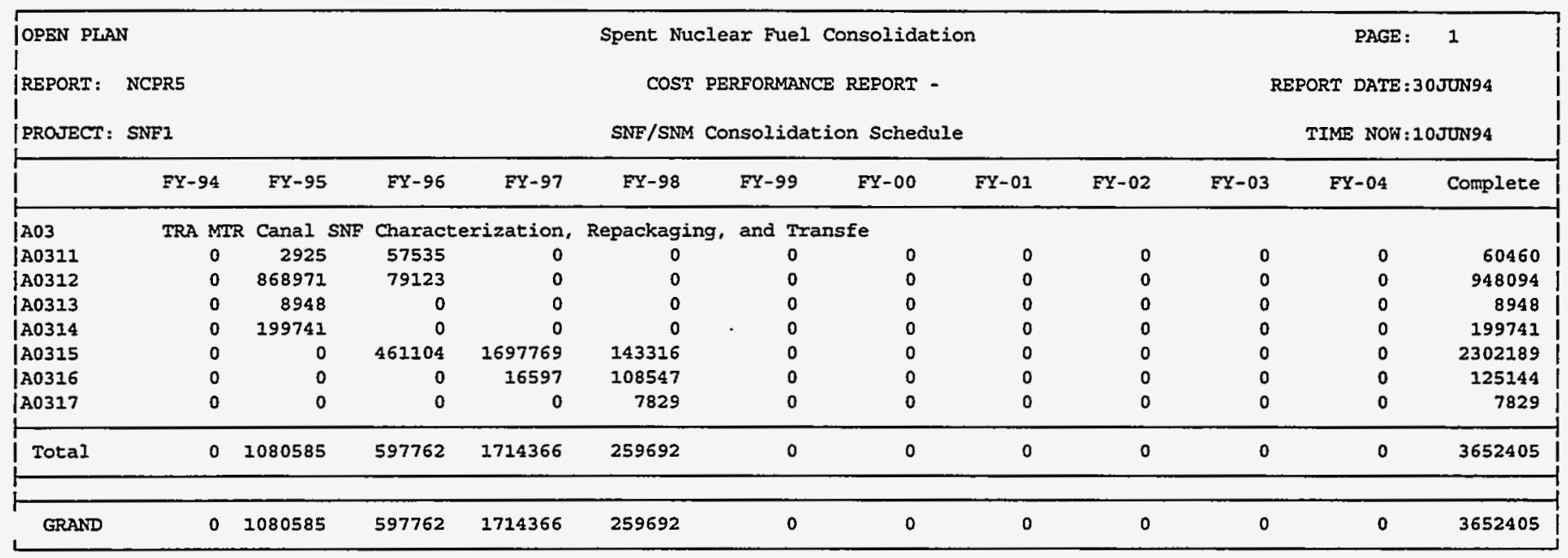




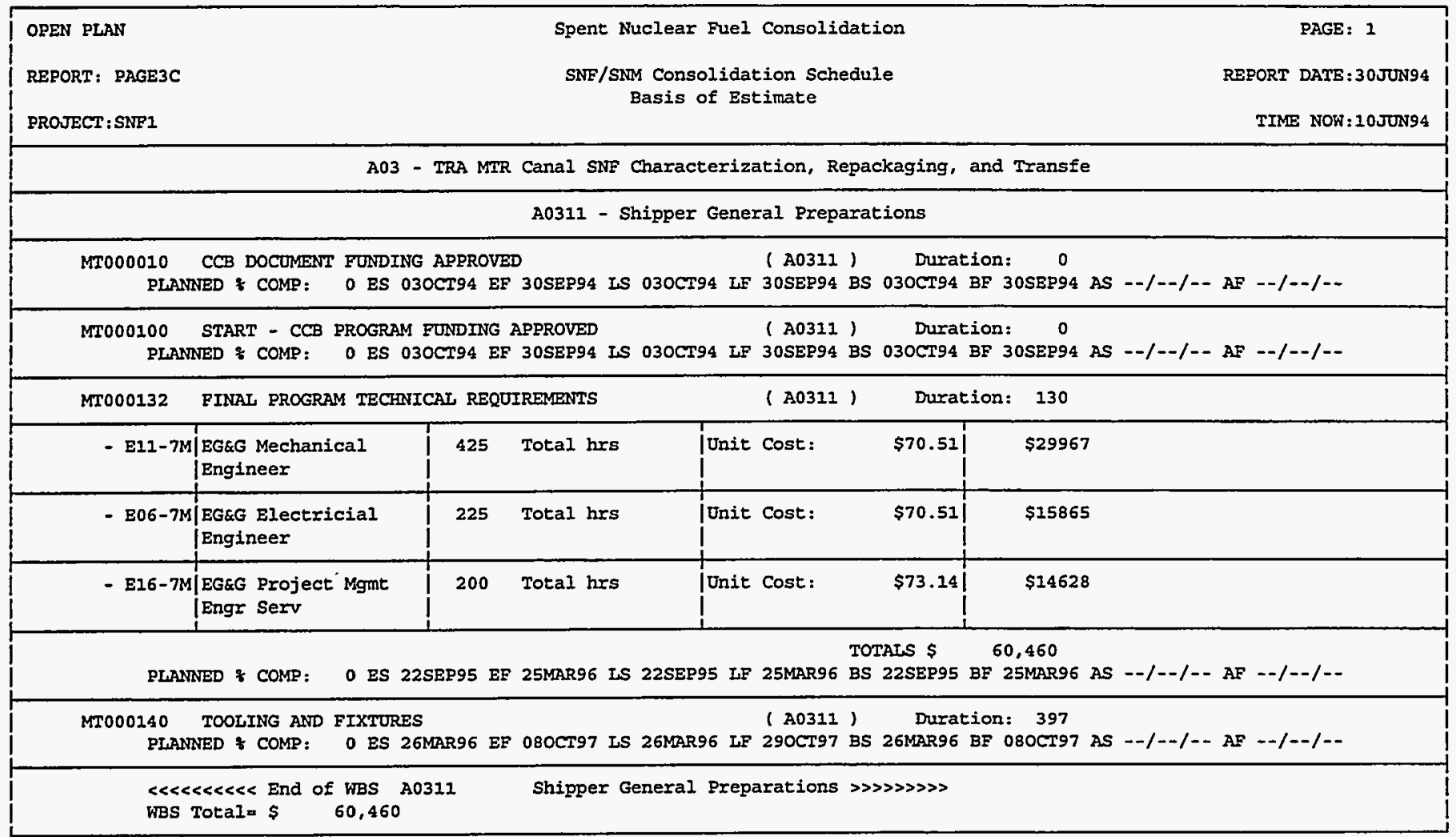

\section{$D-23$}




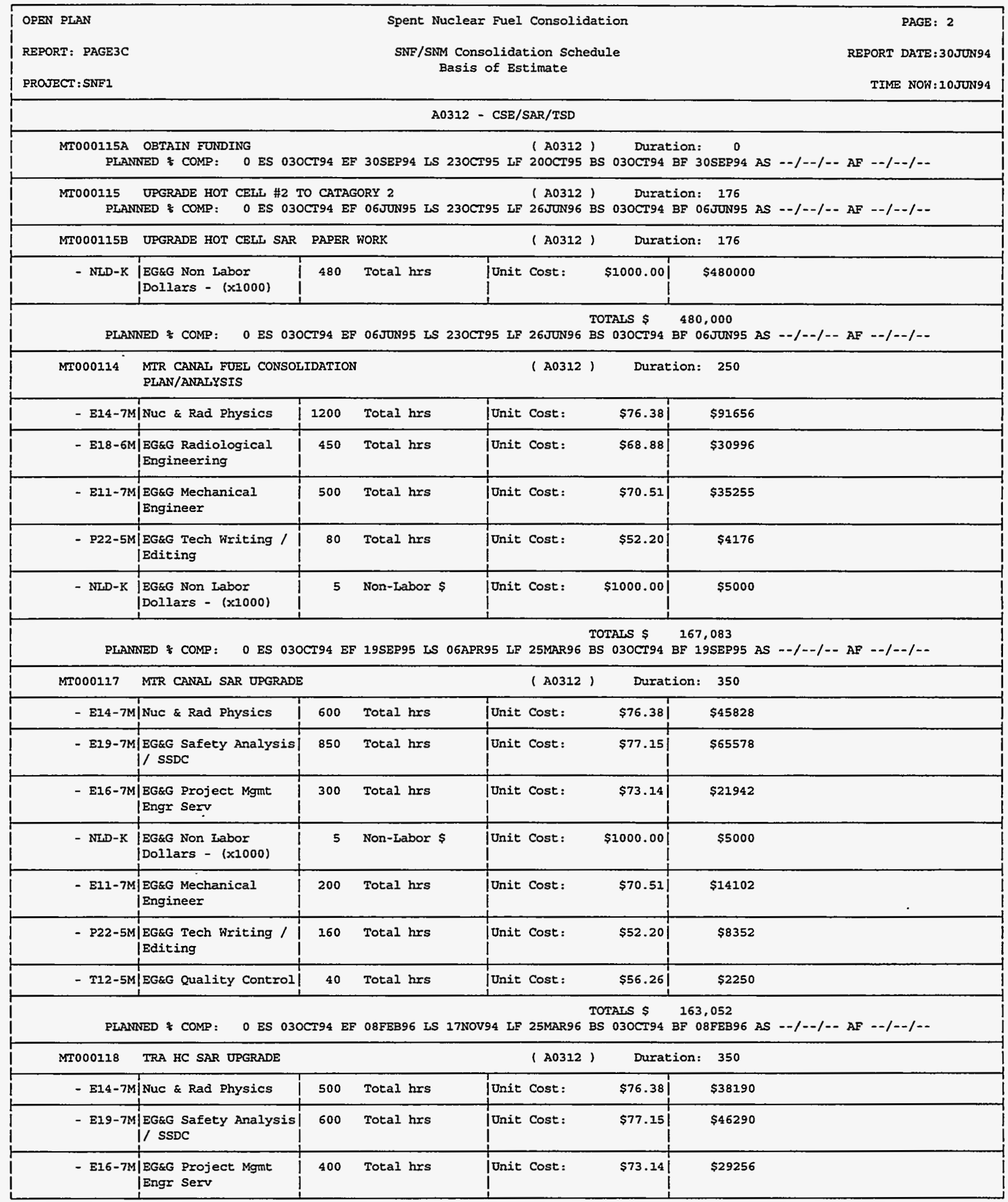




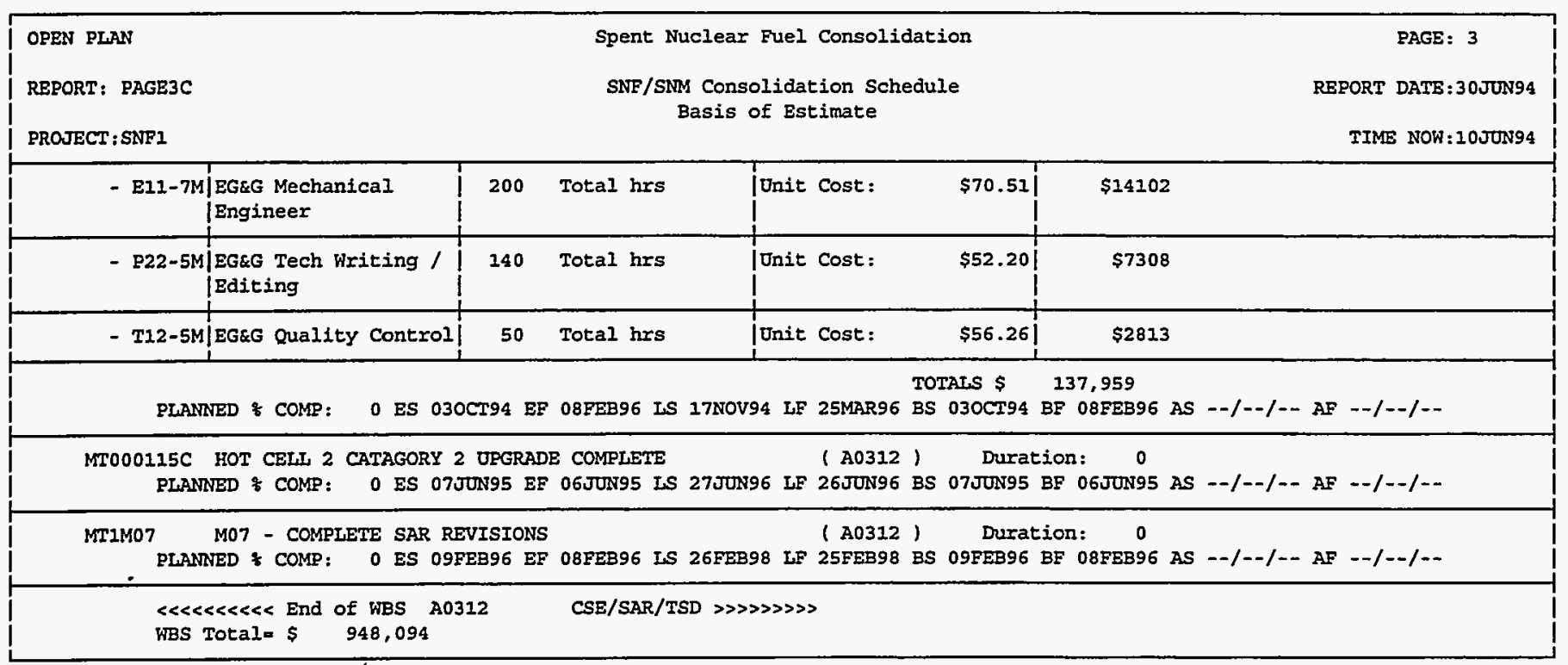




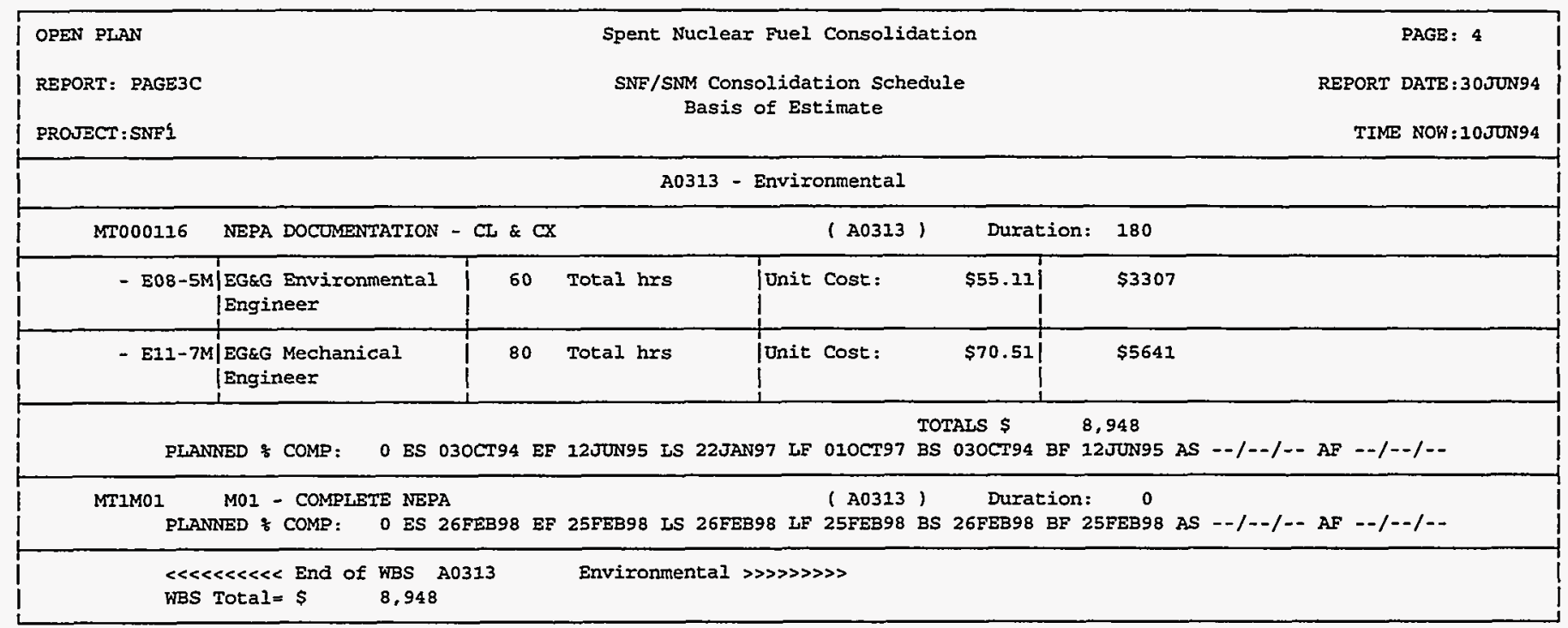




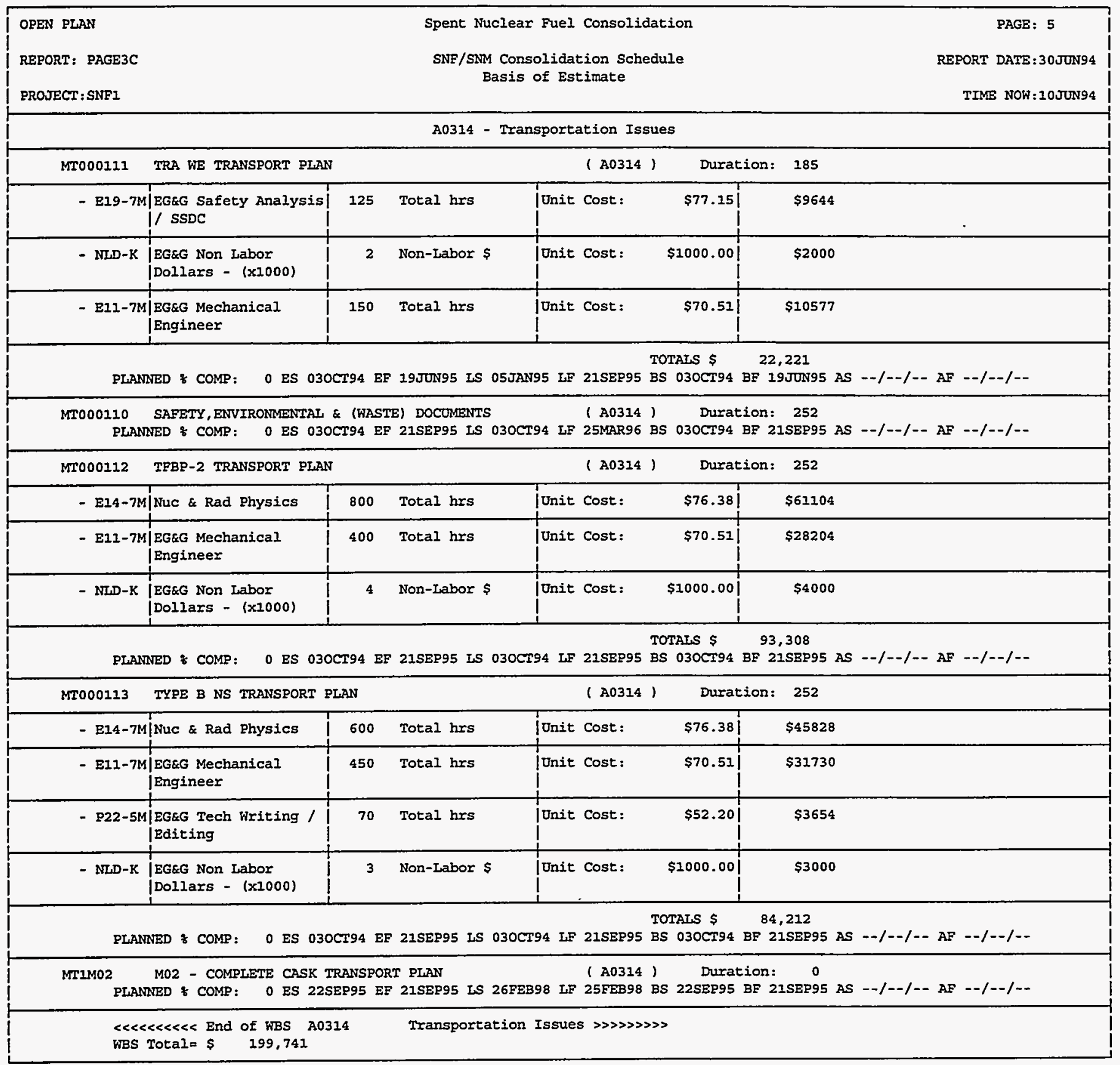

\section{D-27}




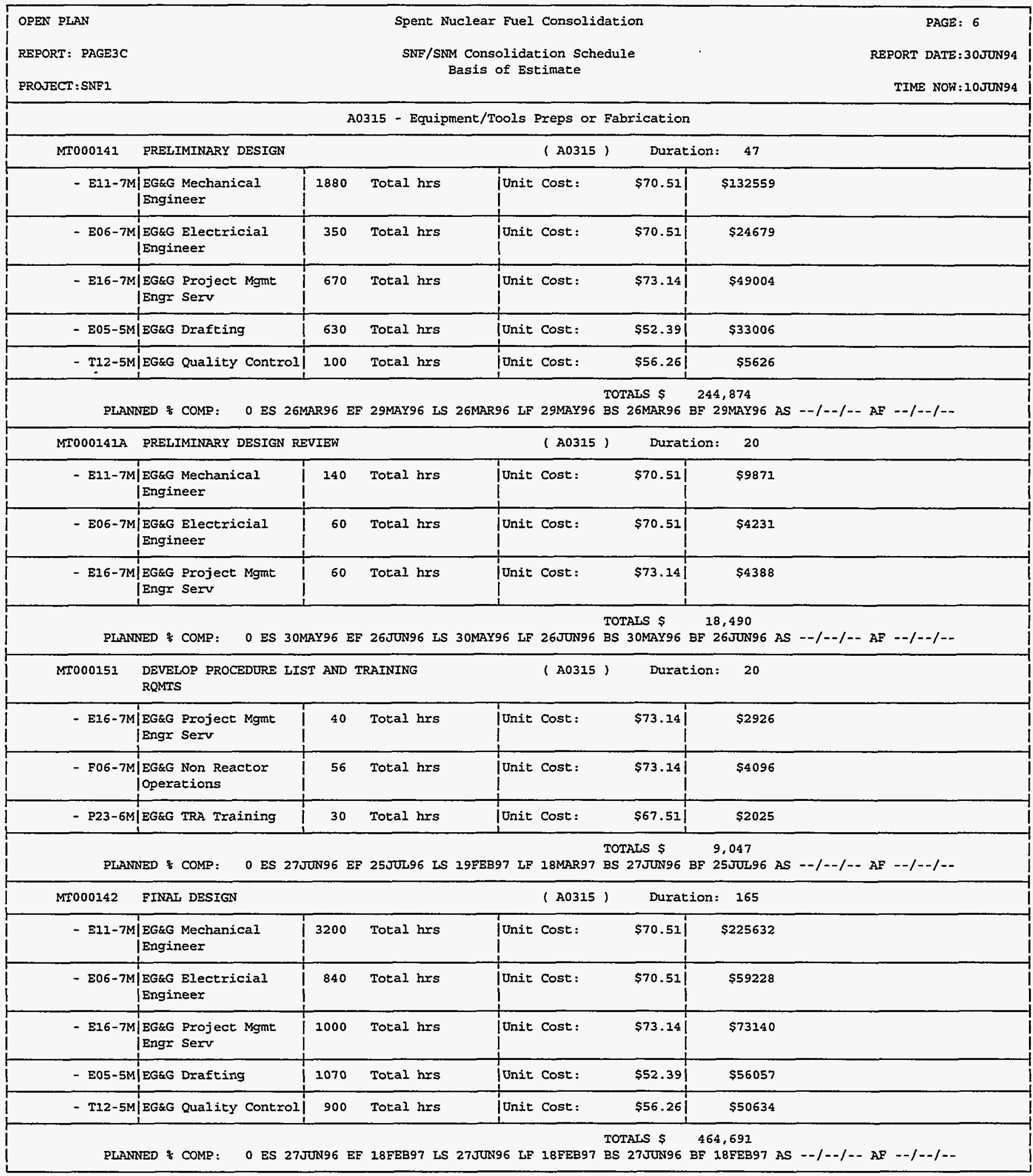




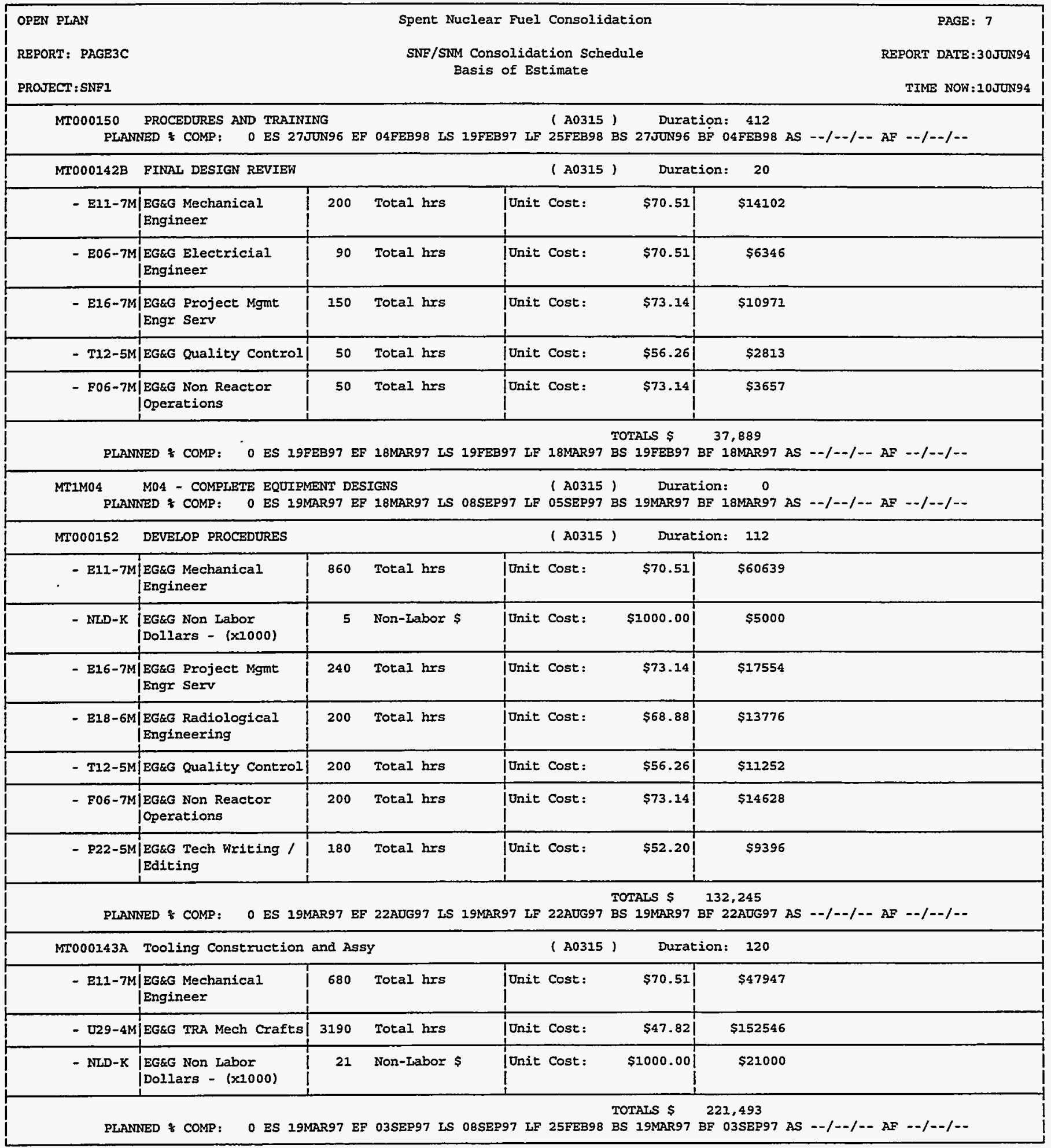




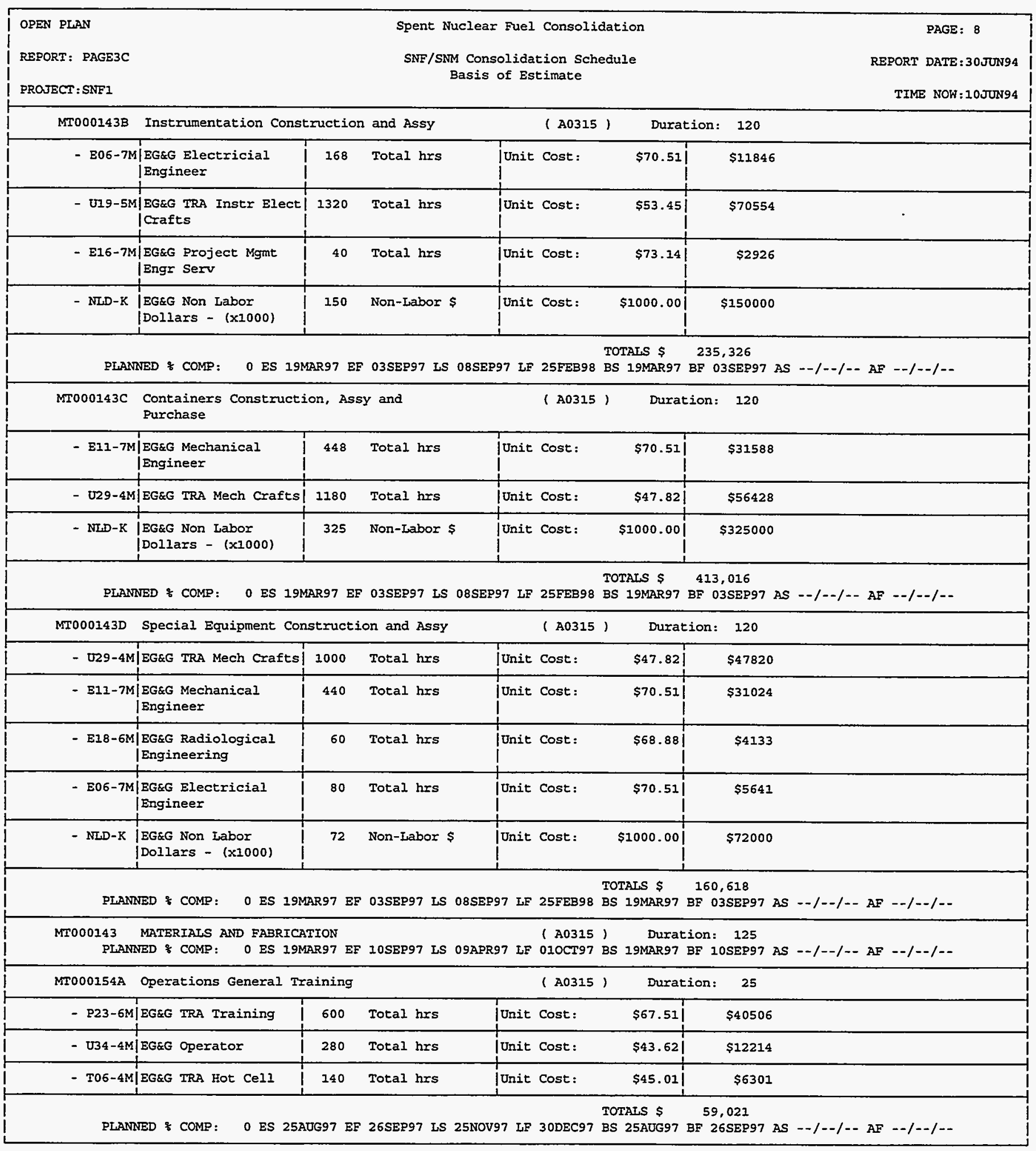




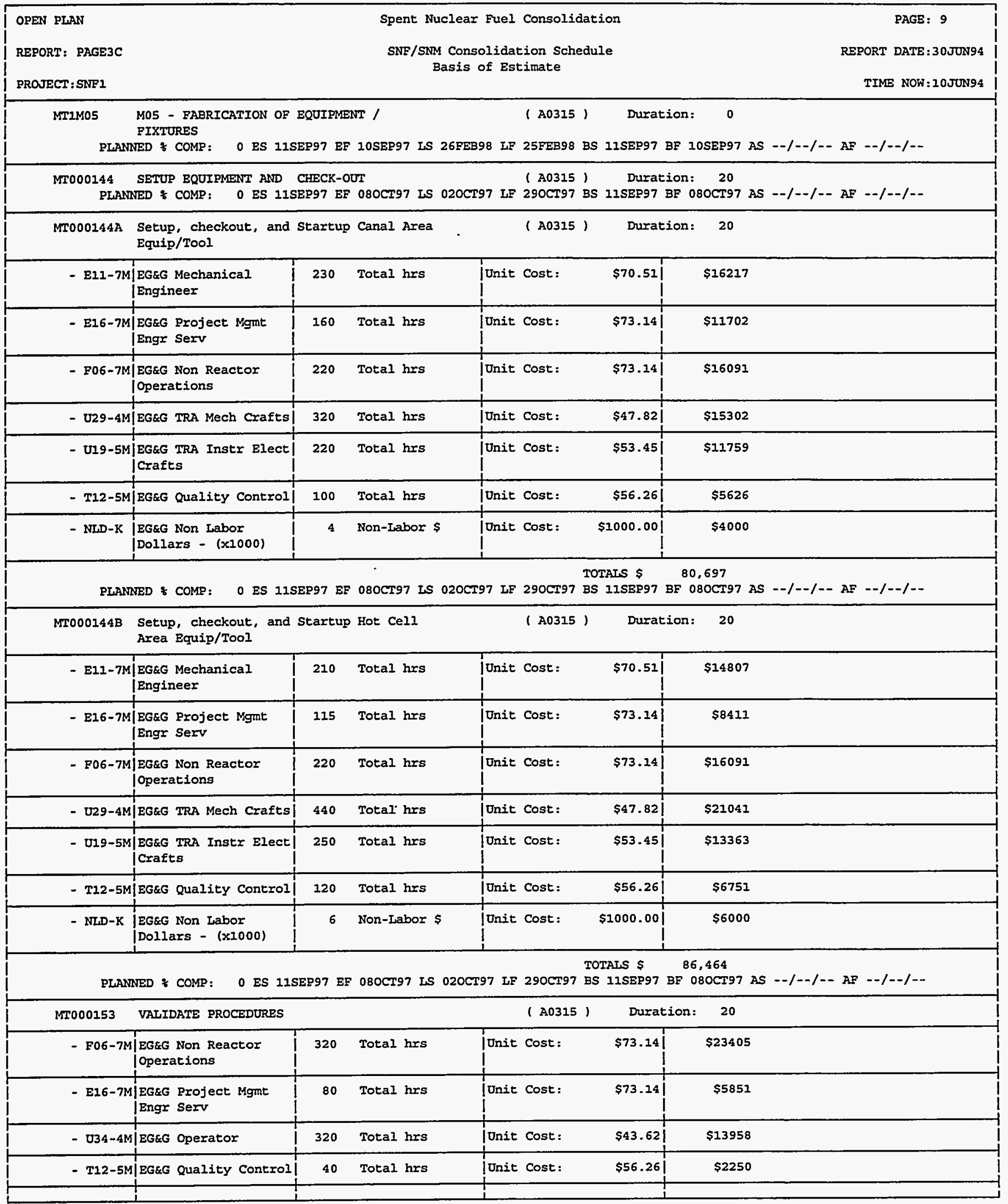




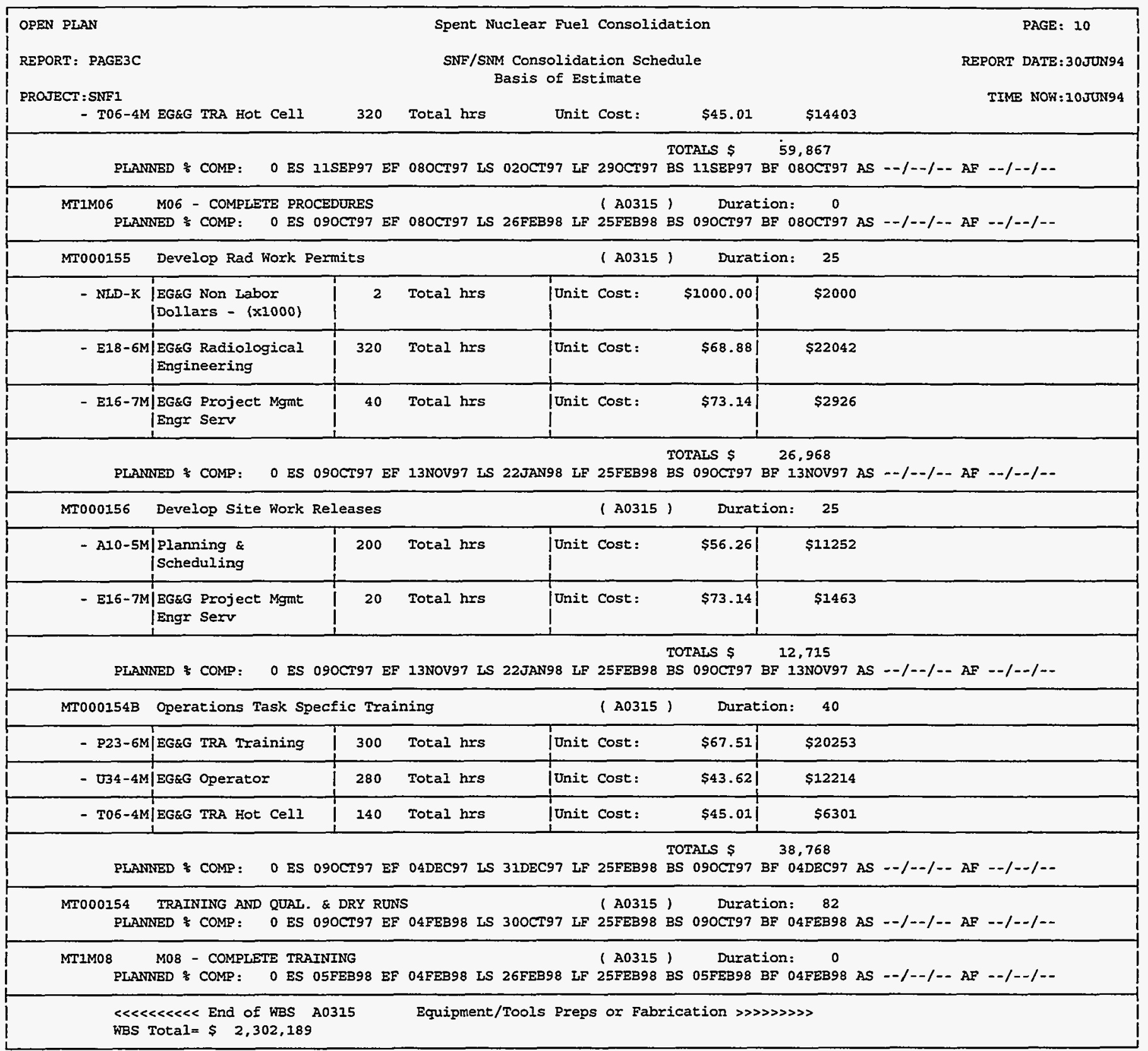




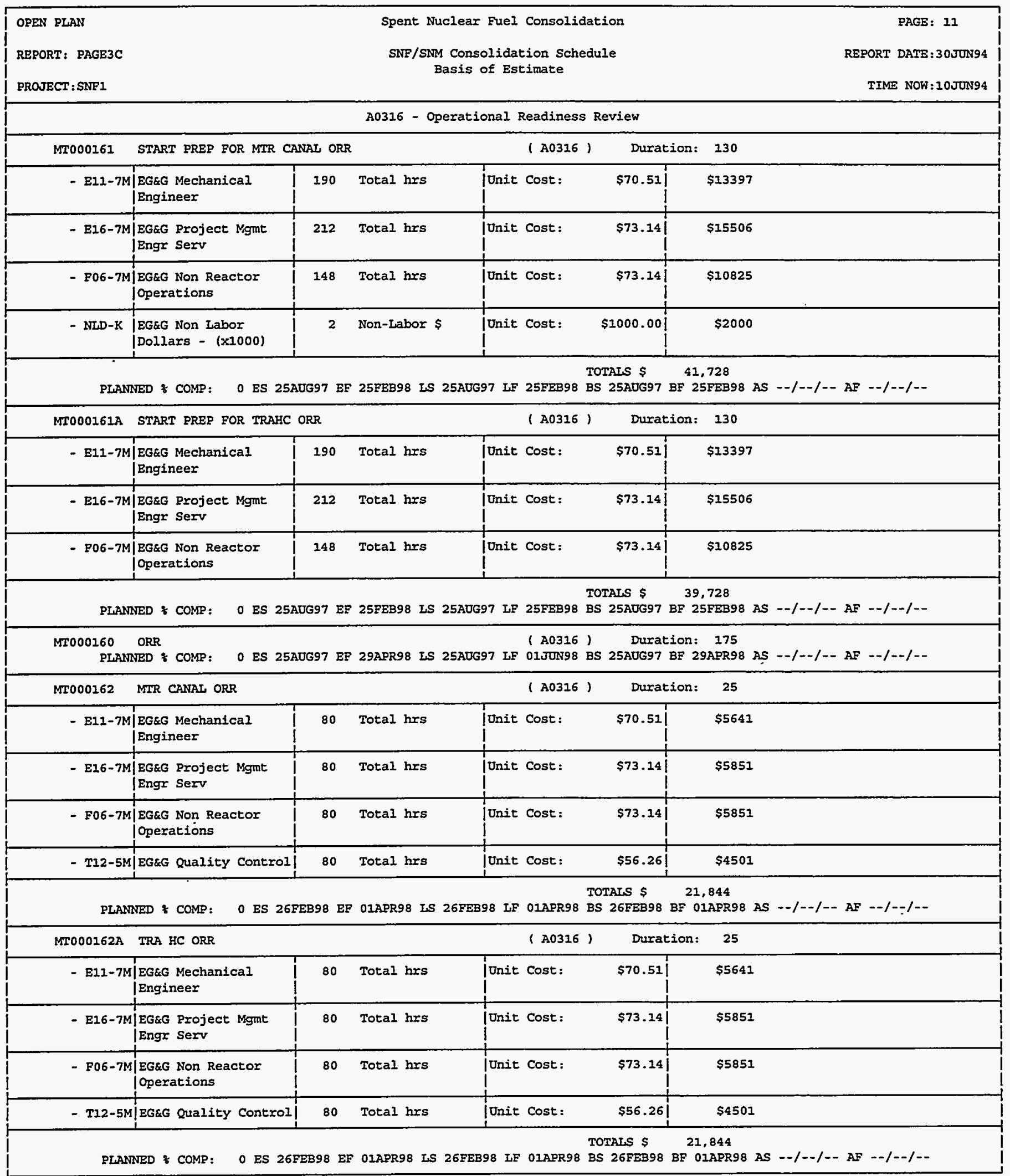




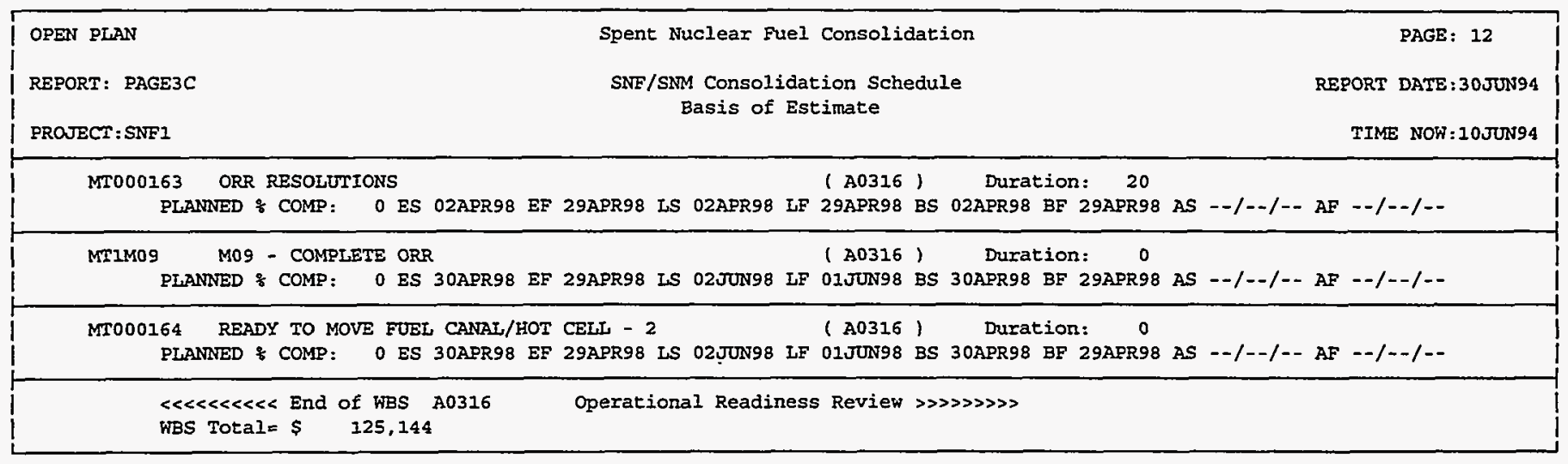




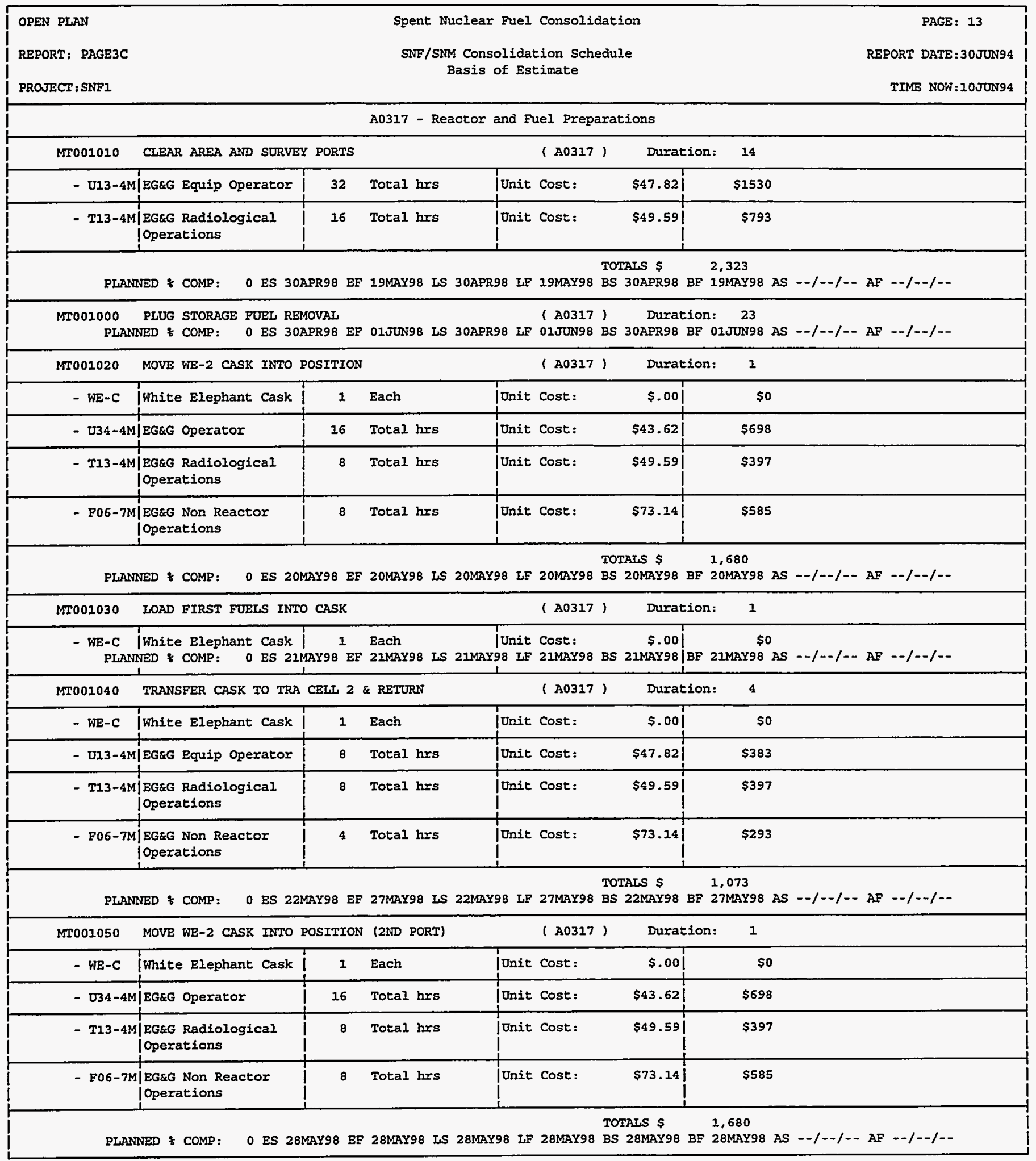

\section{D-35}




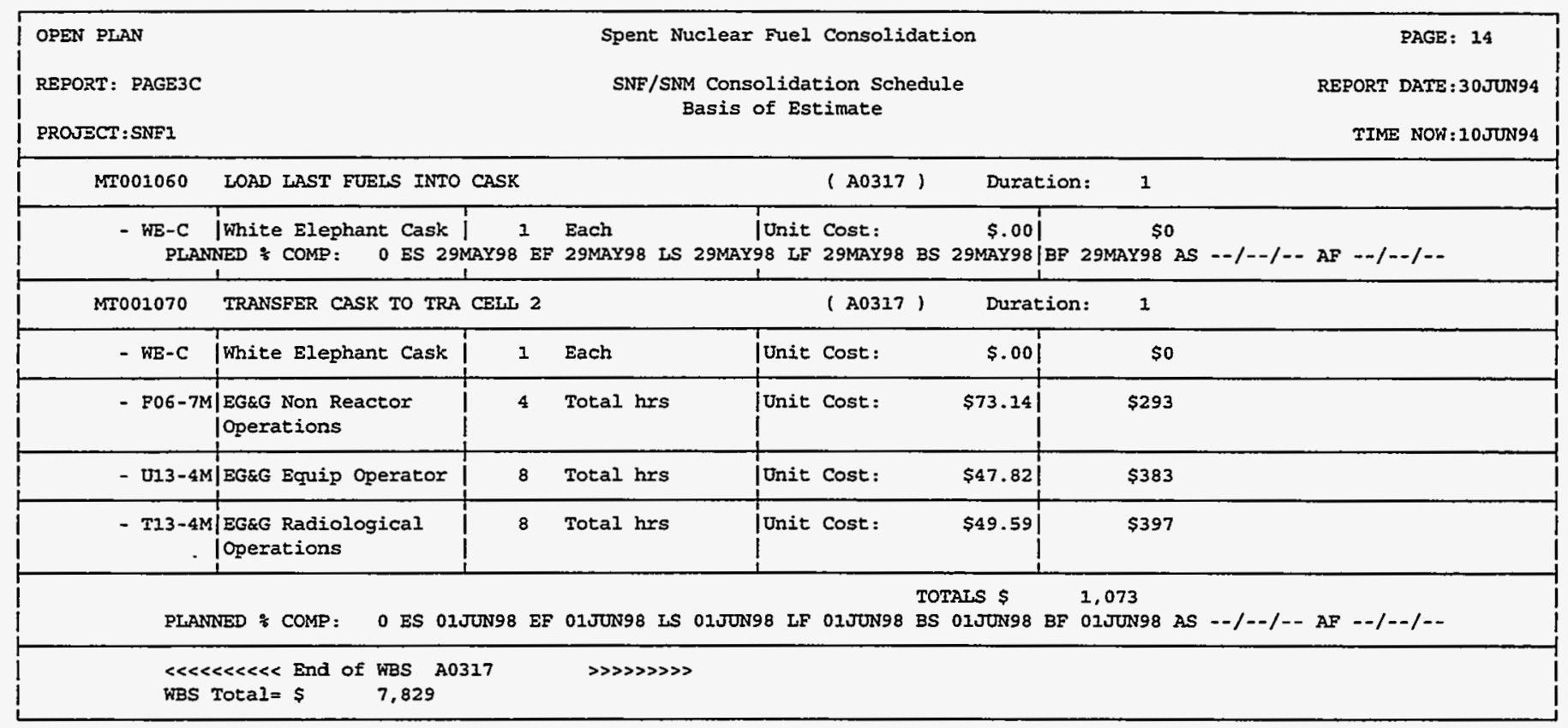




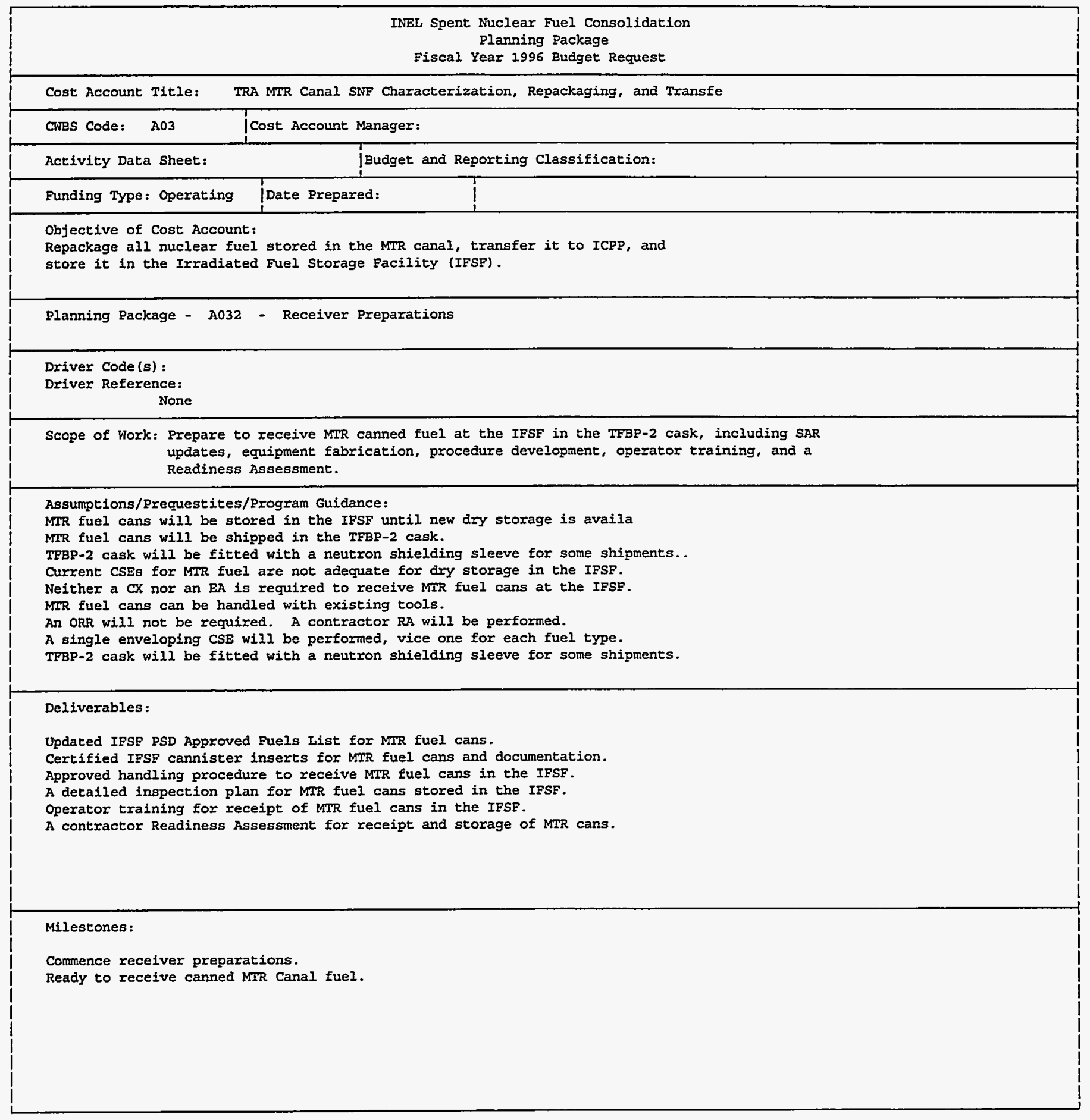

\section{D-37}


SNF/SNM Consolidation Schedule Spent Nuclear Fued Consalidation

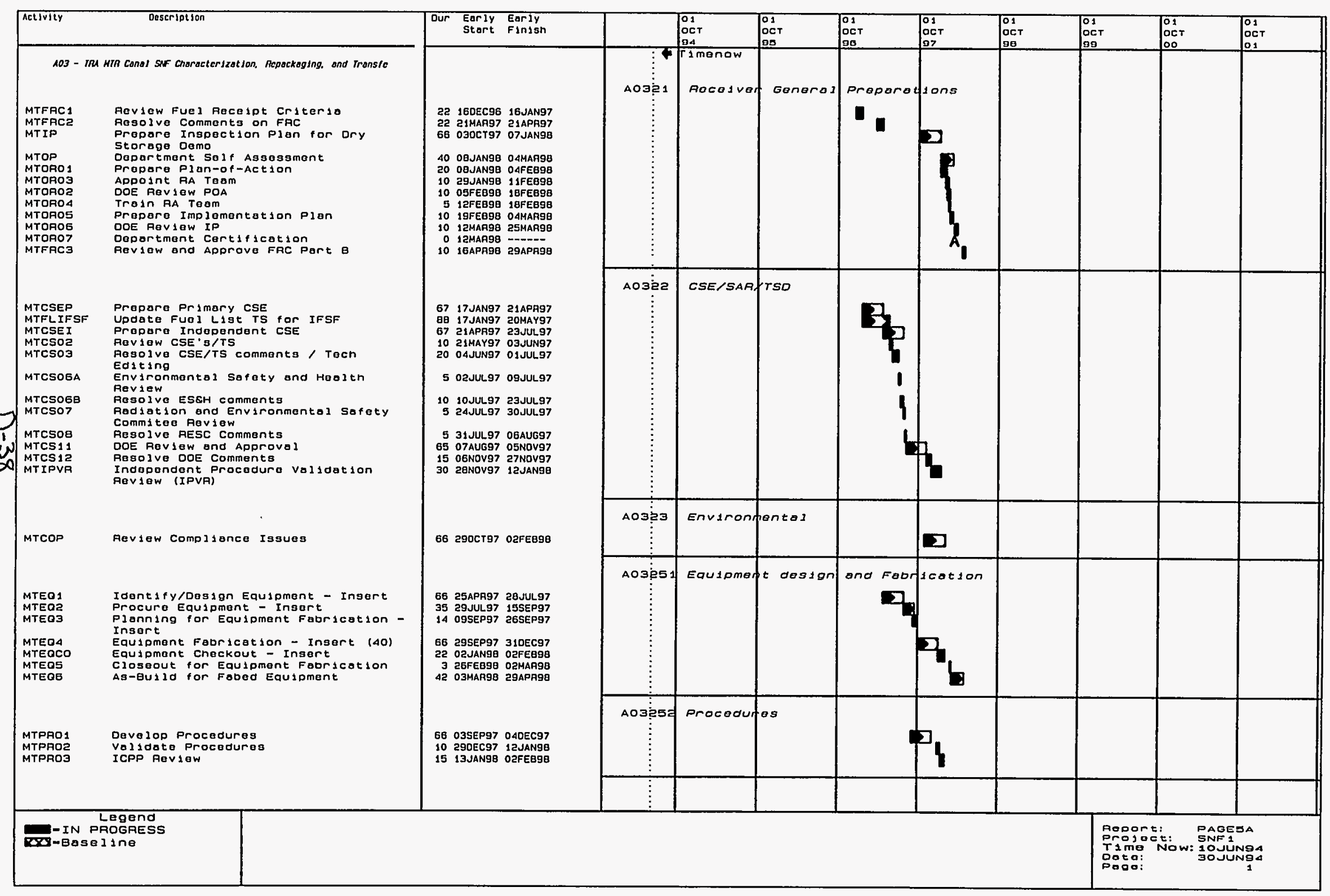


SNF/SNM Consolidation Schedule

Spant Nuclear Fucl Consol guation

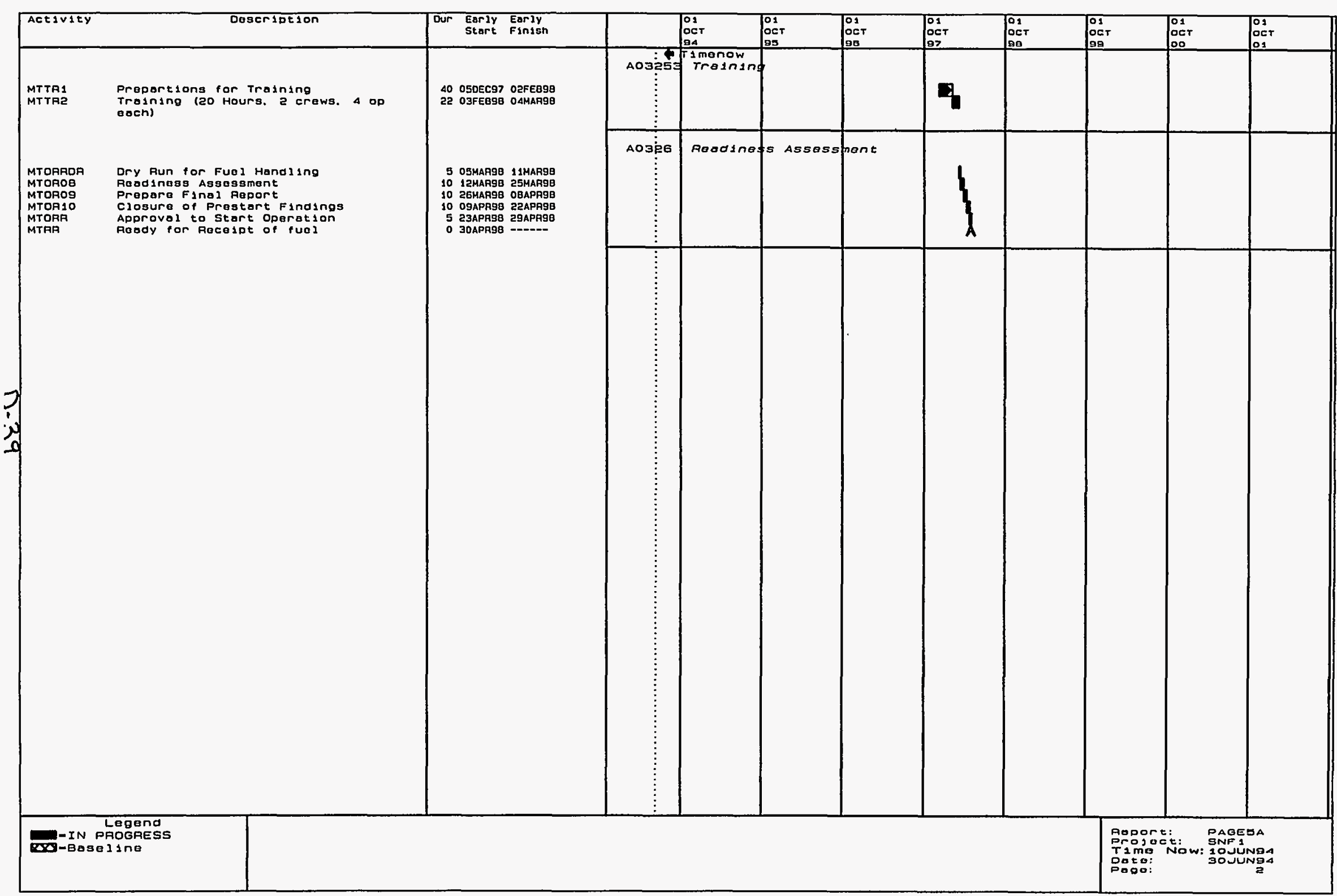




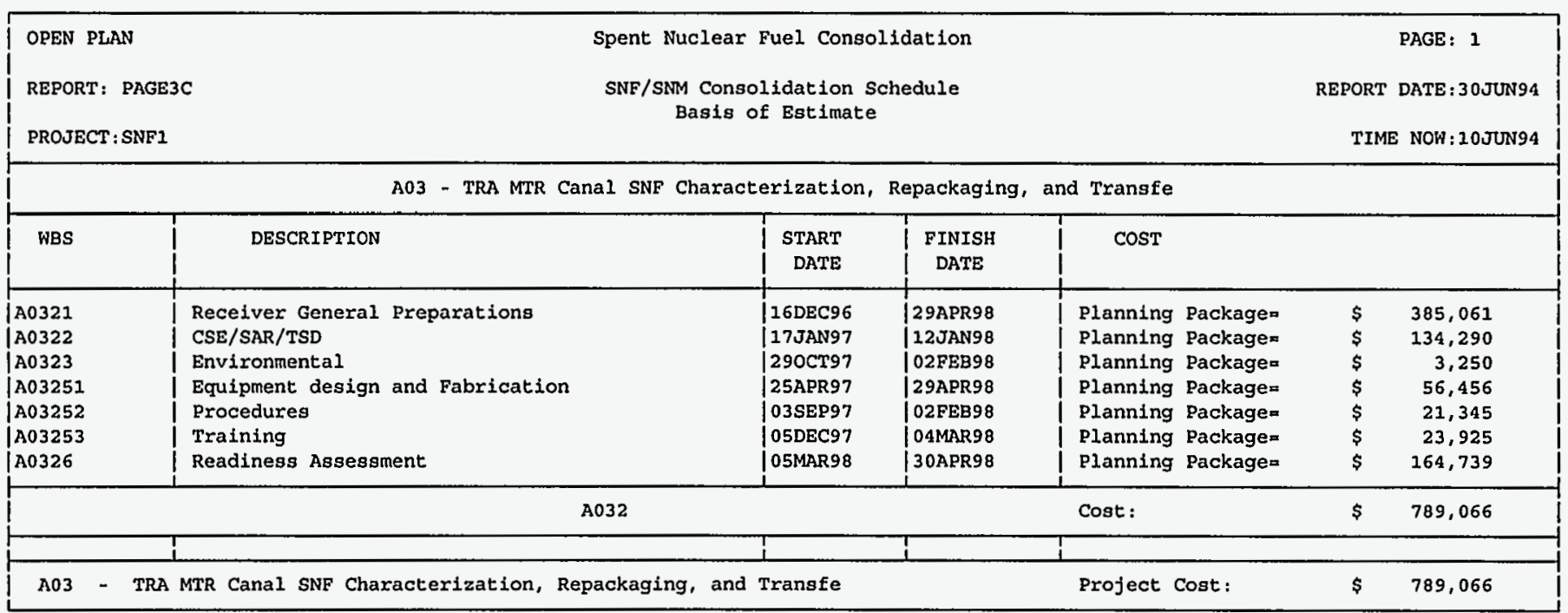

0
1
0 


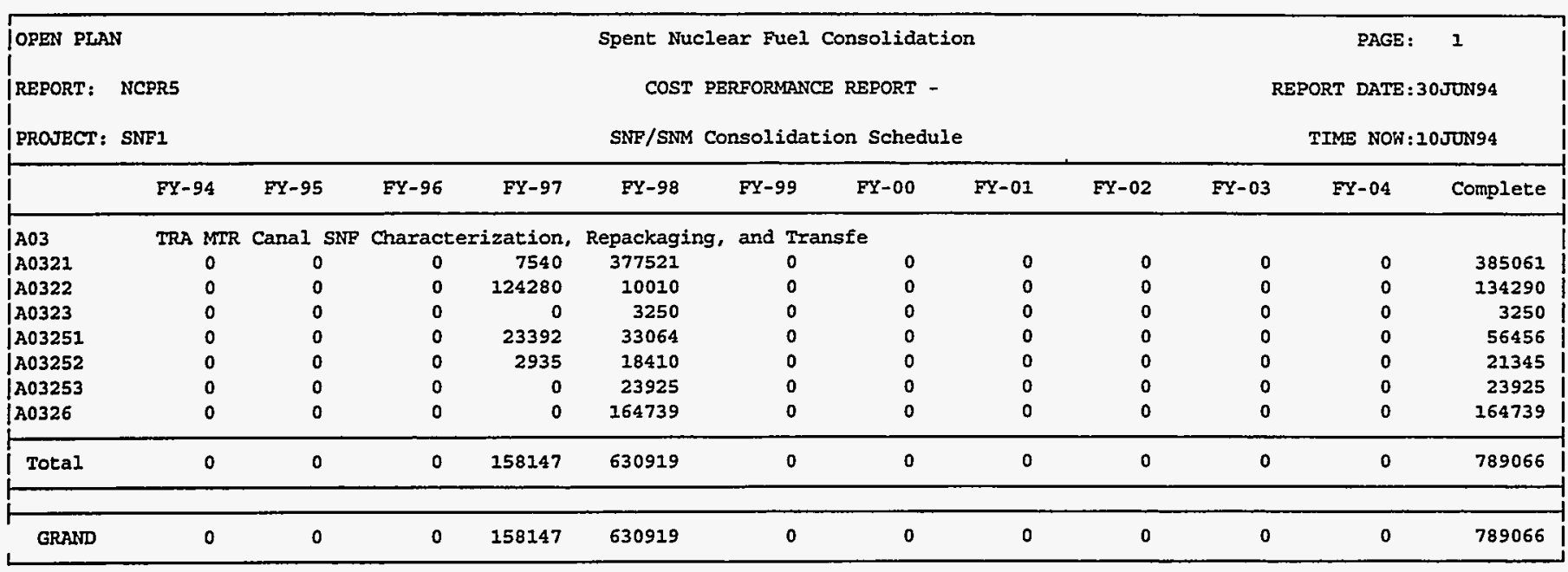




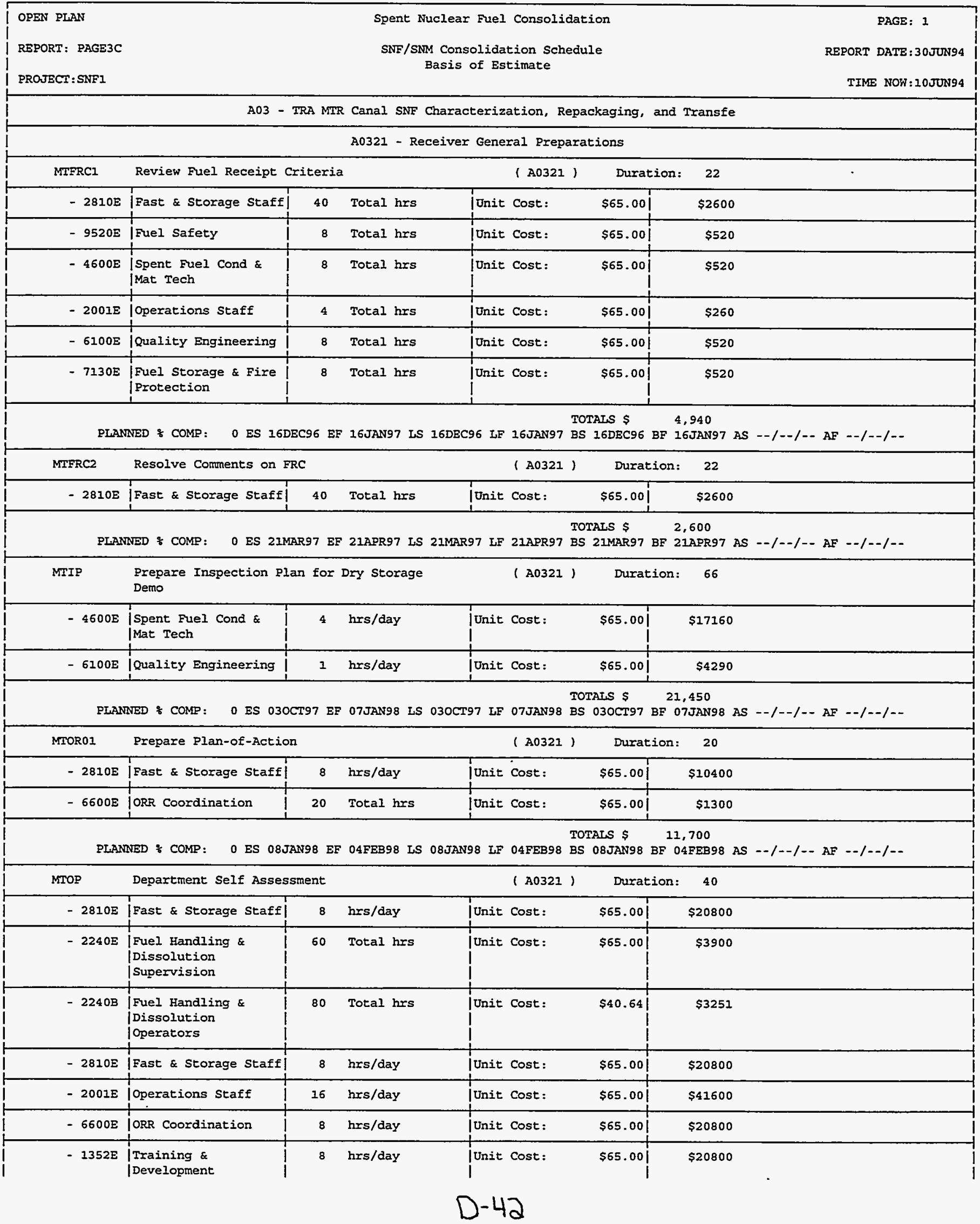




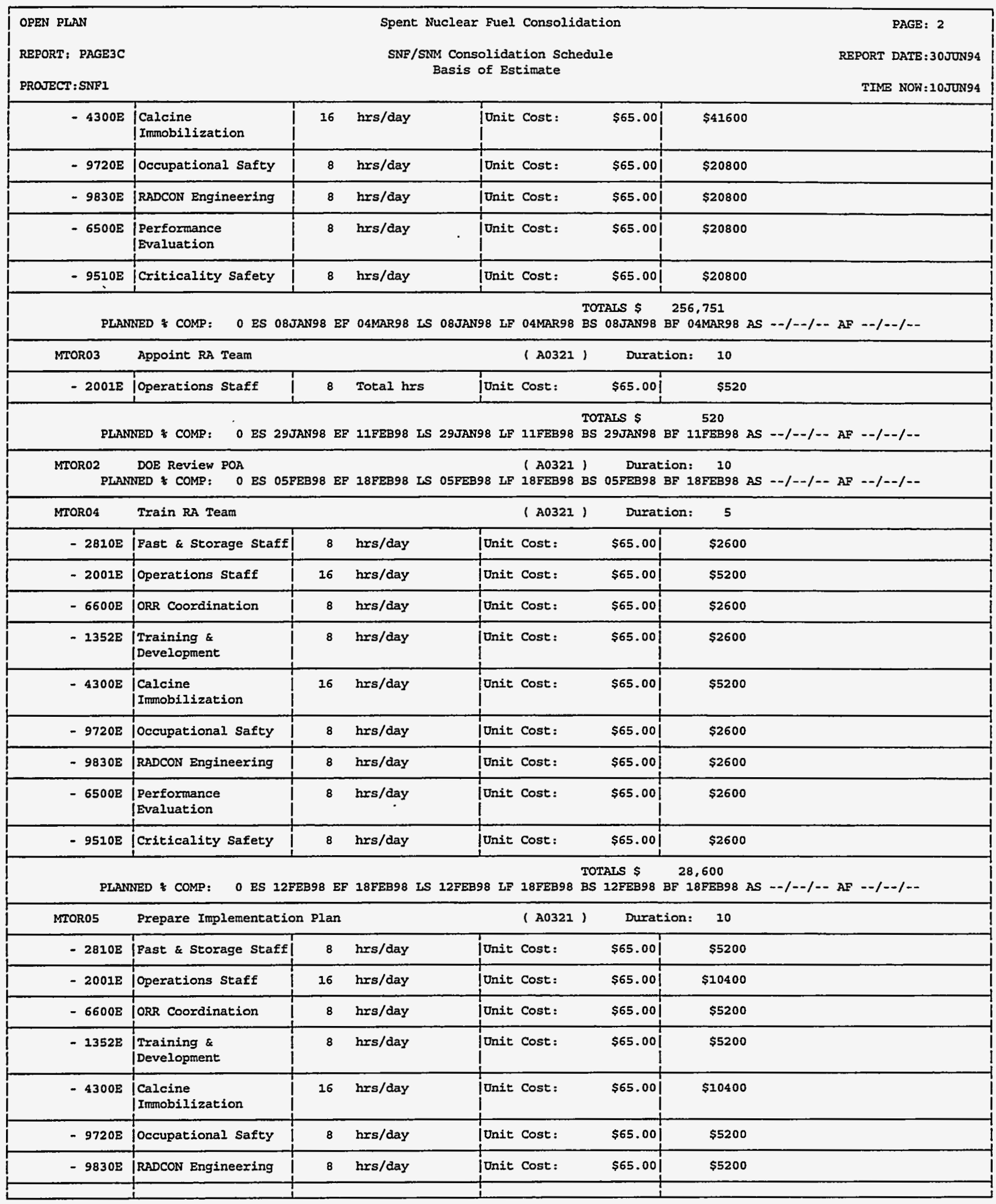

\section{$D-43$}




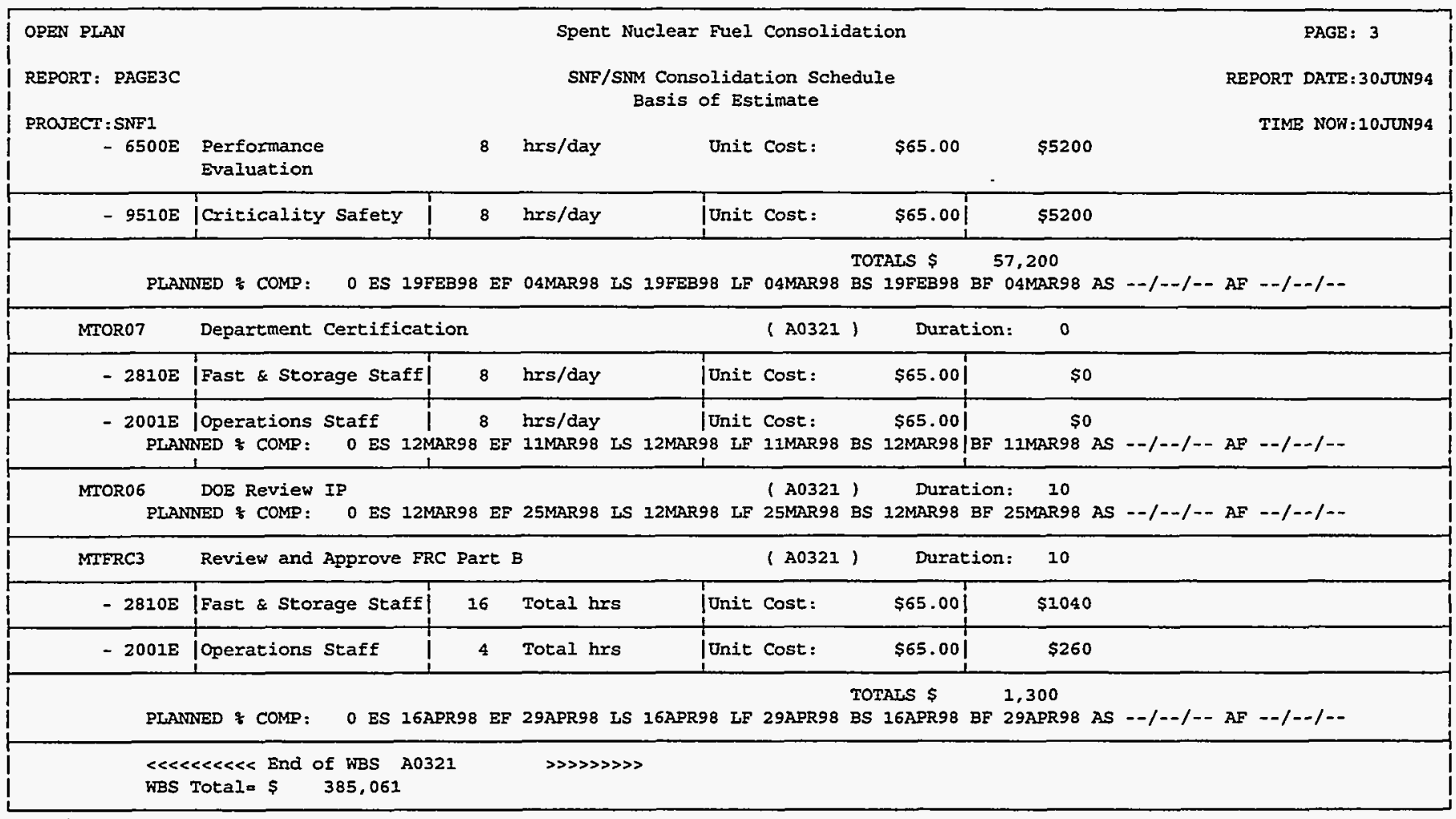




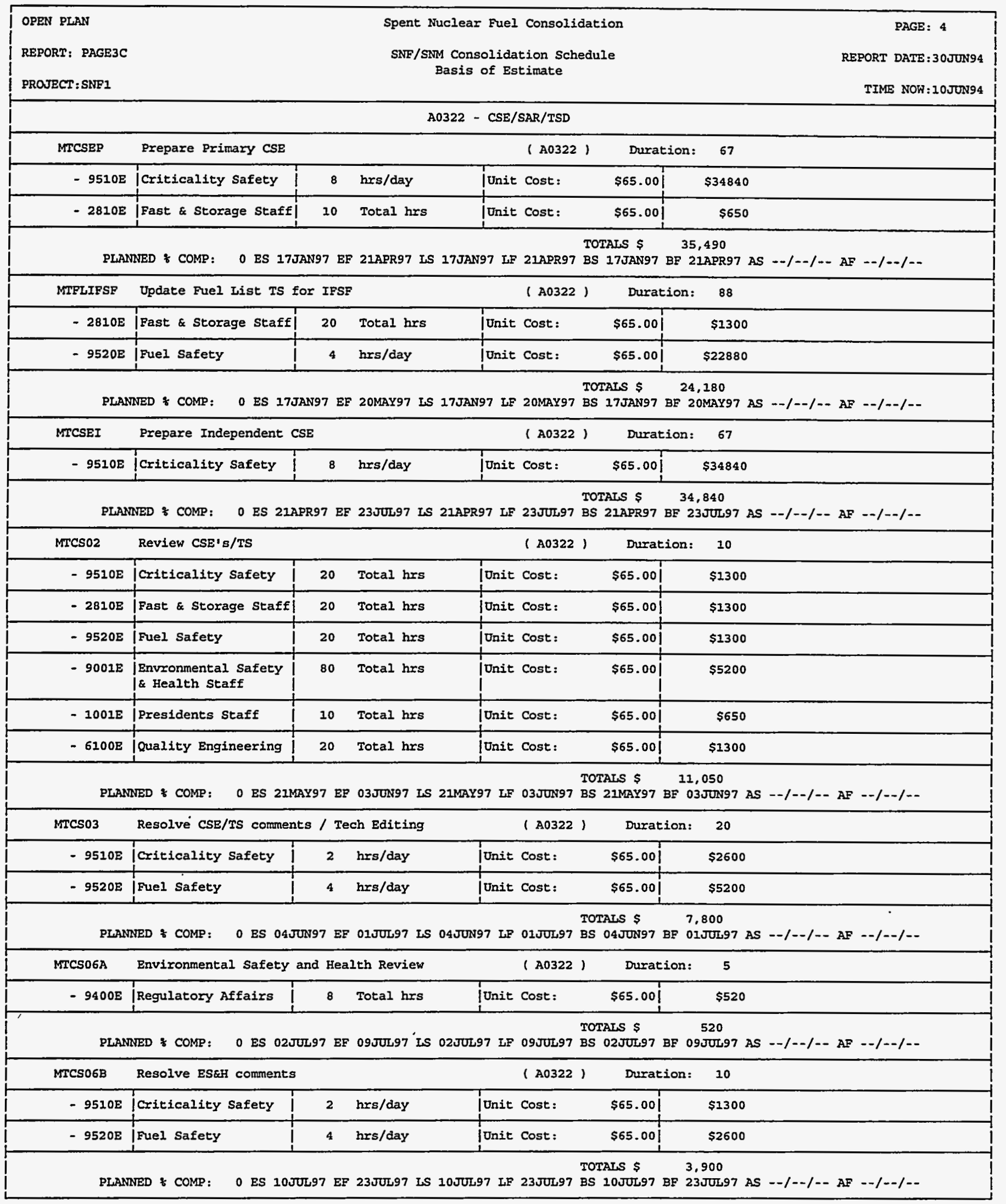

\section{$D-45$}




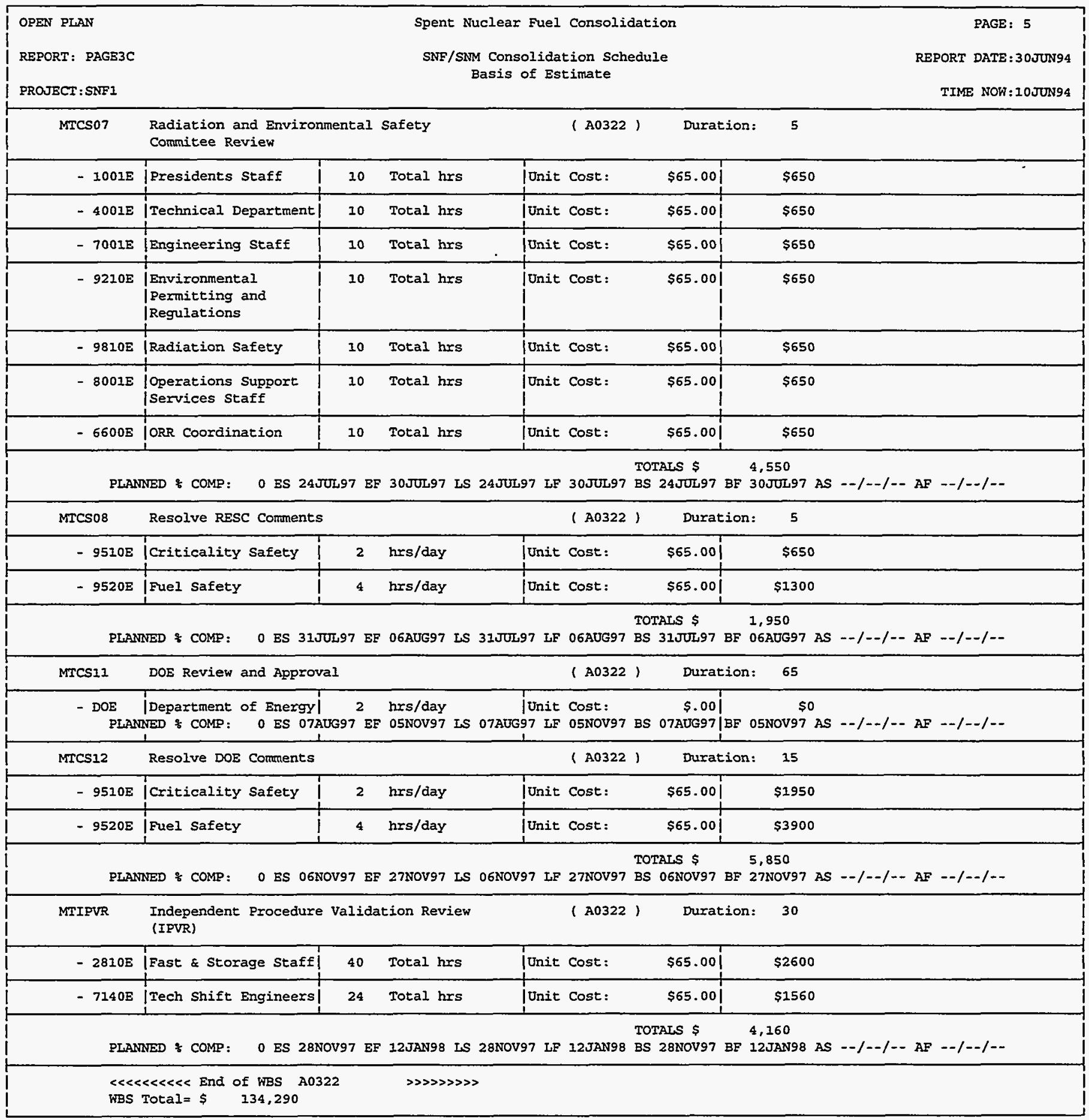




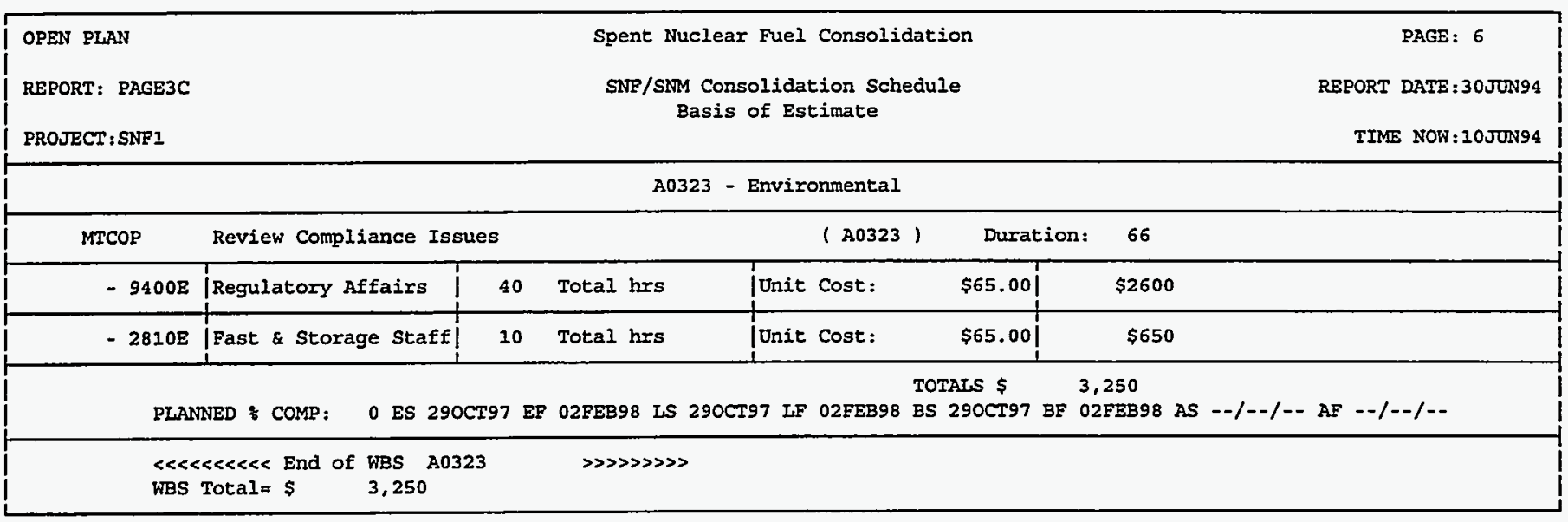

\section{D -47}




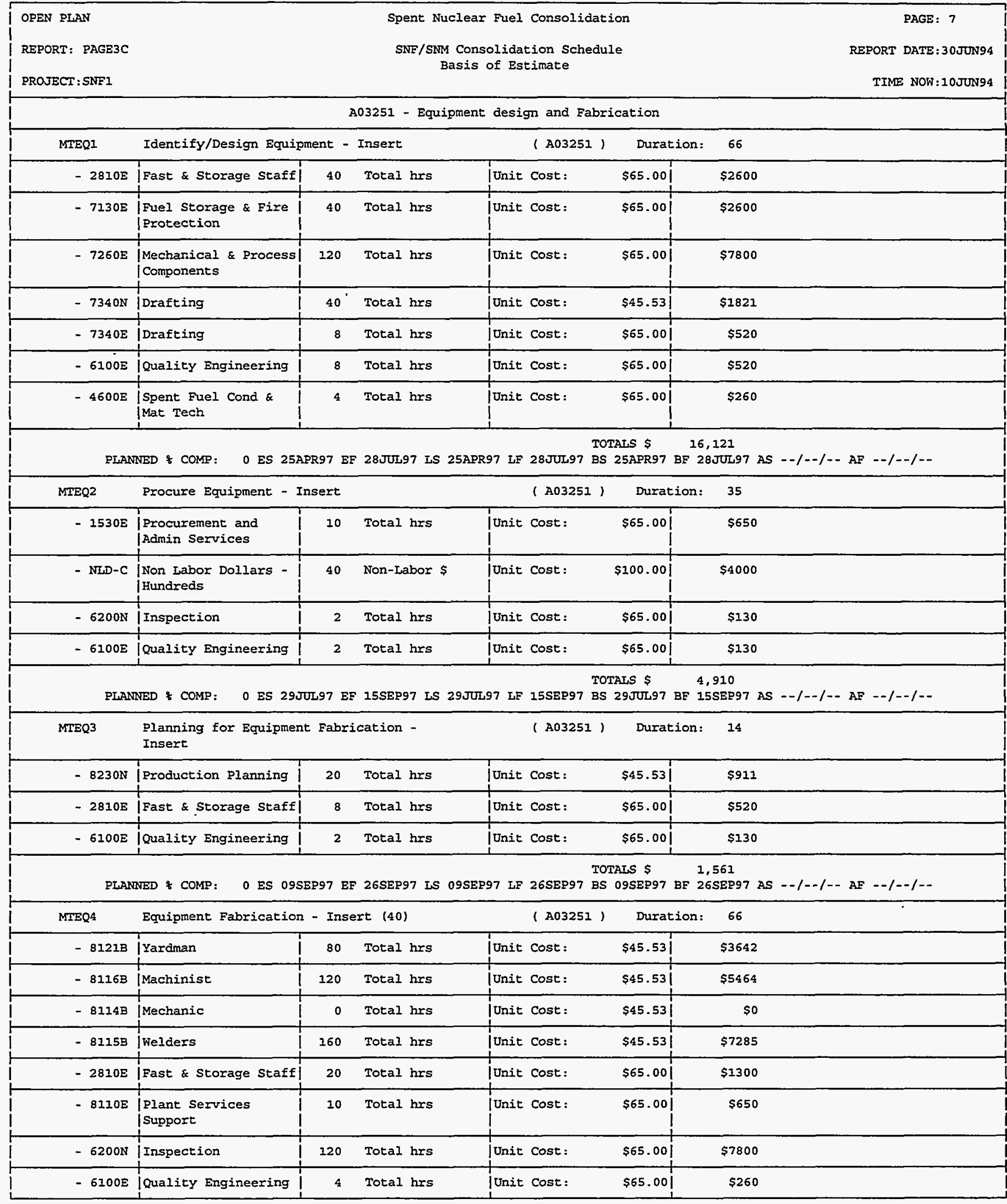




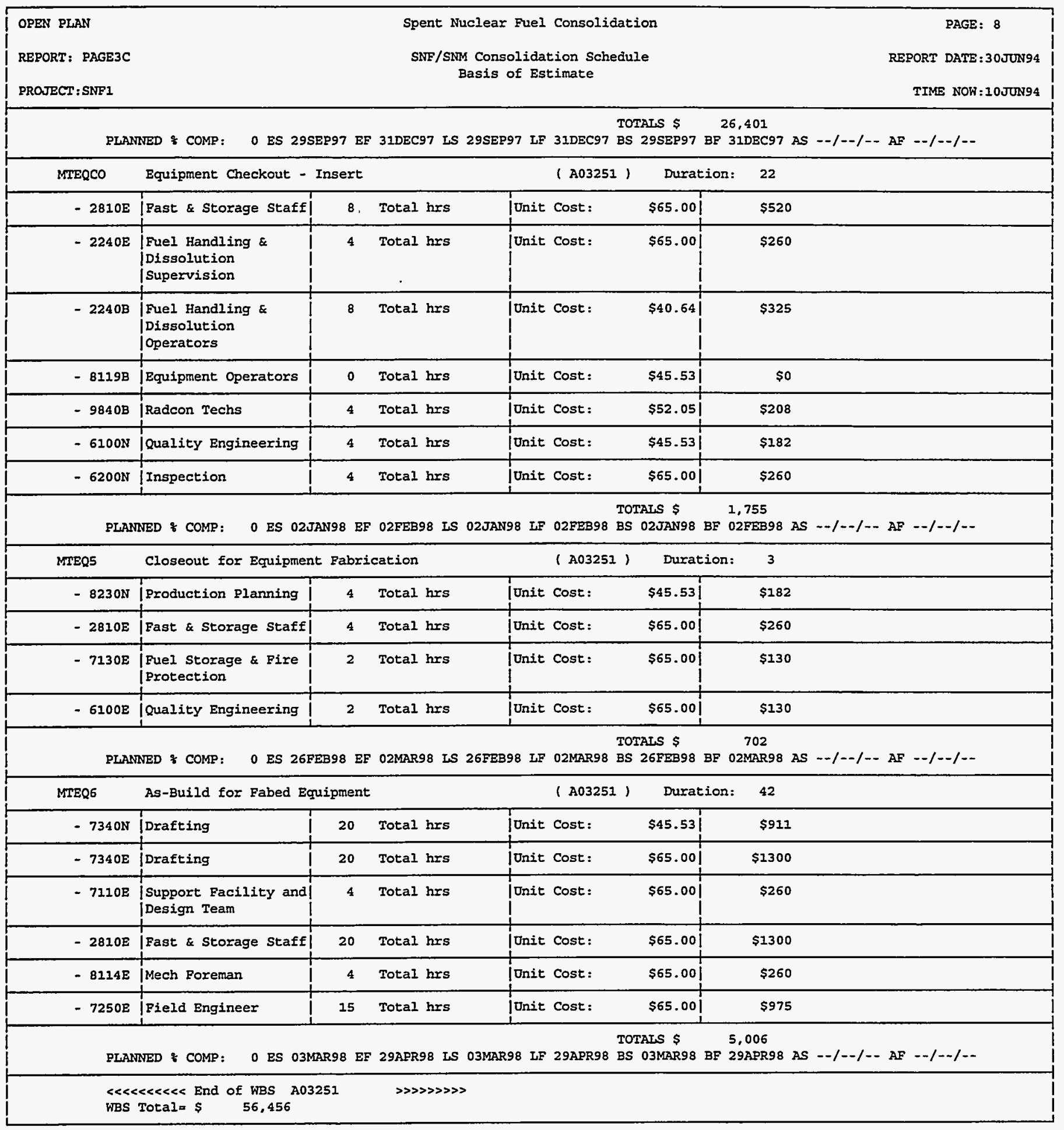

\section{$D-49$}




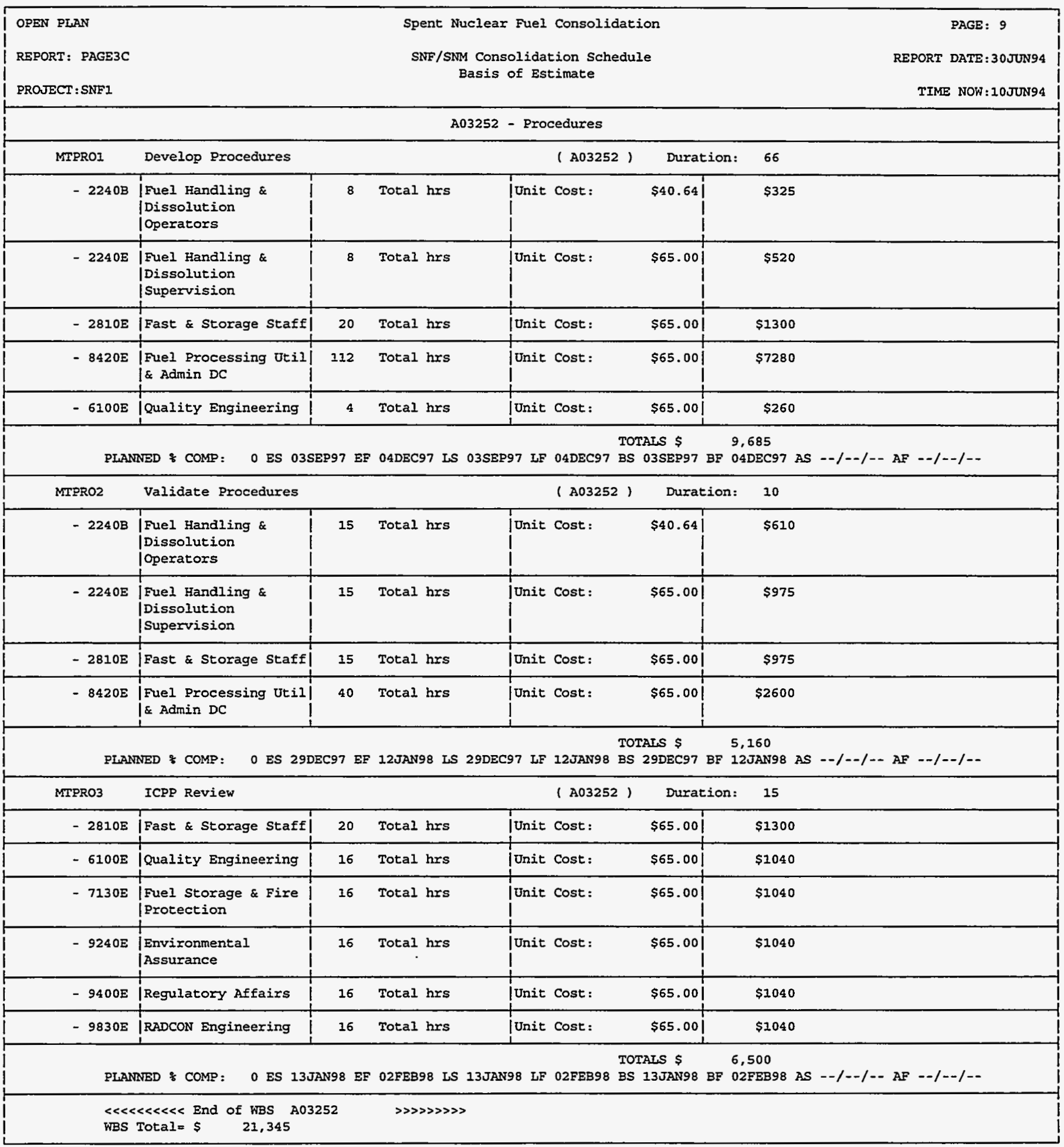




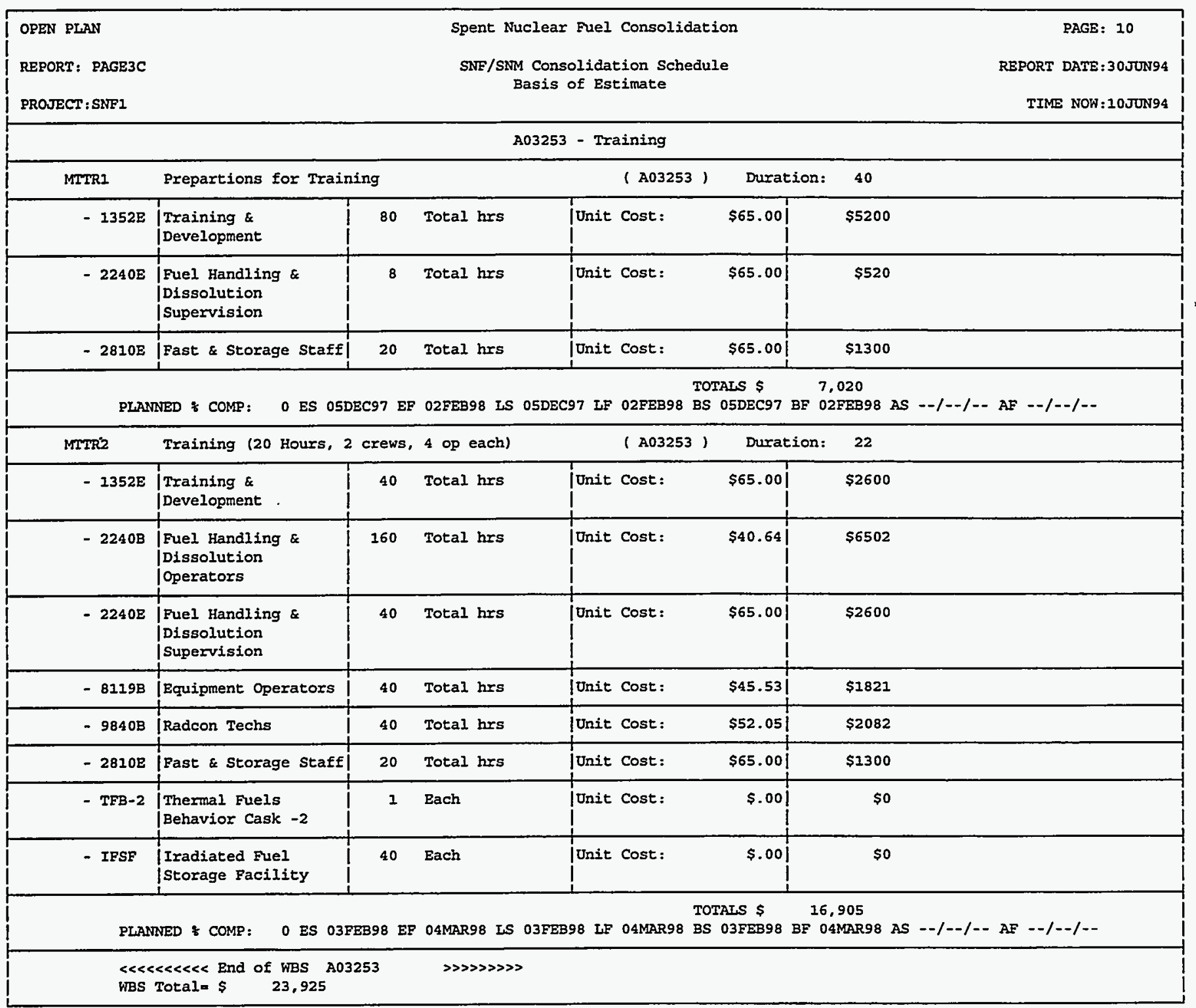




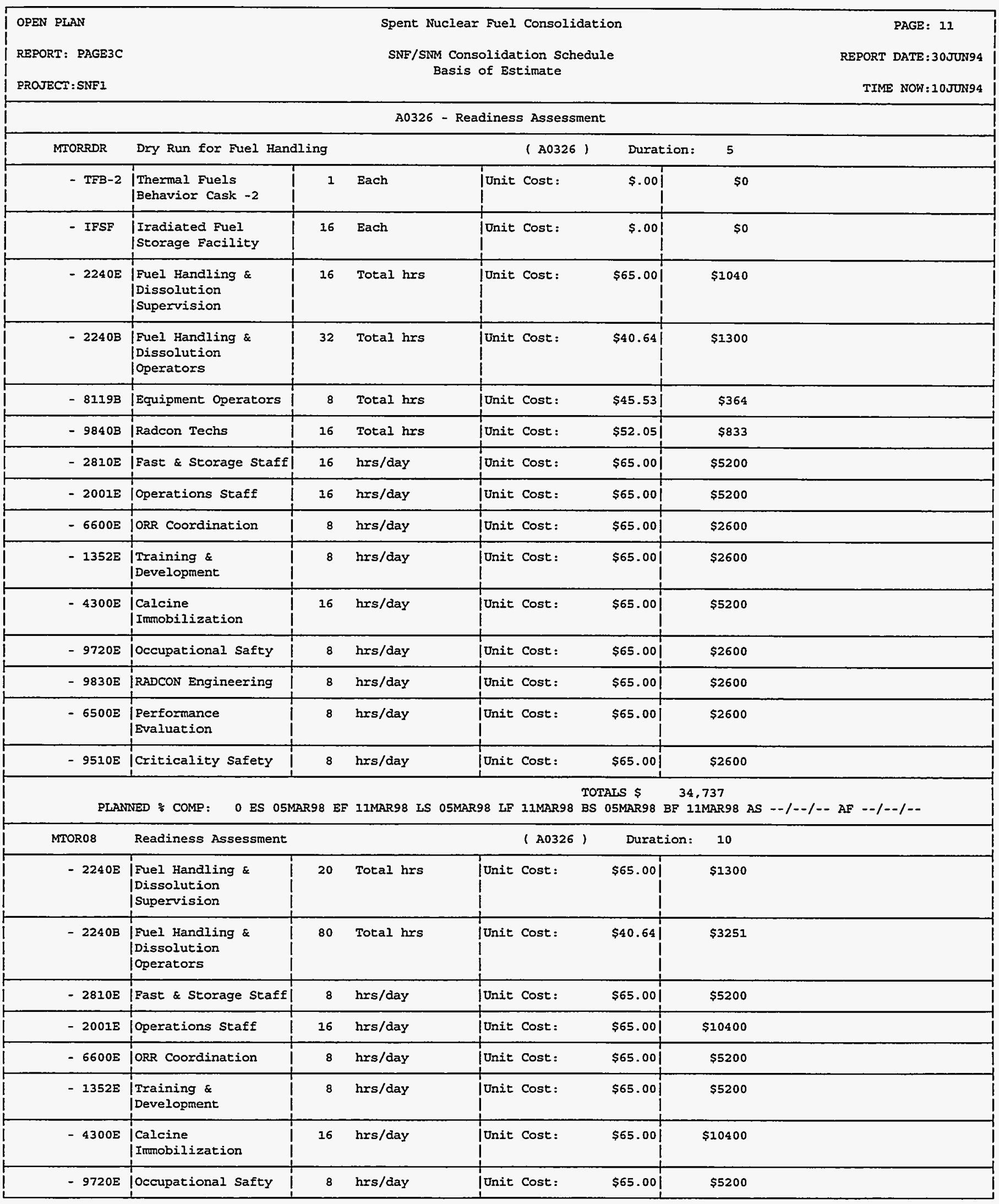




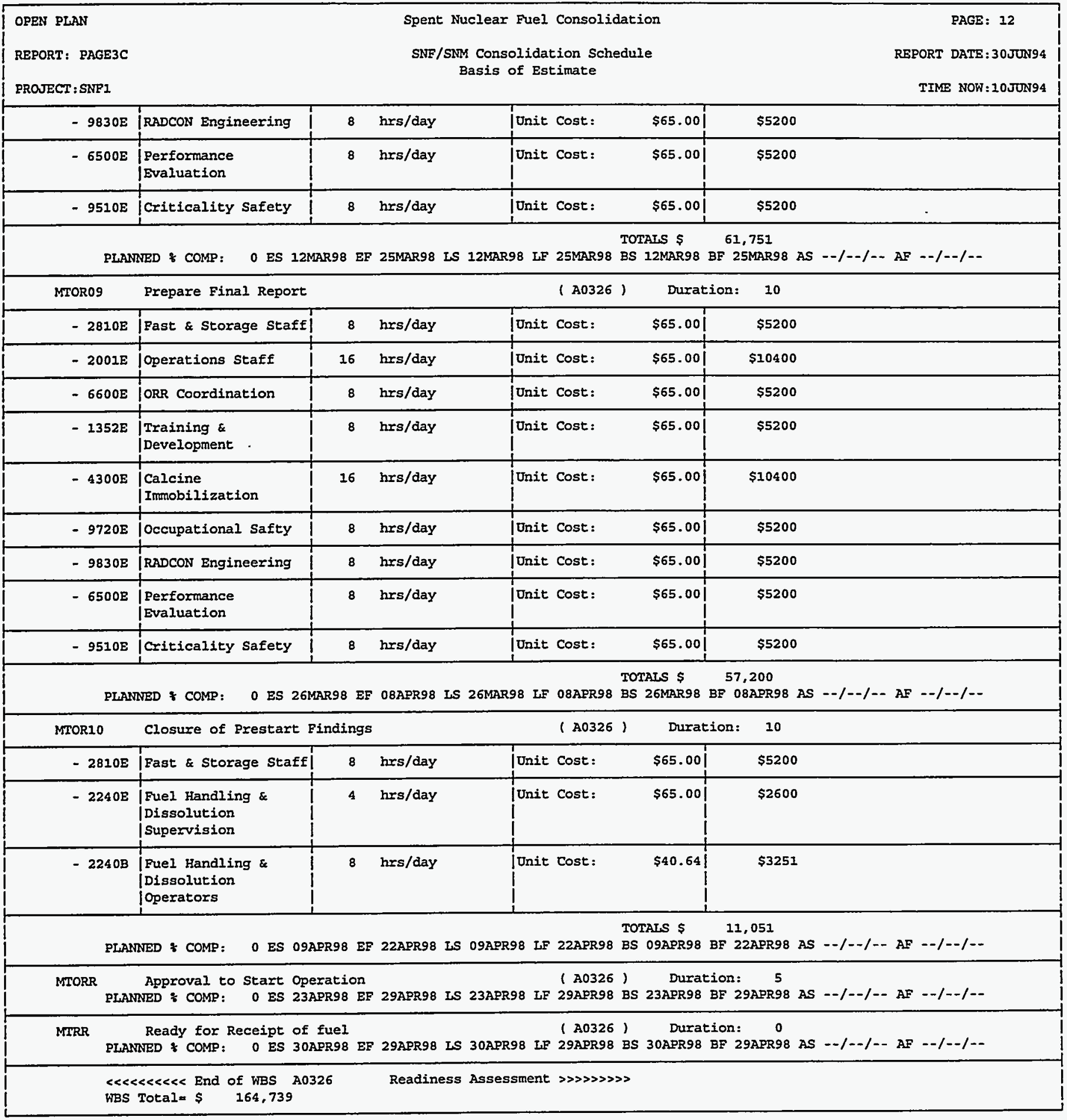

\section{$D-53$}




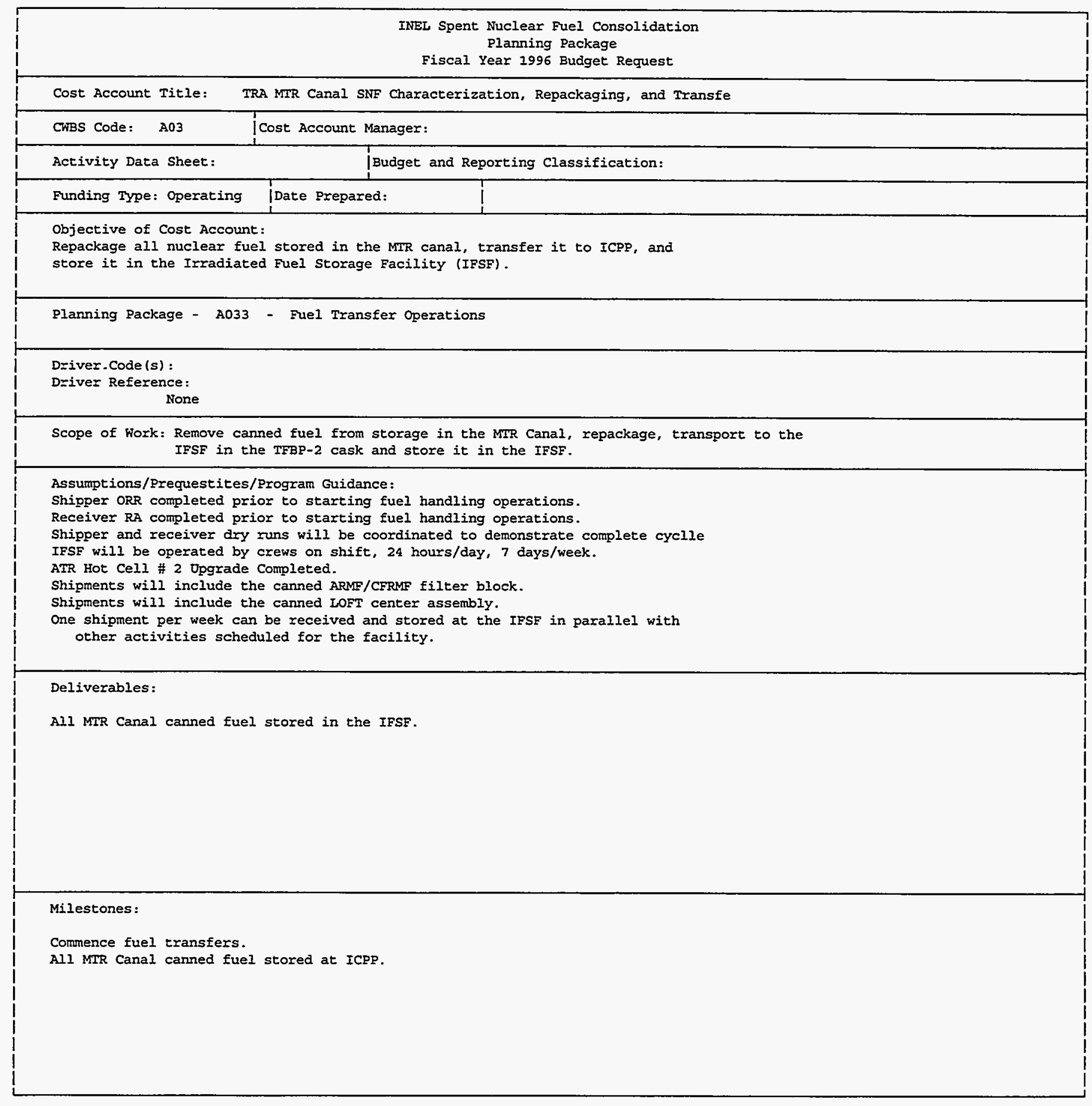




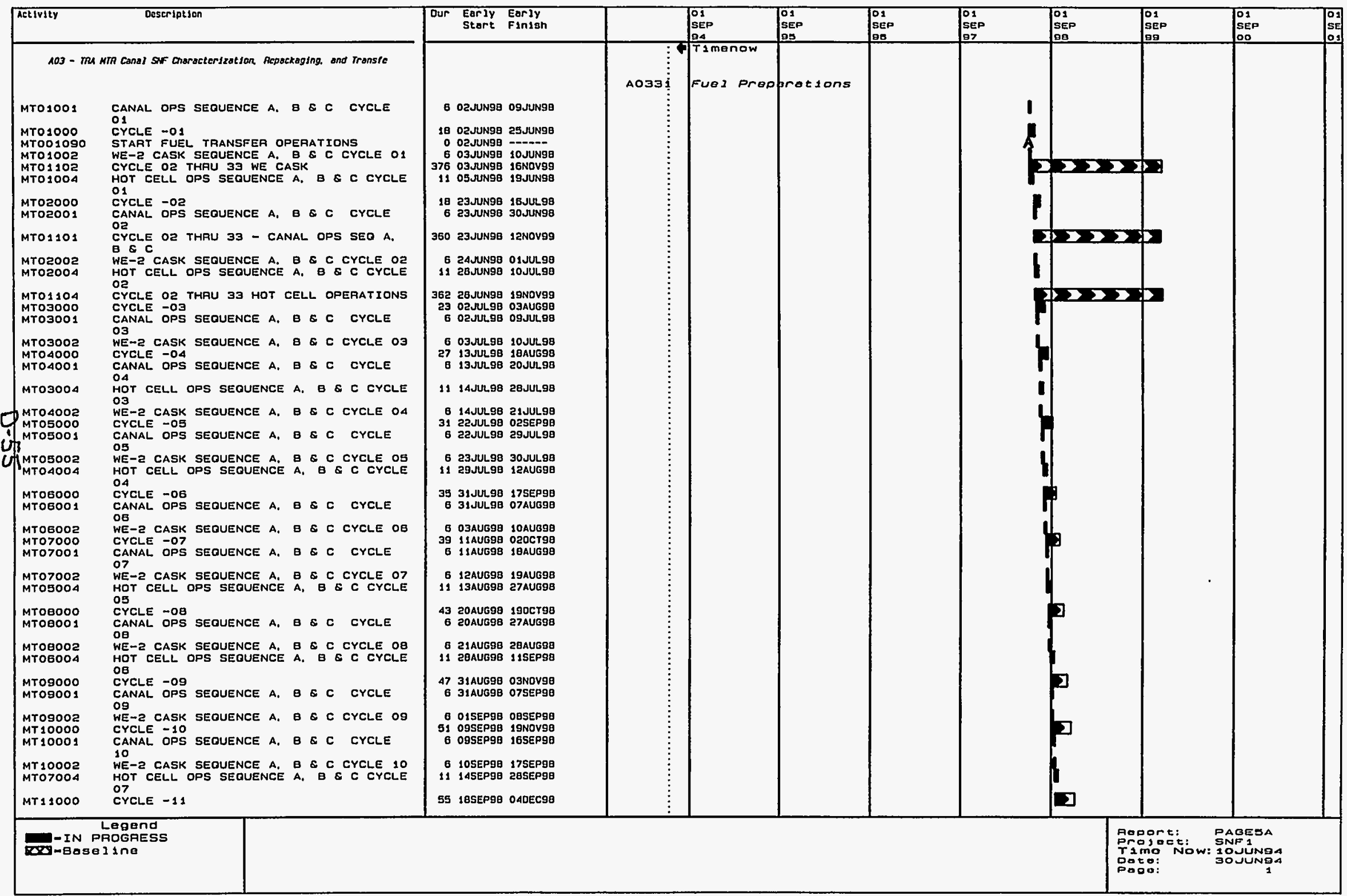


SNF/SNM Consolidation Schedule

\begin{tabular}{|c|c|c|c|c|c|c|c|c|c|c|}
\hline Activity & Doscription & \begin{tabular}{|c|c|} 
Our Early & Early \\
Start & Finjon \\
\end{tabular} & $\begin{array}{l}0.1 \\
\operatorname{sep} \\
\operatorname{lod}\end{array}$ & $\mid \begin{array}{l}01 \\
\text { Sefp } \\
\text { Seg }\end{array}$ & $\mid \begin{array}{l}01 \\
\text { sep } \\
\text { gep }\end{array}$ & {$\left[\begin{array}{l}0,1 \\
\operatorname{sep} \\
07\end{array}\right.$} & $\begin{array}{l}01 \\
\text { SEP } \\
\text { gD }\end{array}$ & {$\left[\begin{array}{l}01 \\
\text { SEFP } \\
\text { geg }\end{array}\right.$} & $\begin{array}{l}\text { o. } \\
\text { sep } \\
\text { oo }\end{array}$ & $\begin{array}{ll}0 \\
\text { se } \\
0.1 \\
01\end{array}$ \\
\hline 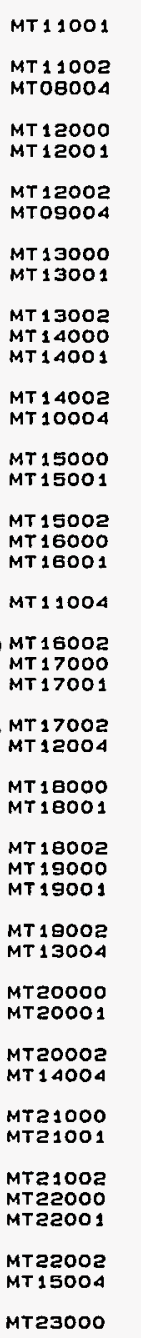 & 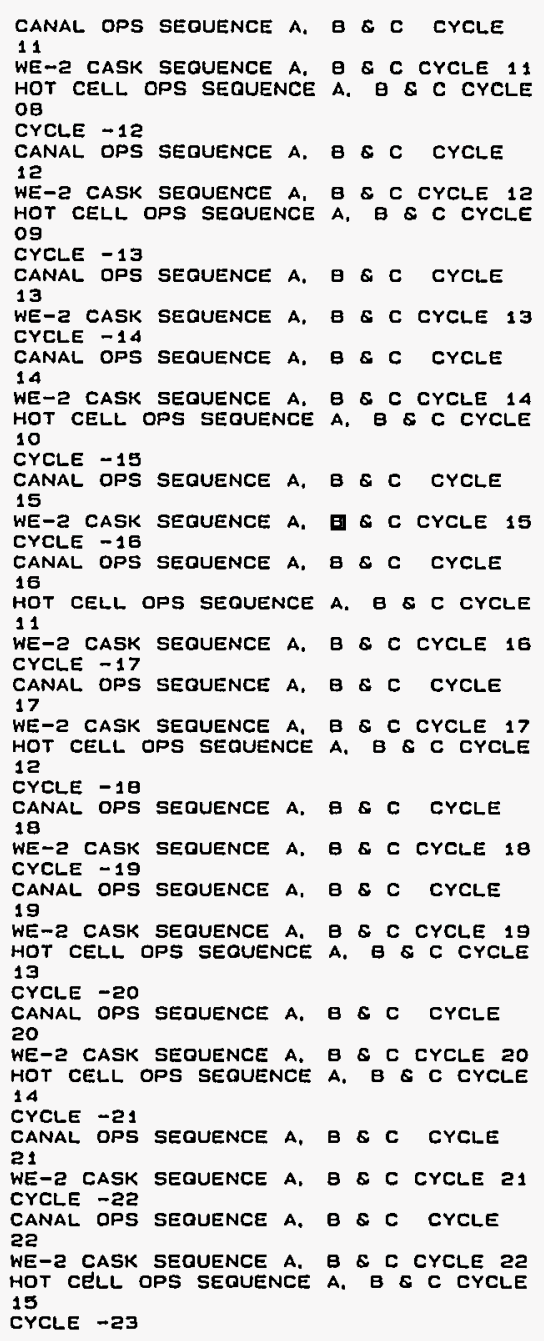 & 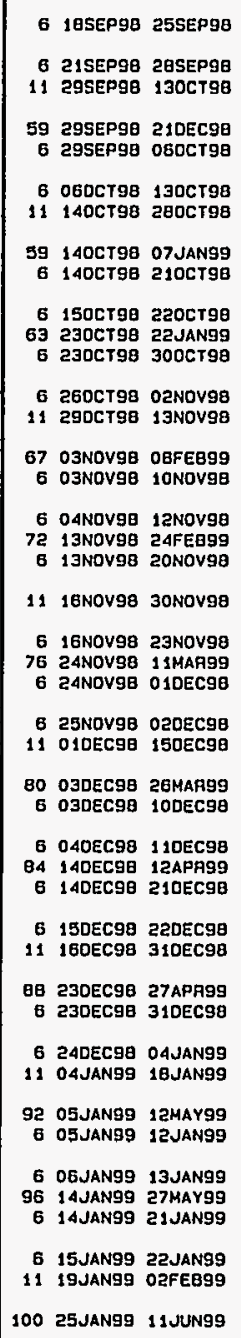 & PTamonow & & & & 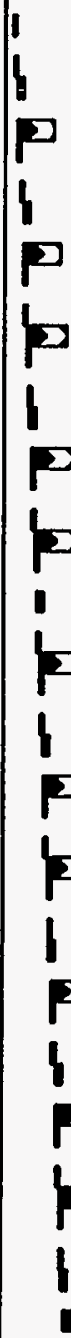 & & & \\
\hline 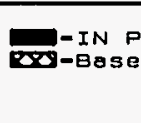 & $\begin{array}{l}\text { egend } \\
\text { POGPESS } \\
\text { Ine }\end{array}$ & & & & & & & 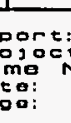 & 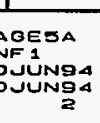 & \\
\hline
\end{tabular}


SNF/SNM Consolidation Schedule

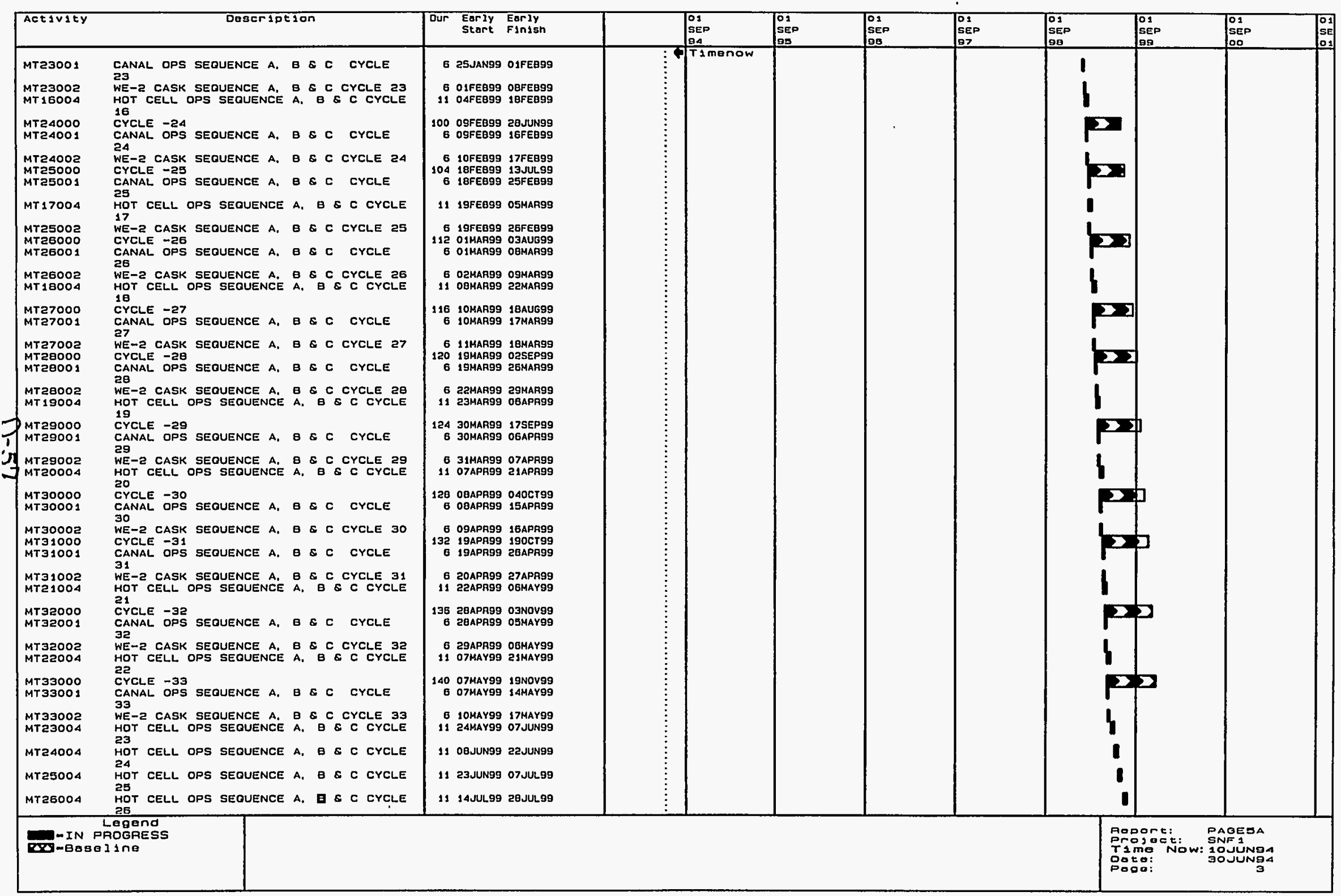




\section{SNF/SNM Consolidation Schedule}

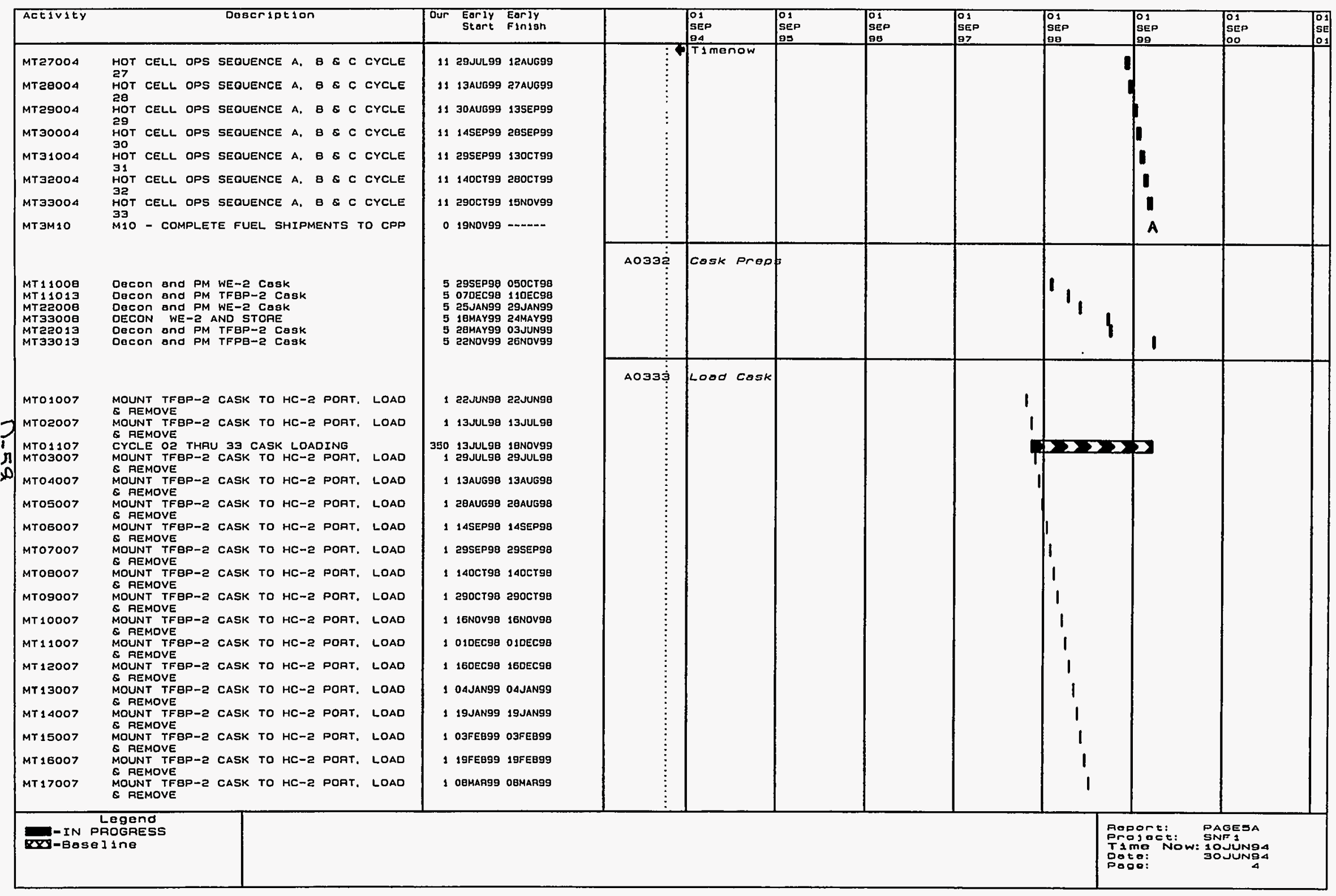


SNF/SNM Consolidation Schedule

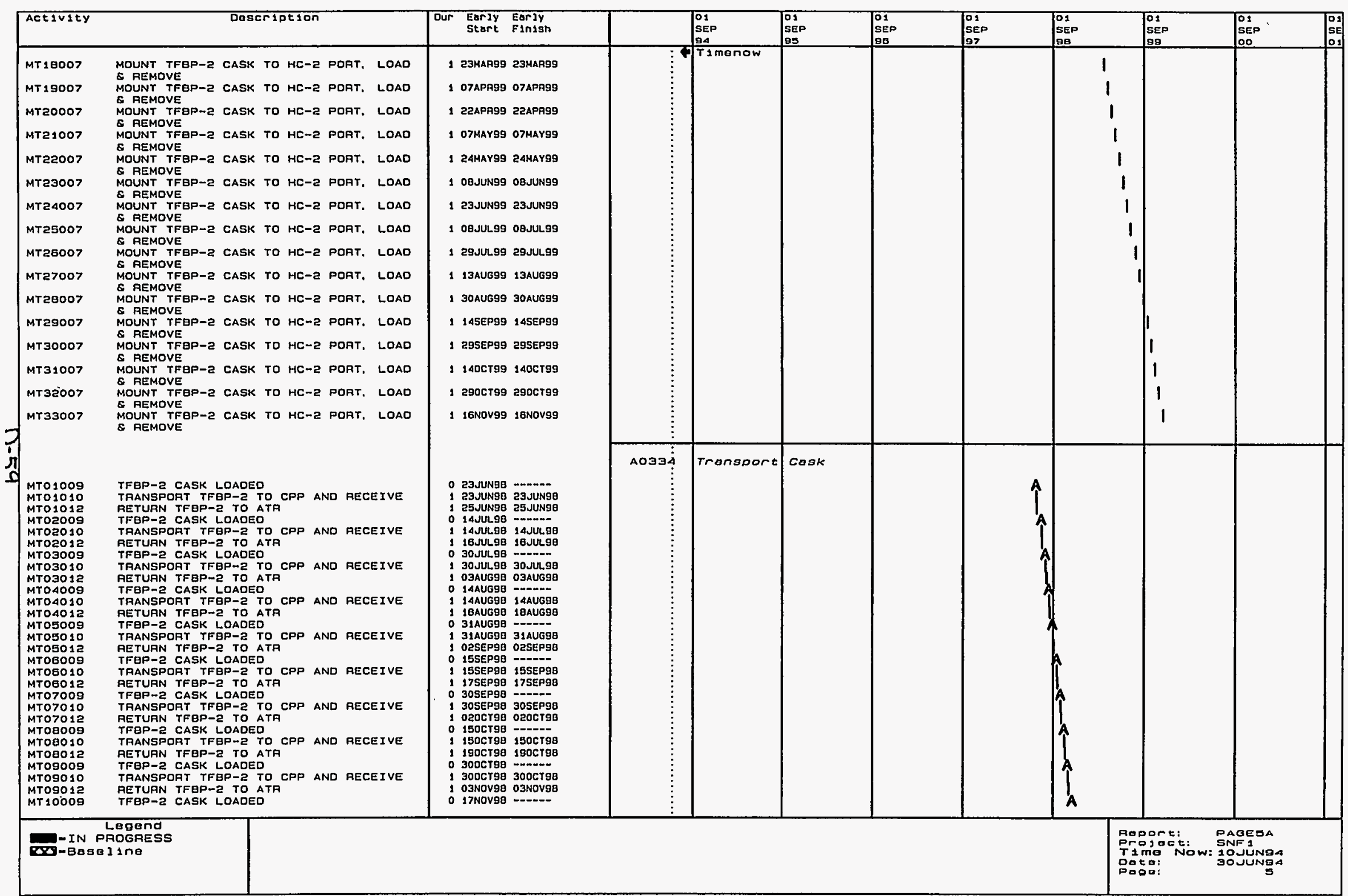


SNF/SNM Consolidation Schedule

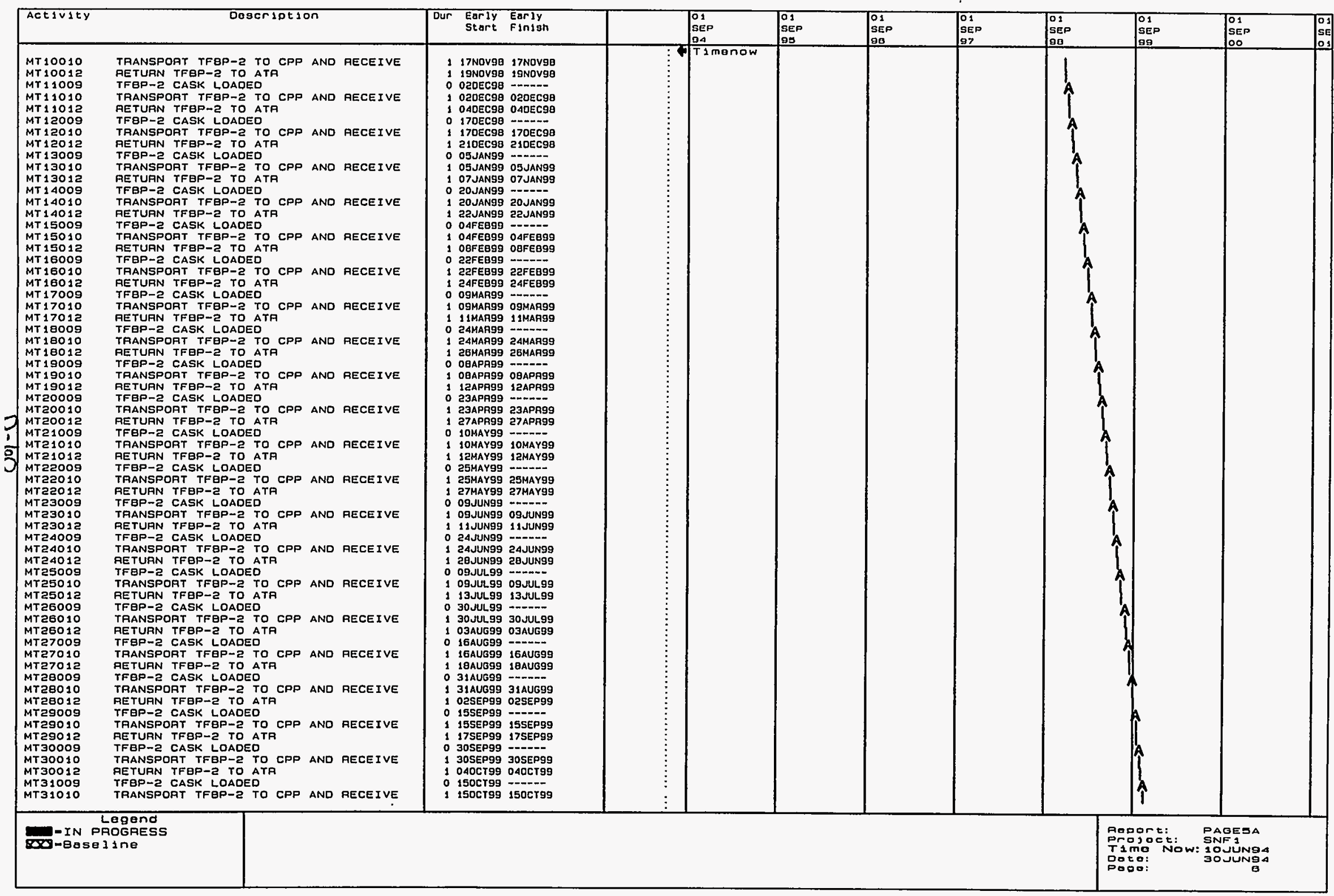


SNF/SNM Consolidation Schedule

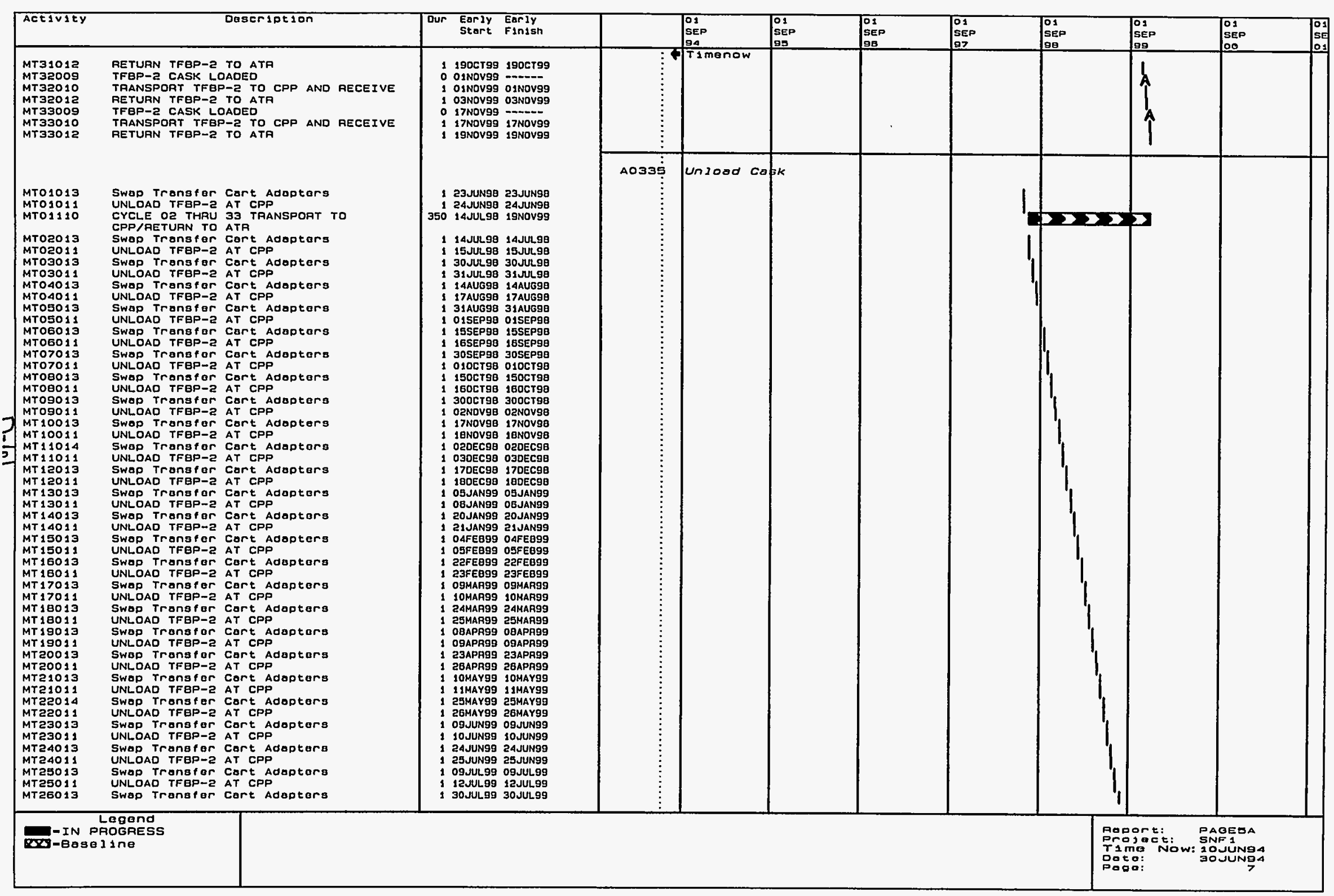


SNF/SNM Consolidation Schedule

Spent Nuclear Fugd

Consolioation

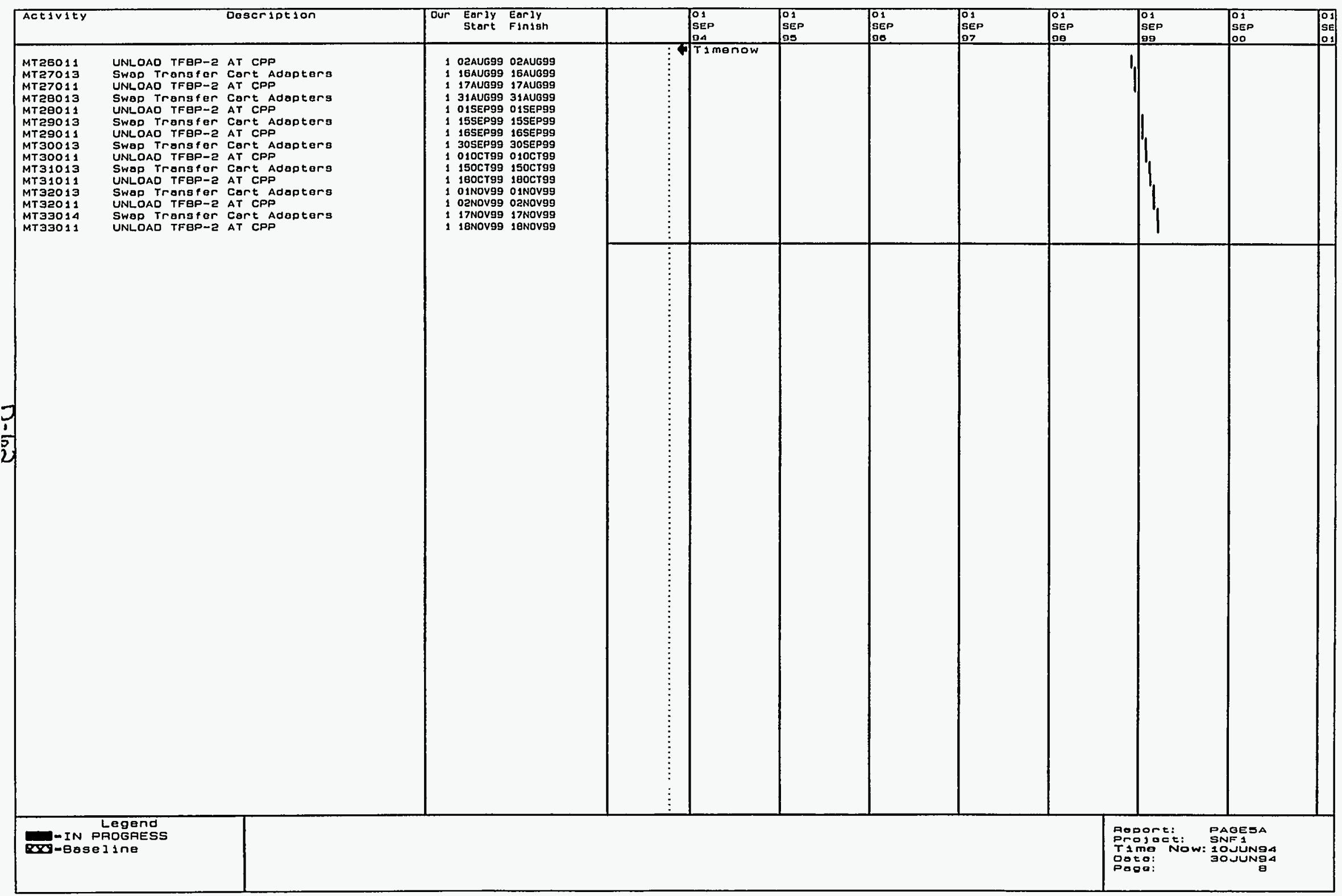




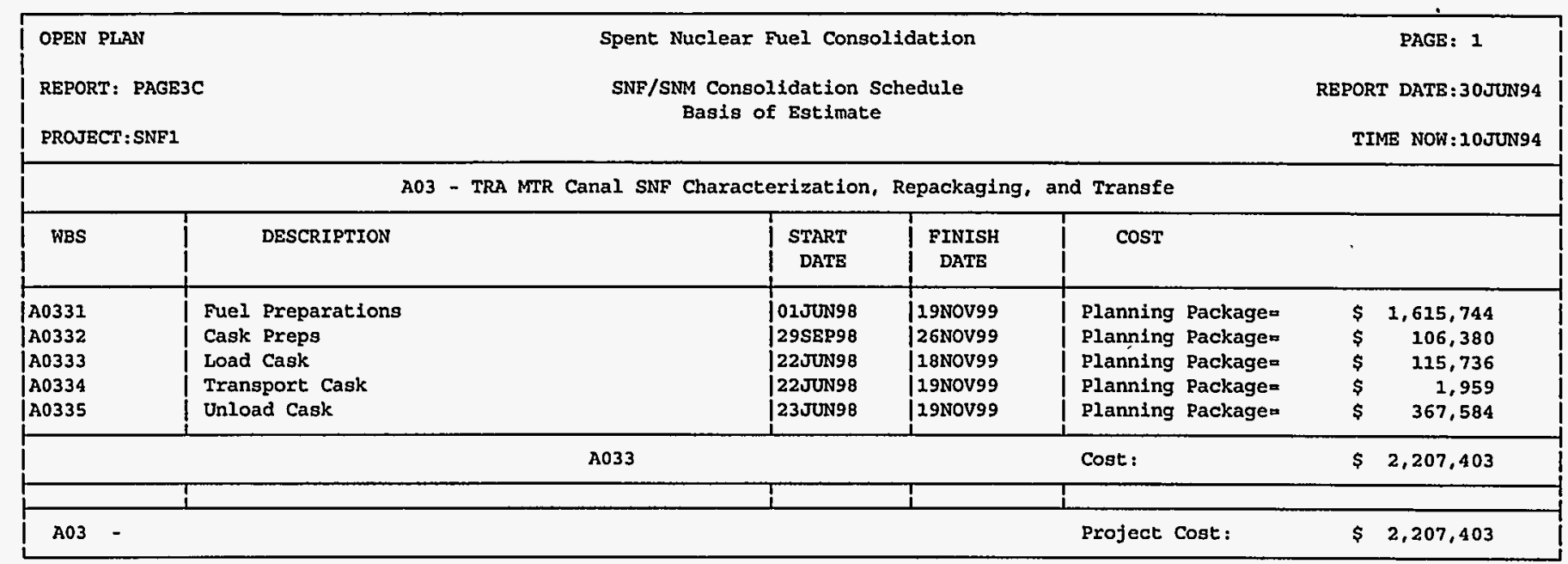

$\frac{p}{0}$ 


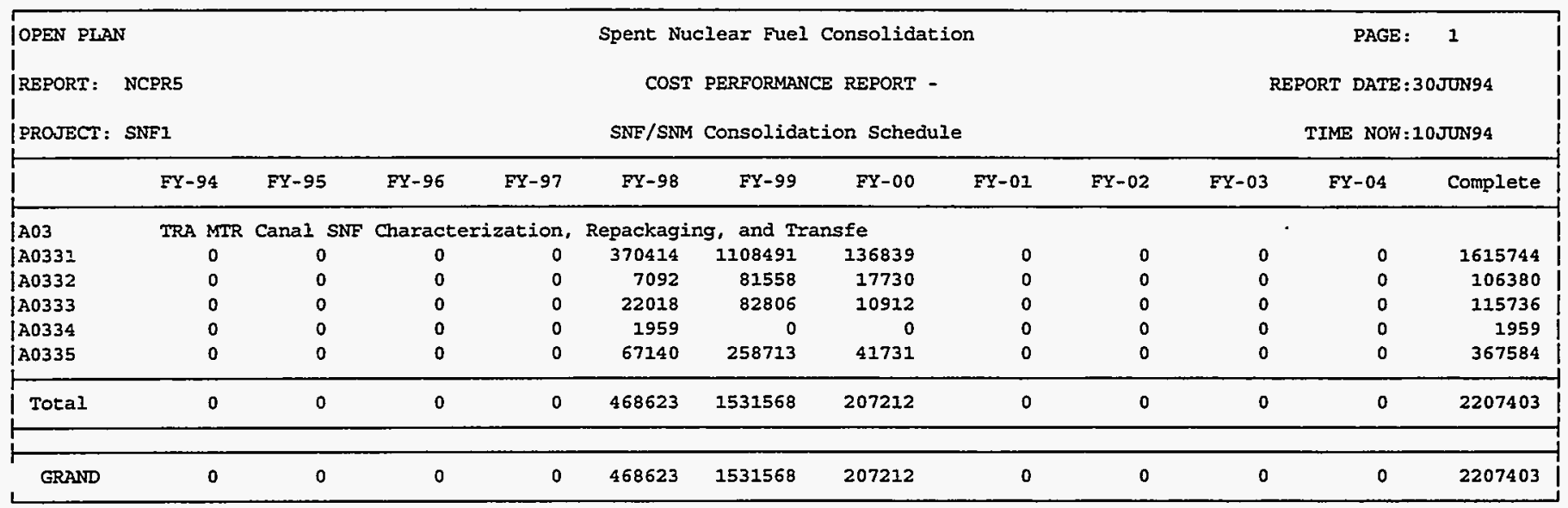




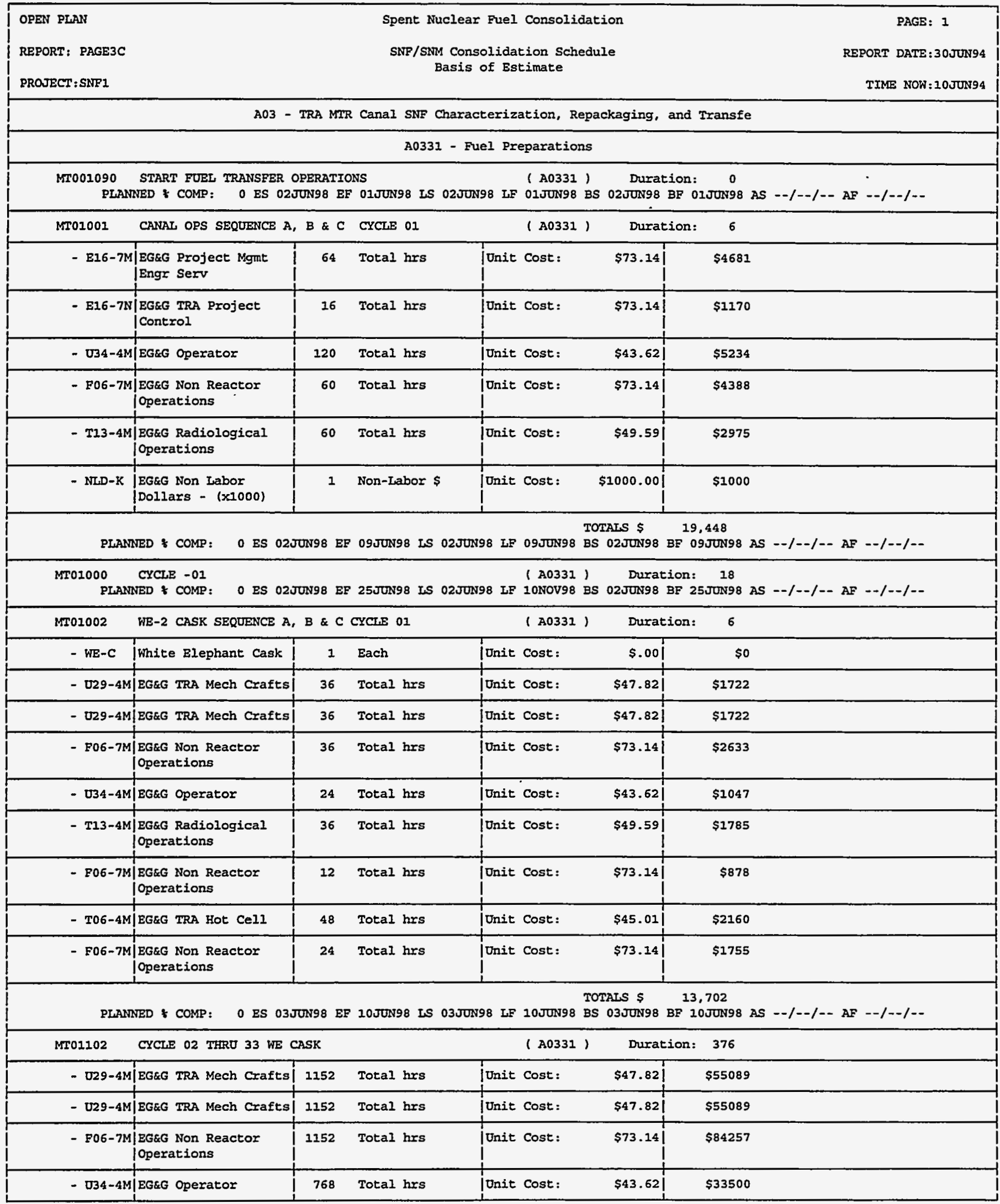




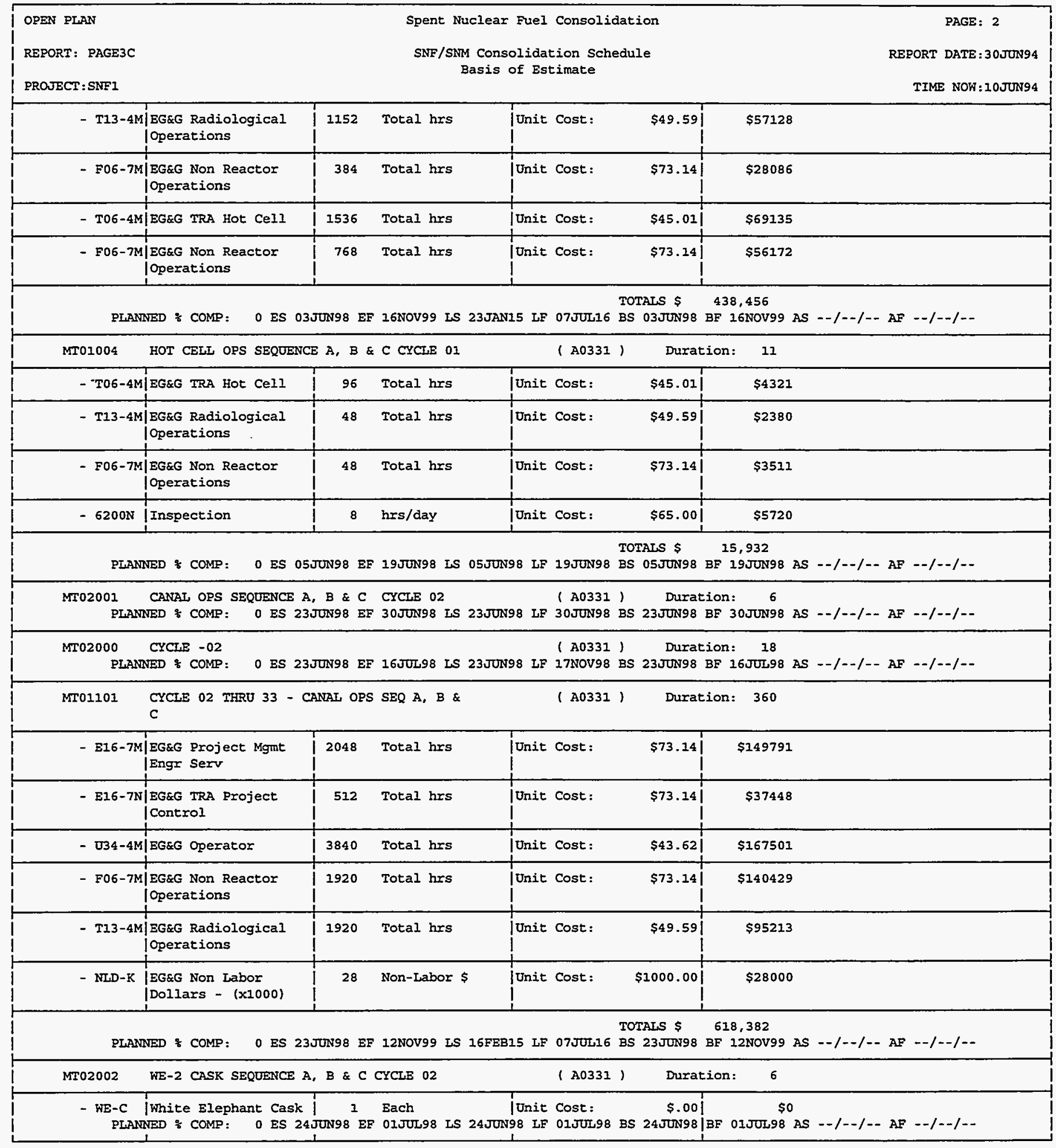




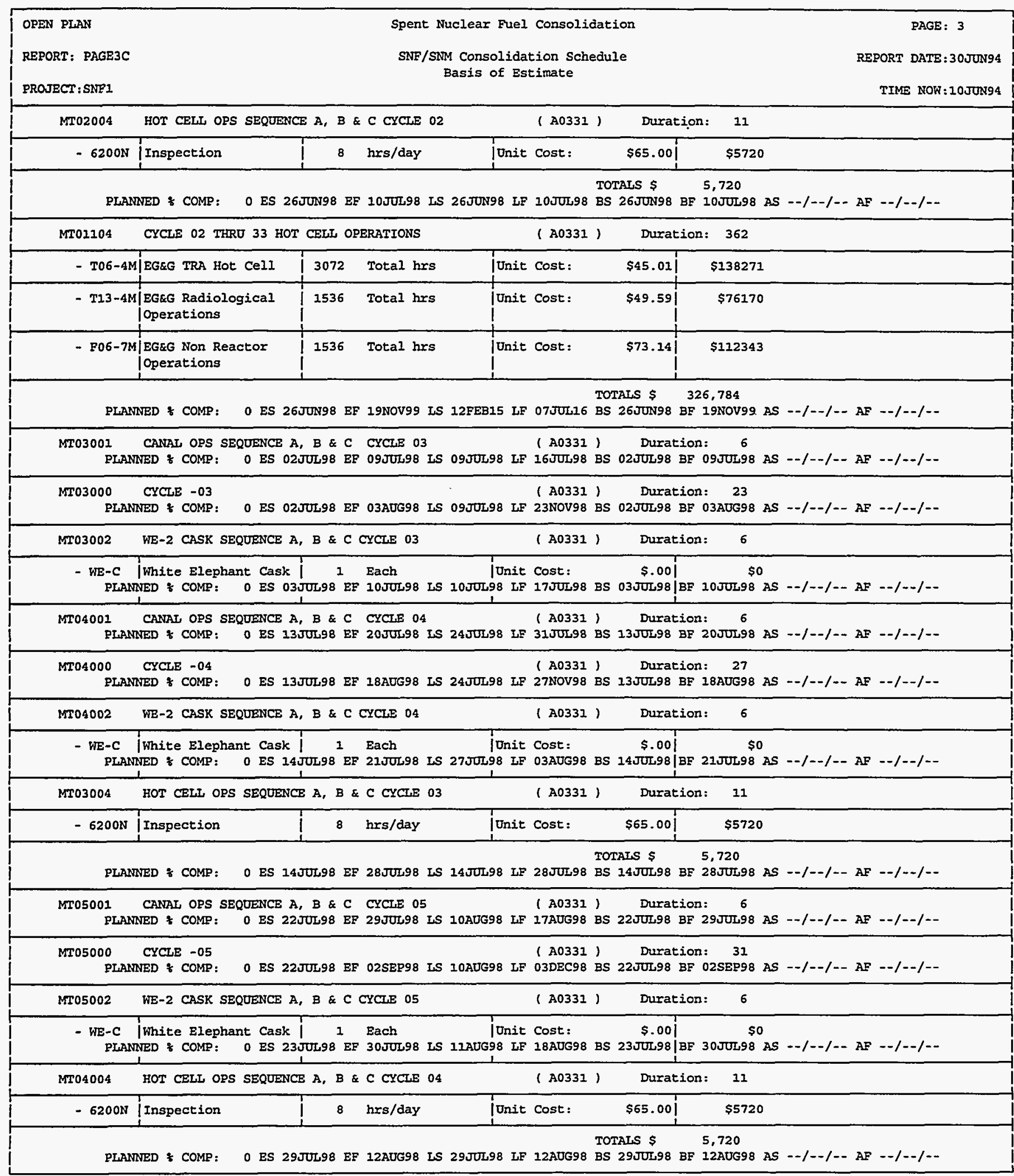




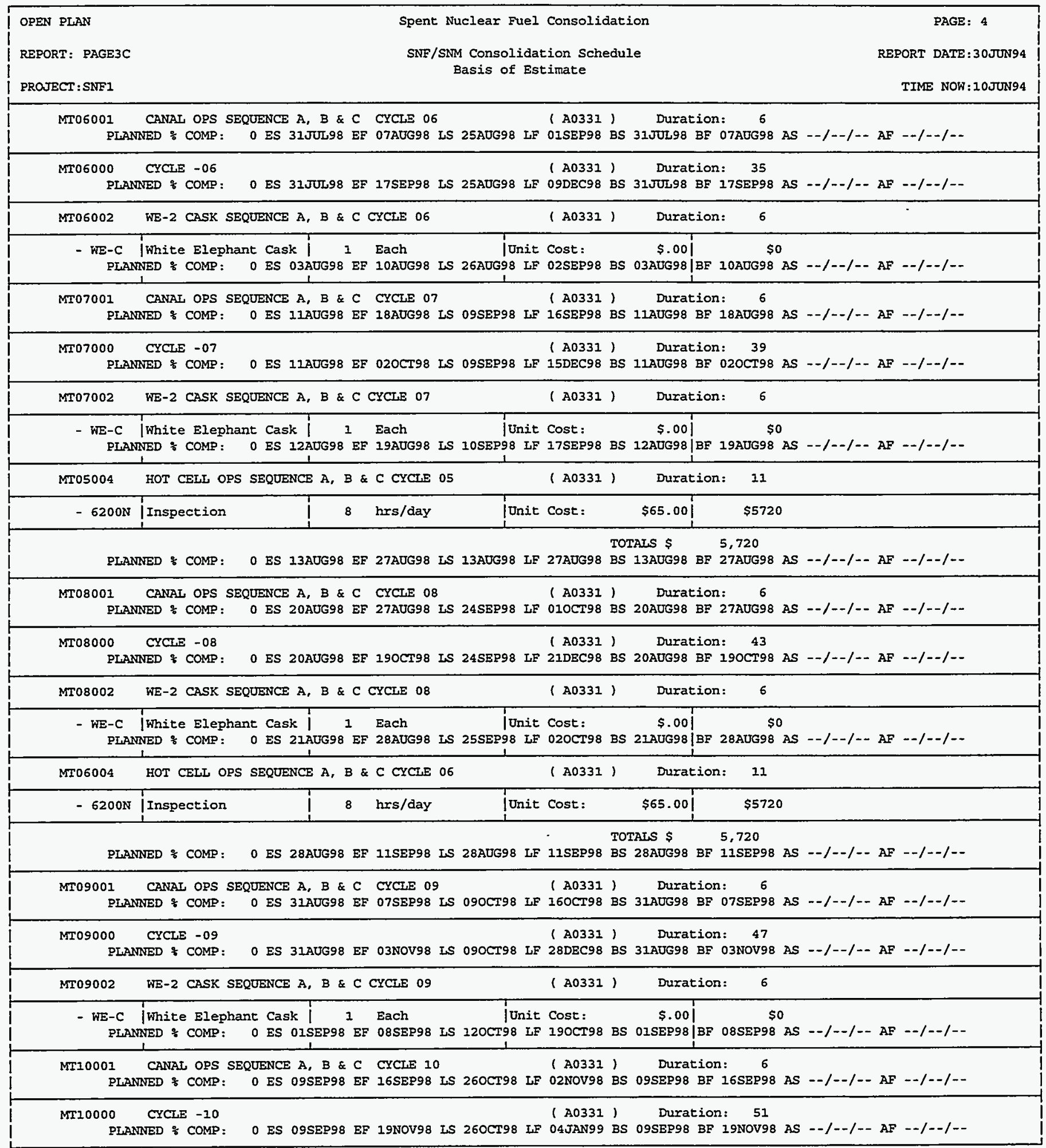




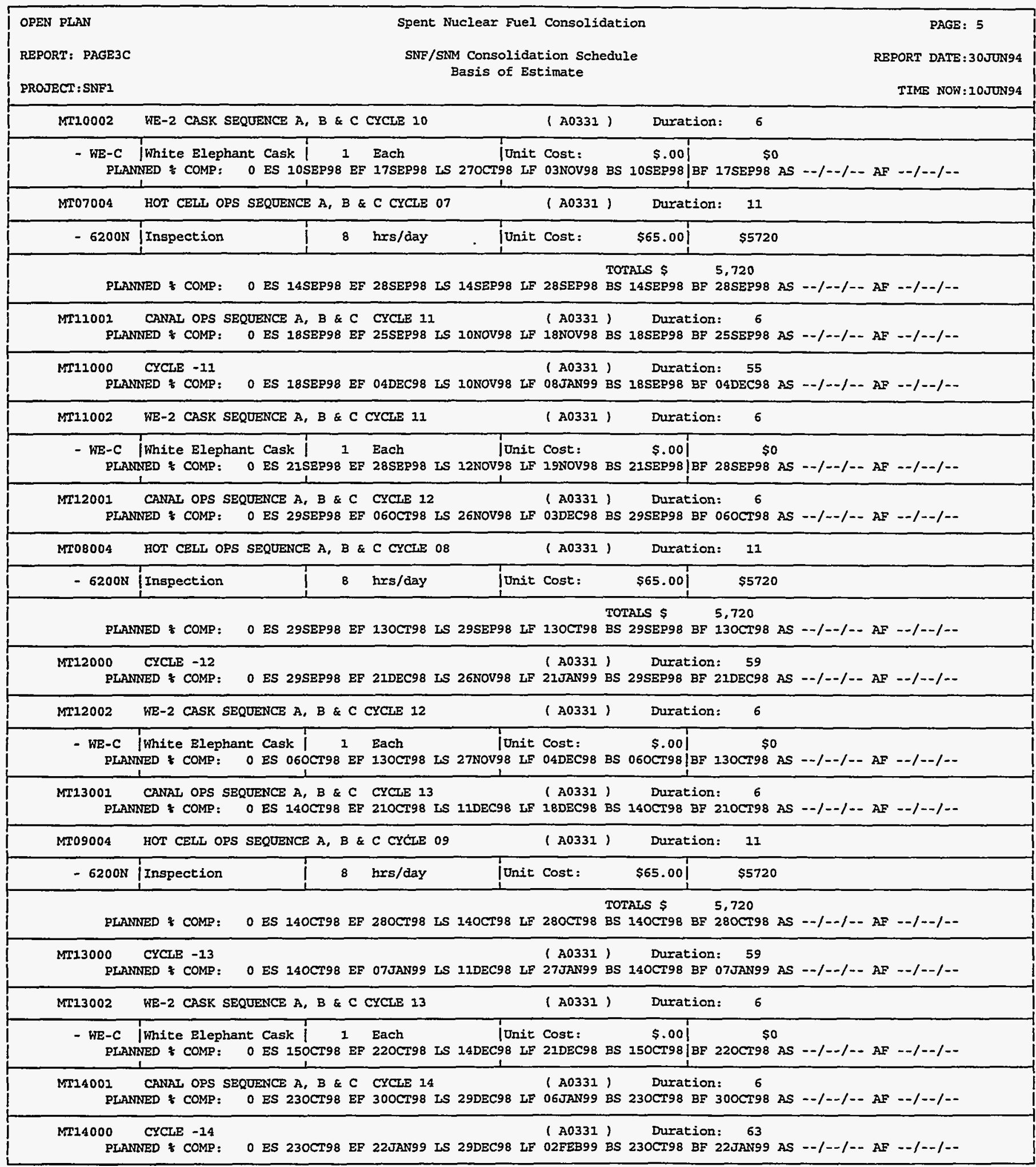




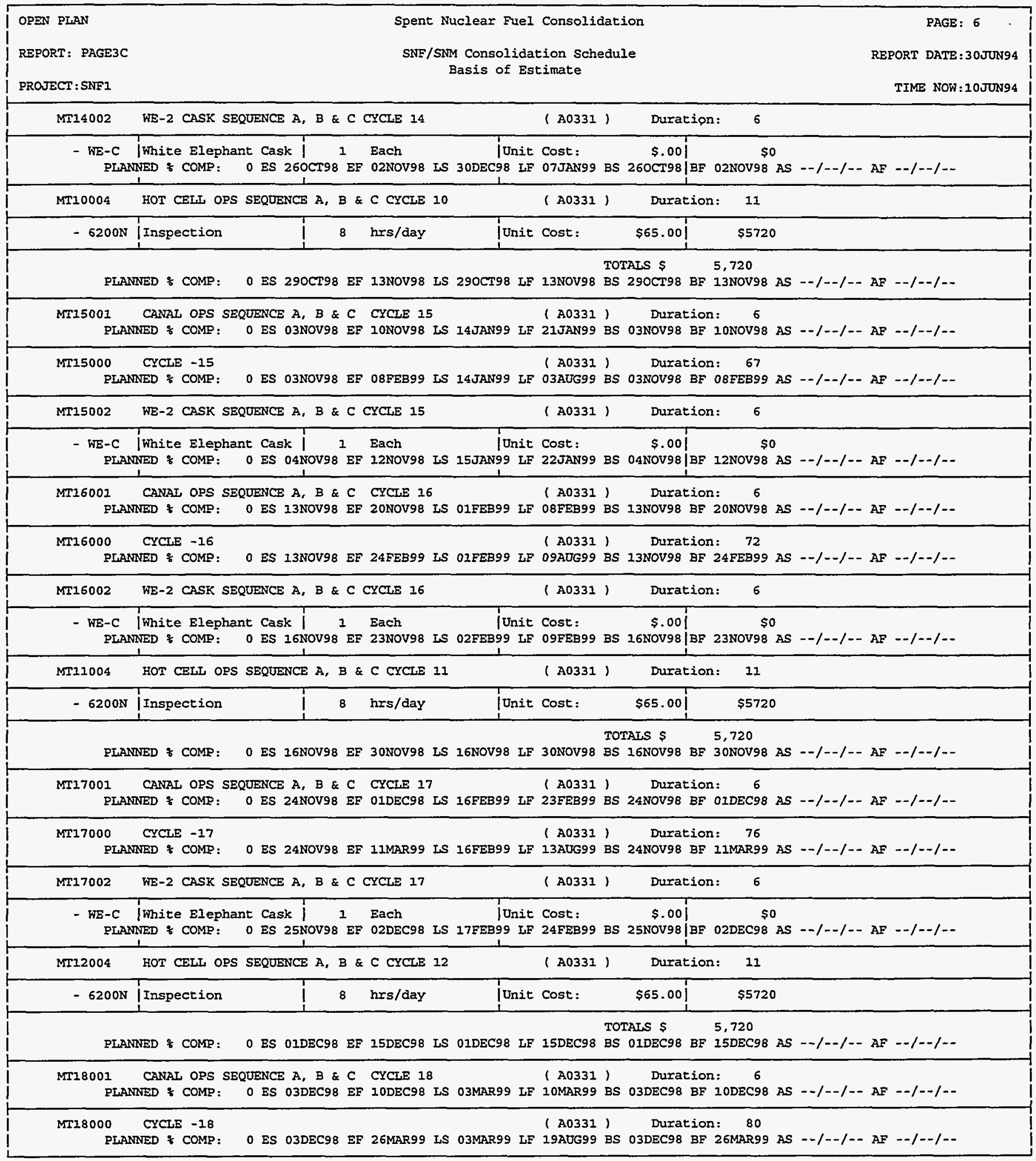




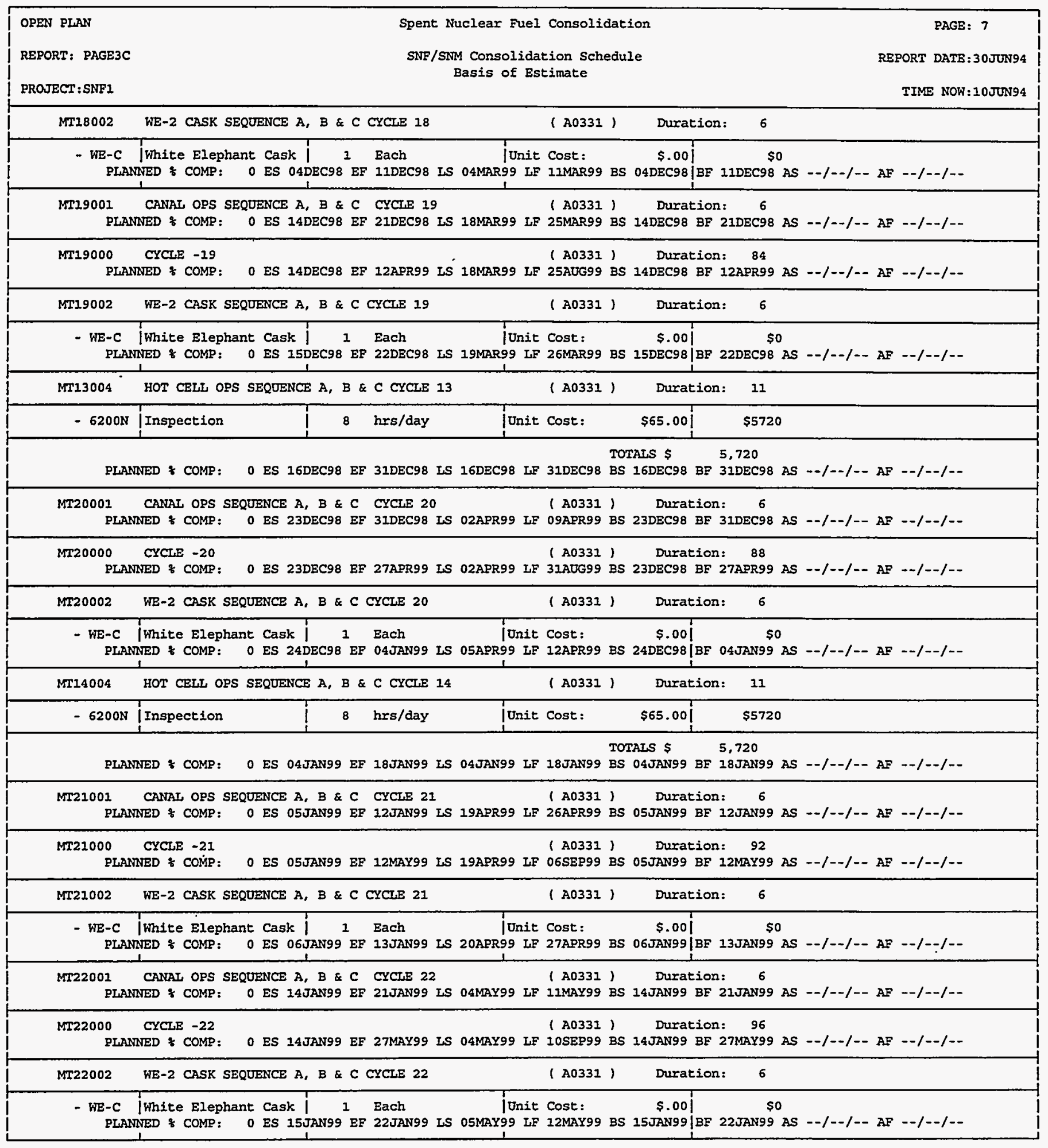




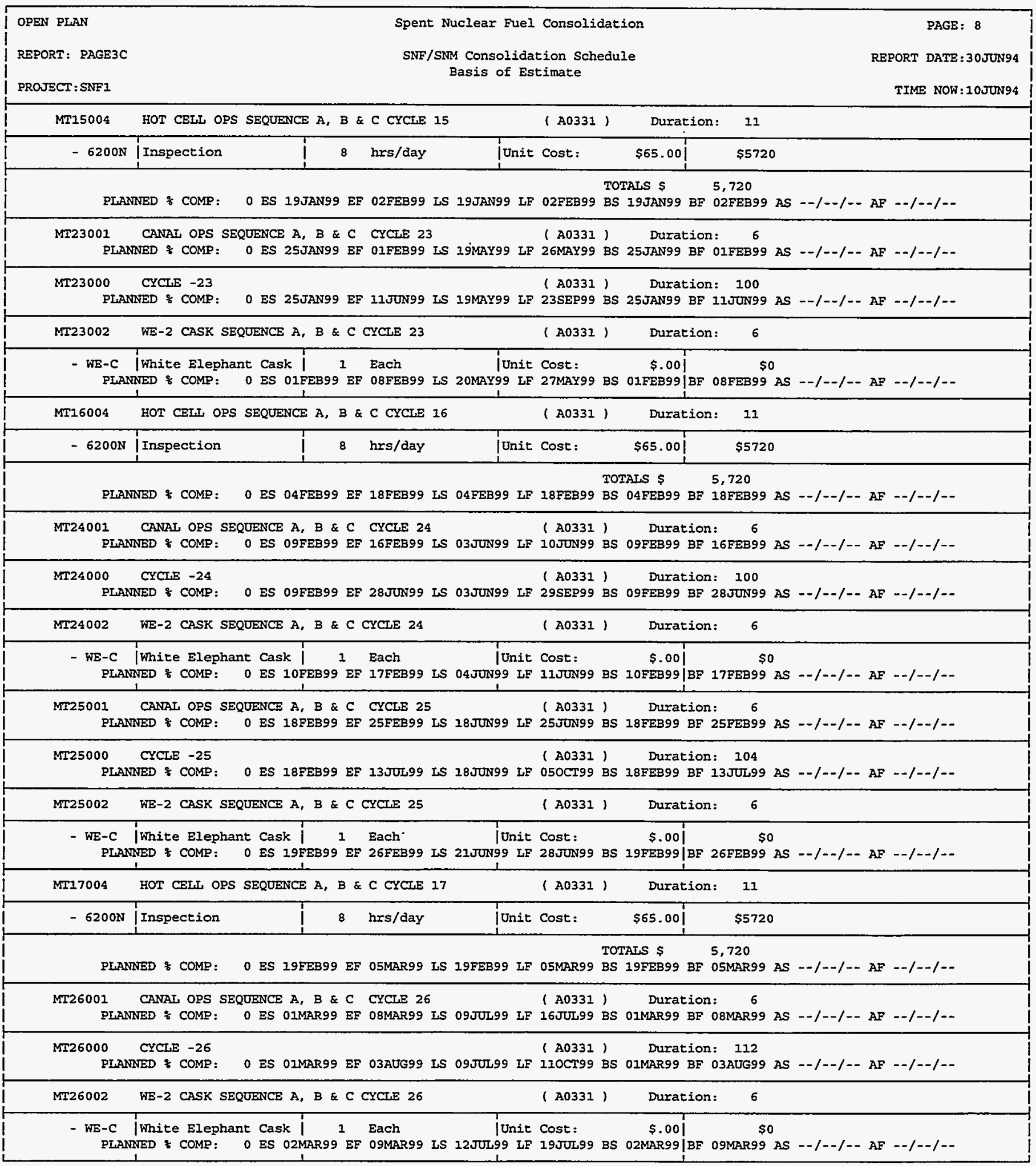




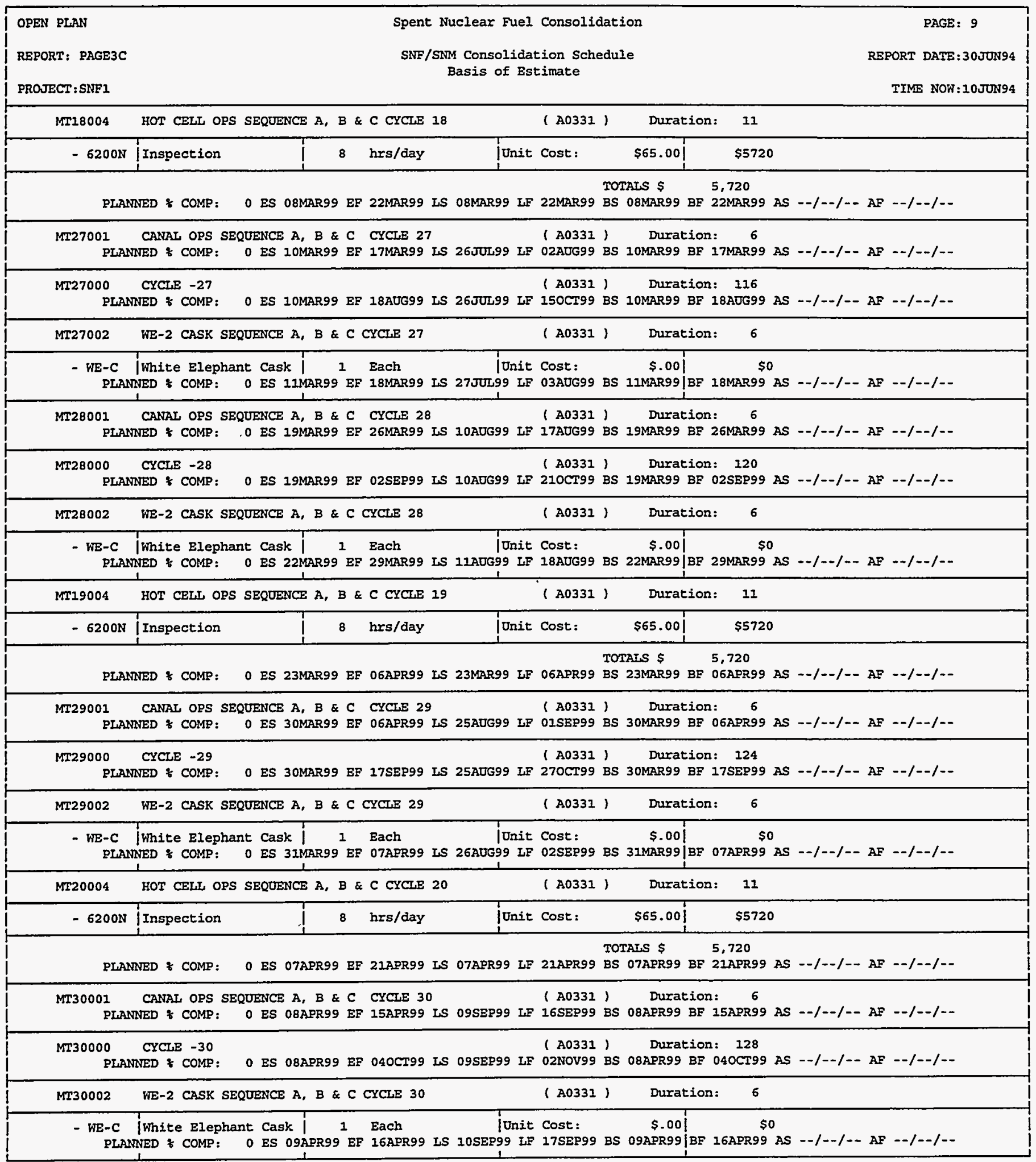

\section{73}




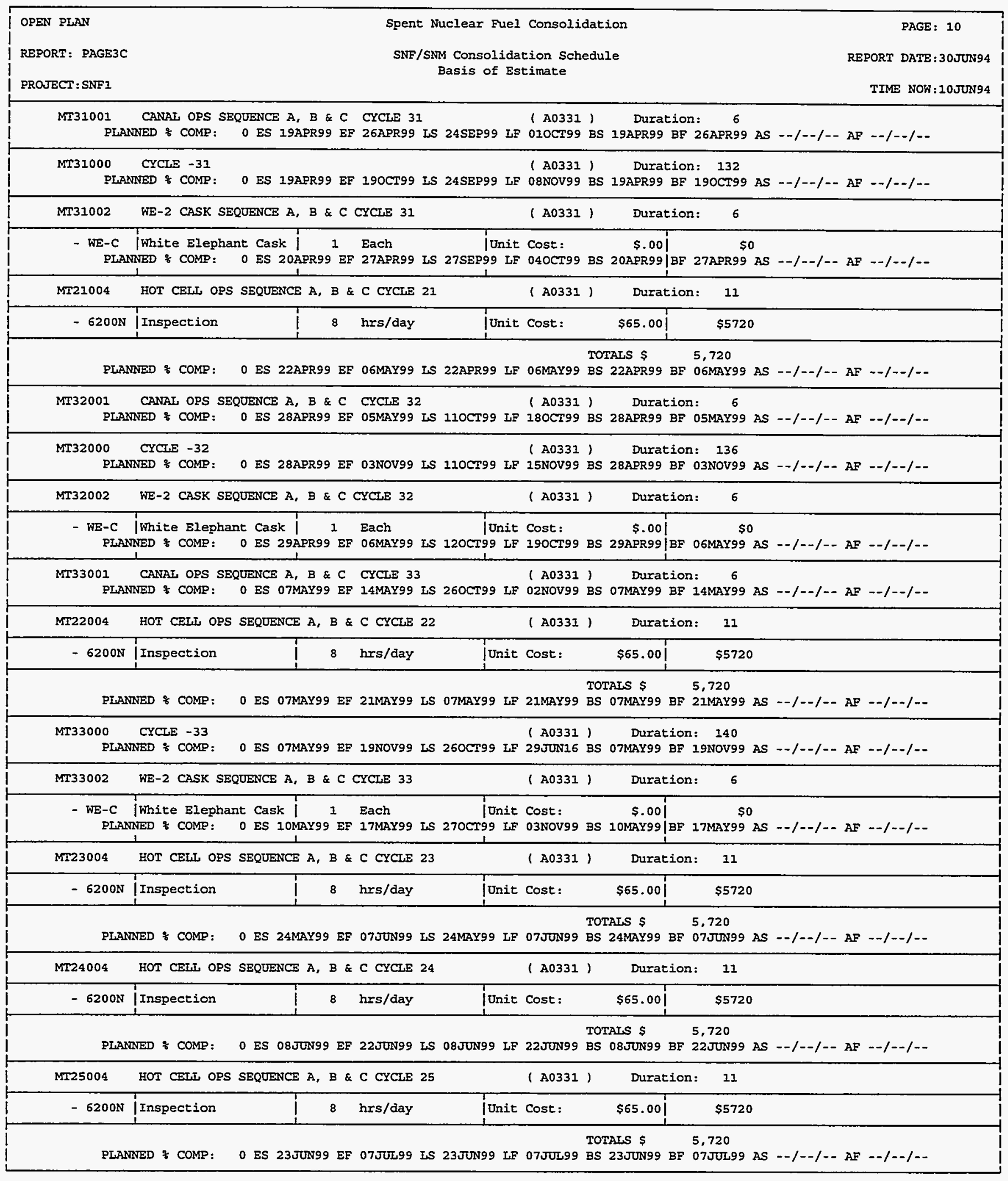




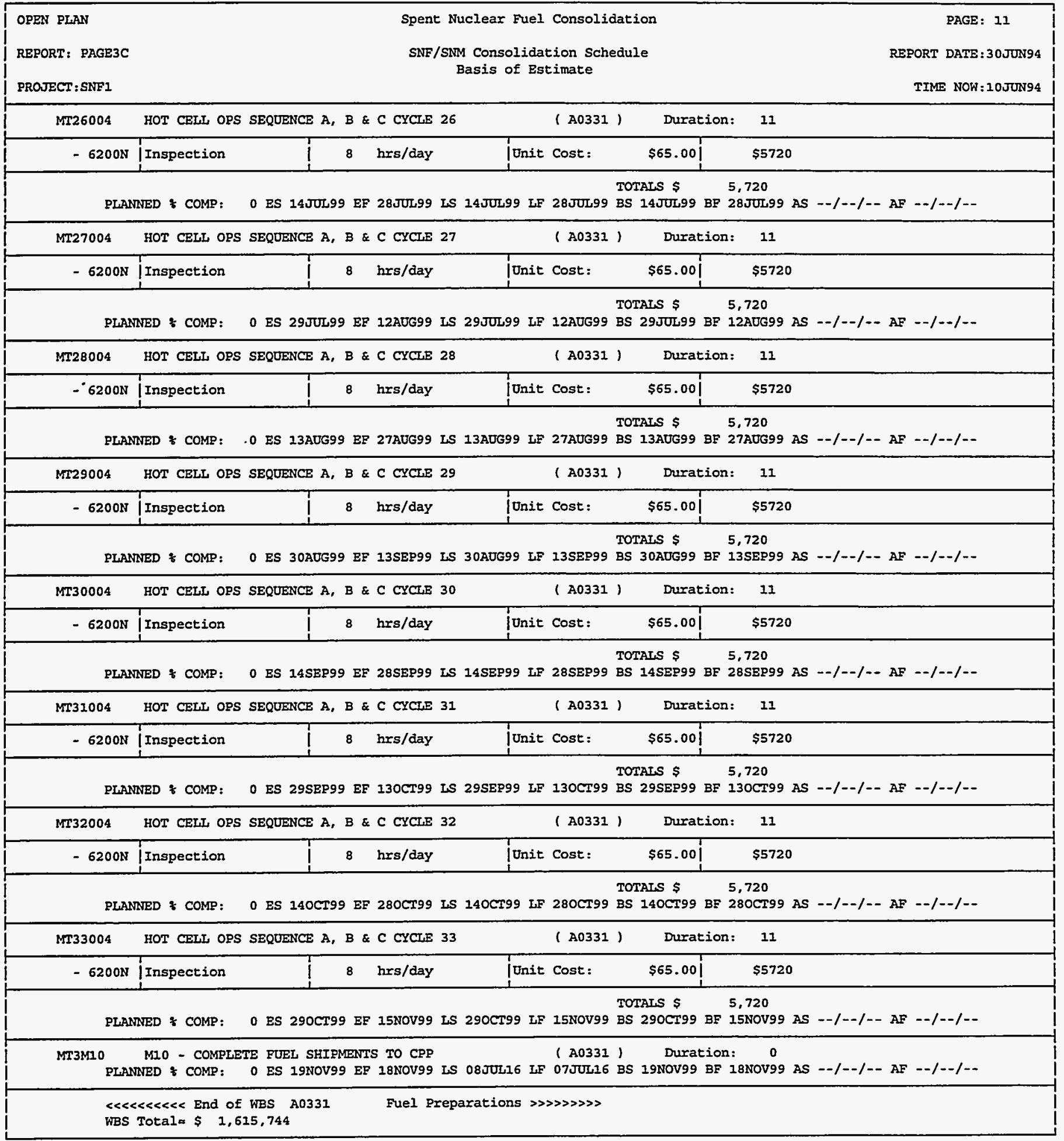

\section{D-75}




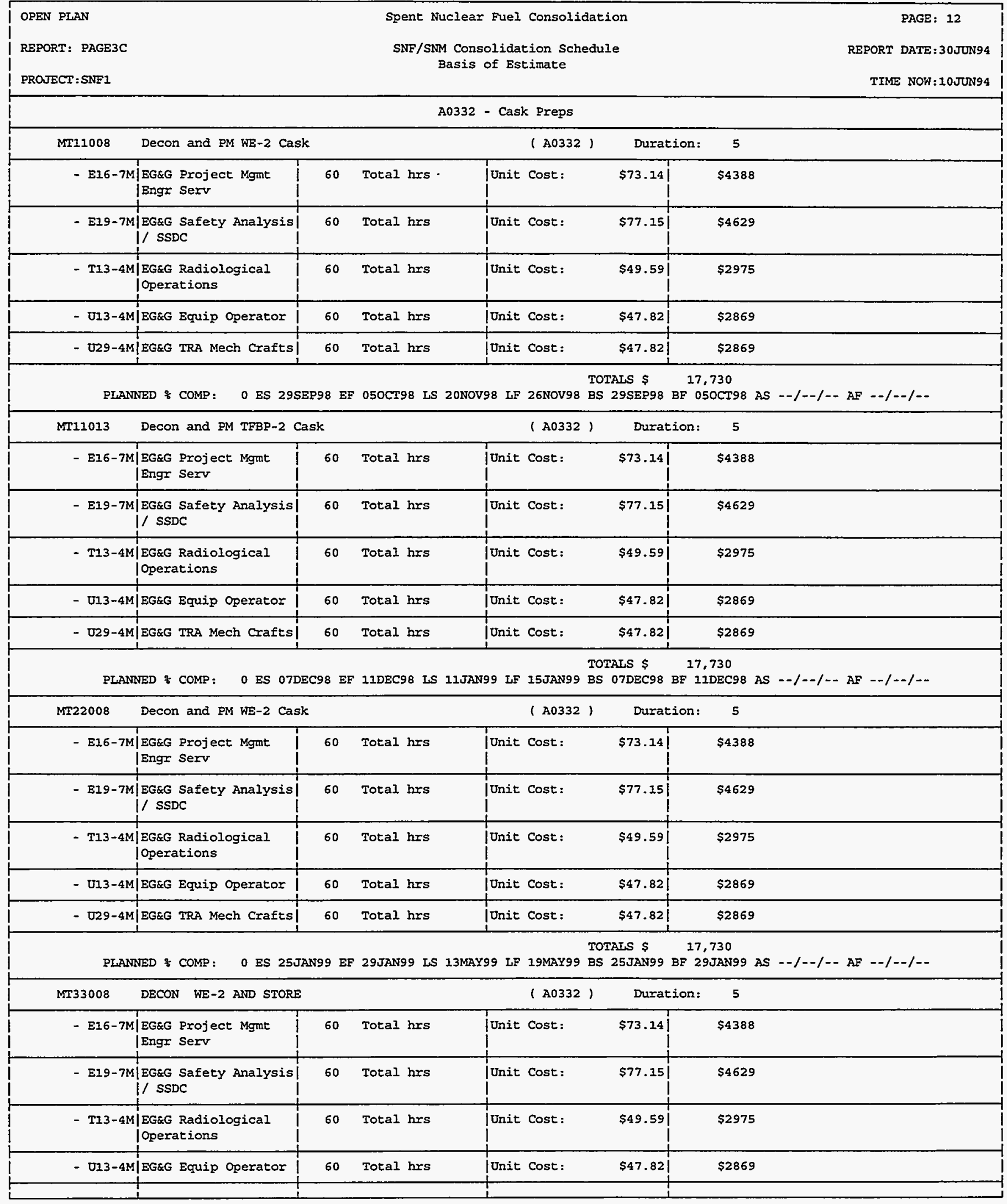




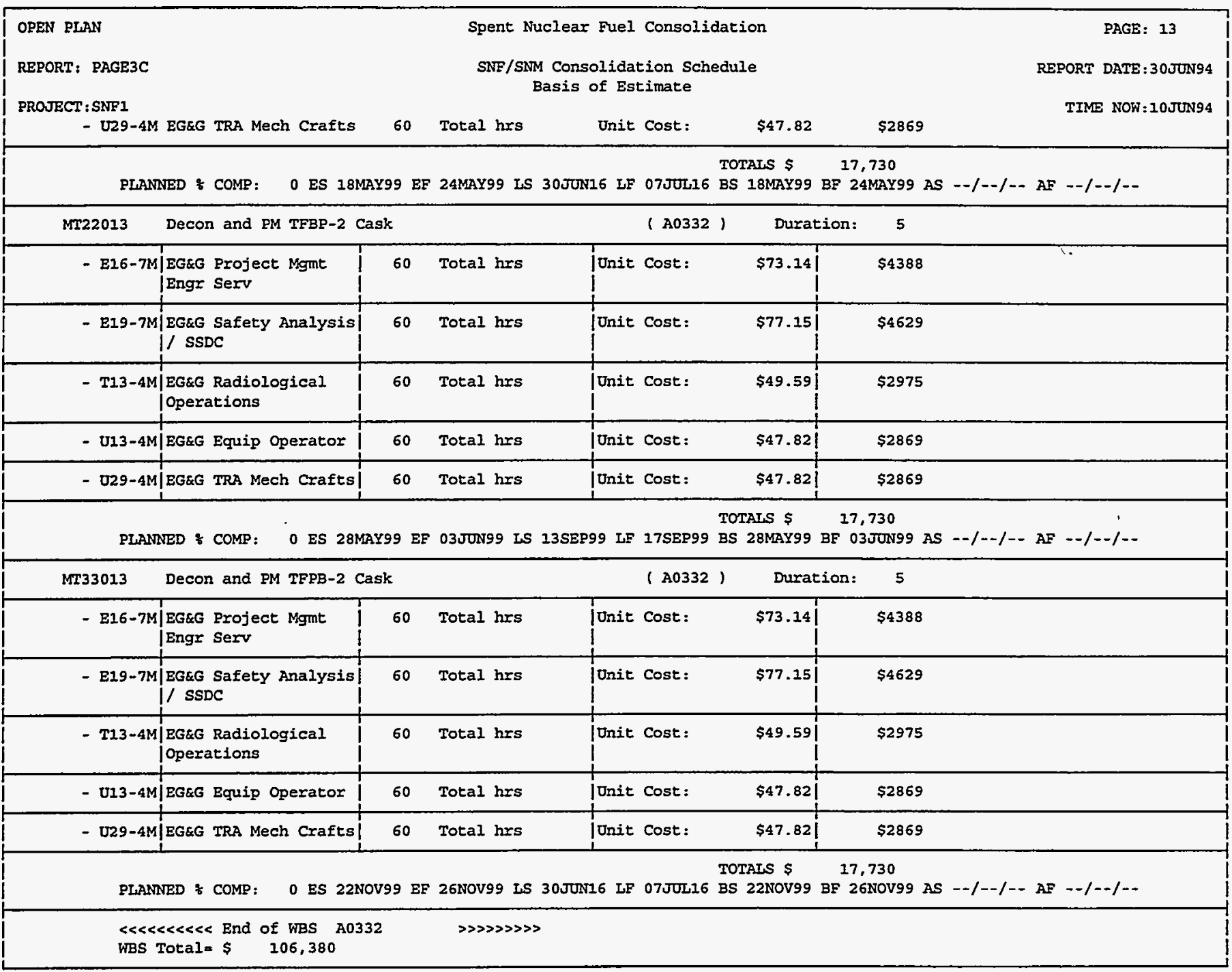




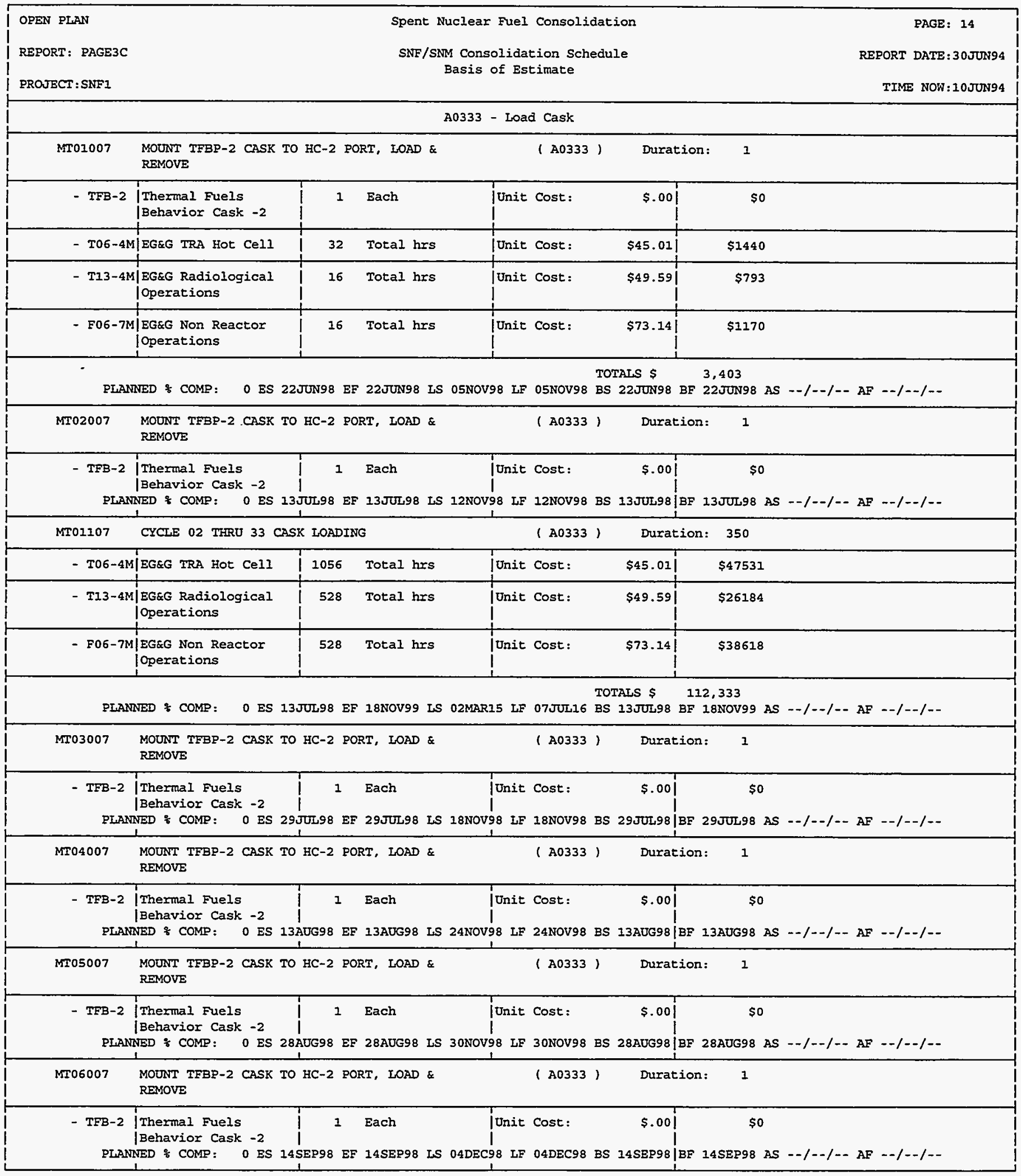




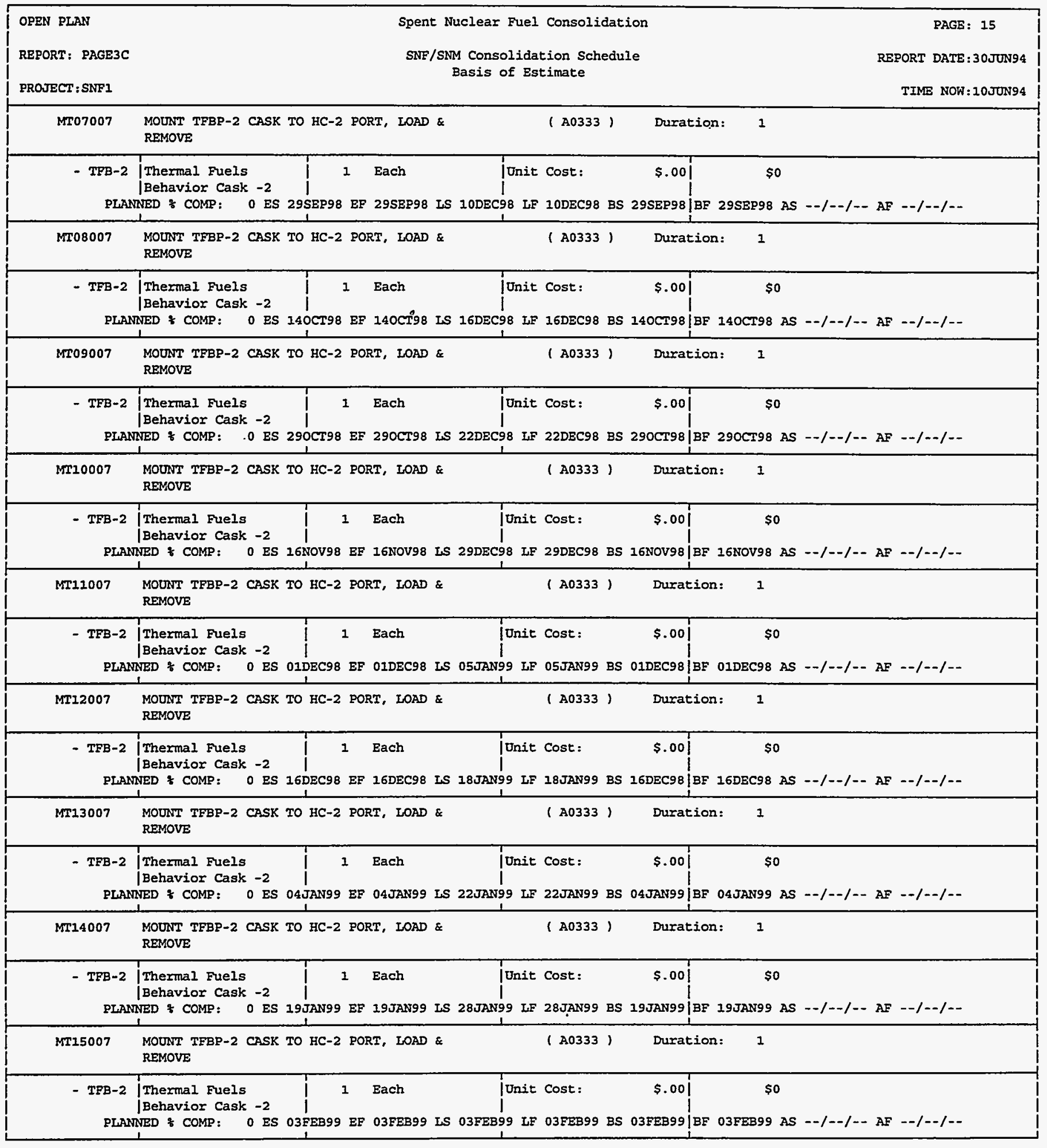




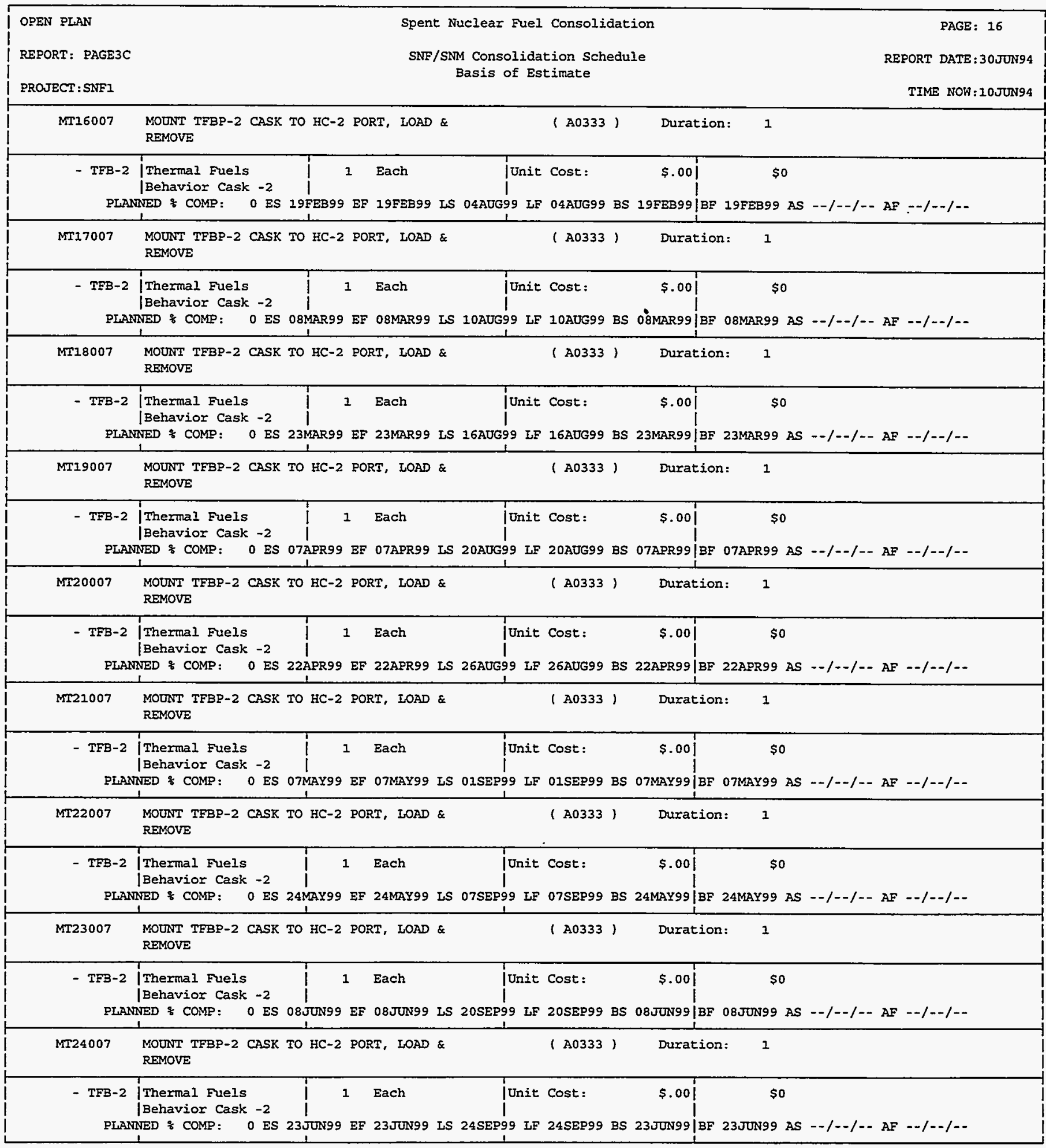




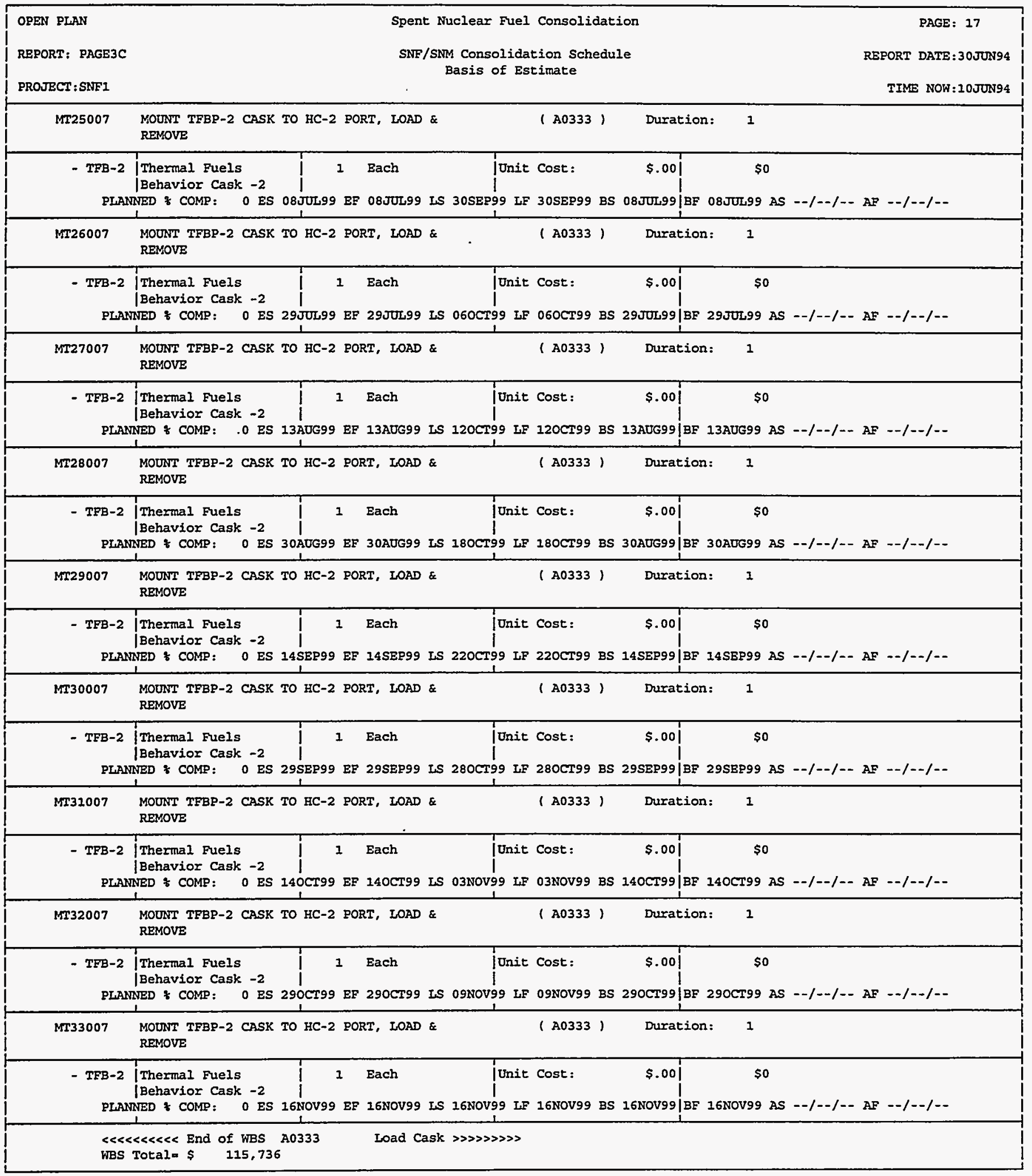

\section{$D-81$}




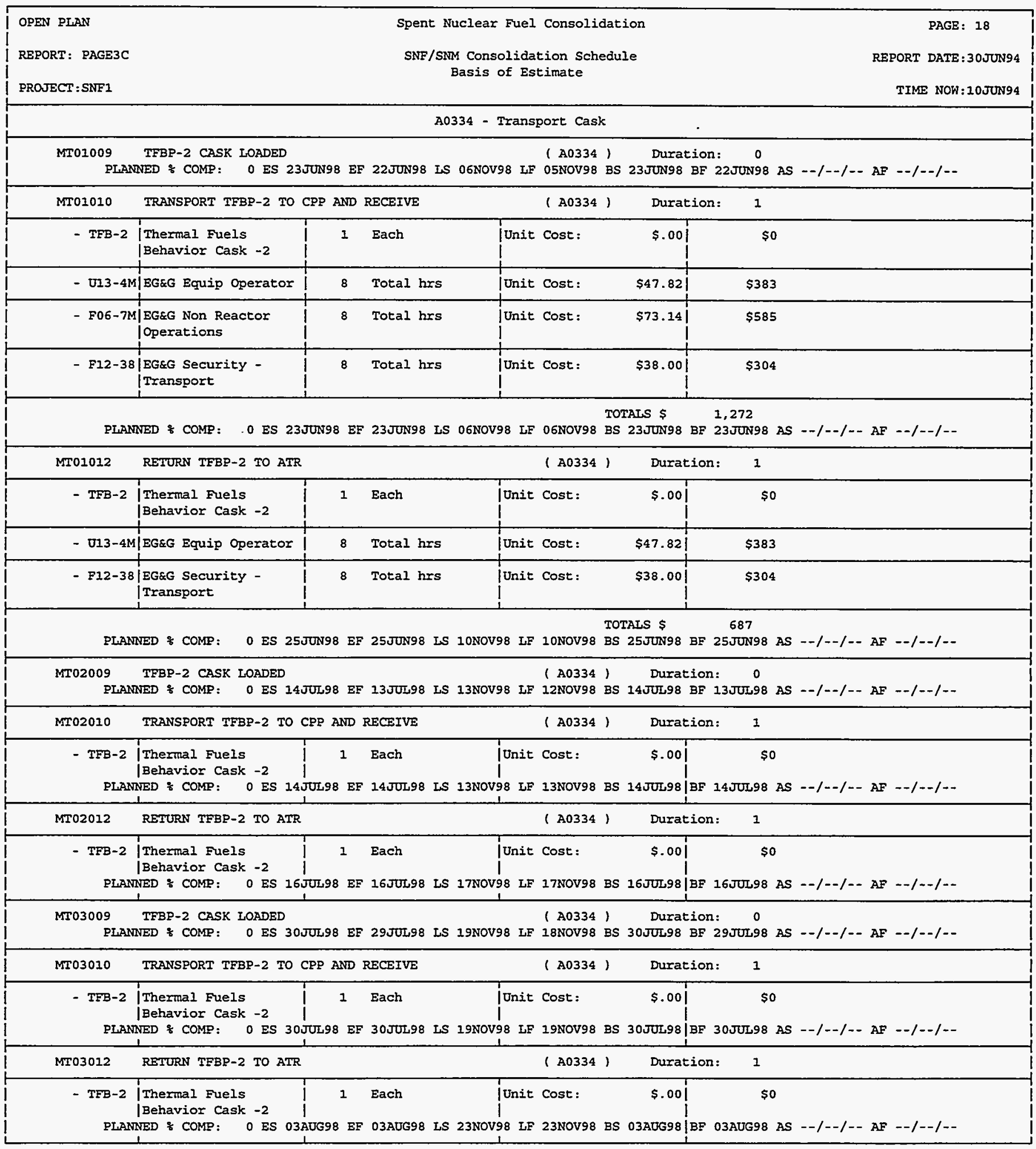




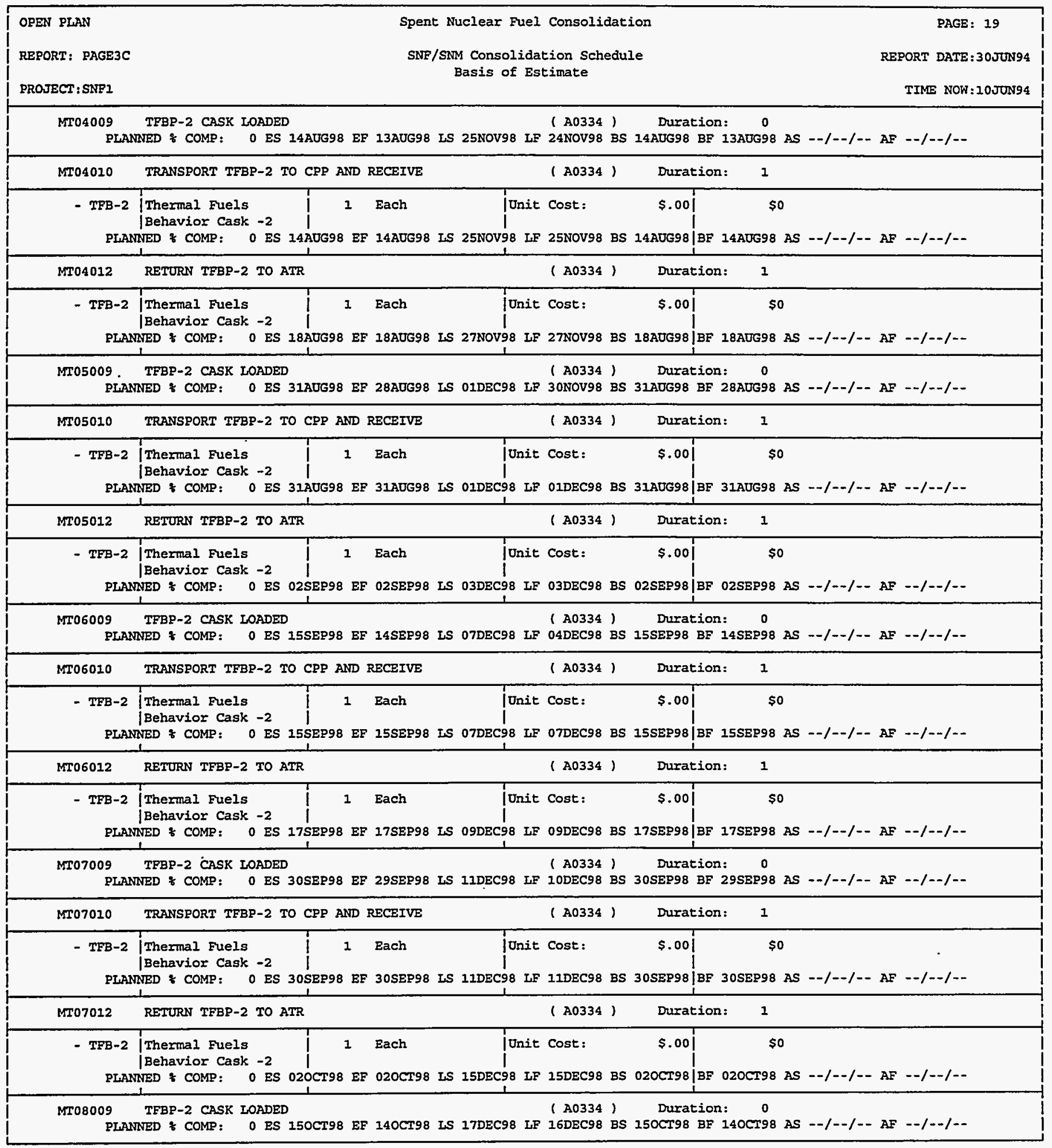




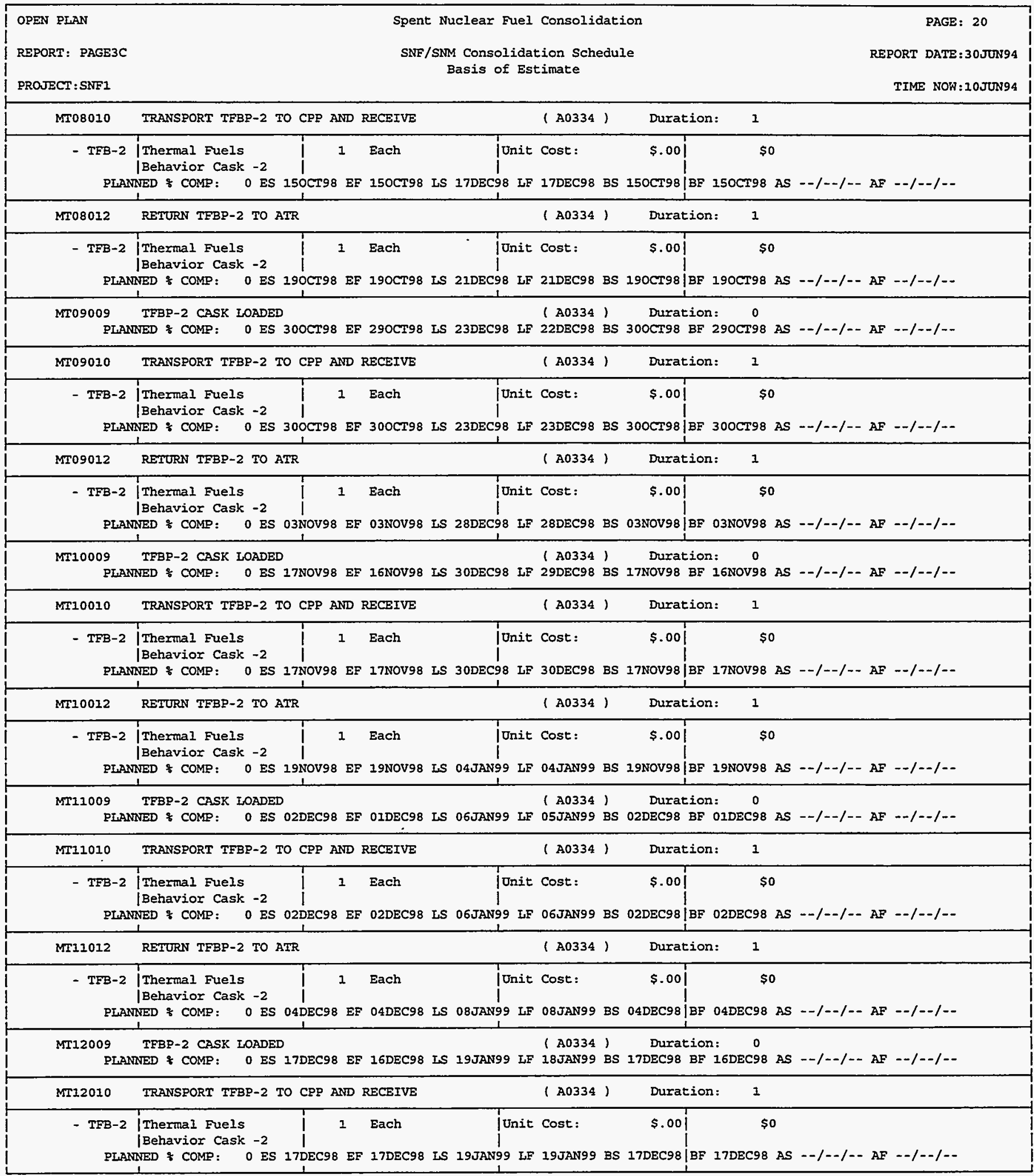

$$
D-84
$$




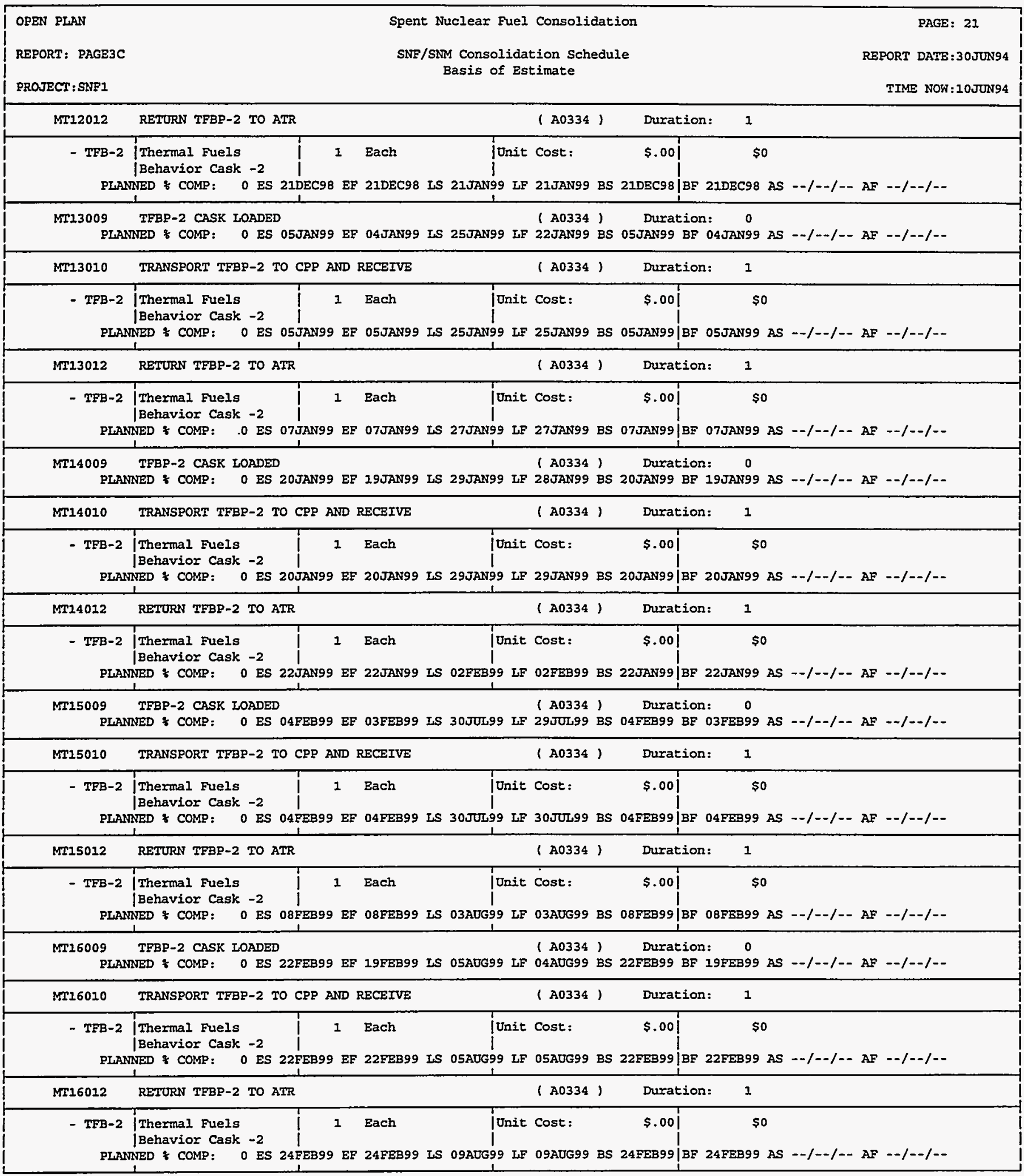




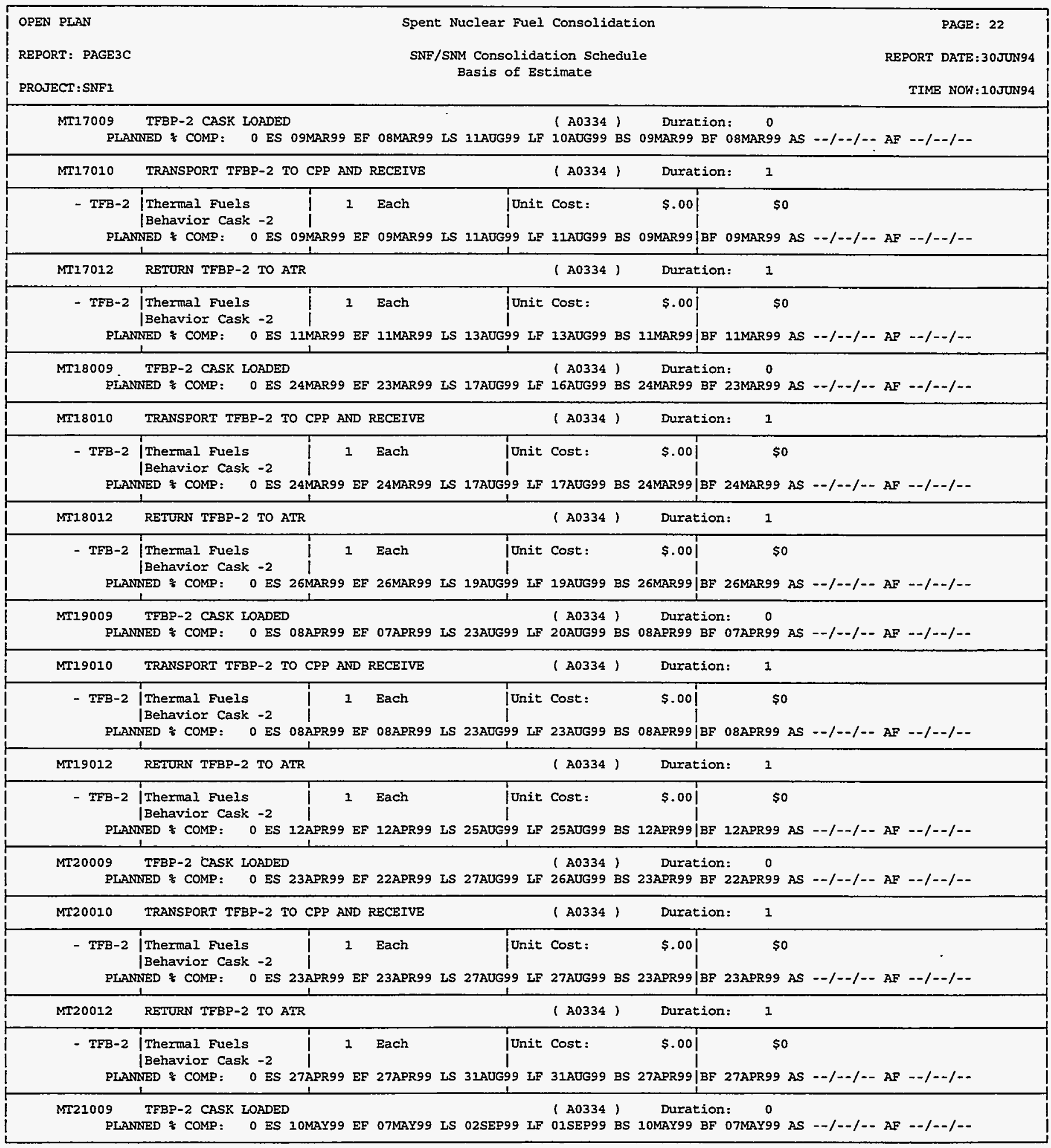




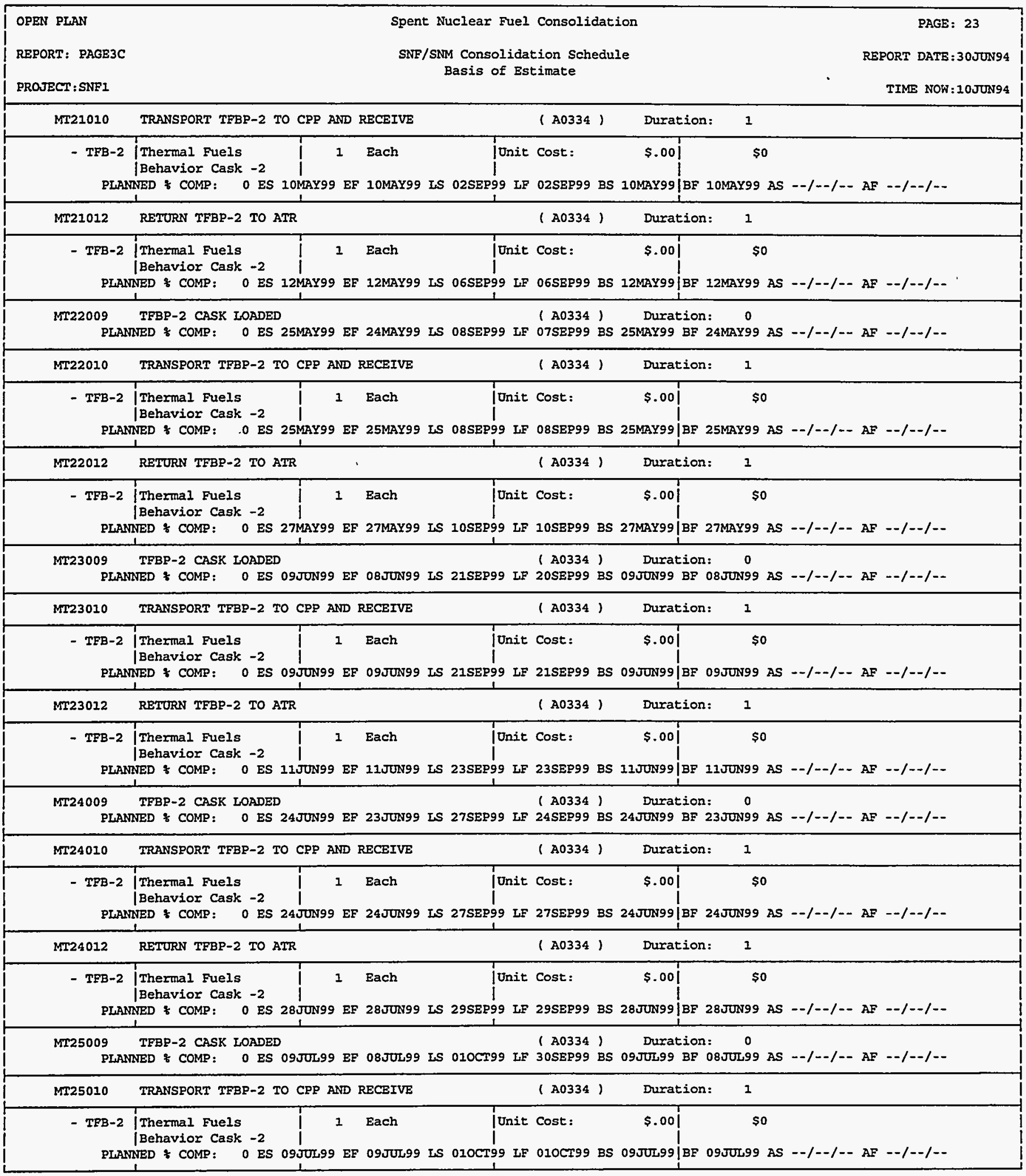




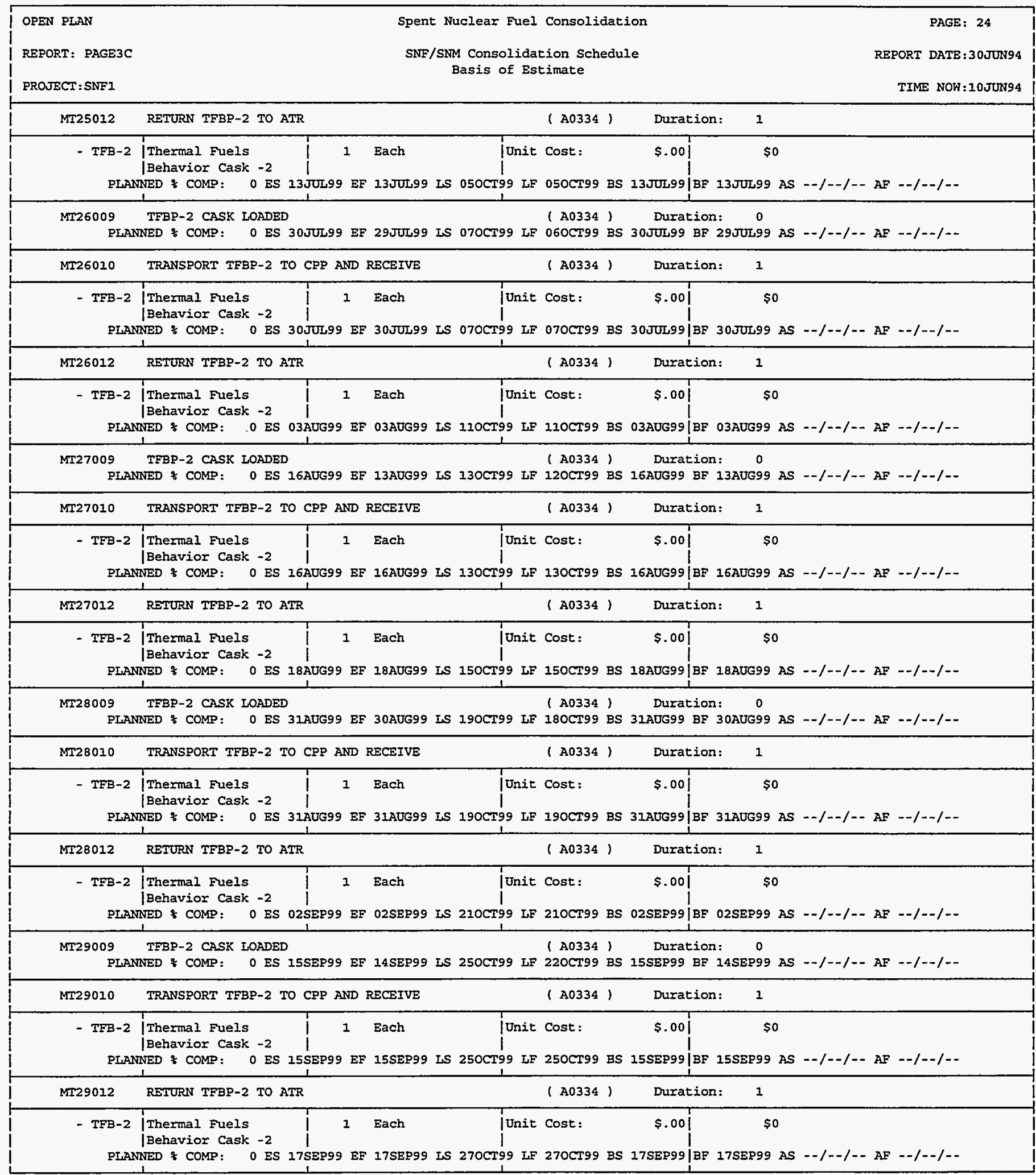




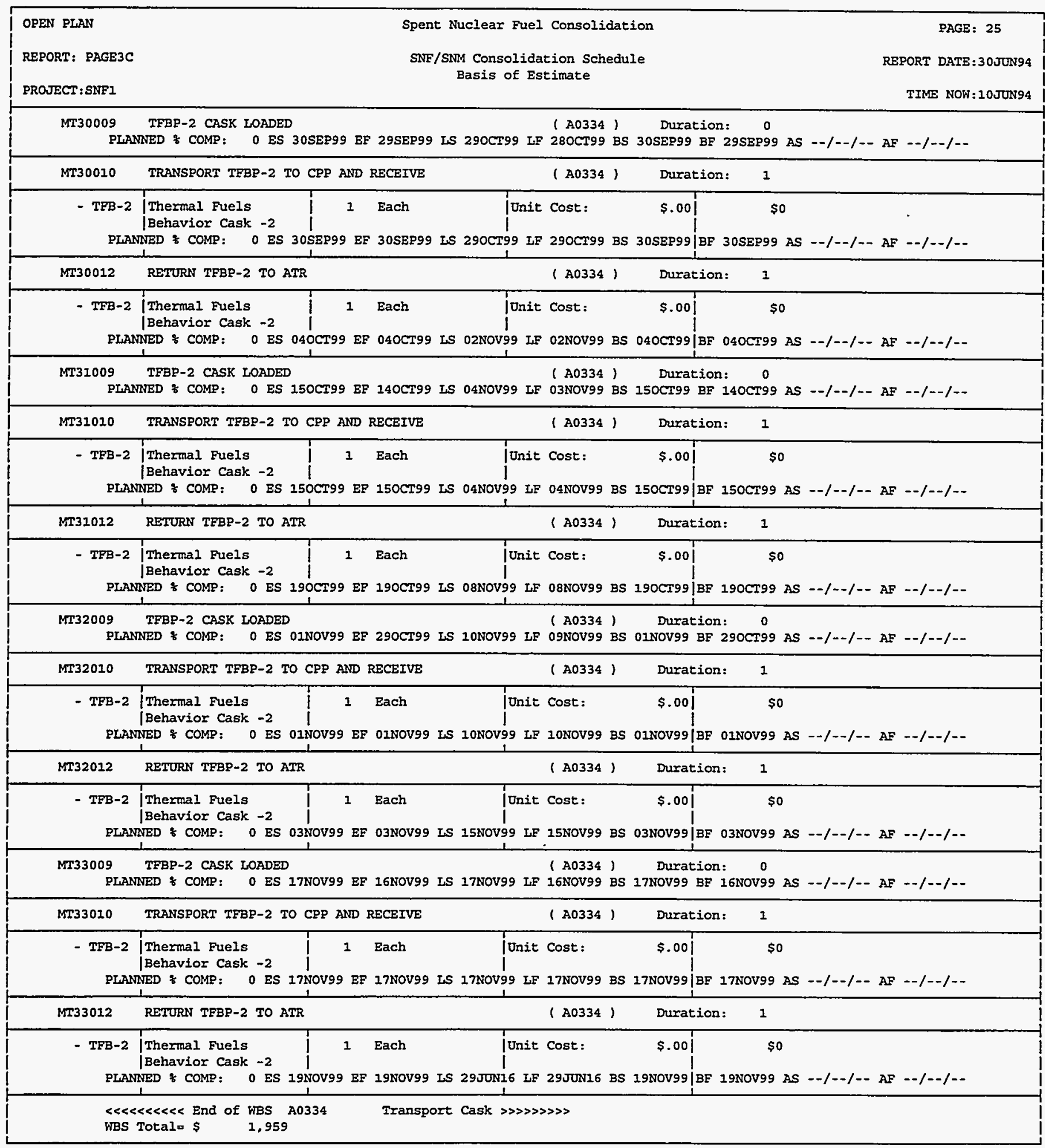




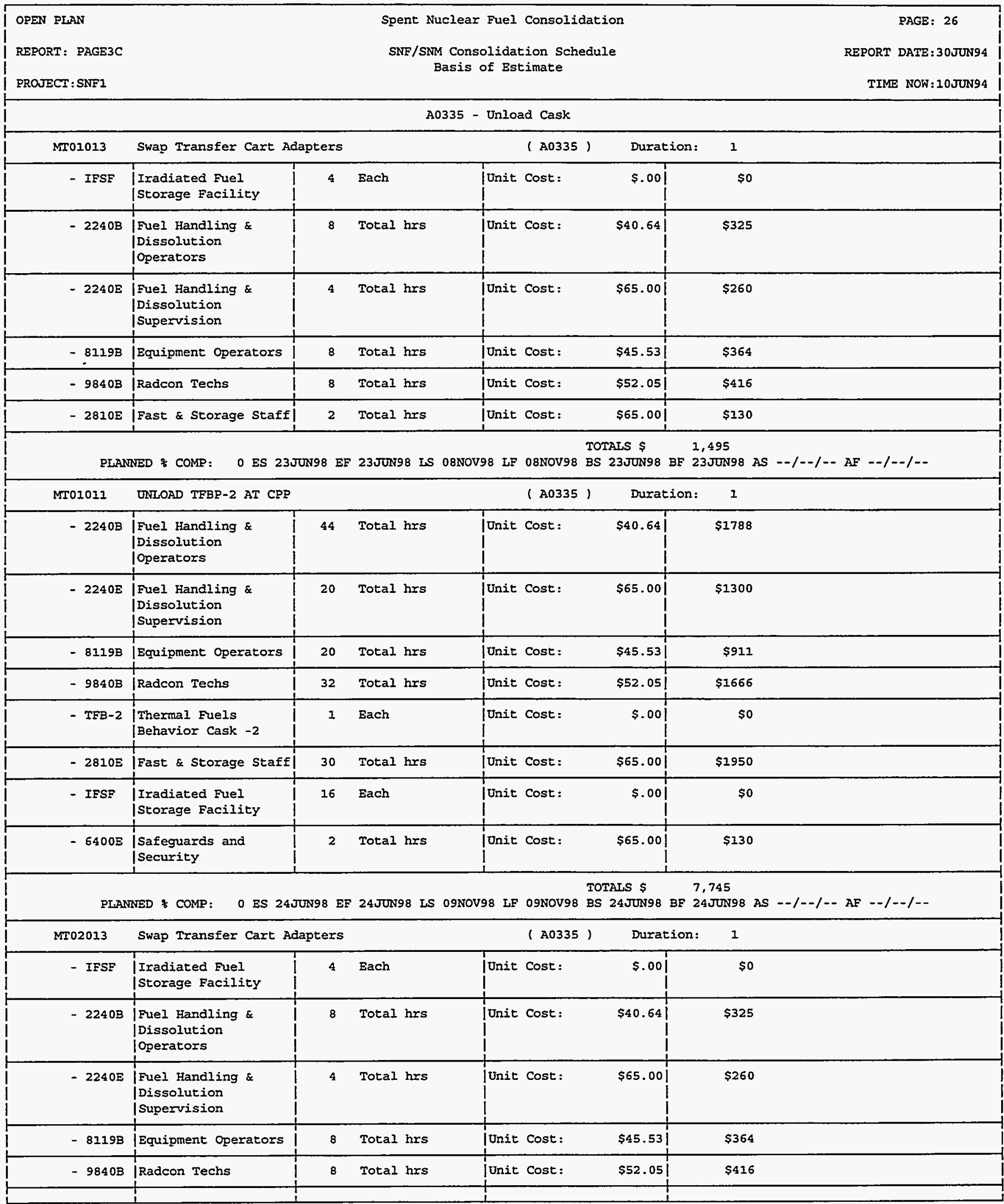




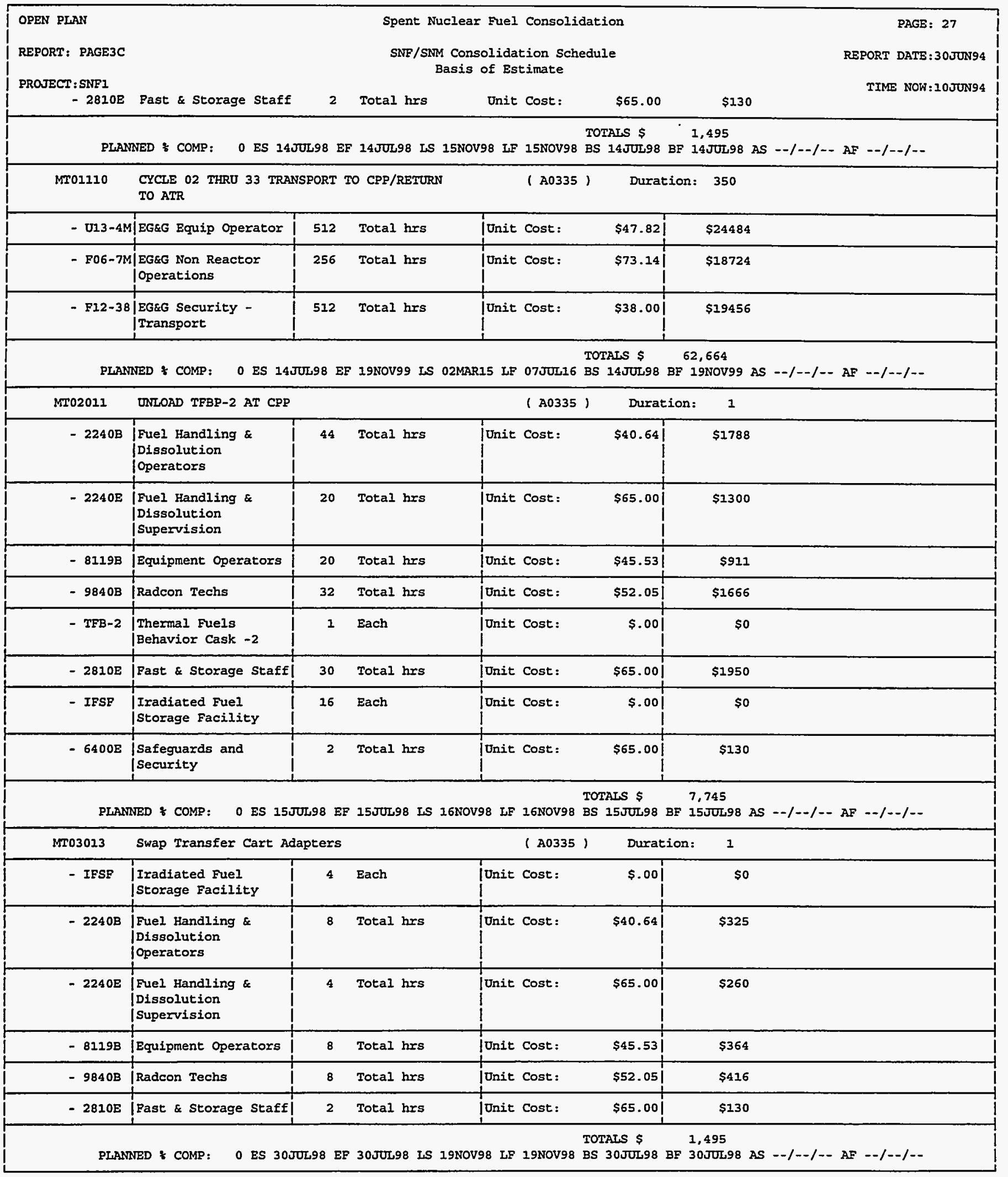

$D-91$ 


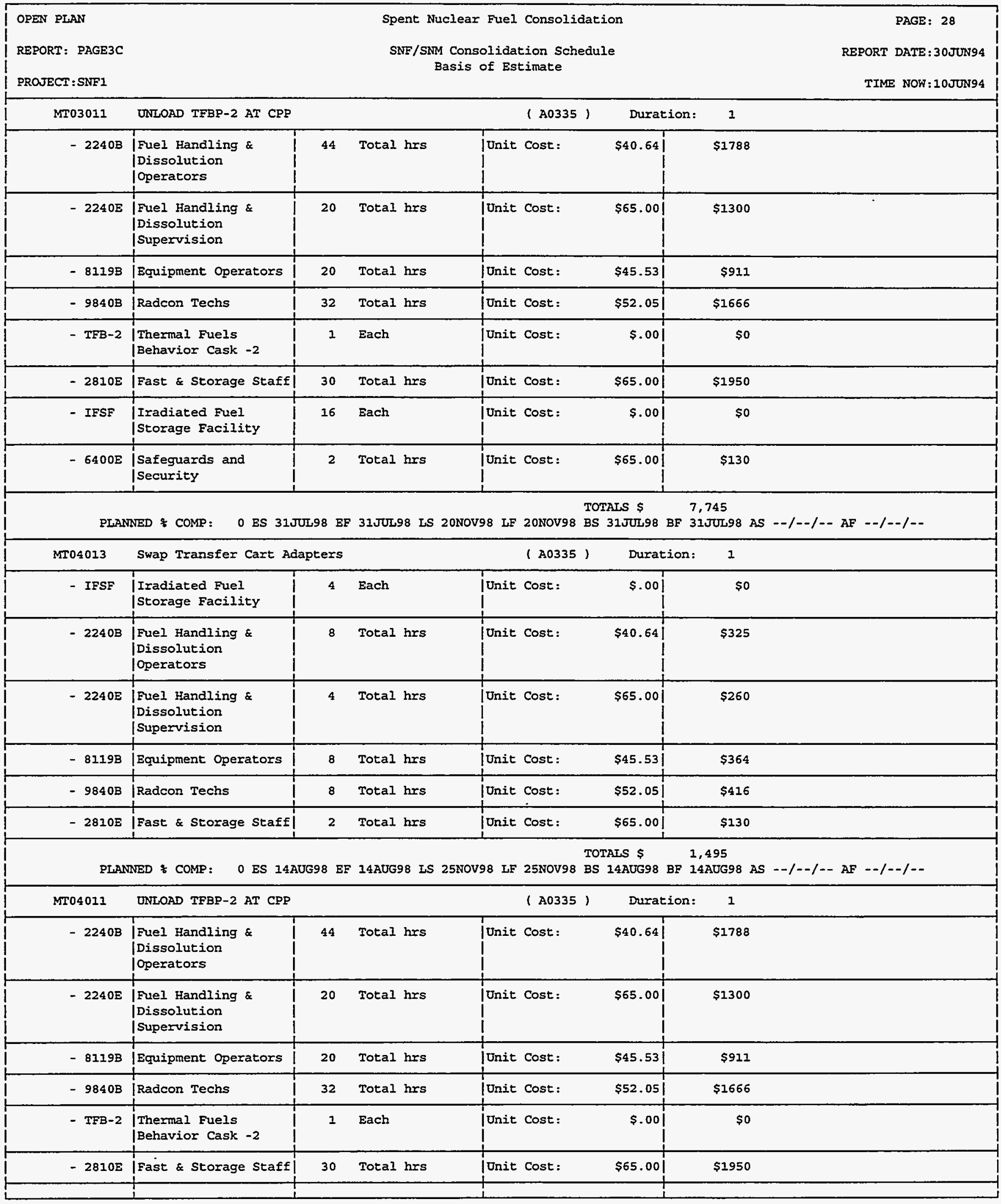




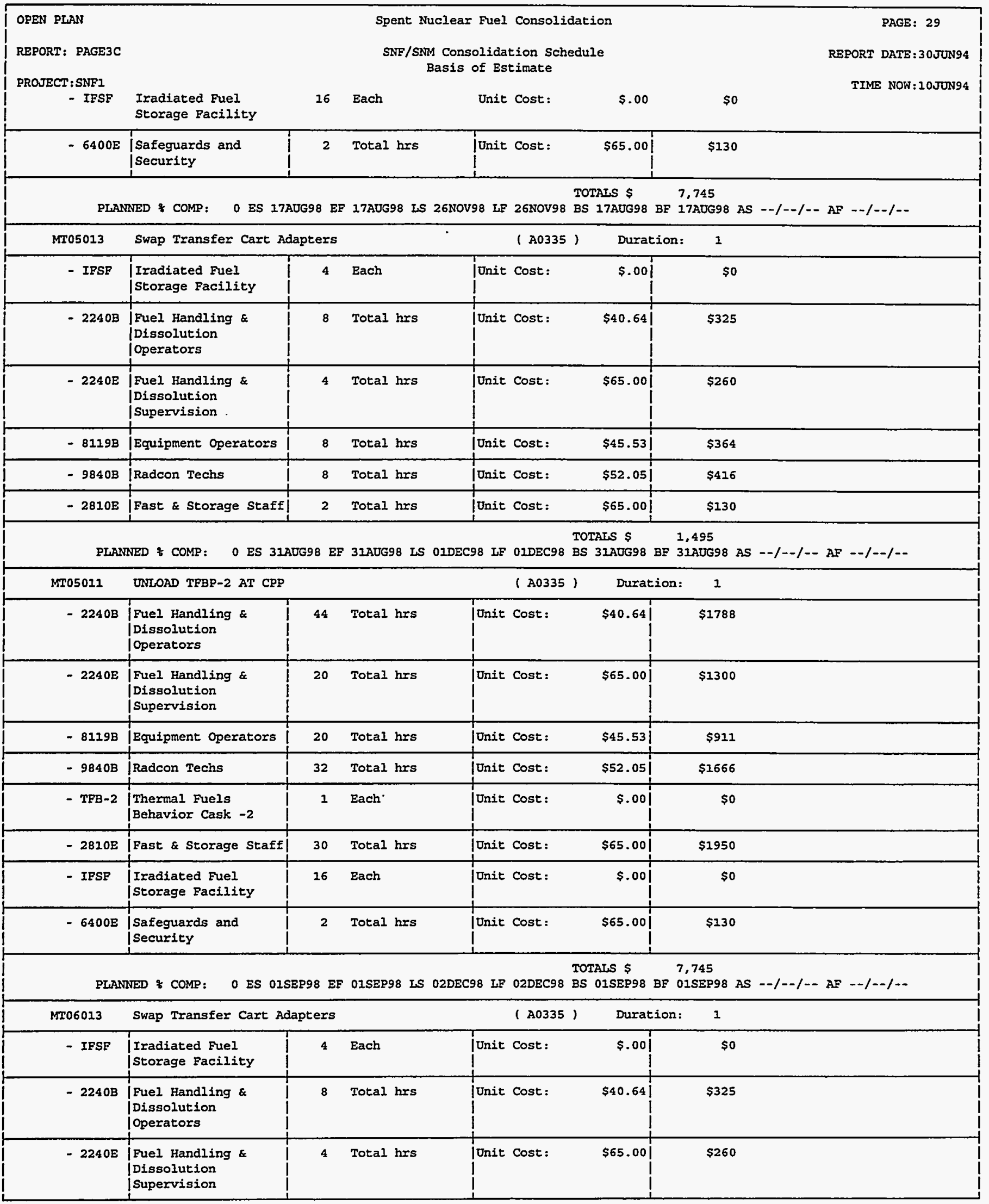

$D-93$ 


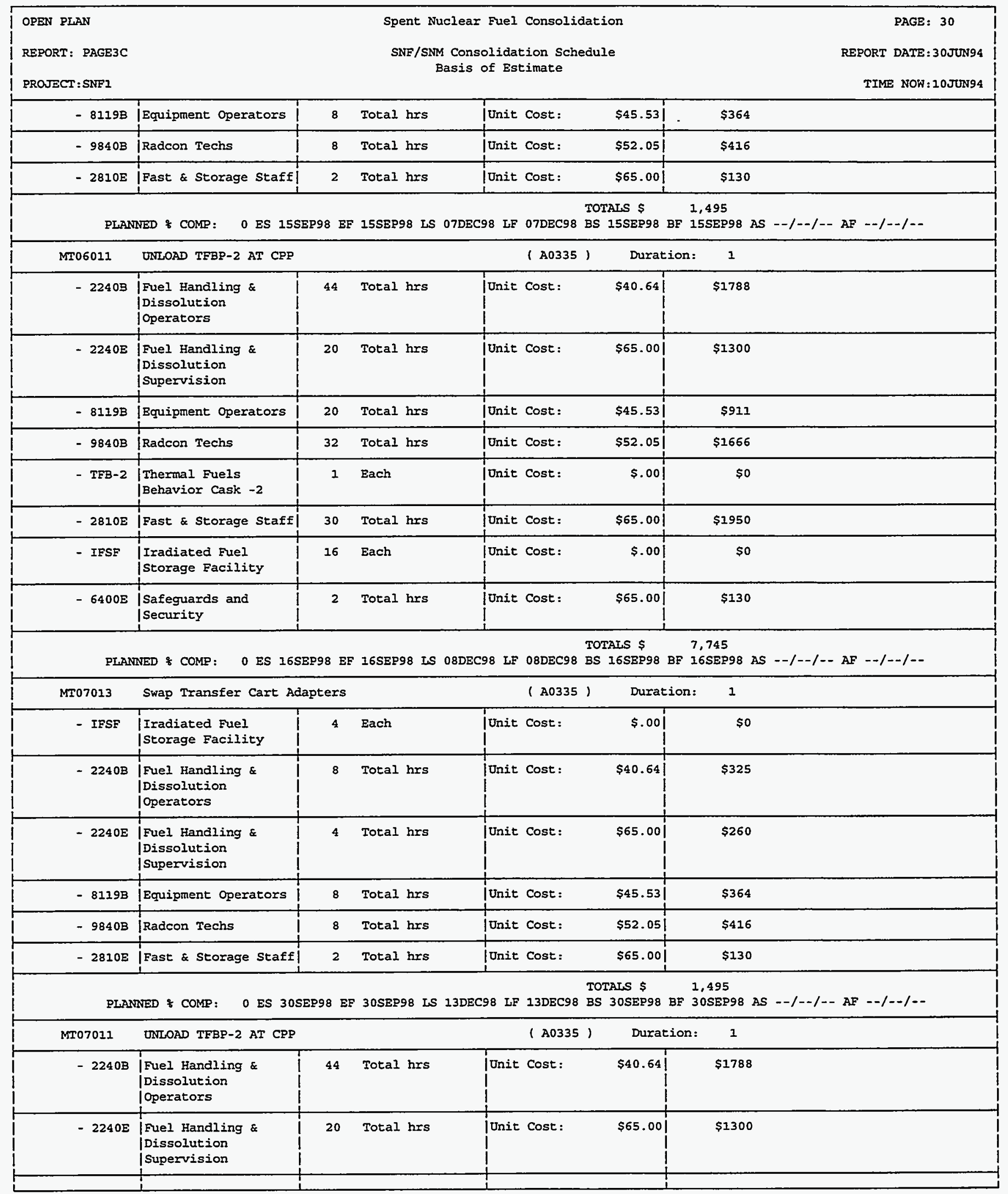




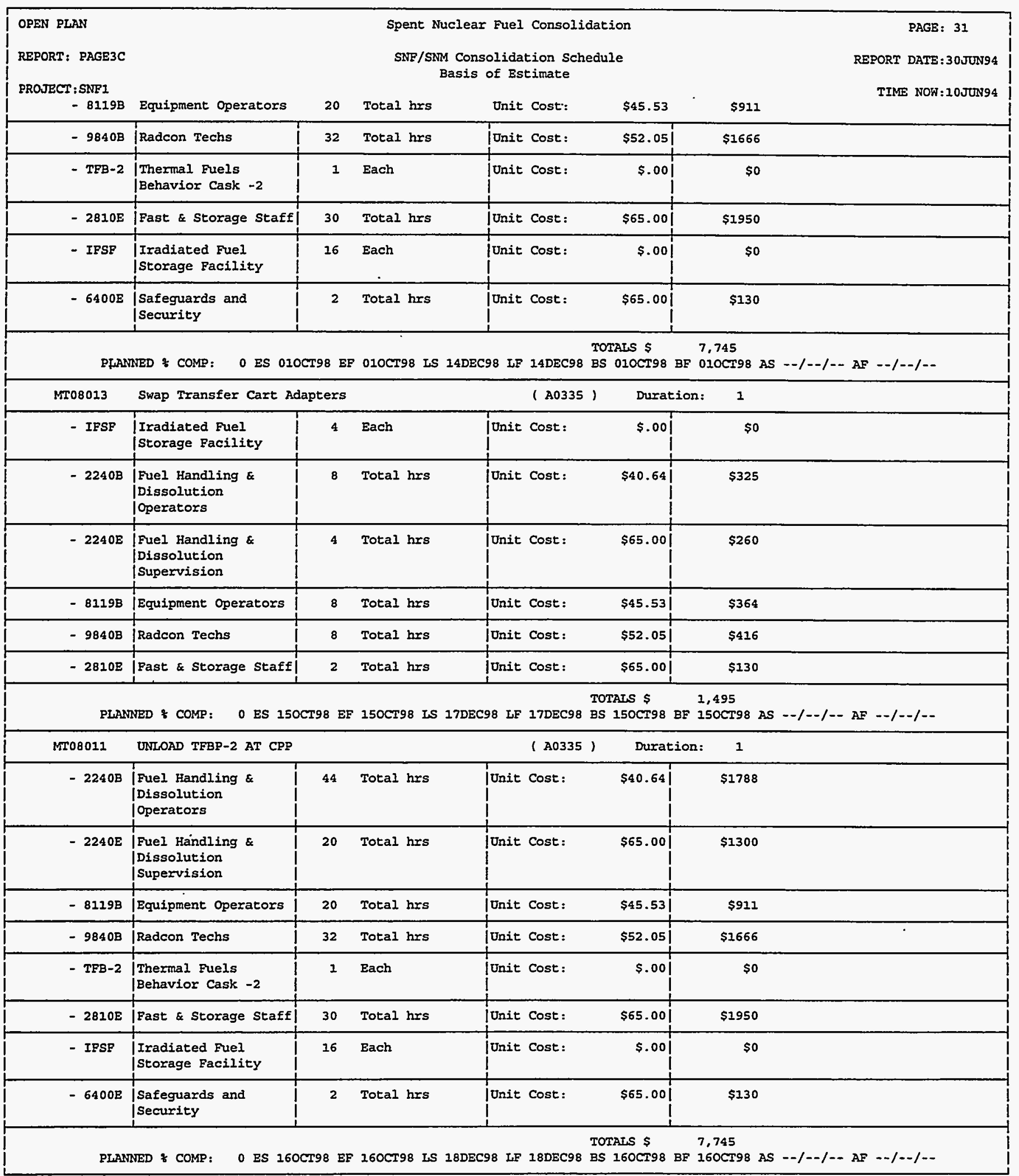




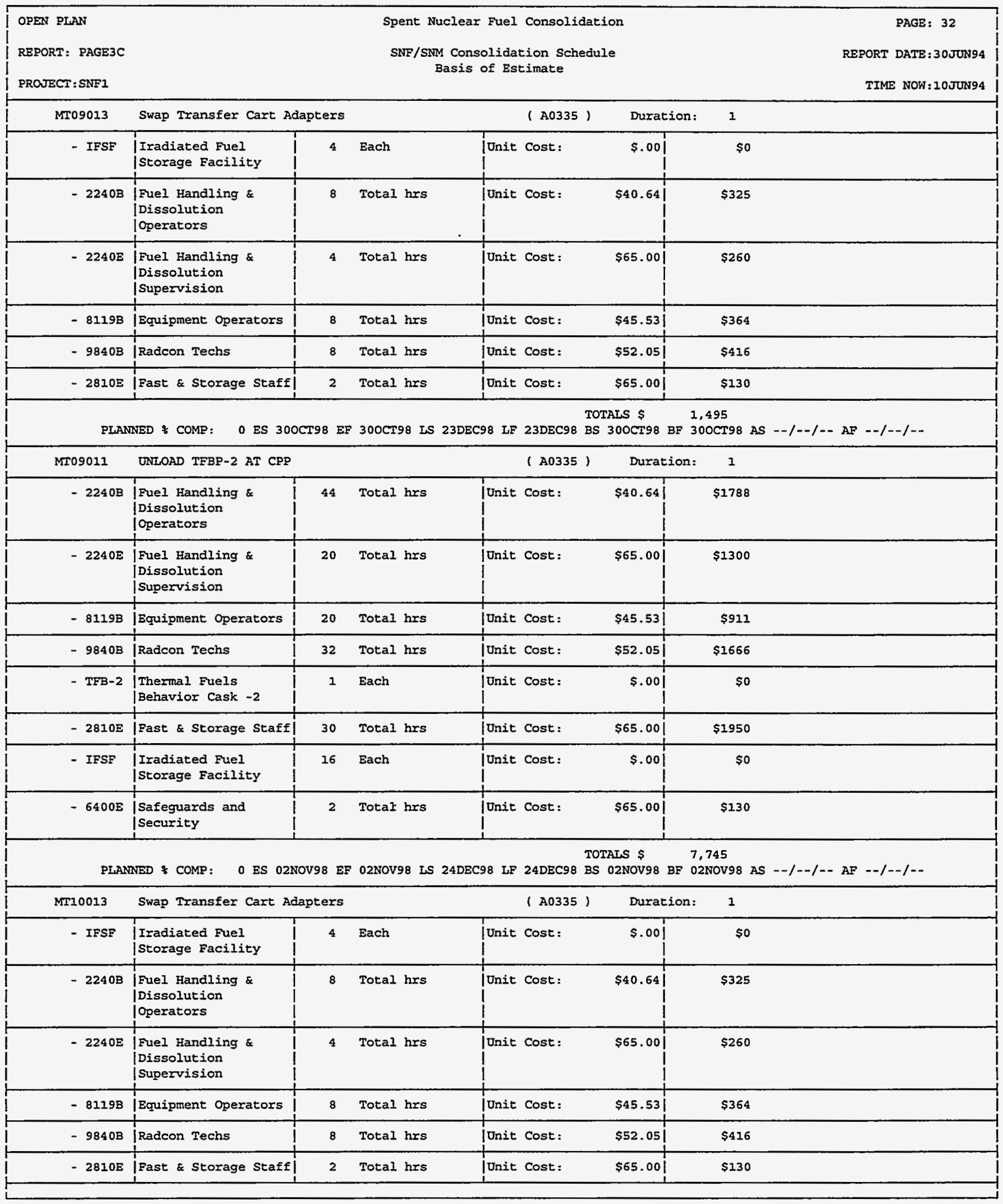




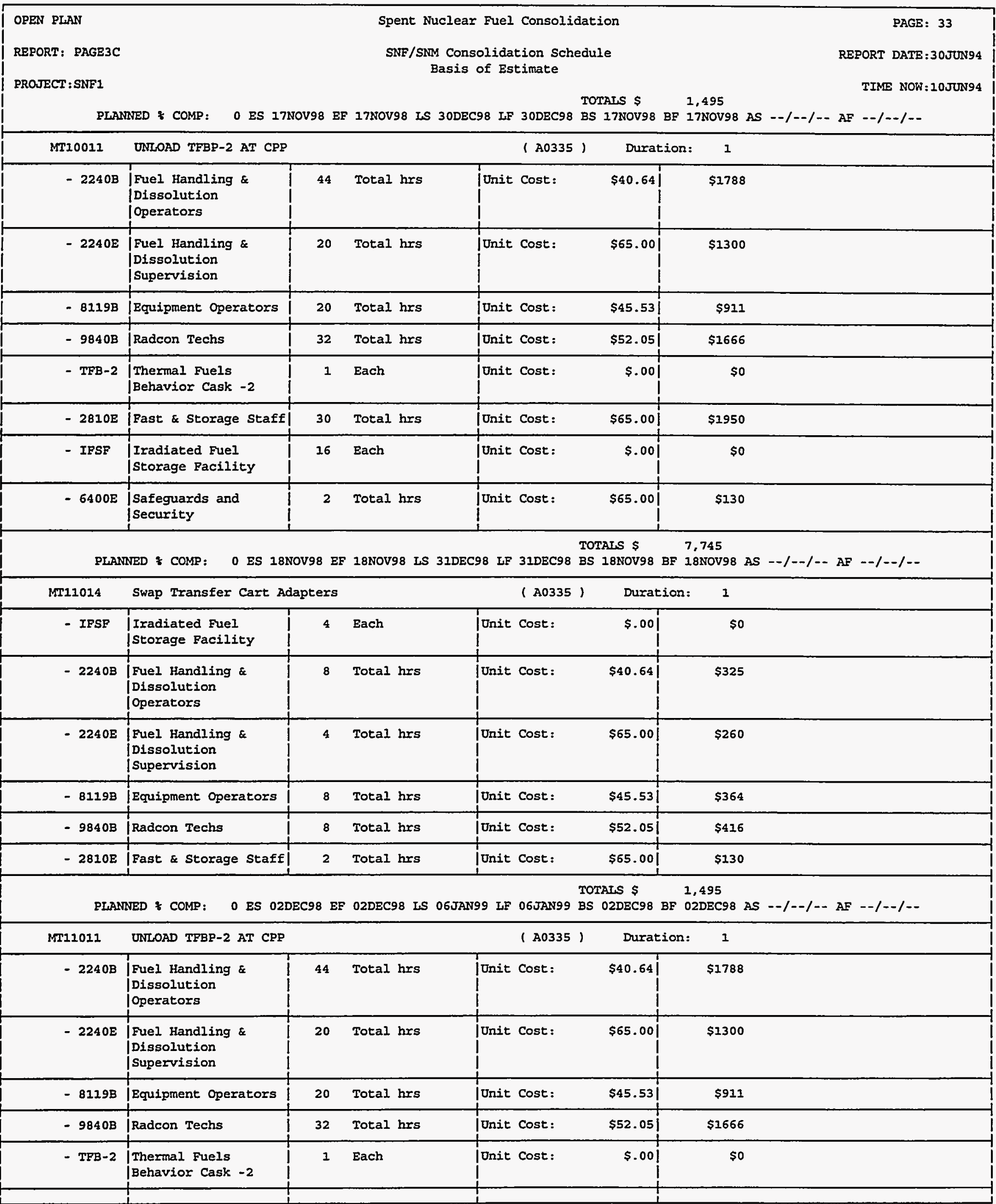




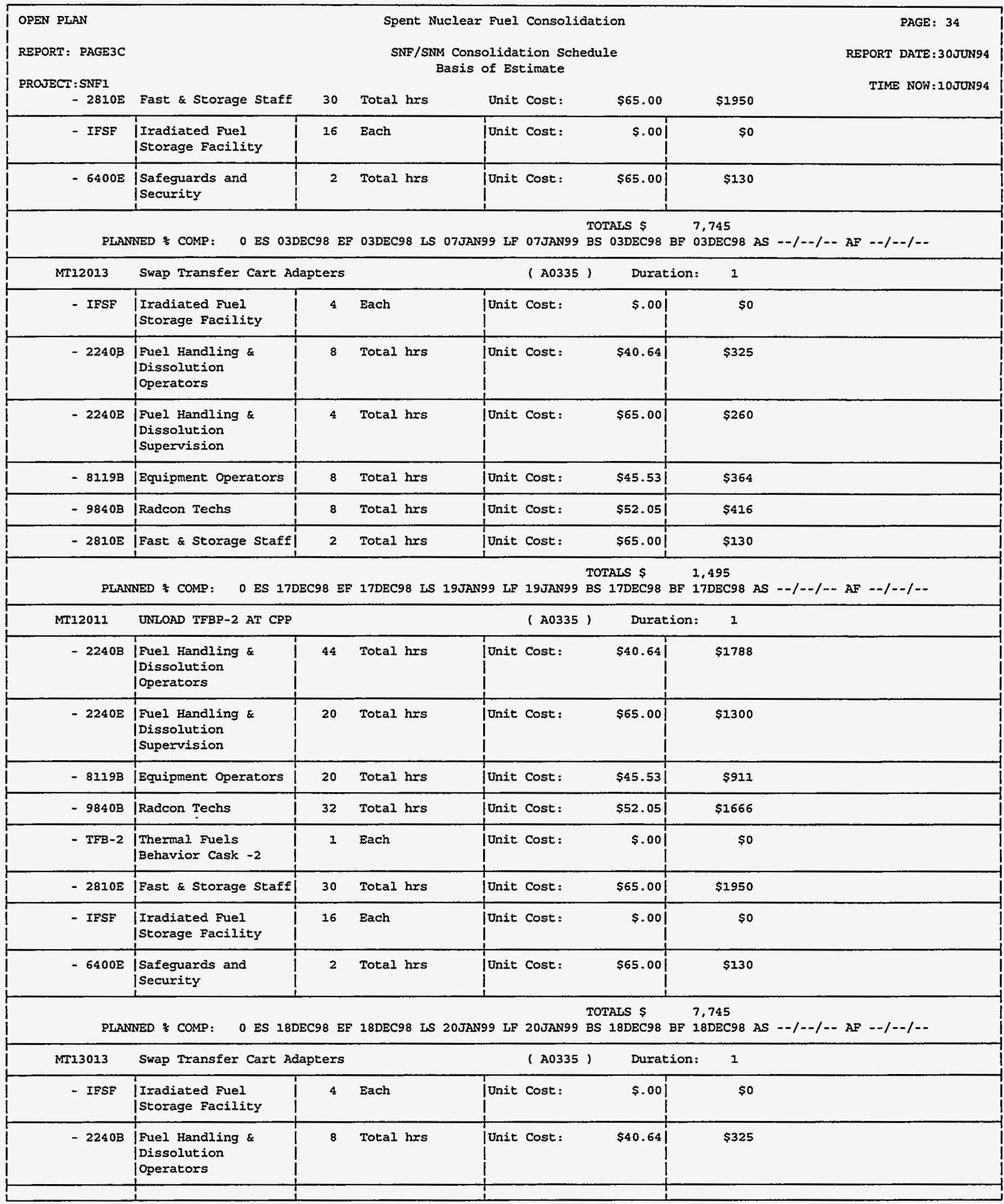




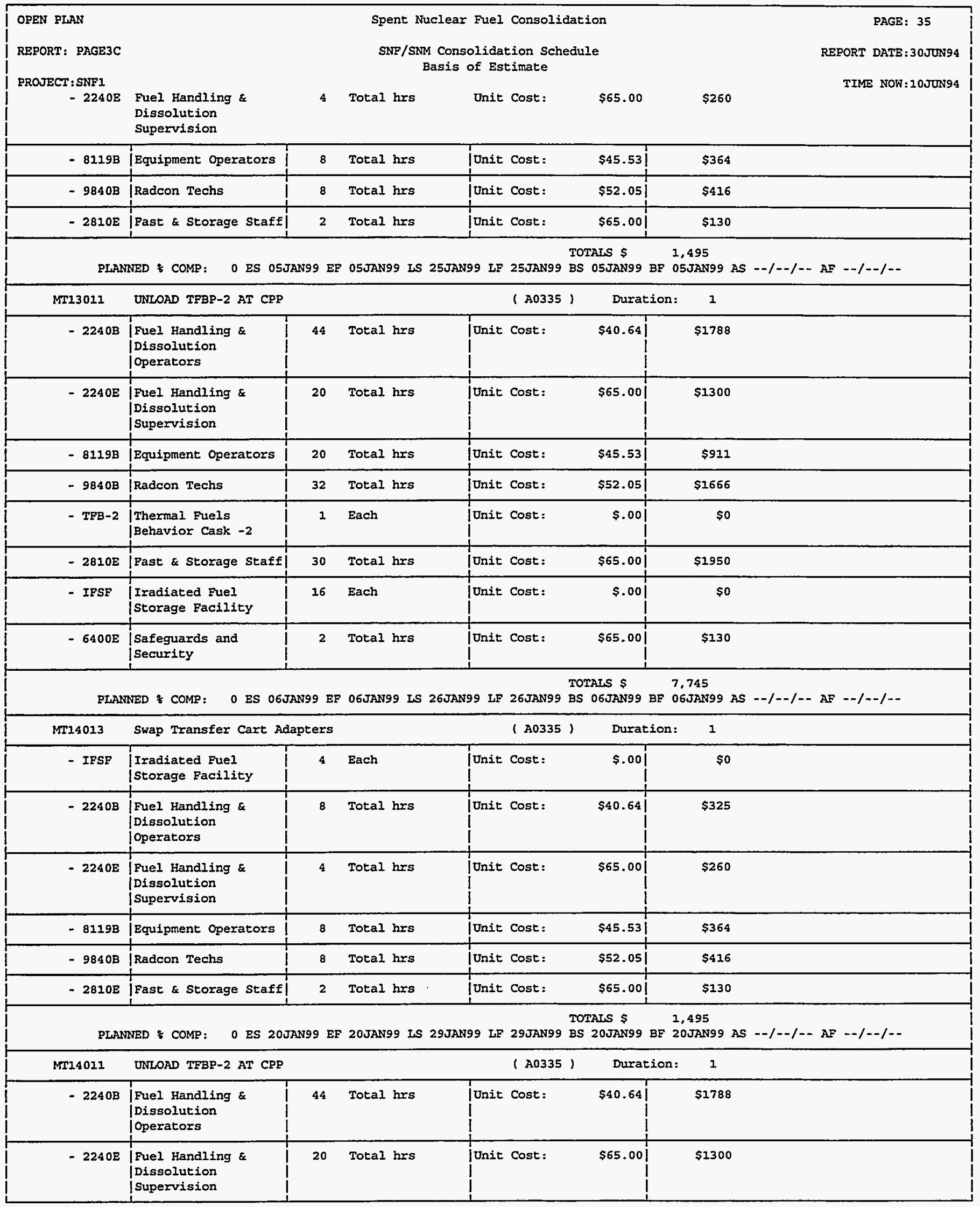




$$
D-100
$$




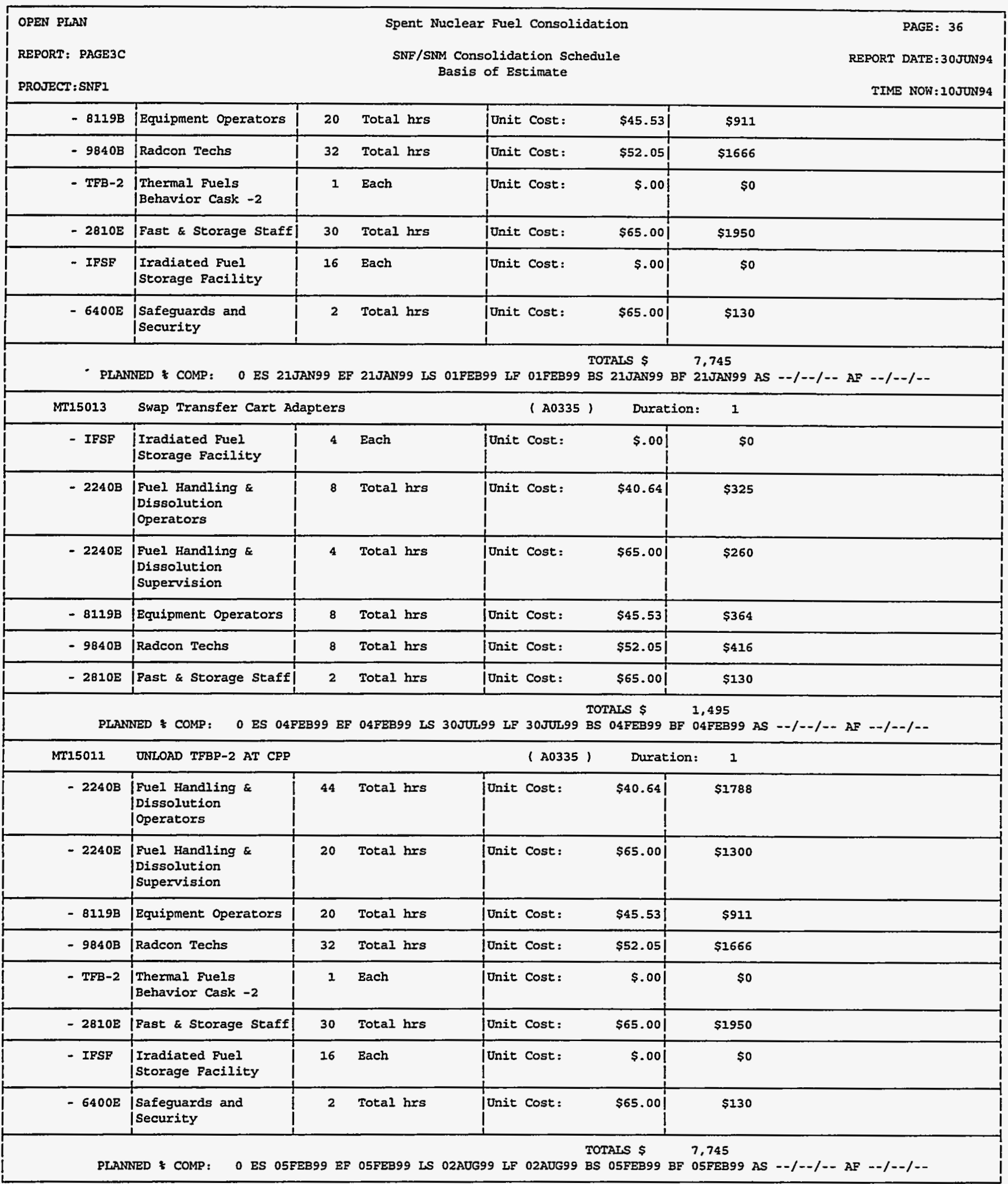




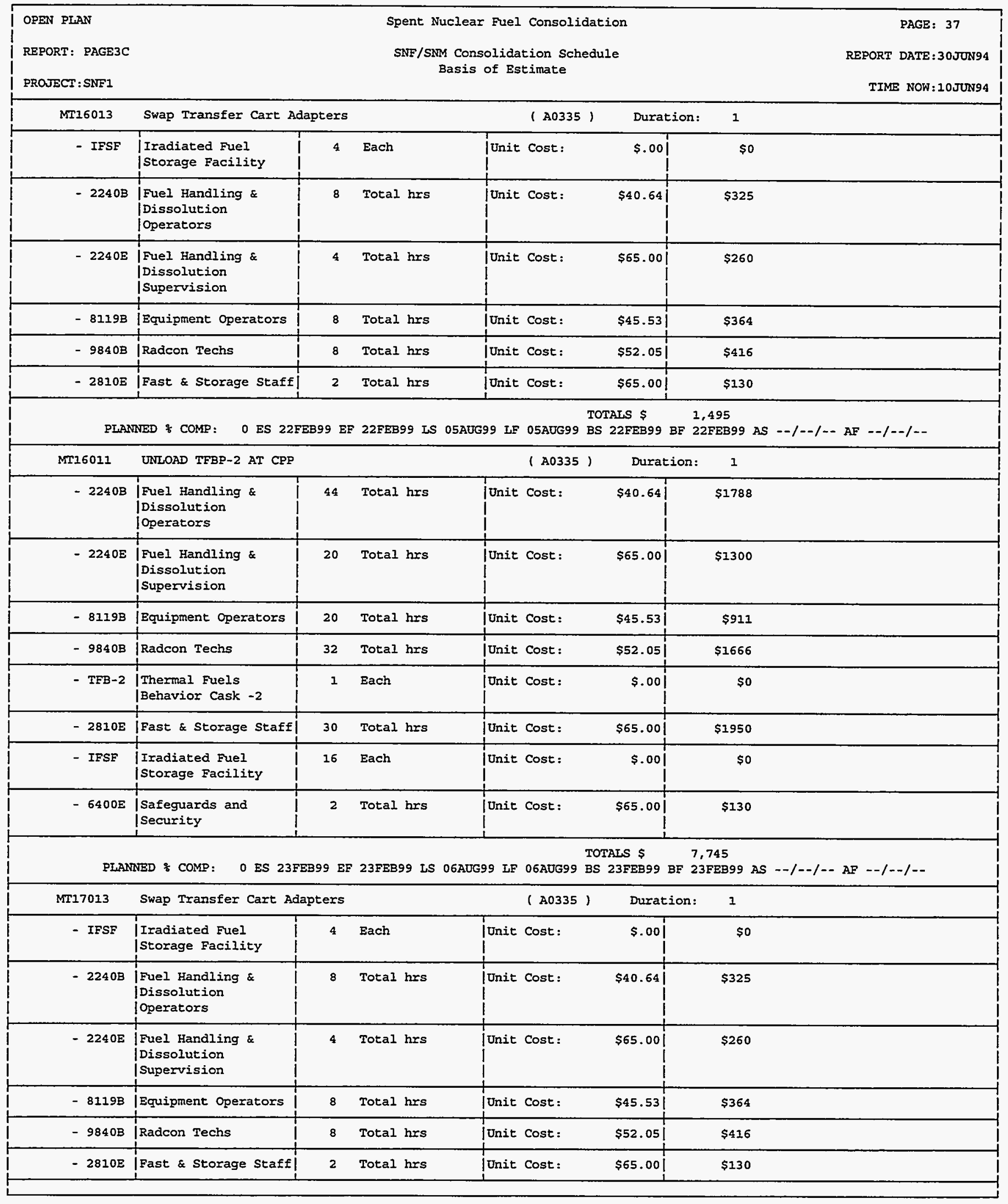




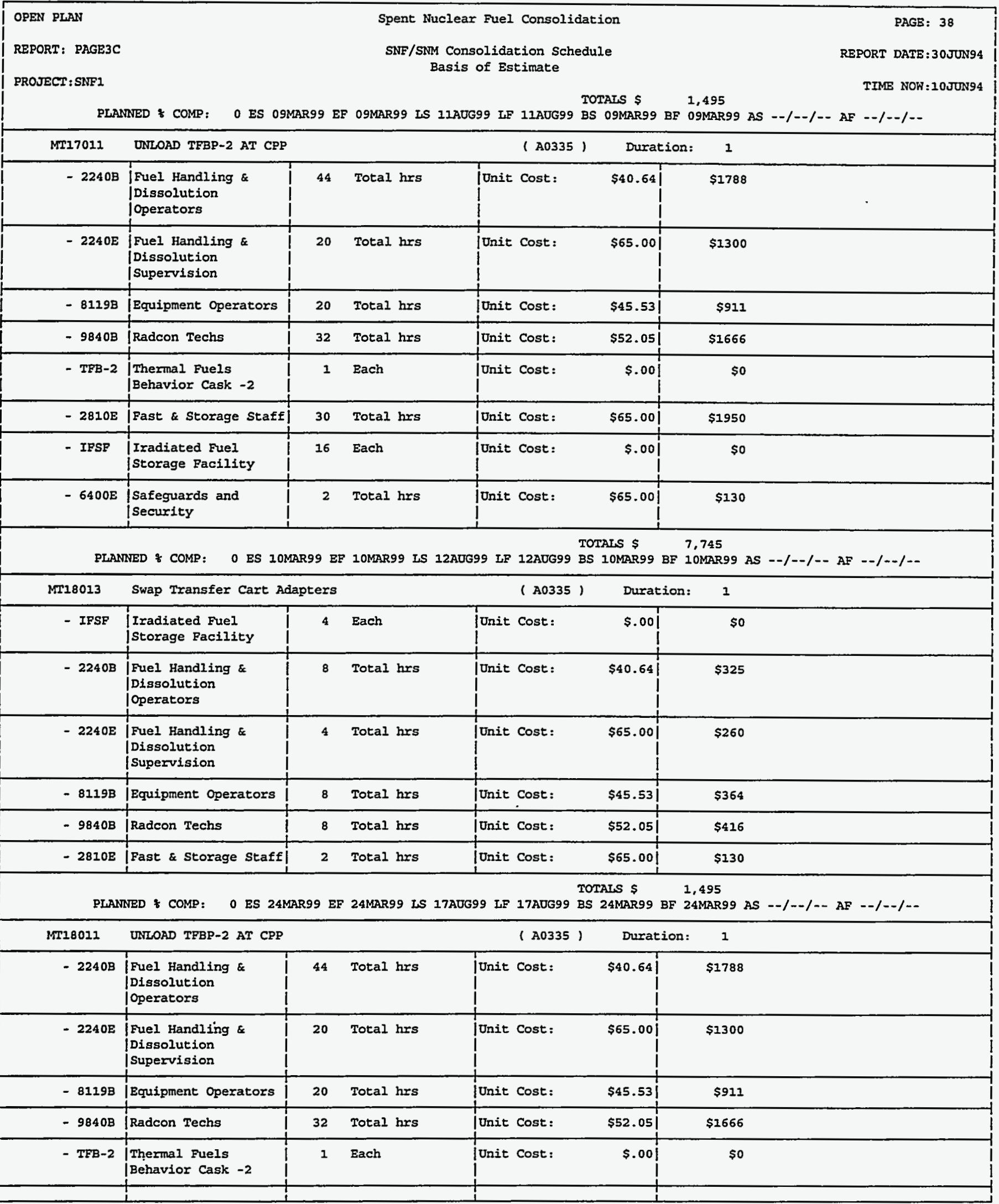




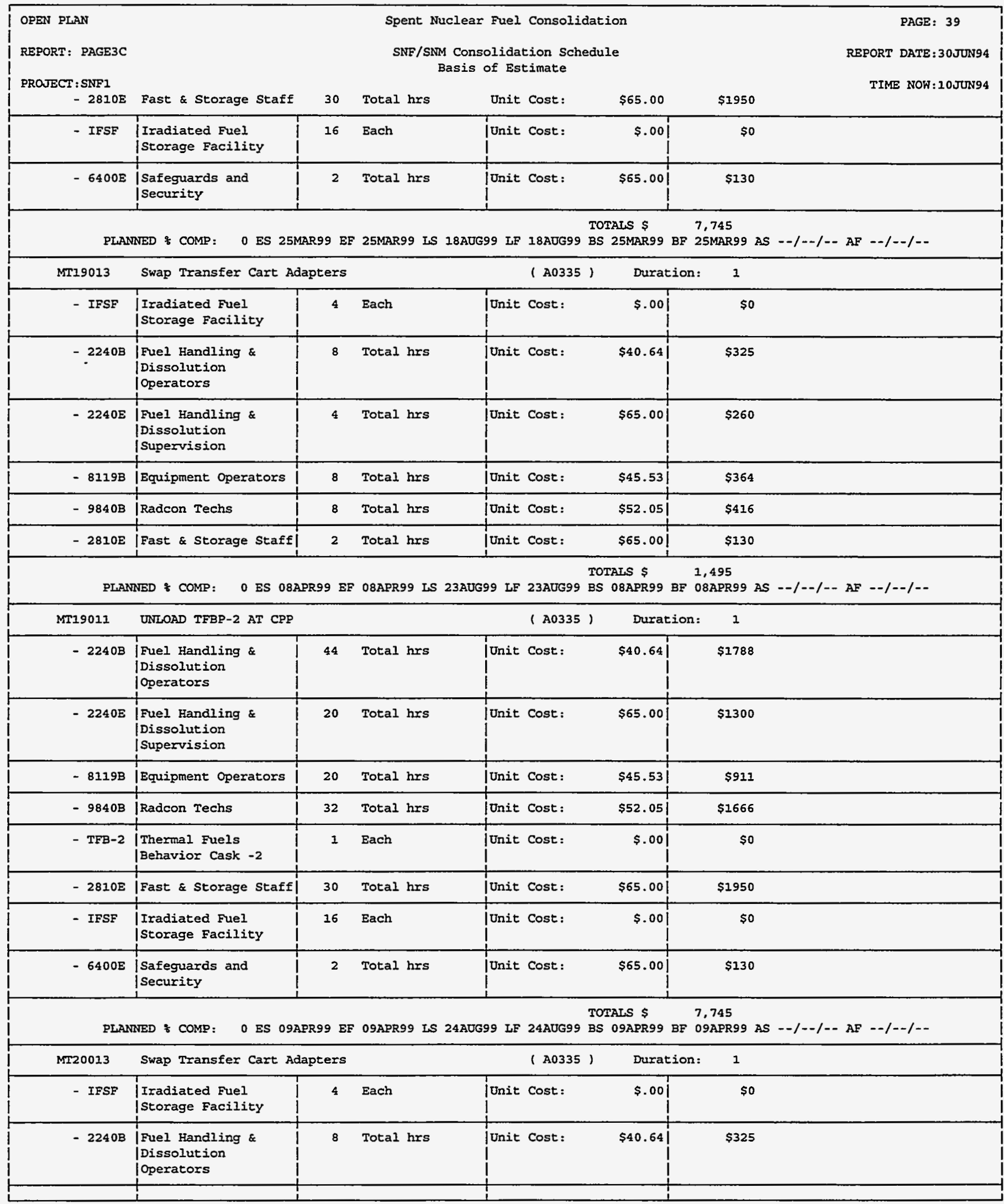




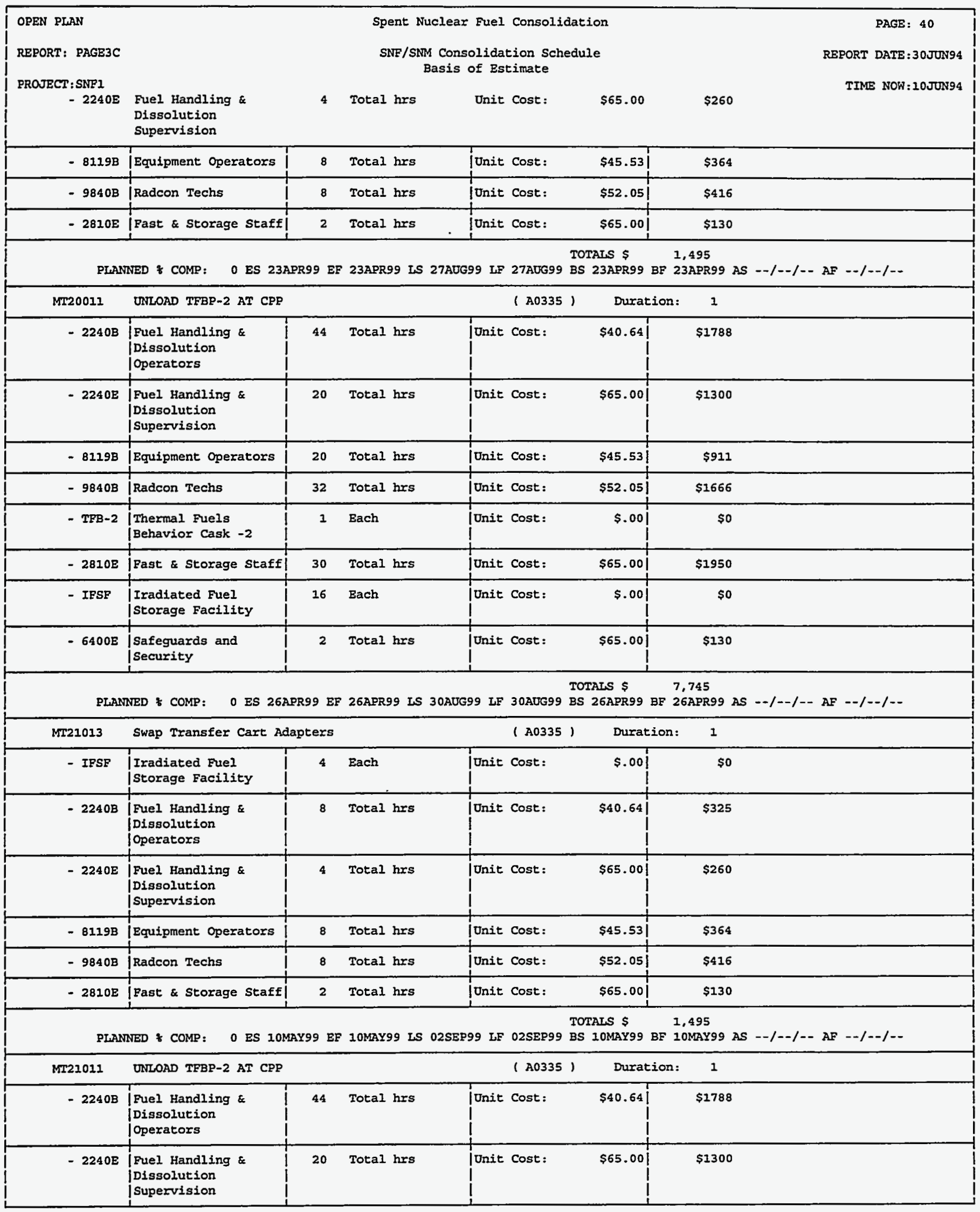

\section{D-105}


D-106 


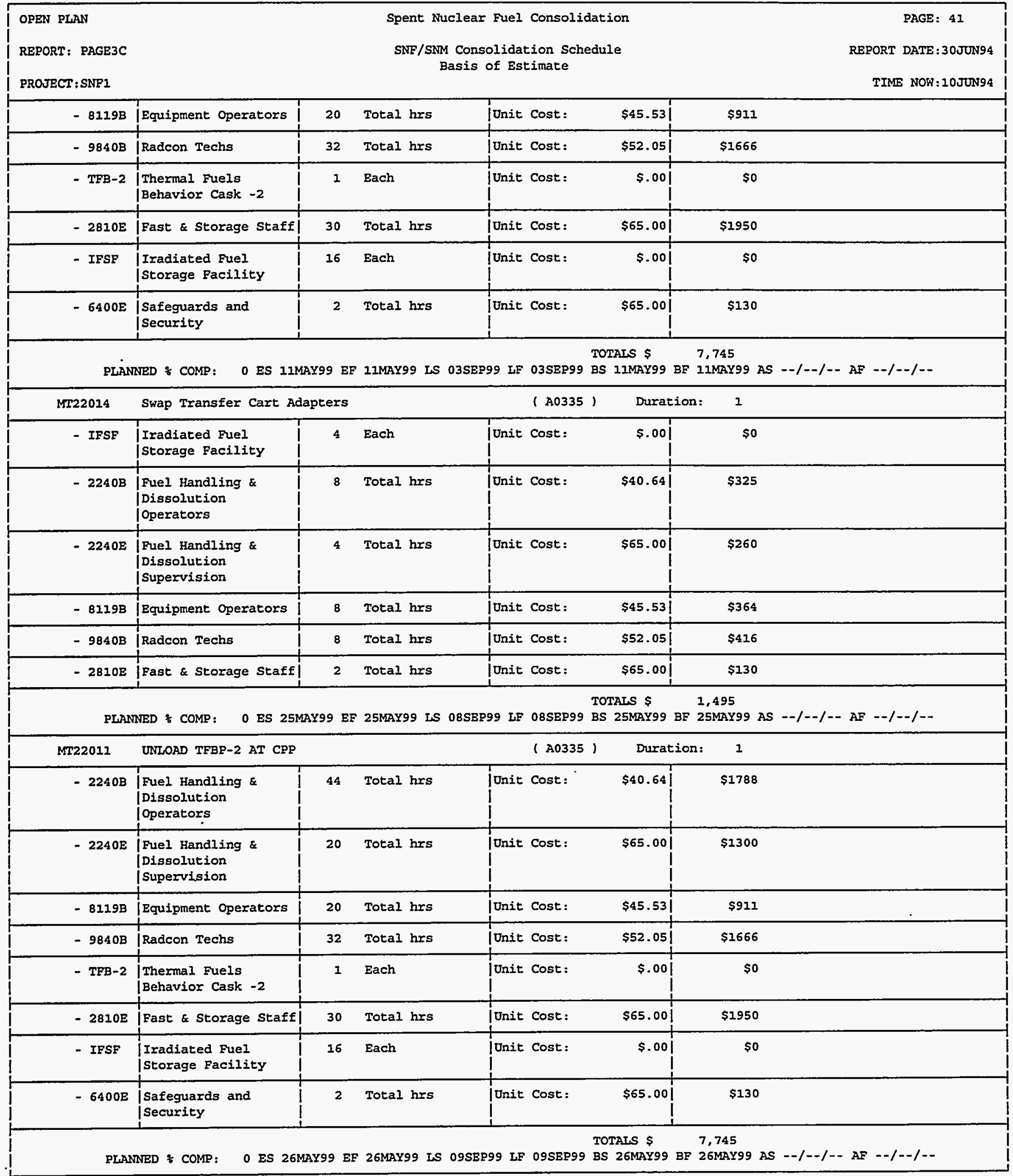

\section{D-107}




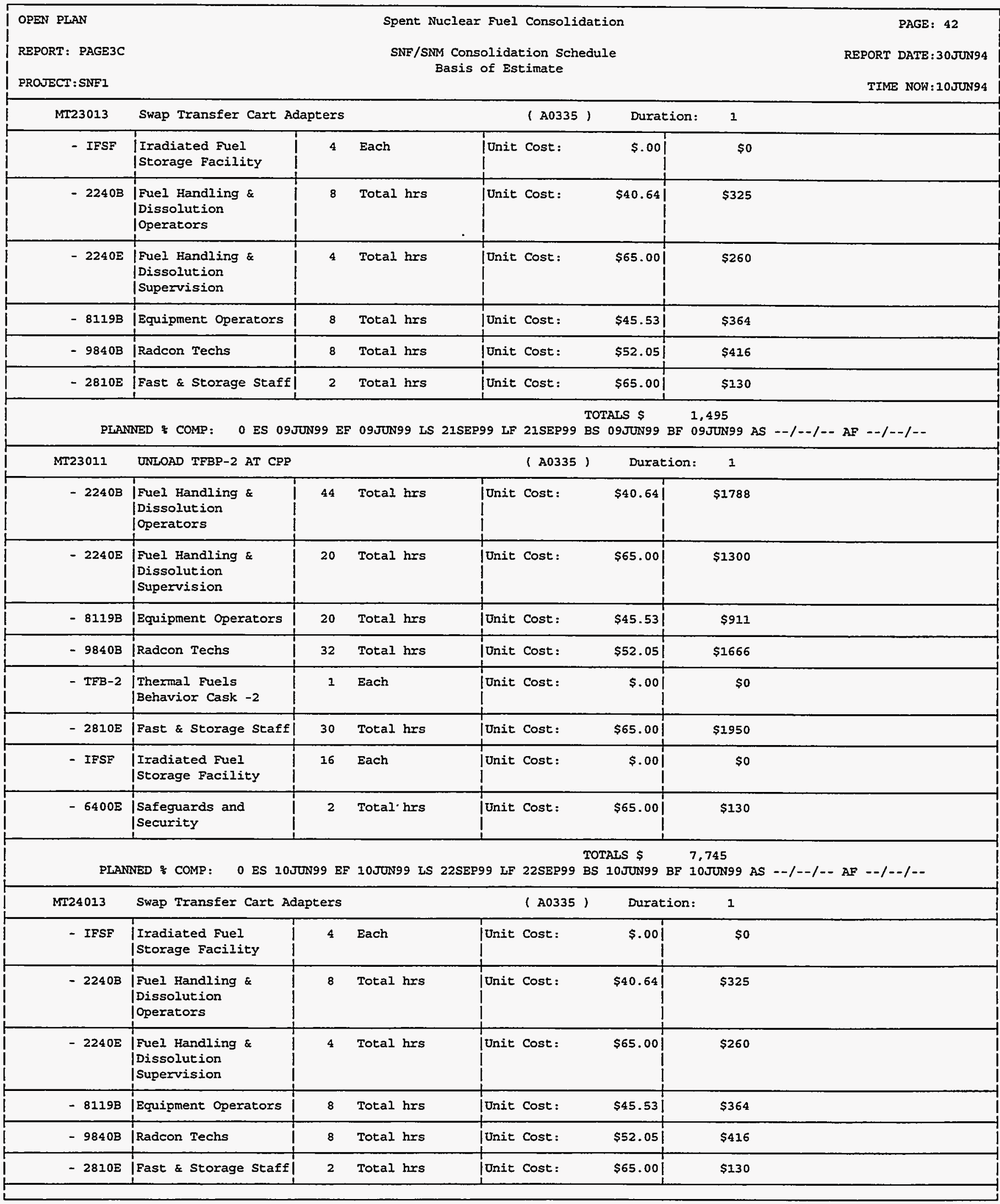




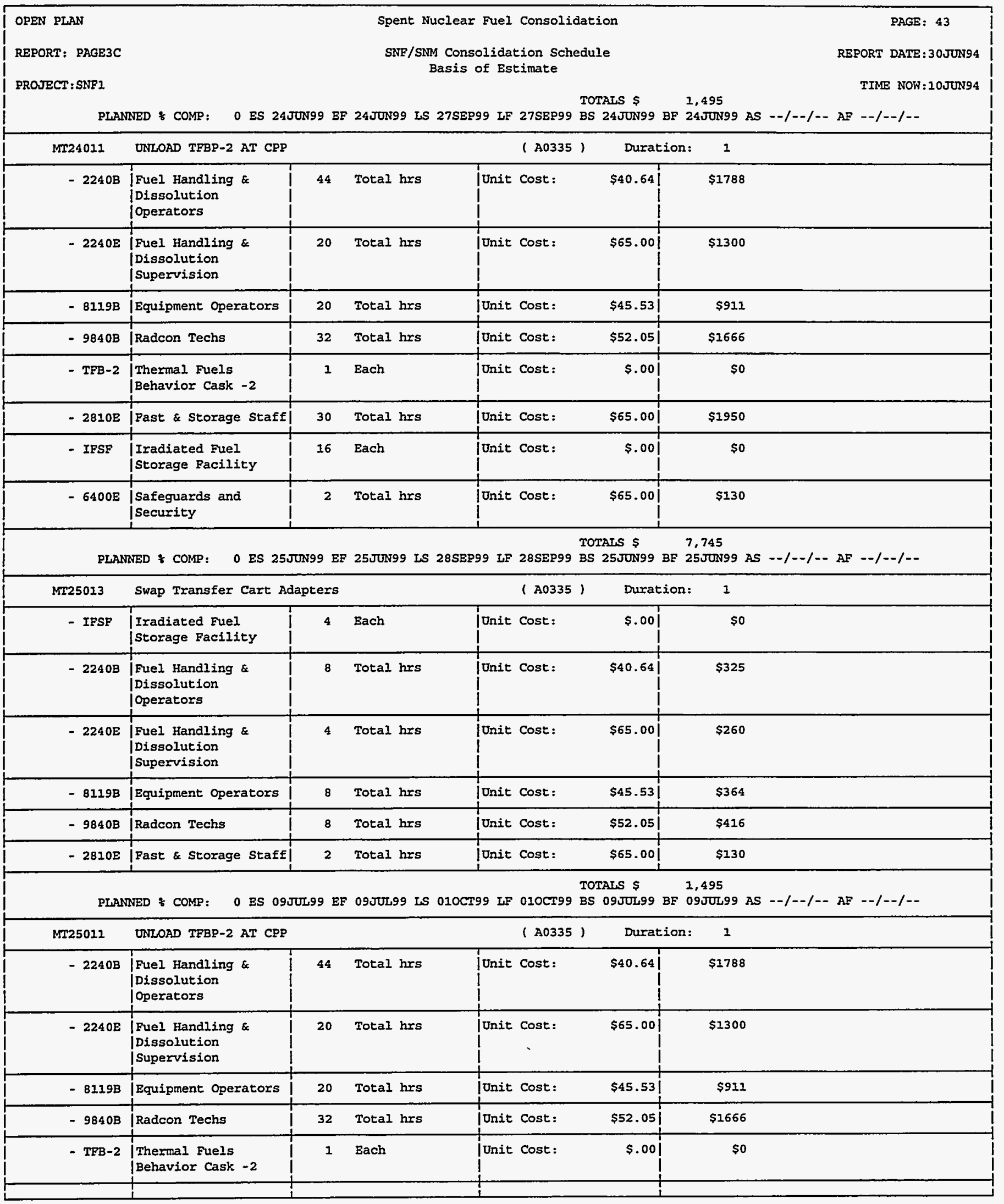




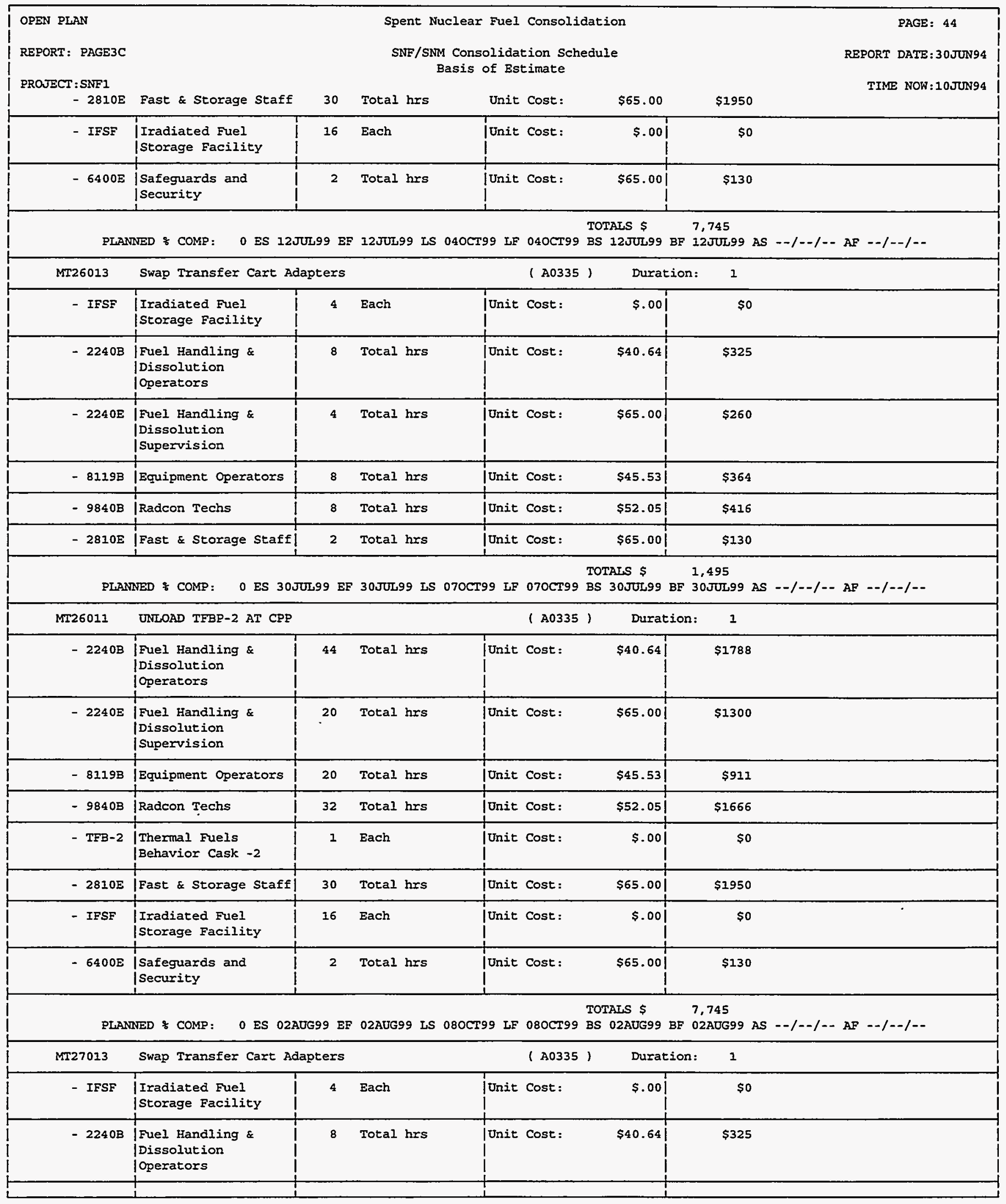




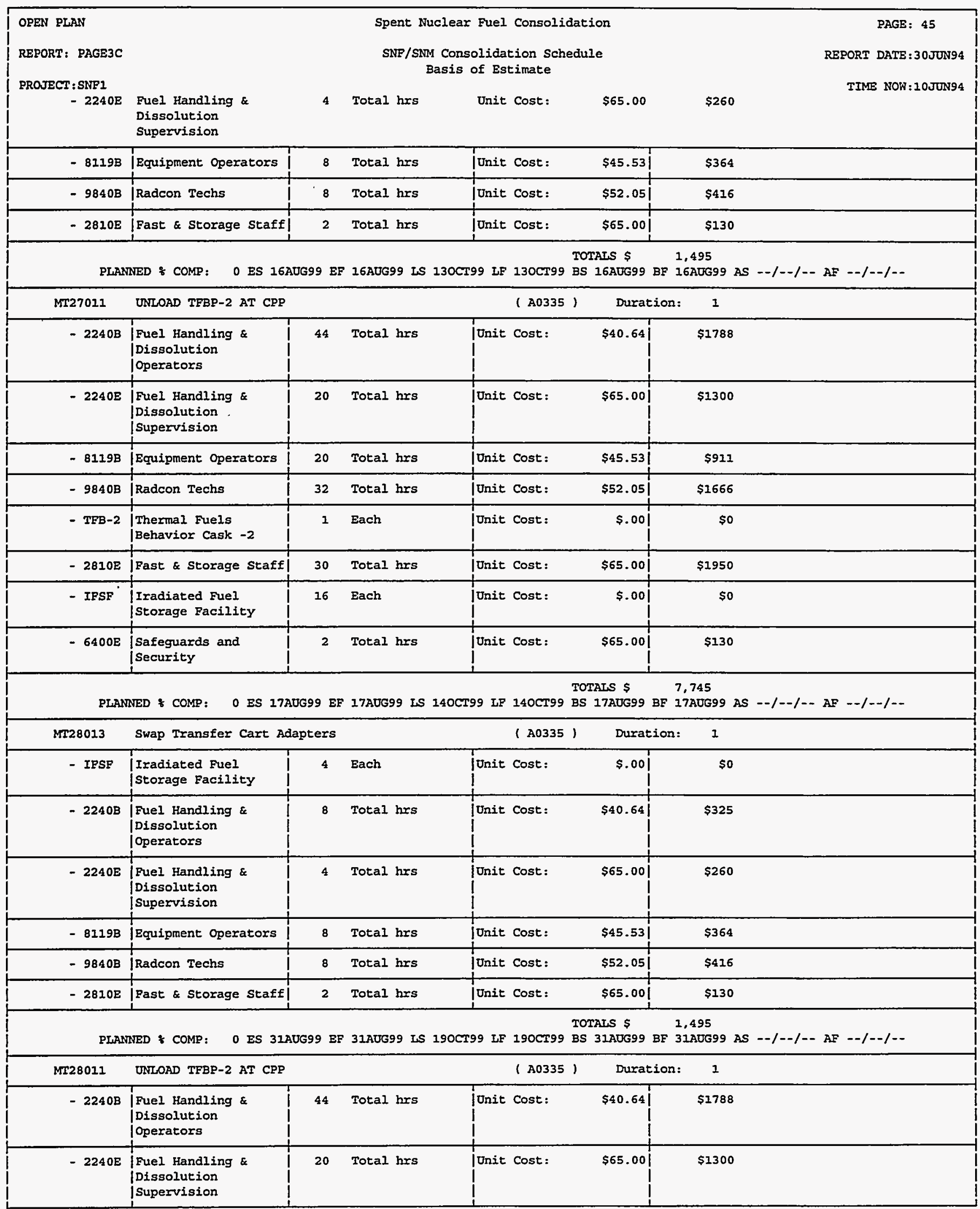




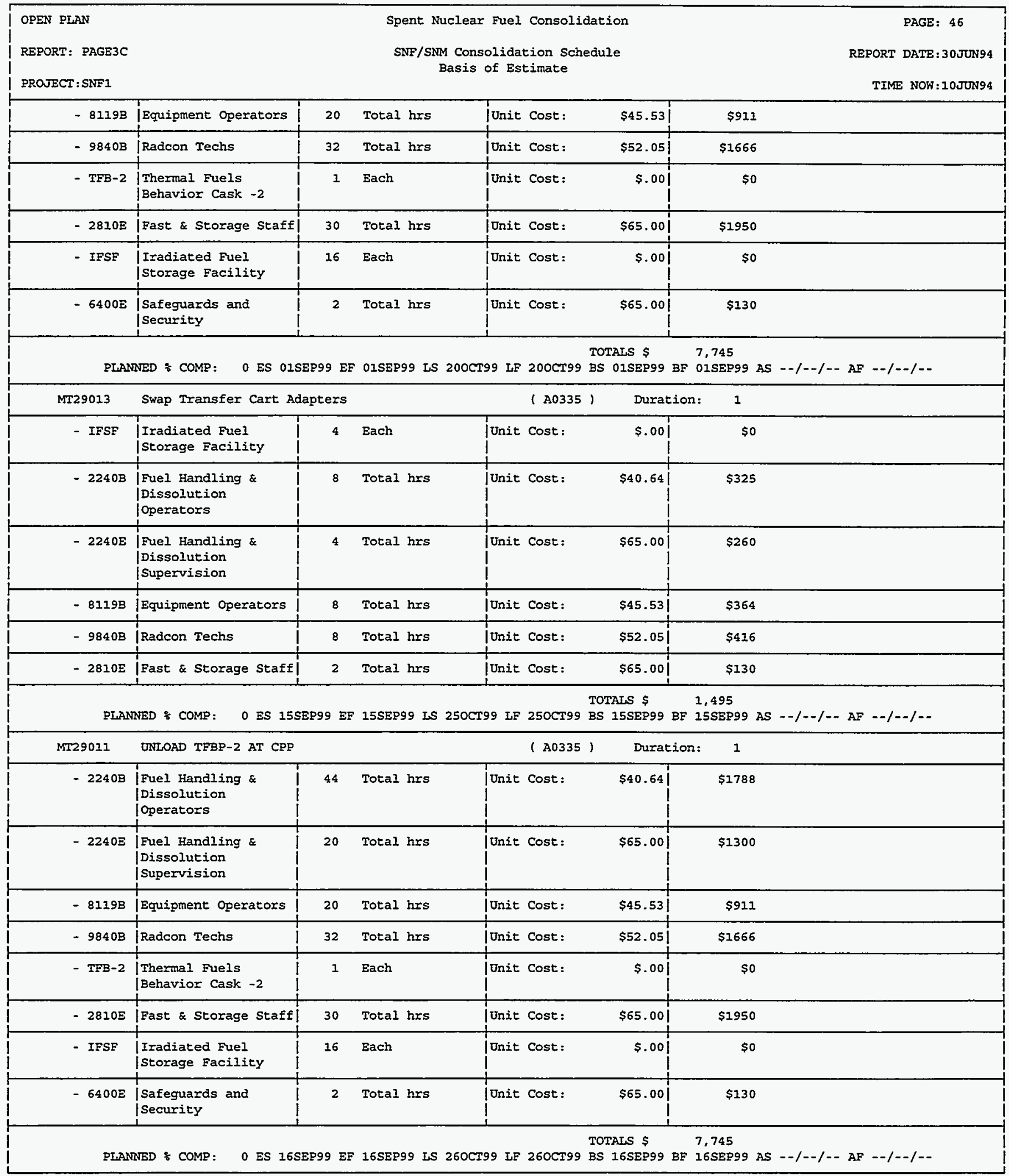




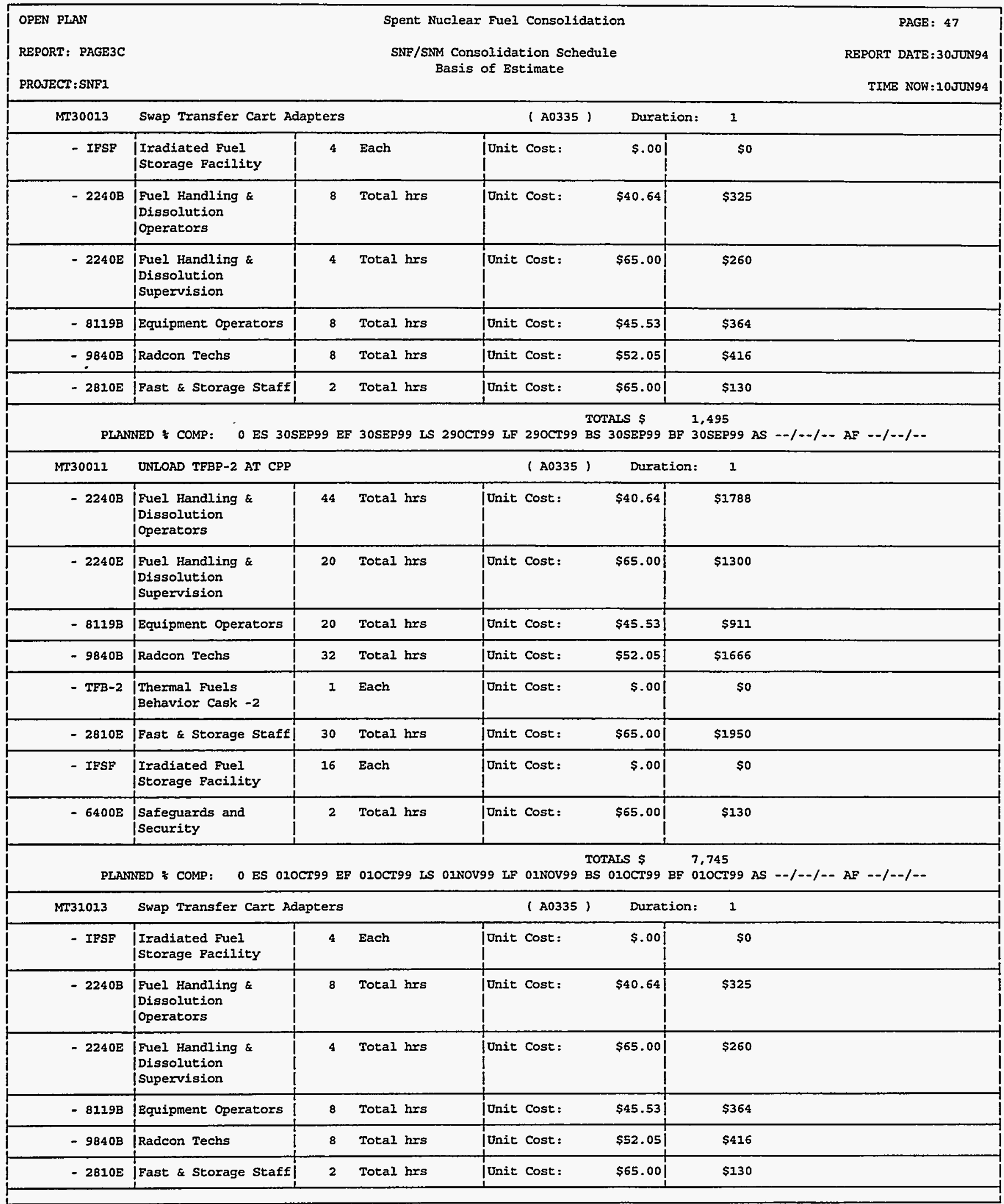

\section{$D-113$}




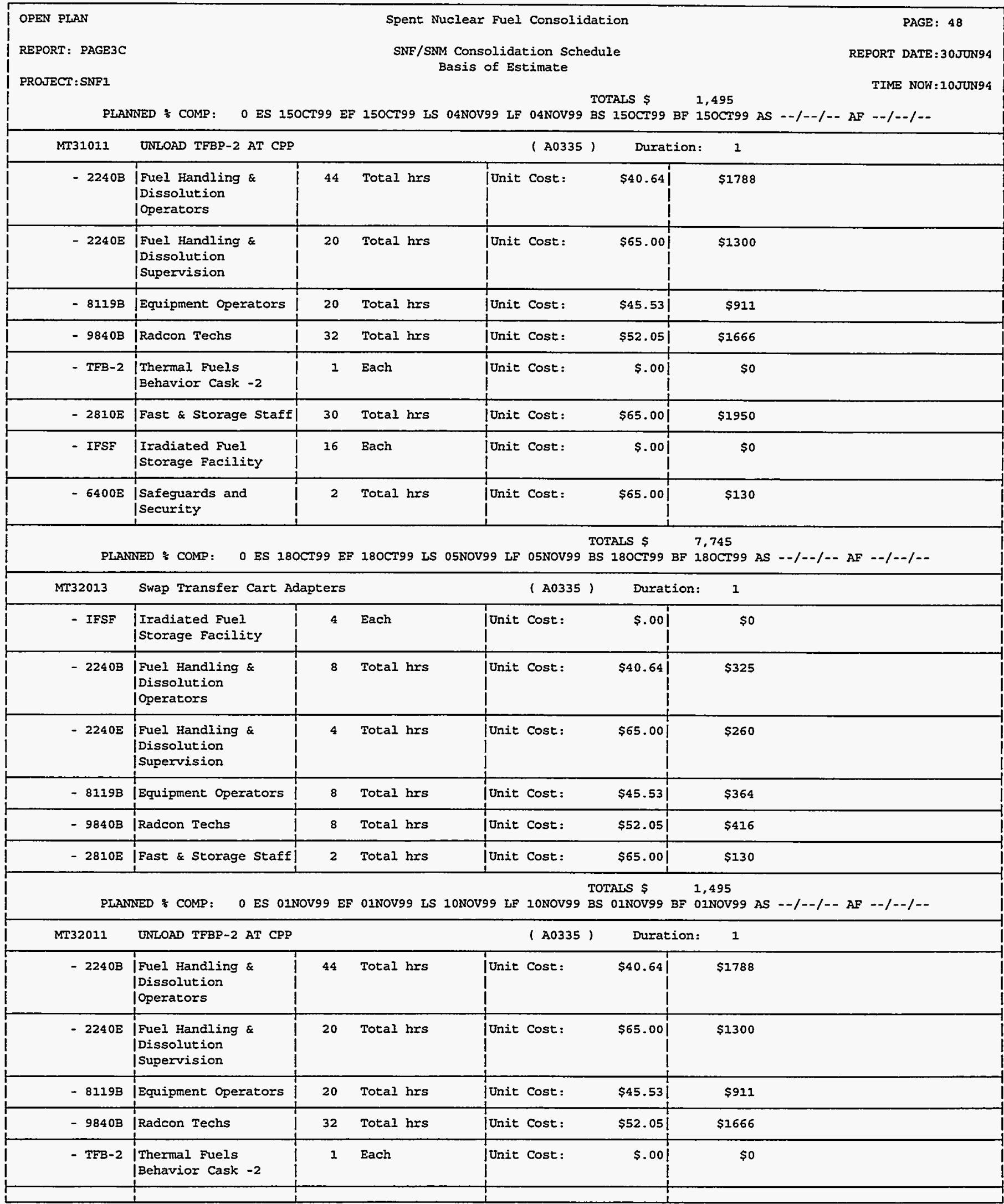




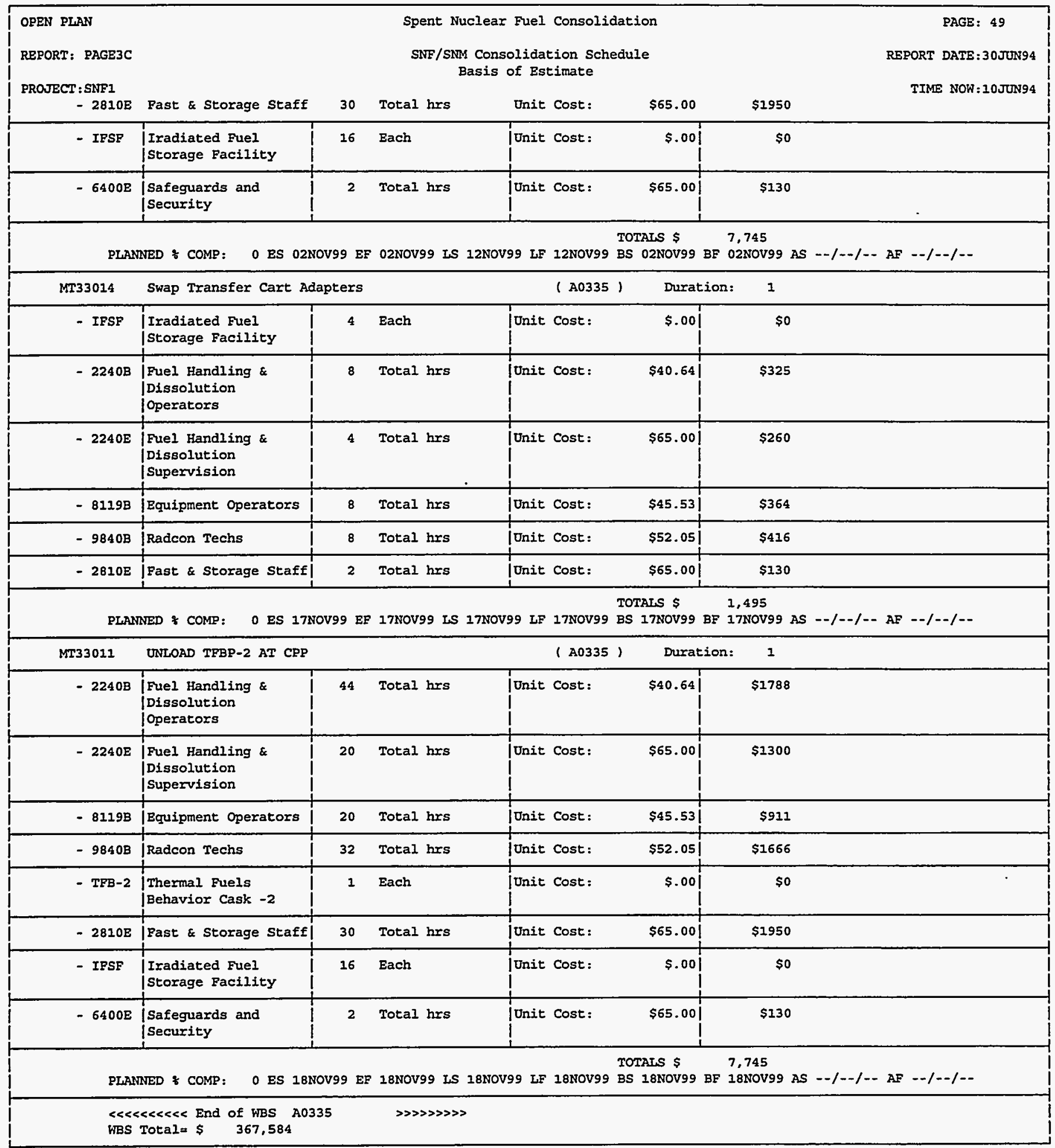




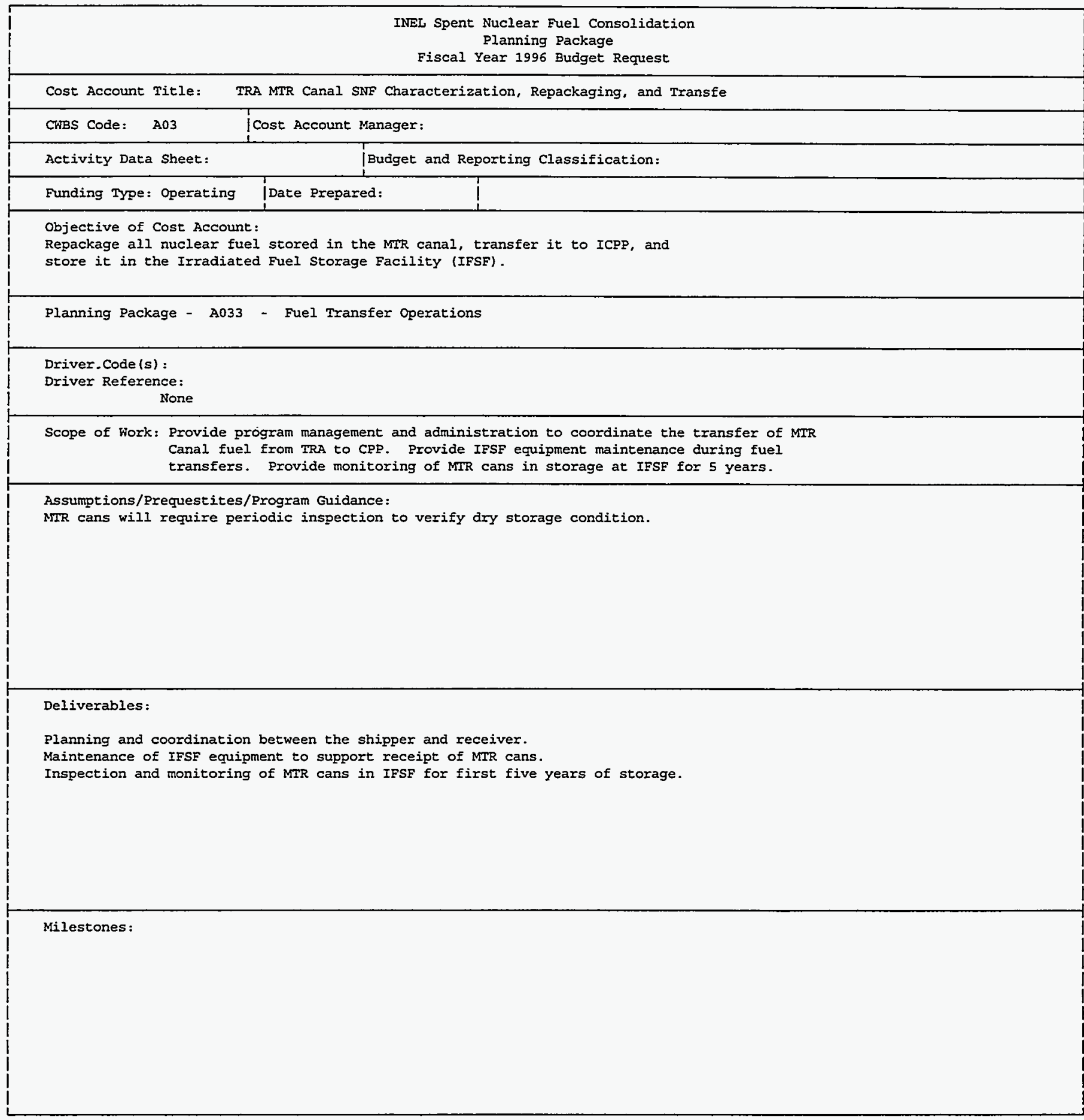




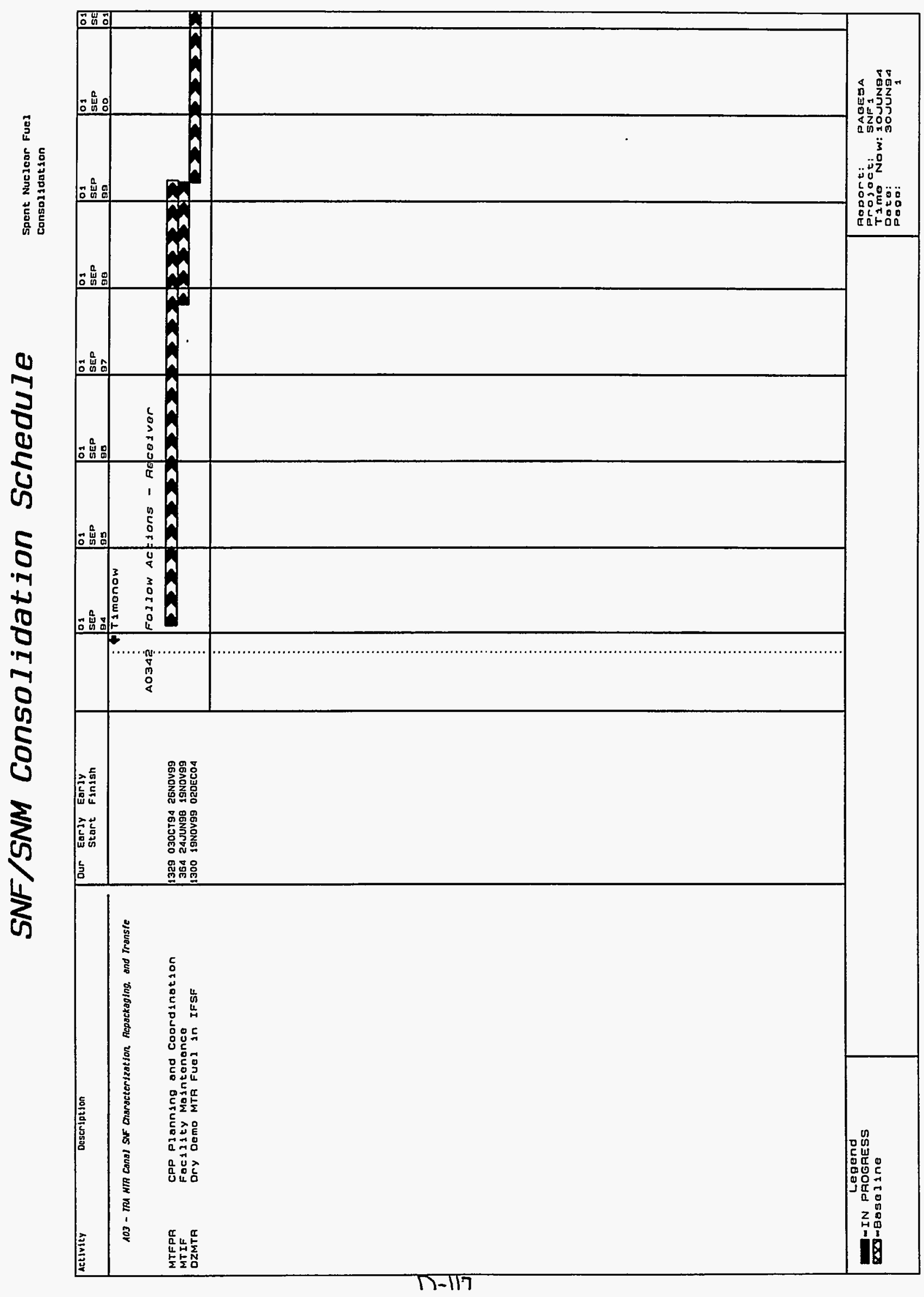




\begin{tabular}{|c|c|c|c|c|c|}
\hline \multicolumn{2}{|c|}{$\begin{array}{l}\text { OPEN PLAN } \\
\text { REPORT: PAGE3C } \\
\text { PROJECT: SNF1 }\end{array}$} & \multicolumn{3}{|c|}{$\begin{array}{l}\text { Spent Nuclear Fuel Consolidation } \\
\text { SNF/SNM Consolidation Schedule } \\
\text { Basis of Estimate }\end{array}$} & $\begin{array}{c}\text { PAGE : } 1 \\
\text { REPORT DATE : } 30 \text { JUN94 } \\
\text { TIME NOW: } 10 \text { JUN94 }\end{array}$ \\
\hline \multicolumn{6}{|c|}{ A03 - TRA MTR Canal SNF Characterization, Repackaging, and Transfe } \\
\hline WBS & DESCRIPTION & $\begin{array}{r}\text { START } \\
\text { DATE }\end{array}$ & $\begin{array}{c}\text { FINISH } \\
\text { DATE }\end{array}$ & $\cos \mathrm{T}$ & \\
\hline A0342 & Follow Actions - Receiver & $030 \mathrm{0T} 94$ & $02 \mathrm{DECO} 4$ & Planning Package $=$ & $\$ 1,553,729$ \\
\hline \multicolumn{4}{|c|}{ A034 } & Cost: & $\$ 1,553,729$ \\
\hline \multicolumn{4}{|l|}{$\mathrm{A} 03-$} & Project Cost: & $\$ \quad 1,553,729$ \\
\hline
\end{tabular}

$\frac{O}{\bar{a}}$ 


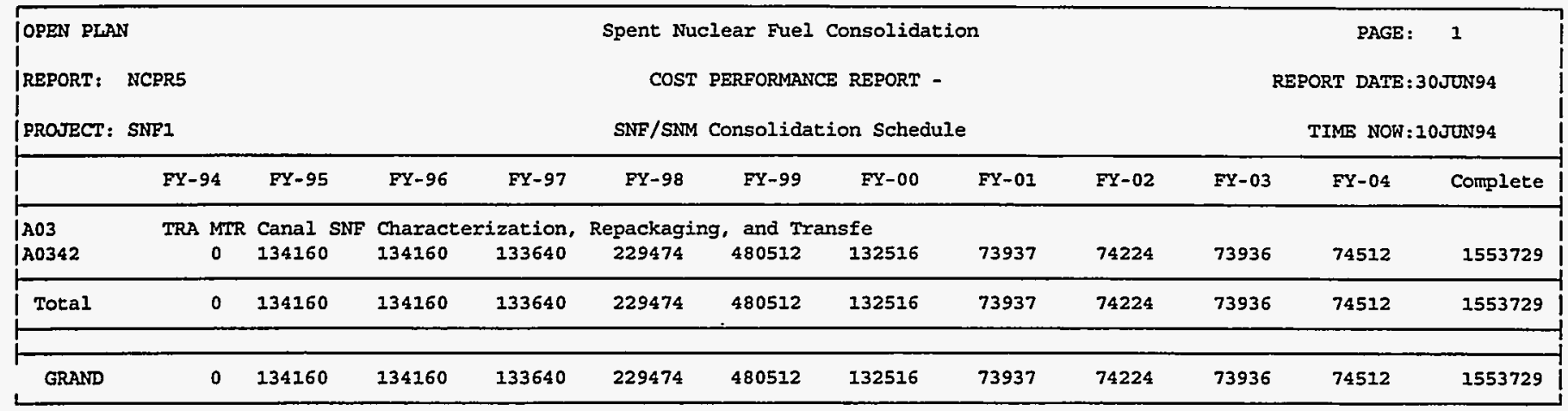




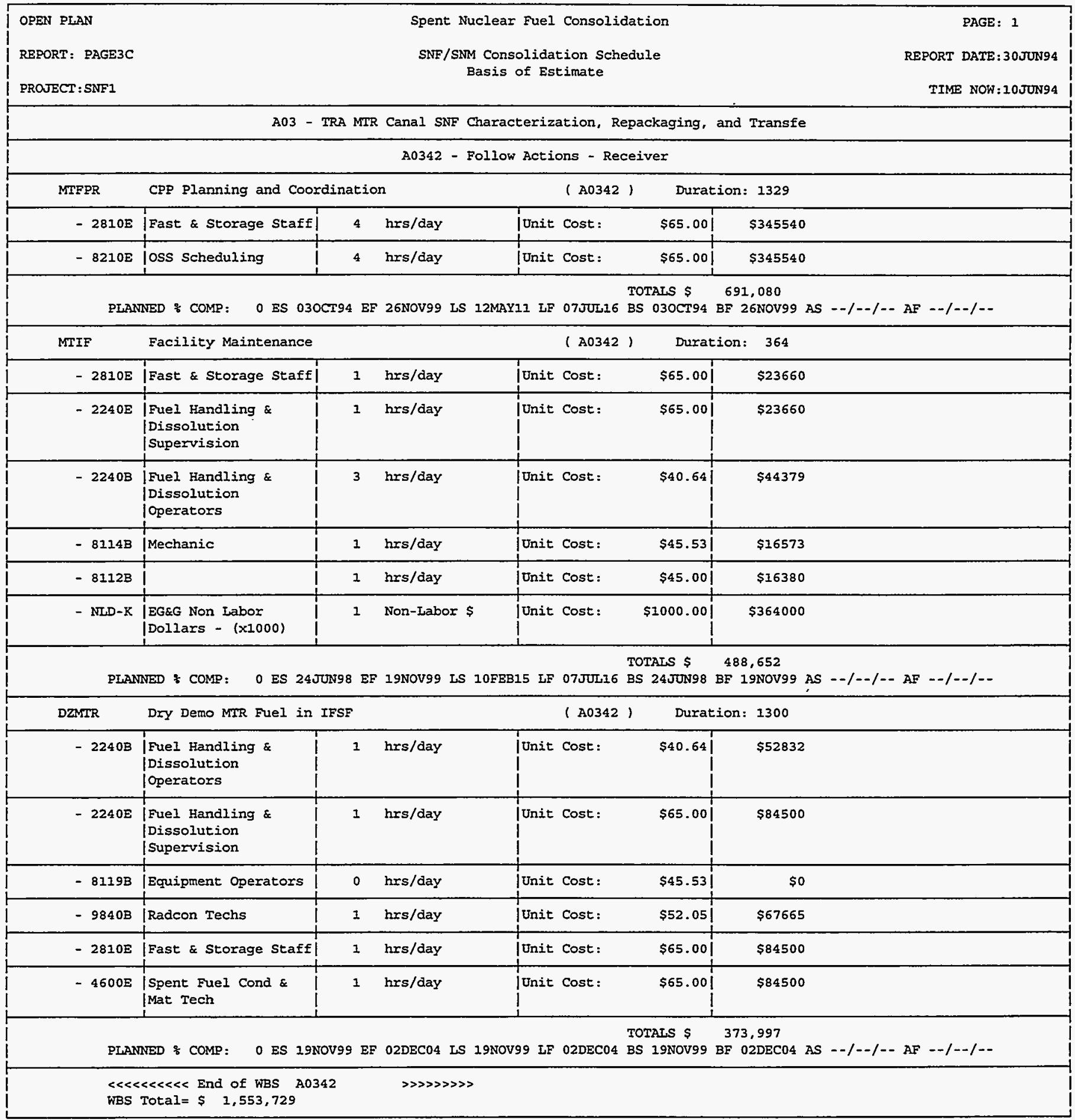


Appendix E

SNF or SNM TRANSFERS TECHNICAL TASKS

This section discusses the processes that will be used to transfer Spent Nuclear Material (SNF) or Special Nuclear Material (SNM) from various Idaho National Engineering Laboratory (INEL) facilities to (ICPP). A considerable amount of preparation is required by the shipper and receiver for each transfer. Routine and less frequent SNF transfers have been safely performed over many years at the INEL. These proven SNF and SNM transport methods will be used for the INEL SNF identified in this consolidation plan. The following subsections provide additional information for each of these transfers.

\section{E.1 PBF Canal SNF Transfer To ICPP IFSF}

The Power Burst Facility (PBF) tested nuclear fuel under severe operating conditions. Figure E-1 shows the general arrangement of the main floor of the reactor building. In the past, irradiated test assemblies were removed from the facility using the Thermal Fuel Behavior Program Number-2 (TFBP-2) cask. The TFBP-2 will be used to transfer SNF to the ICPP. (A description of the TFBP-2 cask is in section 4.2.2.2). Figure E-2 shows the cask in the north end of the facility.

PBF SNF is stored in two temporary fuel storage racks located in the south end of the PBF canal. The SNF consists of stainless steel-clad pins that are bolted into aluminum canister assemblies. Loading procedures for PBF SNF wi11 be developed in detail as part of the transfer project. The assemblies will be placed into the existing PBF Turnover Fixture and the pins will be removed. About 75 pins will be placed into a transport/storage basket, loaded into the TFBP-2 cask, and shipped to the Irradiated Fuel Storage Facility (IFSF) at ICPP.

Major elements of loading the cask will include the following steps. The transporter with the lower cask and 1 id will be backed into the PBF. The cask will be removed from the transporter with the facility 15-ton crane as shown in Figure E-3. The crane will move the cask to the south end of the pool and lower it into the pool. The lower cask door will be opened, and the cask hoist cable will be lowered through a port in the 1id. After the cable is attached to the transport/storage basket, the basket will be raised into the cask, and the lower door closed. The cask will be drained. The cable will then be disconnected from the basket and the port in the lid closed. The cask will then be removed from the poot, decontaminated, and returned to the transporter. With the completion of the appropriate radiological surveys and shipping documentation, the cask will be ready for transport to ICPP.

The cask will be transported to ICPP during daylight hours at 5 to $15 \mathrm{mph}$. The transfer will be timed so it does not occur during peak traffic. Escort vehicles will be located in front of and behind the truck. A similar procedure has proven safe in the past.

At the ICPP, the cask transporter will be surveyed for radiation and then accepted by the facility. Prior to transferring the cask to the transfer cart, an adapter plate configured for the TFBP-2 cask will be placed in the 


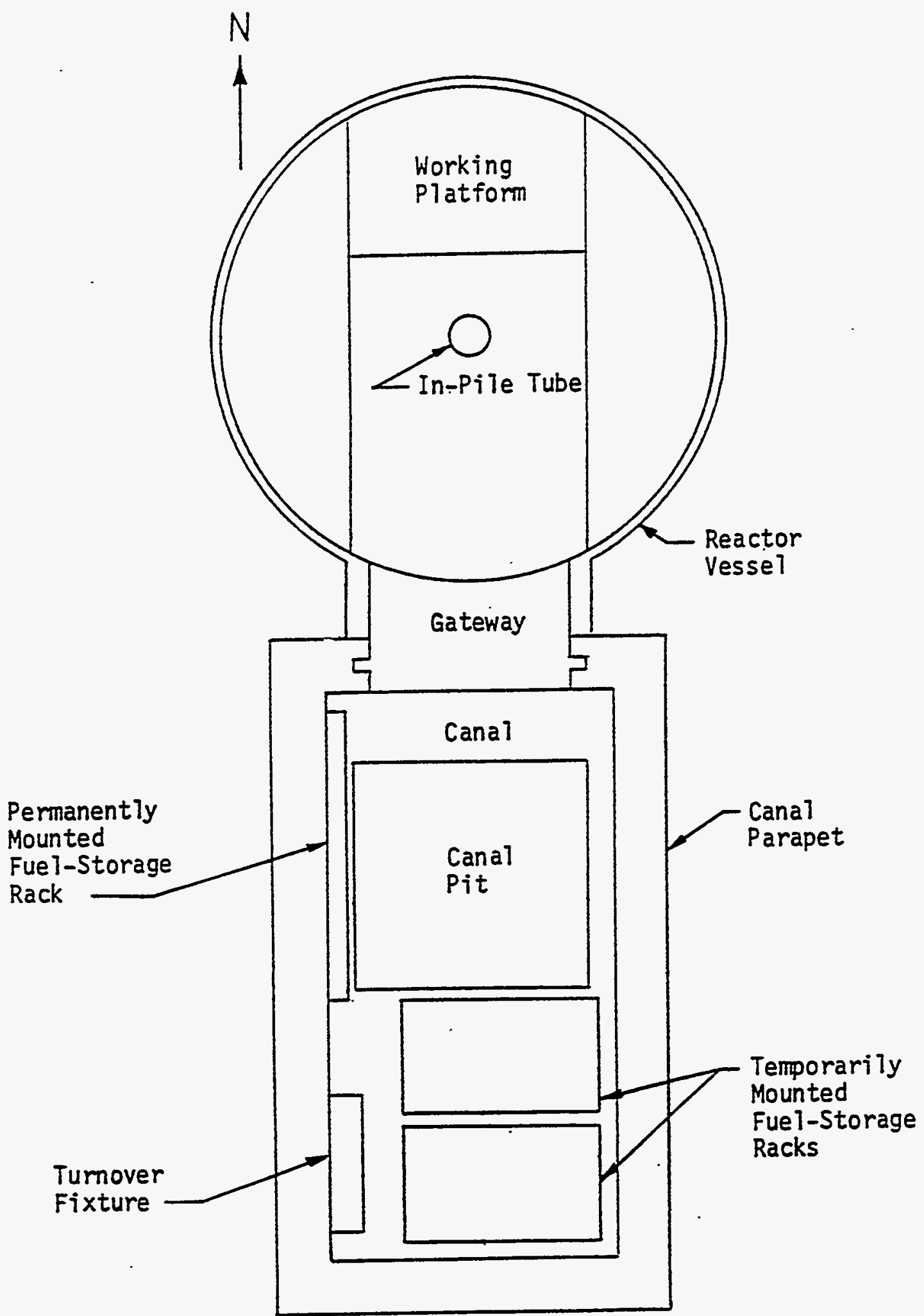

Figure E-1 Top View of PBF Reactor Vessel and Canal 


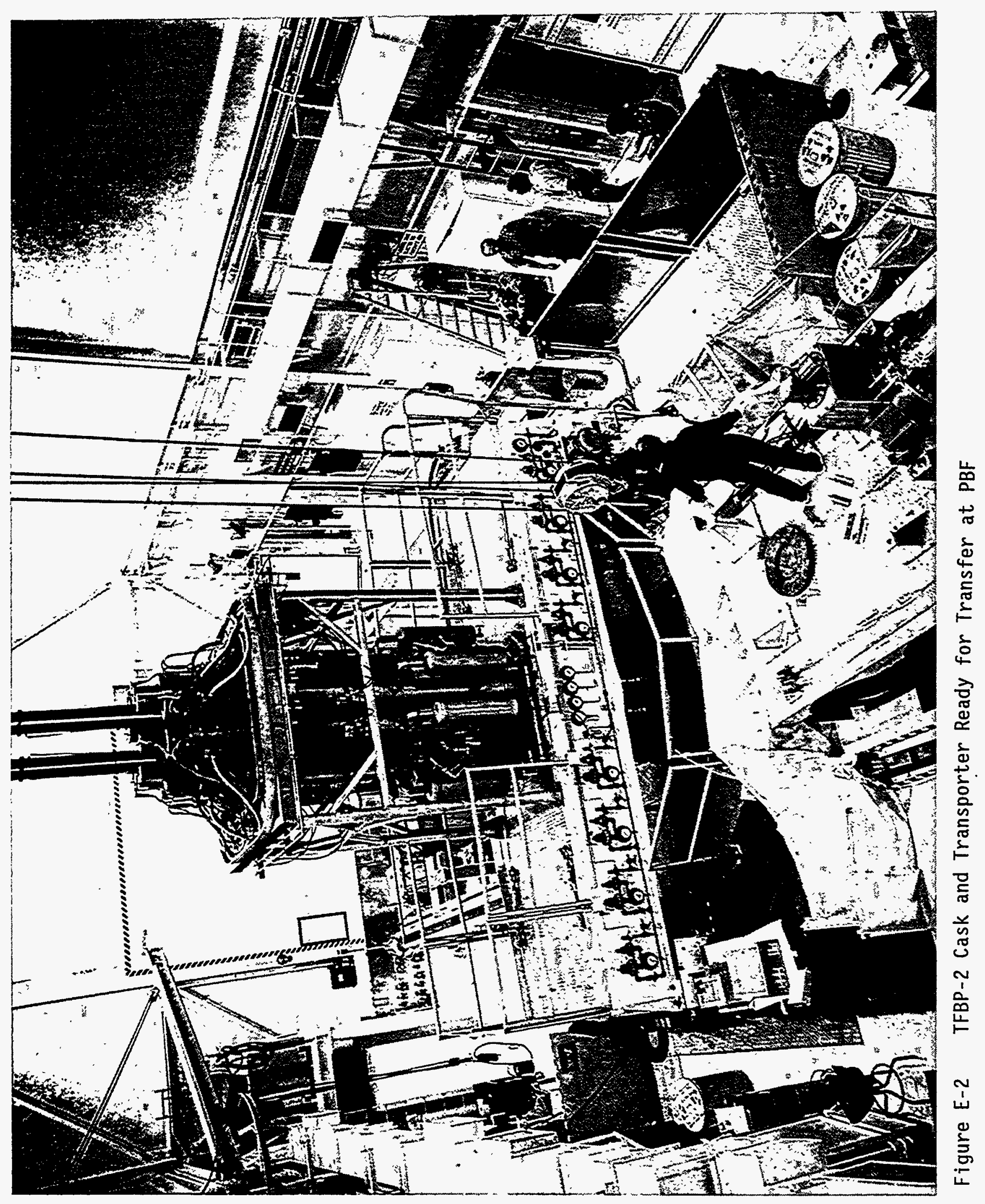

INEL Integrated SNF

12 September 1994

Consolidation Task Team Report 


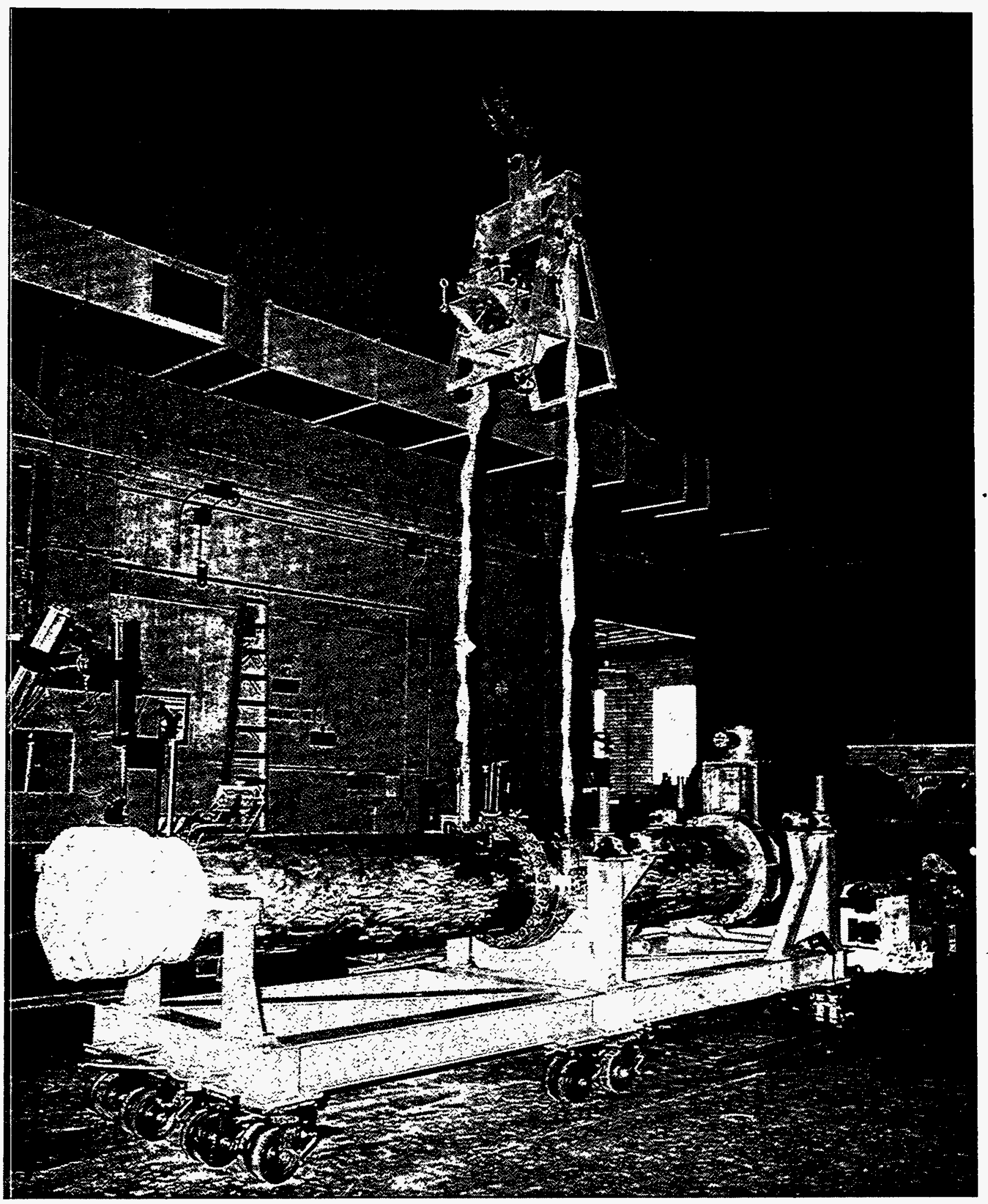

Figure E-3 A Crane Removes The Fut7y Assembled TFBP-2 Cask From The Transporter 
IFSF cart. The cask will then be moved to the IFSF where the cask will be removed from the transporter. The cask will be loaded into the IFSF transfer cart. The lid bolts will be loosened, the majority of them removed, and the rigging will be attached to the lid.

The cask will then be moved into the IFSF shielded area where the 1 id will be remotely removed. Loaded PBF SNF canisters wil7 be remotely removed from the cask and placed into IFSF storage canisters. The storage canisters will then be placed into storage inserts for storage in the IFSF. The cask lid will then be replaced and the cask removed from the IFSF. Lid bolts will be replaced, and the cask returned to the transporter. The cask will be surveyed for radioactive contamination and prepared for empty return to PBF.

\section{E.2 TRA ARMF/CFRMF SNF Transfer To ICPP IFSF}

The Advanced Reactivity Measurement Facility (ARMF) and Coupled Fast Reactivity Measurement Facility (CFRMF) reactors are located in a common pool at TRA-660. Operation of the facility began in the early 1960 s and was stopped in 1991. Figures E-4 shows the layout of the building. The SNF is currently assembled into the reactor core of each reactor. Figure E-5 shows the general arrangement of the ARMF. The CFRMF is similar in design.

Preparations for shipping will begin by disassembly of one reactor system and removal of any interfering equipment.

The TFBP-2 cask will be brought horizontally through the facility roll-up door on an existing dol7y. The cask will be rotated to the vertical position and placed upon the floor. The cask bolts and 1 id will be removed and the cask lowered to the bottom of the reactor pool. Four SNF elements will be transferred to the cask and the 7 id will be replaced on the cask. The cask will then be lifted out of the water and drained. Once drained, the cask can then be placed on the floor. The lid bolts will be installed and the cask decontaminated for shipment. After replacing the cask in the dolly, the cask is moved outside the building and returned to the transporter.

Transport of the SNF to ICPP will be in accordance with an approved transport plan similar to the one used for PBF transfers. Unloading SNF at ICPP will also be similar to unloading PBF SNF.

After unloading the first reactor, the second reactor will be disassembled. The SNF will be transferred to ICPP using the same methods used for the first reactor. 


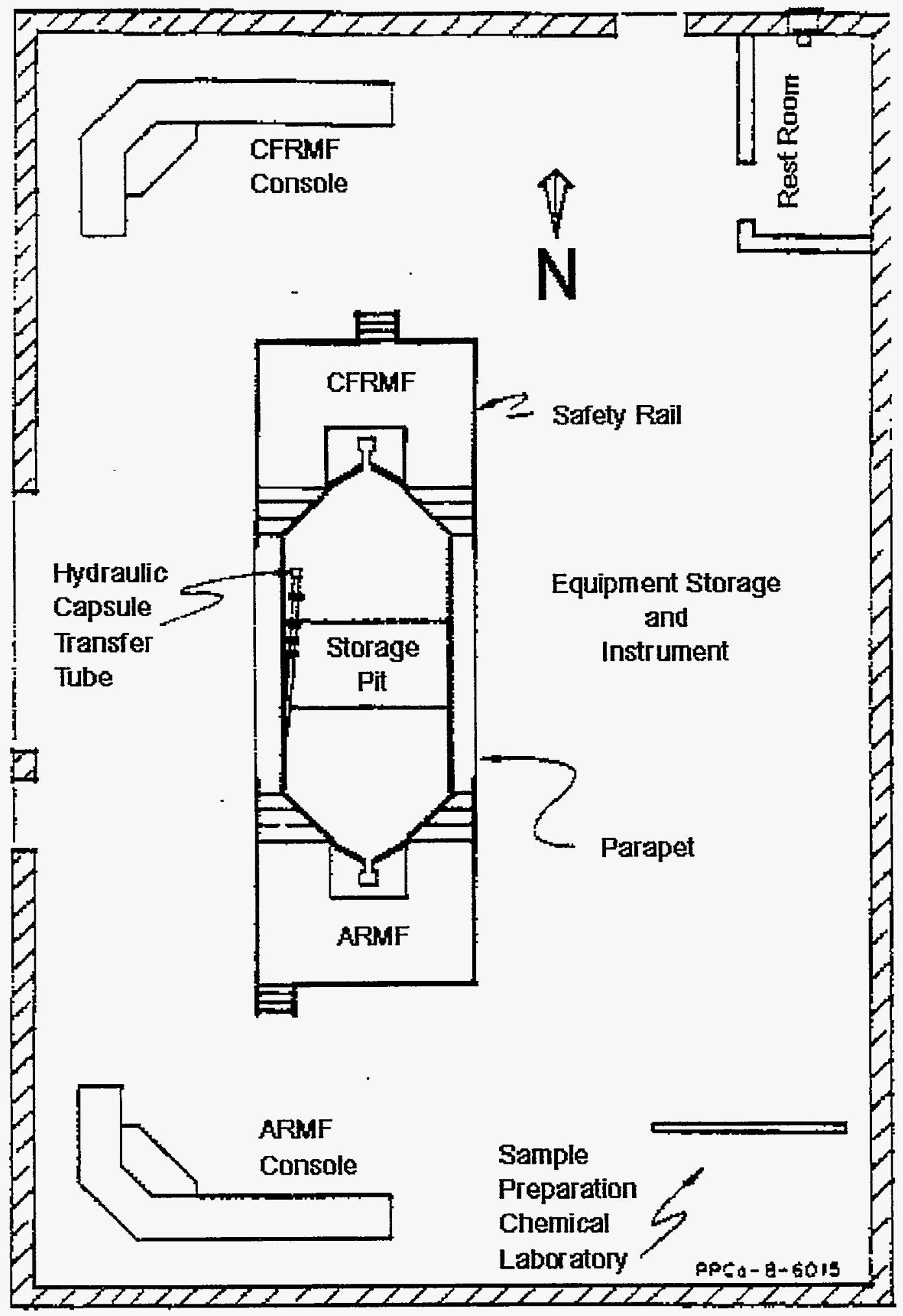

Figure E-4 Layout of ARMF and CFRMF Building 


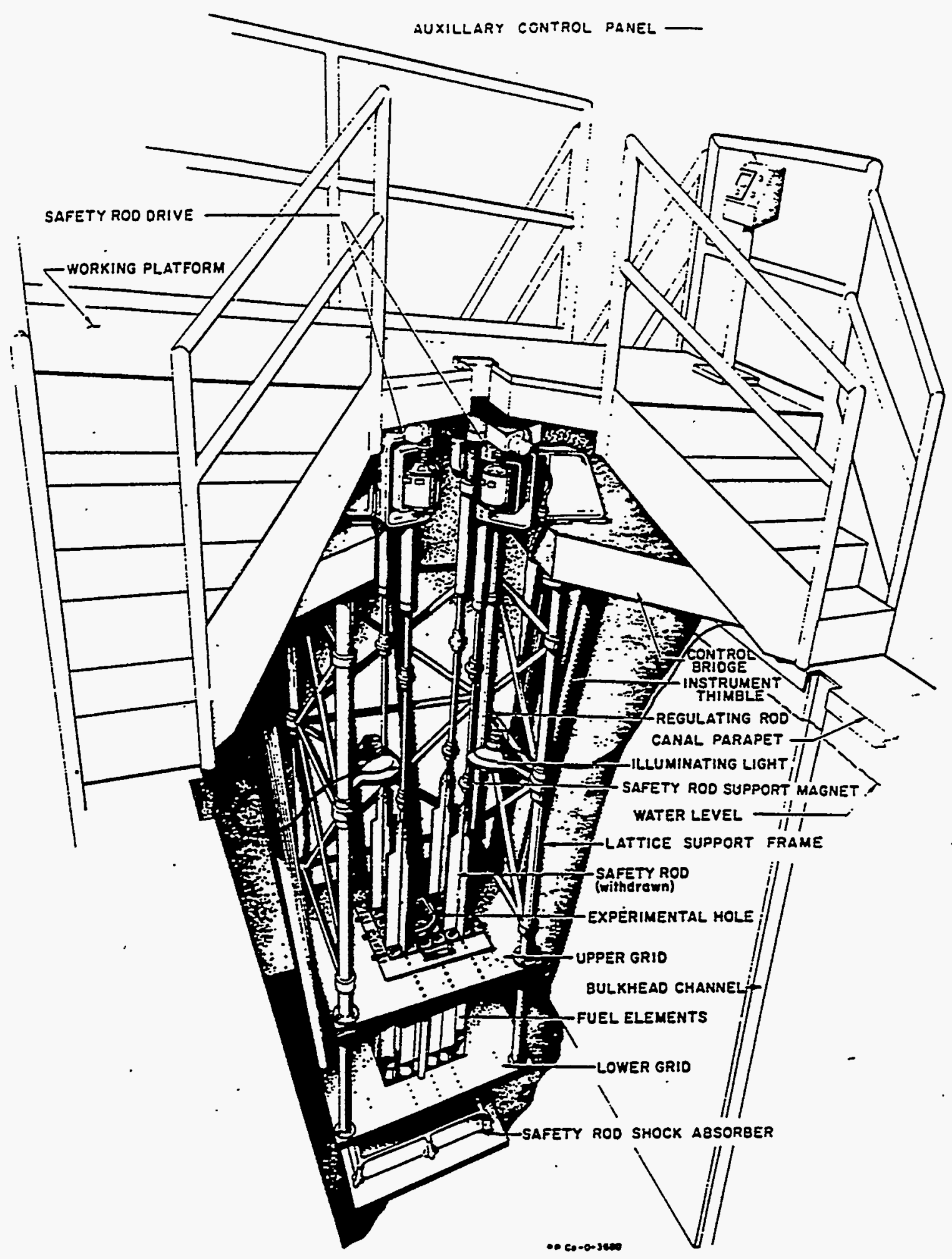

Figure E-5 General Arrangement of ARMF Reactor Structure

INEL Integrated SNF

Consolidation Task Team Report

12 September 1994

NH-CS2. WPD/TC/K:/SP\&I

$E-7$ 


\section{E.3 TRA MTR Canal SNF Characterization, Repackaging, and Transfer to IFSF}

The MTR canal SNF transfer discussion is included as an example in section 1.5 .

\section{E.4 TRA NMIS SNM Transfer to CPP-651}

SNM is stored in the Nuclear Material Inspection \& Storage (NMIS) facility, TRA 621, shown in Figure E-6. This facility is a Material Access Area and contains the activities of non-destructive assay and quality assurance of unirradiated fuel, and storage of SNM. The Category I quantity of SNM is in the form of Advanced Test Reactor (ATR), Engineering Test Reactor (ETR), and General Electric Test Reactor (GETR) unirradiated fuel elements. Category IV quantities are also stored in the form of unirradiated fuel pellets, powders, and PBF unirradiated fuel elements. The ETR and GETR fuel elements have been accepted by the 0ak Ridge Y-12 plant as scrap material, and await transfer offsite. The offsite transfer is currently unfunded; thus, consolidation of this material in CPP-651 is included in this plan.

Approximately 60 transfers of NMIS SNM are anticipated. They will be completed using existing transfer packages (ATR shipping boxes, ETR shipping boxes, and shipping drums) and transport vehicles. A Shipper/Receiver plan will be estab7ished in accordance with DOE Order 5633.3A. At no time will the SNM being transported exceed a Category II quantity. Physical security measures will be maintained and observed throughout the transfer as described in existing safeguards and security procedures.

SNM transfers between TRA and ICPP (approximately 2 miles) will be made entirely within the boundaries of the INEL on INEL roadways. Because the transfers will not use state or public roadways, non-U.S. Department of Transportation certified containers may be used. The current7y uncertified ETR shipping containers, with only a minimum amount of refurbishment, may be used for transferring the ETR and GETR fuels to ICPP. The ATR shipping boxes and shipping drums are certified.

SNM will be received at the Unirradiated Fuel Storage Facility, CPP-651. Fue1 will be placed in storage racks in the north vault (Room 107). The configuration will be identical to previously approved spacing and arrangement. The SNM to be stored in drums will be located in the south vault in accordance with currently approved criteria. 


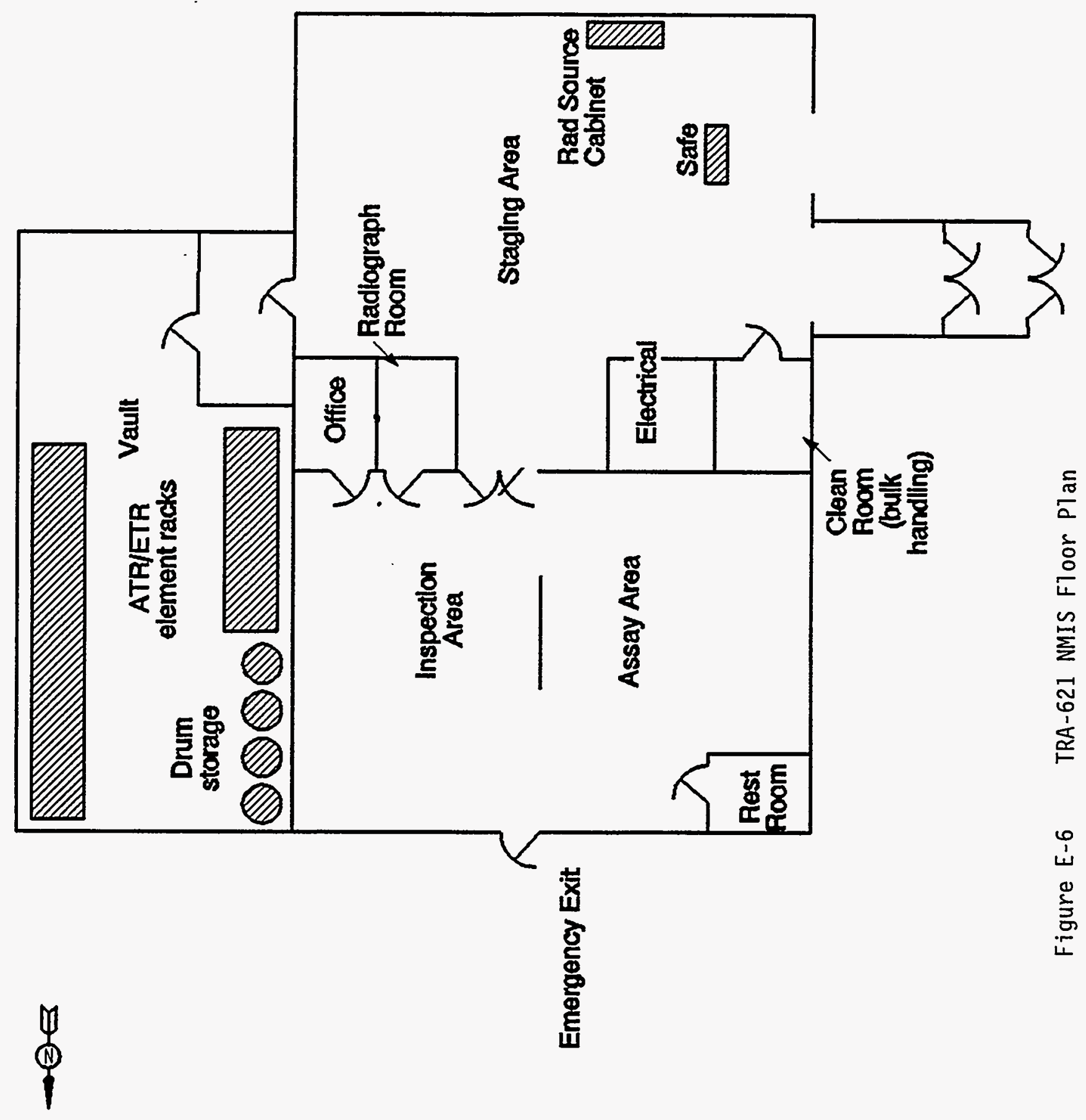




\section{E.5 TAN TMI SNF Transfer TO A New Facility at ICPP}

Figure E-7 shows the TAN-607 facilities. The Three Mile Island (TMI) core debris is stored in stainless steel canisters in storage modules in the TAN Storage Pool. Six canisters are stored in each module. Each canister is currently filled with water and has a vent tube attached to remove any radiolytic gases. DOE recently funded a Line Item Construction Project (LICP) to remove the canisters from the pool and place into dry storage. The original concept of the LICP was to place the canisters into concrete storage casks at Test Area North (TAN). However, present planning is directed to transfer and storage of the canisters at ICPP in dry storage instead.

Individual storage canisters will be retrieved from the Storage Pool with the existing pool bridge crane and transfer cart. The canisters will be drained, dried, and remotely loaded into the Nuclear Packaging (NuPac) 125-B cask in the TAN Hot Shop for transport to ICPP.

The NuPac 125-B cask was designed as a rail cask to transport the canisters from TMI to the Central Facility Area (CFA). A truck trailer transport was used from CFA to TAN-607. To transport the canisters to ICPP, the cask wi1] again be used with a truck trailer. The transporter and cask will be backed into the adjacent TAN-607 Warm Shop. Two 6-ton overpacks will be removed. The transporter will then be moved to the Hot Shop. The cask will be removed from the transporter and placed in the existing cask support stand. The transporter is then removed from the Hot Shop. The cask is opened and prepared for loading. Personnel are then evacuated from the Hot Shop in preparation for remote operations, and seven canisters are loaded into the cask. Both 1 ids will be replaced and the cask leak checked. The transporter will then be returned to the Hot Shop, the cask reloaded, and moved to the Warm Shop for replacement of the overpacks.

The NuPac 125-B cask meets requirements for a U.S. Department of Transportation (DOT)/Nuclear Regulatory Commission (NRC) 1 icensed package. Therefore, the cask can be shipped on the state highway without a special transport plan. However, regulations concerning oversized shipments need to be considered when developing a transport scenario. Current plans are to ship the cask without escorts at highway speeds. The new TMI SNF storage facility at ICPP has not been finalized, but see section 4.1 .4 for a discussion of the current proposed structure.

After unloading, the empty cask and skid will be replaced on the transporter, the overpacks reinstalled, and the cask shipped to TAN for another load. The number of casks used for TMI shipping is dependant upon the number of transporters purchased. 


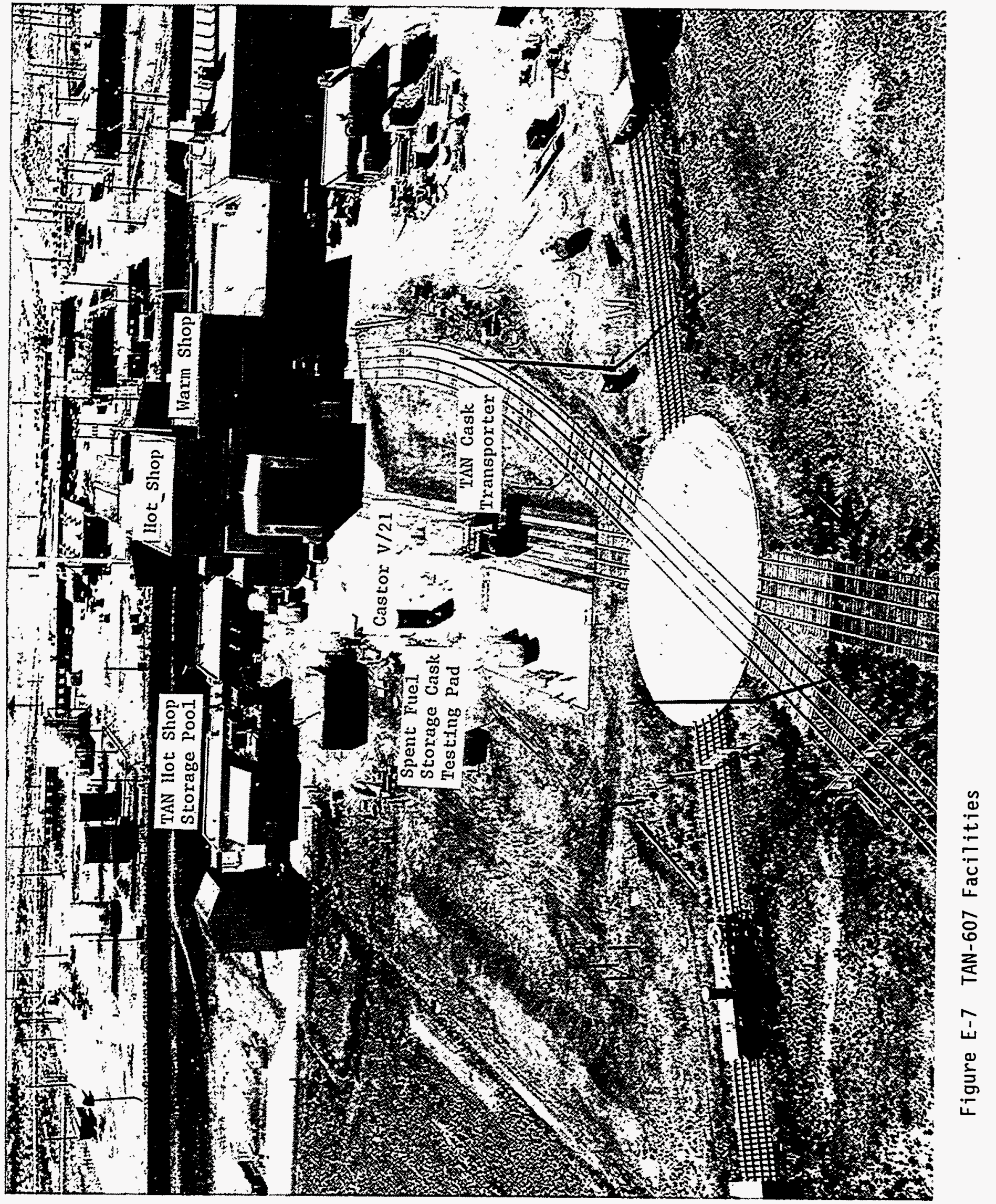

INEL Integrated SNF

12 September 1994

Consolidation Task Team Report 


\section{E.6 TAN LOFT SNF Transfer To CPP-749}

SNF assemblies from the Loss-of-Fluid Test (LOFT) reactor are located in storage modules in the TAN Hot Shop Storage Pool. The modules are predominantly stainless steel and are modifications of modules used to store the TMI core debris. The modules are retrieved into the Hot Shop using the Storage Pool bridge crane and transfer cart. Individual assemblies are removed from the module and placed into equipment to remove the upper structure, any control rod assemblies, a lone neutron source assembly. The removed upper structure and nonfuel components wi 11 be used for salvage, as slight7y contaminated structural material, or transferred to a proper radioactive waste repository disposal. The remaining part of the assembly will be placed into an approved storage canister. A second assembly bottom will be placed into the canister. The canister will be closed and sealed. Canisters will be stored until a cask is available for transfer.

Canisters of LOFT SNF will be transferred to ICPP in the Peach Bottom (PB-2) cask. A trailer with the empty PB-2 cask will be backed into the Hot Shop. The cask will be removed from the trailer and placed into the existing cask stand. The trailer will then be removed from the Hot Shop. The cask lid bolts will be removed. The 7 id will be removed and rigged for remote installation. Then, personnel will leave the Hot Shop preparatory to remote operations. The canister will be retrieved from the storage location and placed into the cask. The cask 1 id will be remotely replaced on the cask. Personnel can then enter the Hot Shop to install the lid bolts and check the cask for contamination. The trailer will be returned to the Hot Shop, and the cask will be installed on the trailer. The transporter will be removed from the Hot Shop and prepared for transfer to ICPP.

The road between TAN and ICPP is within the controlled area of the INEL. However, a five-mile section of the road is also a state highway. A further shipping complication is that the PB-2 cask is not licensed by the NRC for transport of radioactive materials in commerce. One method for meeting the DOT regulations is to obtain a DOT exemption. This is a procedure within the Code of Federal Regulations that uses administrative controls for equivalent safety, as approved by DOT.

Another method for shipping the PB-2 cask is to make the transfers "out-ofcommerce." This is another allowable procedure using DOE equipment and personne1.

A third method is to request permission from the State of Idaho to close the highway during the time (about one-hour) required to traverse that section of highway. Road closure could be performed by State of Idaho State Police. The cask would be moved at 5 to 15 miles per hour. Escort vehicles would be provided both ahead of and behind the transporter for traffic control. Normal traffic would resume when the transporter left the state highway.

The cask and transporter will be surveyed for radioactivity when it is received at ICPP. The transporter will be delivered to CPP-749 and the cask removed. The cask will be placed over the storage we 11 iner in CPP-749 and the bottom of the cask opened. The storage canister will be lowered into the well through the bottom of the PB-2 cask. The canister will be released and the cask returned to the transporter. The cask will be returned to TAN. A total of 7 transfers of the LOFT fuel to CPP-749 storage will be made. 


\section{E.7 TAN Commercial SNF Transfer to New Pad at ICPP}

Commercial SNF is stored at TAN in two locations. Most of the SNF is stored in four dry storage casks located on the Spent Fuel Storage Cask Testing Pad (TAN-791) outside the TAN-607 Hot Shop. The casks, MC-10, TN-24P, VSC-17 and Castor V-21, are a long-term, temporary storage demonstration of SNF from Pressurized Water Reactors. The remaining commercial SNF is in the TAN Pool in aluminum storage boxes (also called coffins). Plans are to relocate this SNF to the Hot Shop silo in FY-95 to remove an existing environmental, safety, and health (ES\&H) vulnerability, i.e., potential corrosion of the aluminum boxes.

Commercial SNF consolidation begins with moving the MC-10 from the storage pad into the Hot Shop using the existing TAN cask transporter. Lid bolts will be removed from the cask, the Hot Shop evacuated, and the lid remotely removed from the cask. SNF stored in the silo will then be remotely transferred to the cask, and the cask 1 id will be remotely returned to the cask.

Another task in consolidation of TAN Commercial SNF will require emptying the VSC-17 cask. This cask is concrete and cannot be handled at ICPP using existing facilities. The VSC-17 and the TN-24P wi1l be moved into the Hot Shop using the existing TAN cask transporter. The lids of both casks will be opened and the SNF transferred from VSC-17 to the TN-24P cask. The 1id will then be replaced on the TN-24P, and the casks will be removed from the Hot Shop. The VSC-17 can then be discarded.

Plans are to move the three casks from TAN to a new concrete pad next to CPP-749. Three alternative methods are being considered for this move. One method is to transport the casks on the transporter used for the NuPac 125-B. The casks will be moved into the TAN Hot Shop and placed horizontally on the transporter. Because none of the casks are 1jcensed for shipment in commerce, the transporter would be escorted to ICPP similar to transport of LOFT SNF, i.e., most likely out-of-commerce transfers. The casks would then be rotated to the vertical position and removed from the transporter using a new bridge crane in the vault system being planned for TMI canisters storage. The TAN cask transporter would be moved to ICPP from TAN and used to move the casks to the new pad.

The last option considered would be to unload the casks at TAN and transfer empty storage casks to CPP-666. The SNF would then be transferred to CPP-666 in the TN-8L commercial SNF transport cask, and loaded under water into the storage cask. The storage cask would be 7 ifted out of the water, drained, backfilled with an inert gas, and transferred to a storage pad near CPP-749. This wet unloading interface would complicate, if not negate, completion of any additional long-term dry storage demonstration program for these commercial spent fuels. This Spent Fuel Behavior Program is currently sponsored by DOE RW. 